\title{
BIBLIOGRAPHY, INDEX, AND DATA SOURCES \\ FOR GROUND-WATER HYDROLOGY AND \\ GEOLOGY OF COLORADO WEST OF THE \\ CONTINENTAL DIVIDE
}

By Edward R. Banta and Theresa Jo Lane

U.S. GEOLOGICAL SURVEY

Open-File Report 92-79

Prepared in cooperation with the

COLORADO WATER CONSERVATION BOARD

Denver, Colorado

1992 


\section{U.S. DEPARTMENT OF THE INTERIOR \\ MANUEL LUJAN, JR., Secretary}

U.S. GEOLOGICAL SURVEY

Dallas L. Peck, Director

For additional information write to:

\section{District Chief}

U.S. Geological Survey

Box 25046, Mail Stop 415

Denver Federal Center

Denver, CO 80225-0046
Copies of this report can

be purchased from:

U.S. Geological Survey

Books and Open-File Reports Section

Federal Center

Box 25425

Denver, CO 80225 
CONTENTS

Page

Abstract-1

Introduction-1

Bibliography-_. 7

Subject index- 124

TABLE

Table 1. Sources of geohydrologic and geologic data for wells and test

Page

holes in western Colorado- 


\title{
BIBLIOGRAPHY, INDEX, AND DATA SOURCES FOR GROUND-WATER HYDROLOGY AND GEOLOGY OF COLORADO WEST OF THE CONTINENTAL DIVIDE
}

By Edward R. Banta and Theresa Jo Lane

\begin{abstract}
The potential for development of the ground-water resources in Colorado west of the Continental Divide is great; however, sources of data concerning the geohydrology of the area are disorganized and scattered. This report presents a bibliography, an index, and sources of available data about the ground-water hydrology and geology of Colorado west of the Continental Divide. Interpretive reports, data reports, and geologic maps dated 1871 through 1989 are referenced and indexed. Sources of site-specific data from wells and test holes are tabulated.
\end{abstract}

\section{INTRODUCTION}

Ground-water resources in Colorado west of the Continental Divide have not been used extensively because of the general abundance of surface water and because of a lack of knowledge about the aquifer systems in the area. However, the potential for development of the ground-water resources in western Colorado is great. To effectively develop, administer, and manage these potential resources, Federal, State, and other agencies need to use all available data concerning the geohydrology of Colorado west of the Continental Divide, but sources of these data are disorganized and scattered. In 1989, the U.S. Geological Survey, in cooperation with the Colorado Water Conservation Board, began to identify, reference, and index the sources of geohydrologic data for western Colorado to establish a central source of information for use by ground-water hydrologists.

This report presents a bibliography, an index, and sources of the available data about the ground-water hydrology and geology of Colorado west of the Continental Divide. Interpretive reports, data reports, and geologic maps are referenced in the bibliography section. The bibliography is intended to be comprehensive for 1871 , the date of the earliest report referenced, through 1989. These publications are indexed by county, technical content, geohydrologic unit, and selected descriptors in the index section. Numbers following the index entries refer to numbers assigned to each reference in the bibliography section. Some reference numbers intentionally have been skipped as a result of deletion of duplicate references. References that are oriented toward ground-water hydrology were scanned to determine the types of tabulated data and maps available in each. These are referenced in indented sub-indexes 
under county, descriptor, and geohydrologic-unit entries in the index; references to reports containing thematic maps are listed under the index entry: "Maps, by geohydrologic unit and theme." Extensive efforts have been made to ensure that all citations in this bibliography are correct. However, not all references could be verified; as a result, some citations may contain errors or may be incomplete. Entries in the index were derived from publication titles, from other bibliographies (references 16, 17, 18, 19, and 1287), and from scanning the publications oriented toward ground-water hydrology. Where index entries include sub-index entries, the sub-index entries were determined by intersection of the sets of references for which the main index entry and the sub-index entry apply individually. This approach produces a thoroughly indexed bibliography, but one which should be used with awareness of the method used to produce it. For example, a report that discusses several geohydrologic units and includes aquifer-test results for some, but not all, of those units will be listed under "Aquifer tests" under each of the geohydrologic units discussed, even though aquifer-test results are not included in the report for all geohydrologic units discussed in the report.

Sources of site-specific data from wells and test holes are listed in table 1. Those sources include Federal and State agencies and private firms. The wells and test holes from which the data were obtained were drilled to be water-, oil-, or gas-withdrawal wells, monitoring wells, or oil, gas, or mineral test holes.

The authors thank Jerry Blair of American Stratigraphic Company; Richard Anderson of Anderson Stratigraphic and Geologist Service; Robert Quillin, Jeff Deckler, and George Moravec of the Colorado Department of Health; Carol Tremain of the Colorado Department of Natural Resources, Geological Survey; Berhan Keffelew and James Pendleton of the Colorado Department of Natural Resources, Mined Land Reclamation Division; James Kenney of the Colorado Department of Natural Resources, $\mathrm{Oil}$ and Gas Conservation Commission; George Van Slyke of the Colorado Department of Natural Resources, Division of Water Resources; Brandy Gilmore of the Colorado Highway Department; Joseph Kulik of Denver Earth Resources Library; Lawrence Sanek of MJ Systems; William Werrell of the National Park Service; Mark Chase of Petroleum Information; George Knoll of the Southern Ute Indian Reservation, Natural Resources Division; Steve Manydeeds of the U.S. Bureau of Indian Affairs; Fred Conrath, Bruce Fowler, and Kent Hoffman of the U.S. Bureau of Land Management; Karl Starch of the U.S. Bureau of Mines; Lynn Johnson of the U.S. Bureau of Reclamation; and Darcy Campbel1, George Dancik, and Pat Smith of the U.S. Environmental Protection Agency for providing information concerning data held by their organizations . 
Table 1.--Sources of geohydrologic and geologic data for wells and test holes in western Colorado

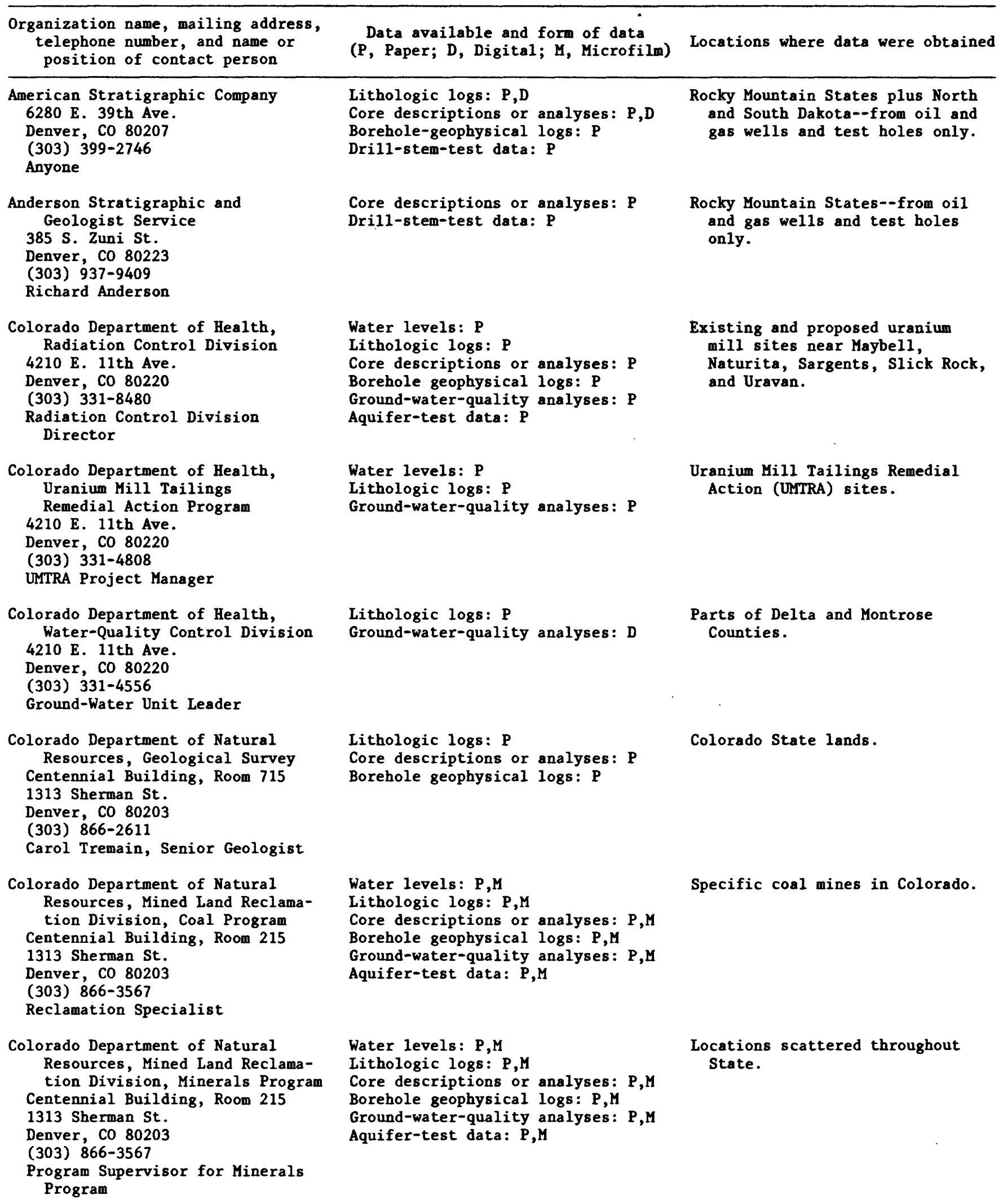


Table 1.--Sources of geohydrologic and geologic data for wells and test holes in western Colorado--Continued

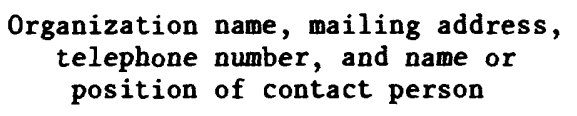

Colorado Department of Natural Resources, 0 il and Gas Conservation Commission Suite 380

1580 Logan St.

Denver, CO 80203

(303) $894-2100$

Senior Engineer

Colorado Department of Natural Resources, Division of Water Resources

Centennial Building, Room 821

1313 Sherman St.

Denver, C0 80203

(303) 866-3447

Records Section

Colorado Highway Department

4340 E. Louisiana Ave.

Denver, CO 80222

(303) 757-9275

Chief Geologist

Denver Earth Resources Library Equitable Building, Suite B-1 73017 th St.

Denver, CO 80202

(303) 825-5614

Manager

MJ Systems

5085 Oakland St.

Denver, C0 80239

(303) 371-1960

Vice President of Domestic Operations

\footnotetext{
National Park Service, Water Resources Division

$301 \mathrm{~S}$. Howes St.

Fort Collins, CO 80521

(303) 221-5341

Chief, Water Resources Division or contact superintendents of individual national parks, monuments, or recreation areas
}

Petroleum Information

P.0. Box 2612

Denver, CO 80201-2612

(303) 825-2299

Senior Sales Representative

Southern Ute Indian Reservation, Natural Resources Division

P.0. Box 737

Ignacio, $\mathrm{CO} 81137$

(303) 563-4525

Chief, Natural Resources Division
Data available and form of data (P, Paper; D, Digital; M, Microfilm)

Lithologic logs: M

Core descriptions or analyses: $M$ Borehole geophysical logs: $M$ Ground-water-quality analyses: $P$ Drill-stem-test data: $M$

Water levels: $P, M$

Lithologic logs: P,M

Borehole geophysical logs: P

Ground-water-quality analyses: $P, M$

Water levels: $P$

Lithologic logs: P

Core descriptions or analyses: $P$

Lithologic logs: P,M

Core descriptions or analyses: $P, M$

Borehole geophysical logs: P,M

Drill-stem-test data: P,M

Lithologic logs: D,M

Core descriptions or analyses: D,M

Borehole geophysical logs: D,M

Drill-stem-test data: D,M

Water levels: $P$

Lithologic logs: P

Borehole geophysical logs: $P$

Ground-water-quality analyses: $P$

Aquifer-test data: $P$

Lithologic logs: P

Core descriptions or analyses: D

Borehole geophysical logs: P

Drill-stem-test data: D

Water levels: $P$

Lithologic logs: P

Ground-water-quality analyses: $P$
Colorado.

Locations where data were obtained Colorado.

Highway rights-of-way in Colorado.

Rocky Mountain States--from oil and gas wells and test holes only.

United States--from oil and gas wells and test holes only.

National parks, national monuments national recreation areas.

United States--from oil and gas wells and test holes only.

Southern Ute Indian Reservation. 
Table 1.--sources of geohydrologic and geologic data for wells and test holes in western Colorado--Continued

Organization name, mailing address,
telephone number, and name or
position of contact person
U.S. Bureau of Indian Affairs,
Division of Energy and Minerals,
Office of Trust Responsibility
Room 239
730 Simms St.
Lakewood, C0 80401
(303) $231-5070$
Division Chief
U.S. Bureau of Land Management,
Craig District Office
455 Emerson St.
Craig, CO 81625
(303) $824-8261$
District Geologist

U.S. Bureau of Land Management, Grand Junction District Office 764 Horizon Drive Grand Junction, CO 81506 (303) 243-6561 Minerals Specialist

U.S. Bureau of Land Management, San Juan Resource Area Office Federal Building

701 Camino Del Rio

Durango, CO 81301

(303) 247-4082

Minerals Staff Chief

U.S. Bureau of Mines, Intermountain Field Operations Center

Building 20

Denver Federal Center

Denver, C0 80225

(303) 236-0474

Librarian

U.S. Bureau of Reclamation, Geohydraulics section Mail Code D5741, Denver Office P.0. Box 25007

Denver, Co 80225

(303) $236-8070$

Head, Geohydraulics Section

U.S. Environmental Protection Agency, Hazardous Waste Management Division Mail Code 8HWM-SM 999 18th St., Suite 500 Denver, CO 80202-2405 (303) 294-7596 Regional Hydrogeologist (Superfund)

U.S. Environmental Protection Agency, Hazardous Waste Management Division 999 18th St., Suite 500 Denver, CO 80202-2405 (303) 293-1506

Environmental Engineer for Colorado/Montana RCRA section
Data available and form of data (P, Paper; D, Digital; M, Microfilm)

Borehole geophysical logs: $M$

Ground-water-quality analyses: $P$

Drill-stem-test data: P,D

Water levels: $P$

Lithologic logs: P

Core descriptions or analyses: $P$

Borehole geophysical logs: M

Ground-water-quality analyses: $P$

Aquifer-test data: $P$

Drill-stem-test data: $P$

Water levels: $P$

Lithologic logs: $P$

Borehole geophysical logs: $M$

Ground-water-quality analyses: $P$

Drill-stem-test data: $P$

Water levels: $P$

Lithologic logs: P,M

Core descriptions or analyses: $P$

Borehole geophysical logs: P,M

Ground-water-quality analyses: $P$

Drill-stem-test data: $P$

Lithologic logs: P

Core descriptions or analyses: $P$

Water levels: $P, D$

Lithologic logs: P,D

Core descriptions or analyses: $P, D$

Borehole geophysical logs: $P, D$

Ground-water-quality analyses: $P, D$

Water levels: $P, D, M$

Lithologic logs: $P, M$

Borehole geophysical logs: P,M

Ground-water-quality analyses: $P, D, M$

Aquifer-test data: $P, D, M$

Water levels: $P$

Lithologic logs: $P$

Ground-water-quality analyses: $P$
Locations where data were obtained

Ute Mountain Indian Reservation and Southern Ute Indian Reservation.

Craig district (Craig-KremmlingMeeker area).

Grand Junction district (Glenwood Springs-Grand Junction area).

Montrose district (DurangoGunnison-Montrose area).

Federal public lands.

Areas close to Bureau projects (dams) and proposed projects along stream systems.

Superfund sites and surrounding areas.

Resource Conservation and Recovery Act (RCRA) sites. 
Table 1.--Sources of geohydrologic and geologic data for wells and test holes in western Colorado--Continued

Organization name, mailing address, telephone number, and name or position of contact person

U.S. Environmental Protection Agency, Hazardous Waste Management Division

999 18th St., Suite 500

Denver, CO 80202-2405

(303) 293-1262

Superfund Site Assessment Manager

U.S. Geological Survey, Water Resources Division, Colorado District office

P.0. Box 25046, Mail Stop 415

Denver, CO 80225-0046

(303) 236-4882

Chief, Hydrogeologic Unit or Chief, Surveillance Section

U.S. Geological Survey, Water Resources Division, Lakewood Field Headquarters P.0. Box 25046, Mail Stop 423 Denver, CO 80225-0046 (303) 236-9404

Chief, Lakewood Field Headquarters
Data available and form of data (P, Paper; D, Digital; M, Microfilm)

Locations where data were obtained

Water levels: $P$

Lithologic logs: $P$

Potential superfund sites.

Water levels: D

Ground-water-quality analyses: D Aquifer-test data: D

\author{
Colorado (National Water \\ Information System files).
}

Water levels: P

Lithologic logs: $P$

Colorado.

Borehole geophysical logs: P

Aquifer-test data: $P$ 


\section{BIBLIOGRAPHY}

1. Abbott, D.M., Jr., 1975, The Precambrian geology of the East Inlet area, southwestern Rocky Mountain National Park, Colorado: Golden, Colorado School of Mines, Master's thesis, $96 \mathrm{p}$.

2. Abrassart, C.P., 1951, Stratigraphy and sedimentation of the Juniper Mountain area, Moffat County, Colorado: Boulder, University of Colorado, Master's thesis, $58 \mathrm{p}$.

3. Abrassart, C.P., and Clough, G.A., 1955, Juniper Mountain area, Colorado, in Ritzma, H.R., and Oriel, S.S., eds., Guidebook to the geology of northwest Colorado, Intermountain Association of Petroleum Geologists, 6th annual field conference, 1955: Salt Lake City, Intermountain Association of Petroleum Geologists, p. 63-70.

4. Ackerman, D.J., and Brooks, T.D., 1985, Ground-water data from the San Miguel River basin, southwestern Colorado: U.S. Geological Survey Open-File Report 85-191, 19 p.

5. Ackerman, D.J., and Brooks, Tom, 1986, Reconnaissance of ground-water resources in the North Fork Gunnison River basin, southwestern Colorado: U.S. Geological Survey Water-Resources Investigations Report 85-4230, $21 \mathrm{p}$.

6. Ackerman, D.J., and Rush, F.E., 1984, Hydrogeologic reconnaissance of the San Miguel River basin, southwestern Colorado: U.S. Geological Survey Water-Resources Investigations Report 84-4133, 25 p.

7. Adams, D.B., Goddard, K.E., Patt, R.0., and Galyean, K.C., 1986, Hydrologic data from Roan Creek and Parachute Creek basins, northwestern Colorado: U.S. Geological Survey Open-File Report 83-859, 115 p.

8. Adams, M.A., and Kirr, J.N., 1984, Geologic overview, coal deposits, and potential methane recovery from coalbeds of the Uinta Basin, Utah and Colorado, in Rightmire, C.T., Eddy, G.E., and Kirr, J.N., eds, Coal bed methane resources of the United States: American Association of Petroleum Geologists Studies in Geology 17, p. 253-269.

9. Adler, F.J., 1960, The Paradox basin of Colorado, chap. 17 of Mineral resources of Colorado, 1st sequel: Denver, Colorado Mineral Resources Board, p. 505, 625-651.

10. Afifi, A.M., 1981, Stratigraphy, petrology, and structure of Precambrian metavolcanic rocks in the Iris district, Gunnison and Saguache Counties, Colorado, in Epis, R.C., and Callender, J.F., eds., Western Slope, Colorado--Western Colorado and eastern Utah: [Socorro?], New Mexico Geological Society Guidebook 32, p. 287-292.

11. Afifi, A.M., 1981, Precambrian geology of the Iris area, Gunnison and Saguache Counties, Colorado: Golden, Colorado School of Mines, Master's thesis, $197 \mathrm{p}$.

12. Allen, M.J., and Morrison, S.M., 1973, Bacterial movement through fractured bedrock: Ground Water, v. 11, no. 2, p. 6-10.

13. Alley, W.M., 1982, The relative importance of ground-water and surfacewater supplies to oil-shale development, Piceance basin, Colorado: U.S. Geological Survey Open-File Report 82-340, 50 p.

14. Alley, W.M., 1983, Ground water for oil-shale development, Piceance basin, Colorado: Ground Water, v. 21, no. 4, p. 456-464.

15. Alley, W.M., Britton, L.J., and Boyd, E.L., 1978, Reconnaissance evaluation of water resources for hydraulic coal mining, Grand Hogback coal field, Garfield and Rio Blanco Counties, Colorado: U.S. Geological Survey Open-File Report 78-885, 66 p. 
16. American Geological Institute, comp., 1976, Bibliography and index of Colorado geology, 1875 to 1975: Colorado Geological Survey Bulletin 37, $488 \mathrm{p}$.

17. American Geological Institute, 1983, Bibliography and index of Colorado geology, 1975-1980: Colorado Geological Survey Bulletin 45, 294 p.

18. American Geological Institute, 1983, Bibliography and index of Colorado geology, 1981-1982: Colorado Geological Survey Information Series 19, $111 \mathrm{p}$.

19. American Geological Institute, 1987, Bibliography and index of Colorado geology, 1983: Colorado Geological Survey Information Series 21, 127 p.

21. American Institute of Professional Geologists, Colorado Section, 1979, Position paper--Ground water in Colorado: Colorado Communicator, v. 9, no. 6, p. $20-22$.

22. Anderson, R.I., and Hutchinson, E.C., 1955, Air-photo stratigraphy of the Four Corners area, in Cooper, J.C., ed., Geology of parts of Paradox, Black Mesa, and San Juan basins, [1st] Four Corners field conference, 1955 [Guidebook]: [Durango, Colo.], Four Corners Geological Society, p. $30-45$.

23. Archibald, J.D., 1987, Late Cretaceous (Judithian and Edmontonian) vertebrates and geology of the Williams Fork Formation, in Currie, P.J., and Koster, E.H., eds., Fourth Symposium on Mesozoic Terrestrial Ecosystems: Drumheller, Alberta, Canada, Tyrrell Museum of Palaeontology Occasional Paper 3, p. 7-11.

24. Armstrong, A.K., and Holcomb, L.D., 1989, Stratigraphy, facies, and paleotectonic history of Mississippian rocks in the San Juan basin of northwestern New Mexico and adjacent areas, chap. D, in Evolution of sedimentary basins--San Juan basin: U.S. Geological Survey Bulletin 1808-D, p. D1-D21.

25. Armstrong, A.K., and Mamet, B.L., 1976, Biostratigraphy and regional relations of the Mississippian Leadville Limestone in the San Juan Mountains, southwestern Colorado: U.S. Geological Survey Professional Paper 985,25 p.

26. Armstrong, A.K., and Mamet, B.L., 1977, Biostratigraphy and paleogeography of the Mississippian System in northern New Mexico and adjacent San Juan Mountains of southwestern Colorado, in Fassett, J.E., ed., Guidebook of San Juan basin III, northwestern New Mexico: [Socorro?], New Mexico Geological Society, 28th field conference, 1977, p. 111-127.

27. Atwood, W.W., 1928, Eocene glaciation in Colorado: Pan-Pacific Science Congress, 3d, Tokyo, 1926, Proceedings, p. 1826-1833.

28. Atwood, W.W., and Atwood, W.R., 1926, Gunnison tillite of Eocene age [Colorado]: Journal of Geology, v. 34, no. 7, p. 612-622.

29. Aubrey, W.M., 1988, Measured sections and environmental reconstructions of uppermost Jurassic to lowermost Upper Cretaceous rocks on the northern side of the San Juan Basin, southwestern Colorado: U.S. Geological Survey Open-File Report 88-231, 80 p., 2 oversize sheets.

30. Aubrey, W.M., 1989, Mid-Cretaceous alluvial-plain incision related to eustasy, southeastern Colorado Plateau: Geological Society of America Bulletin, v. 101, no. 4, p. 443-449.

31. Austin, A.C., 1971, Structure contours and overburden on the top of the Mahogany Zone, Green River Formation, in the northern part of the Piceance Creek basin, Rio Blanco County, Colorado: U.S. Geological Survey Miscellaneous Field Studies Map MF-309, scale 1:62,500. 
32. Austin, E.B., 1957, Corral Peak Anticline, Grand County, Colorado, in Finch, W.C., ed., Guidebook to the geology of North and Middle Parks basin, Colorado: Denver, Rocky Mountain Association of Geologists, p. 97-98, 1 oversize page.

33. Austin Map Company, 1954, Subsurface structure map of the Uinta Basin in Utah and Colorado: Fort Worth, Tex., Austin Map Company, scale 1:506,880.

34. Baars, D.L., 1979, The Permian system, in Baars, D.L., ed., Permianland--A field symposium-guidebook of the Four Corners Geological Society: [Durango, Colo.], Four Corners Geological Society, 9th field conference, p. 1-6.

35. Baars, D.L., 1988, Triassic and older stratigraphy--Southern Rocky Mountains and Colorado Plateau, in Sloss, L.L., ed., The geology of North America: Denver, Geological Society of America, v. D-2, p. 53-64.

36. Baars, D.L., and Ellingson, J.A., 1984, Geology of the western San Juan Mountains, in Brew, D.C., ed., Paleotectonics; San Juan Mountains wist Durango area; Geological Society of America, Rocky Mountain Section, 37th annual meeting, Durango, Colo., 1984: Durango, Colo., Four Corners Geological Society, Geological Society of America Field Trip Guidebook 1, 3-5, p. 1-45.

37. Baars, D.L., Ellingson, J.A., and Spoelhof, R.W., 1987, Grenadier fault block, Coalbank to Molas Passes, southwestern Colorado: in Beus, S.S., ed., Rocky Mountain Section of the Geological Society of America, centennial field guide, v. 2, p. 343-348.

38. Baars, D.L., and Knight, R.L., 1957, Pre-Pennsylvanian stratigraphy of the San Juan Mountains and Four Corners area, in Kottlowski, F.E., and Baldwin, Brewster, eds., Guidebook of southwestern San Juan Mountains, Colorado, 8th field conference, 1957: Socorro, New Mexico Geological Society, p. 108-131.

39. Baars, D.L., and See, P.D., 1968, Pre-Pennsylvanian stratigraphy and paleotectonics of the San Juan Mountains, southwestern Colorado: Geological Society of America Bulletin, v. 79, no. 3, p. 333-349.

40. Baars, D.L., and Stevenson, G.M., 1979, Permian rocks of the San Juan Basin, in Baars, D.L., ed., Permianland--A field symposium-guidebook of the Four Corners Geological Society: [Durango, Colo.], Four Corners Geological Society, 9th field conference, p. 59-63.

41. Baars, D.L., and Stevenson, G.M., 1981, Tectonic evolution of western Colorado and eastern Utah, in Epis, R.C., and Callender, J.F., eds., Western Slope, Colorado--Western Colorado and eastern Utah: [Socorro?], New Mexico Geological Society Guidebook 32, p. 105-112.

42. Baars, D.L., and Stevenson, G.M., 1981, Tectonic evolution of the Paradox basin, Utah and Colorado, in Wiegand, D.L., ed., Geology of the Paradox basin: [Denver], Rocky Mountain Association of Geologists field conference, [Guidebook], v. 1981, p. 23-31.

43. Baars, D.L., and Stevenson, G.M., 1986, Vertically stacked unconformities as paleotectonic indicators, Paradox basin, Utah and Colorado [abs.]: Geological Society of America Abstracts with Programs, v. 18, no. 6, p. 531.

44. Baars, D.L., ed., 1979, Permianland--A field symposium-guidebook of the Four Corners Geological Society: [Durango, Colo.], Four Corners Geological Society, 9th field conference, $186 \mathrm{p}$.

45. Bader, J.W., 1983, Section A-A', subsurface correlations of some Upper Cretaceous and Tertiary rocks from the Cherokee Ridge, Wyoming, to the southeast flank of the Sand Wash basin, Colorado: U.S. Geological Survey Open-File Report 83-362, 2 sheets, no scale listed. 
46. Bader, J.W., Gill, J.R., Cobban, W.A., and Law, E.B., 1983, Biostratigraphic correlation chart of some Upper Cretaceous rocks from the Lost Soldier area, Wyoming, to west of Craig, Colorado: U.S. Geological Survey Miscellaneous Field Studies Map MF-1548, no scale listed.

47. Bailey, M.H., 1979, Bedrock geology of western Taylor Park, Gunnison County, Colorado: Corvallis, Oregon State University, Master's thesis, unknown pagination.

48. Baker, F.G, 1985, Development of a pore interaction model for hydrodynamic dispersion during flow through porous media [abs.?]: EOS, American Geophysical Union Transactions, v. 66, no. 46, p. 905.

49. Baker, F.G., 1985, Development of a pore interaction model for hydrodynamic dispersion during flow through porous media: Boulder, University of Colorado, Ph.D. dissertation, $161 \mathrm{p}$.

50. Baker, F.G., and Curtis, B.F., 1985, Development of a pore interaction model for hydrodynamic dispersion, in Morel-Seytoux, H.J., and Doehring, D.0., eds., Joint proceedings of the fifth annual American Geophysical Union Front Range Branch hydrology days, and the fourteenth annual Rocky Mountain ground water conference, Fort Collins, Colo., Apr. 16-20, 1985: Fort Collins, Colo., Hydrology Days Publishing, p. 53-60.

51. Baldwin, B., 1970, Problem-approach guidelines applied to Dolores Peak Quadrangle: Journal of Geologic Education, v. 18, no. 4, p. 155-160.

52. Ball, M.W., 1925, Waters from the Green River Shale [abs.?]: American Association of Petroleum Geologists Bulletin, v. 9, no. 1, p. 171.

53. Baltz, E.H., 1957, Distribution and thickness of salt in the Paradox Basin of southwestern Colorado and southeastern Utah--A preliminary report: U.S. Geological Survey Trace Element Investigations Report TEM-706, 42 leaves.

54. Banghart, R.C., 1957, Geology and ore deposits of the northeast portion of Breckenridge district (Summit County), Colorado: Golden, Colorado School of Mines, Master's thesis, $78 \mathrm{p}$.

55. Banks, C.E., Bradley, W.S., Franciscotti, B.C., and others, 1978, Simulated dewatering requirements at an oil shale surface mine, Piceance Creek basin, Colorado: Colorado School of Mines Mineral Industries Bulletin, v. 21, no. 2, 11 p.

56. Barclay, C.S.V., 1968, Geology of the Gore Canyon-Kremmling area, Grand County, Colorado: U.S. Geological Survey Open-File Report 1042, 187 p.

57. Barker, Fred, 1969, Precambrian geology of the Needle Mountains, southwestern Colorado: U.S. Geological Survey Professional Paper 644-A, 35 p.

58. Barker, Fred, and Wyant, D.G., 1976, Geologic map of the Jefferson Quadrangle, Park and Summit Counties, Colorado: U.S. Geological Survey Geologic Quadrangle Map GQ-1345, scale 1:24,000.

59. Barnes, Harley, 1953, Geology of the Ignacio and Pagosa Springs Quadrangles, La Plata and Archuleta Counties, Colorado: U.S. Geological Survey 0il and Gas Investigations Map OM-138, scale 1:63,360.

60. Barnes, Harley, Baltz, E.H., Jr., and Hayes, P.T., 1954, Geology and fuel resources of the Red Mesa area, La Plata and Montezuma Counties, Colorado: U.S. Geological Survey $0 i 1$ and Gas Investigations Map OM-149, scale $1: 62,500$.

61. Barnum, B.E., and Garrigues, R.S., 1980, Geologic map and coal sections of the Cactus Reservoir Quadrangle, Rio Blanco and Moffat Counties, Colorado: U.S. Geological Survey Miscellaneous Field Studies Map MF-1179, 2 sheets, scale 1:24,000. 
62. Barnwel1, W.W., 1955, The geology of the south Hahns Peak district, Routt County, Colorado, in Ritzma, H.R., and Oriel, S.S., eds., Guidebook to the geology of northwest Colorado, Intermountain Association of Petroleum Geologists, 6th annual field conference, and Rocky Mountain Association of Geologists annual field conference, 1955: Salt Lake City, Intermountain Association of Petroleum Geologists p. 73-74.

64. Barrett, J.K., and Pear1, R.H., 1976, Hydrogeologic data of thermal springs and wells in Colorado: Colorado Geological Survey Information Series 6, $124 \mathrm{p}$.

65. Barrett, J.K., and Pearl, R.H., 1978, An appraisal of Colorado's geothermal resources: Colorado Geological Survey Bulletin 39, 224 p.

66. Barrett, J.K., Pear1, R.H., and Pennington, A.J., 1976, Map showing thermal springs, wells and heat-flow contours in Colorado: Colorado Geological Survey Information Series 4, scale 1:1,000,000.

67. Barteaux, W.L., and Biezugbe, G., 1987, Evaluation of baseline conditions at Lease Tract C-a, Rio Blanco County, Colorado: Laramie, University of Wyoming Research Corporation Report DOE/MC/11076--2442, 46 p.

68. Bartleson, B.L., 1968, Stratigraphy and petrology of the Gothic Formation (Pennsylvanian, Desmoinesian), Elk Mountains, (western) Colorado:

Boulder, University of Colorado, Ph.D. dissertation, 216 p.

69. Bartleson, B.L., 1972, Permo-Pennsylvanian stratigraphy and history of the Crested Butte-Aspen region, in Paleozoic stratigraphy and structural evolution of Colorado: Colorado School of Mines Quarterly, v. 67, no. 4, p. 187-248.

70. Bartleson, B.L., Bryant, Bruce, and Mutschler, F.E., 1968, Permian and Pennsylvanian stratigraphy and nomenclature, Elk Mountains, Colorado, in Geological Survey research, 1968, chap. C: U.S. Geological Survey Professional Paper 600-C, p. C53-C60.

71. Bass, N.W., 1946, Subsurface maps of the Rangely Anticline, Rio Blanco County, Colorado: U.S. Geological Survey 0il and Gas Investigations Map OM-67, scale $1: 31,680$.

72. Bass, N.W., Eby, J.B., and Campbel1, M.R., 1955, Geology and mineral fuels of parts of Routt and Moffat Counties, Colorado: U.S. Geological Survey Bulletin 1027-D, p. 143-250.

73. Bass, N.W., and Northrop, S.A., 1950, South Canyon Creek Dolomite Member, a unit of Phosphoria age in Maroon Formation near Glenwood Springs, Colorado: American Association of Petroleum Geologists Bulletin, v. 34, no. 7, p. 1540-1551.

74. Bass, N.W., and Northrop, S.A., 1963, Geology of Glenwood Springs Quadrangle and vicinity, northwestern Colorado: U.S. Geological Survey Bulletin 1142-J, p. J1-J74.

75. Bassett, C.F., 1939, Paleozoic section in the vicinity of Dotsero, Colorado: Geological Society of America Bulletin, v. 50, no. 12, pt. 1, p. 1851-1865.

76. Batory, B.L., 1981, Analysis of the lacustrine sediments of the Creede Formation, Mineral County, Colorado: Socorro, New Mexico Institute of Mining and Technology, Master's thesis, 120 p., 3 plates.

77. Bauer, C.M., 1932, The Rocky Mountain region before the Rockies--The romance of the Rockies: Denver, Colorado State Planning Committee, unpublished report.

78. Bazrafshan, Khosrow, 1981, Geology and economic geology of the upper Cunningham Gulch, southeast Silverton, Colorado: Wichita, Kans., Wichita State University, Master's thesis, unknown pagination. 
79. Beattie, D.A., 1958, Geology of part of southeastern Moffat County, Colorado: Golden, Colorado School of Mines, Master's thesis, $176 \mathrm{p}$.

80. Beaty, D.W., 1988, Stratigraphy of the Leadville Dolomite, in Holden, G.S., ed., Geological Society of America Centennial Meeting, Denver, Field Trip Guidebook 1988: Professional Contributions of Colorado School of Mines 12, p. 109-111.

81. Beaty, D.W., Johansing, R.J., and Thompson, T.B., 1988, Stratigraphy of the Mississippian Leadville Dolomite, Gilman to Leadville, Colorado-Redefinition of the Castle Butte and Red Cliff Members, in Thompson, T.B., and Beaty, D.W., eds., Geology and mineralization of the GilmanLeadville area, Colorado--Guidebook prepared for Society of Economic Geologists field conference, Oct., 24-30, 1988: Fort Collins, Colo., Society of Economic Geologists Guidebook Series, v. 2, p. 9-34.

82. Beaumont, E.C., and Read, C.B., 1950, Geologic history of the San Juan basin area, New Mexico and Colorado in Guidebook of the San Juan basin, New Mexico and Colorado--New Mexico Geological Society, 1st field conference, 1950: Socorro, New Mexico Geological Society, p. 49-52.

83. Bechler, G.R., 1877, Geological report on the Middle and South Parks, Colorado, and adjacent territory: U.S. Geological and Geographical Survey of the Territories (Hayden) annual report 9, p. 371-440.

84. Beckett, R.L., 1955, Geology of the Red Canyon area, Eagle County, Colorado: Boulder, University of Colorado, Master's thesis, $36 \mathrm{p}$.

85. Bell, K.G., and Rogers, A.S., 1950, Experimental gamma-ray logging of drill holes in the Calamity area, Mesa County, Colorado: U.S. Geological Survey [Trace Element Investigations?] Report TEM-84.

86. Belt, C.B., Jr., 1953, A study of the regional geology and ore deposits of the Red Cliff district, Colorado: Williamstown, Mass., Williams College, Honor's thesis, $87 \mathrm{p}$.

87. Benson, J.C., and Bass, N.W., 1955, Eagle River Anticline, Eagle County, Colorado: American Association of Petroleum Geologists Bulletin, v. 39, no. 1 , p. 103-106.

88. Berg, R.R., and Rold, J.W., eds., 1961, Symposium on lower and middle Paleozoic rocks of Colorado, Rocky Mountain Association of Geologists, 12th field conference, 1961: Denver, Rocky Mountain Association of Geologists, $236 \mathrm{p}$.

89. Bergendahl, M.H., 1963, Geology of the northern part of the Tenmile Range, Summit County, Colorado: U.S. Geological Survey Bulletin 1162-D, p. D1-D19.

90. Bergendahl, M.H., 1969, Geologic map and sections of the southwest quarter of the Dillon Quadrangle, Eagle and Summit Counties, Colorado: U.S. Geological Survey Miscellaneous Geologic Investigations Map I-563, scale $1: 24,000$.

91. Bergeon, T.C., 1986, Seismic character study, Ismay Cycle, Paradox Formation, Paradox basin, southwest Colorado: Golden, Colorado School of Mines, Master's thesis, $179 \mathrm{p}$.

92. Bergin, M.J., 1955, Washakie basin, Wyoming and Colorado--Maybel1-Lay area, Moffat County, Colorado: U.S. Geological Survey Trace Element Investigations Report TEI-590, p. 176-179.

93. Bergin, M.J., 1956, Maybell-Lay area, Moffat County, Colorado: U.S . Geological Survey Trace Element Investigations Report TEI-640, p. 138-143.

94. Bergin, M.J., 1957, Maybell-Lay area, Colorado: U.S. Geological Survey Trace Element Investigations Report TEI-690, book 2, p. 280-291. 
95. Berman, A.E., Poleschook, D., Jr., and Dimelow, T.E., 1980, Jurassic and Cretaceous systems of Colorado, in Kent, H.C., and Porter, K.W., eds., Colorado geology: Denver, Rocky Mountain Association of Geologists, p. 111-128.

96. Berthoud, E.L., 1881, Artesian wells in Colorado: Kansas City Review of Science and Industry, v. 4, p. 536-546.

97. Bianchi, Luiz, and Snow, D.T., 1969, Permeability of crystalline rock interpreted from measured orientations and apertures of fractures: Annals of Arid Zone, v. 8, no. 2, p. 231-245.

98. Biggar, N.E., Harden, D.R., and Gillam, M.L., 1981, Quaternary deposits of the Paradox basin, in Wiegand, D.L., ed., Geology of the Paradox basin: Denver, Rocky Mountain Association of Geologists field conference [Guidebook], v. 1981, p. 129-145.

99. Birman, J.H., 1982, Some questions on Piceance basin hydrology, in Gary, J.H., ed., Fifteenth Oil Shale Symposium Proceedings: Golden, Colorado School of Mines Press, p. 149-154.

100. Bittinger, M.W., 1959, Colorado's ground-water problems--Ground water in Colorado: Fort Collins, Colorado State University Agricultural Experiment Station Bulletin 504-S, 28 p.

101. Bittinger, M.W., 1962, Ground-water recharge research in Colorado, 1961, in Biennial Conference on ground-water recharge, 3d, Berkeley, Calif., 1961, Proceedings: Fresno, Calif., Soil Water Conservation Research Division, Southwest Branch, Ground-Water Recharge Laboratory.

102. Blackwelder, R.E., 1955, Geological exhibit, in This is Dinosaur [National Monument]-Echo Park country and its magic rivers [Colorado and Utah]: New York, Alfred A. Knopf, p. 18-30.

103. Blair, R.W., and Heiny, L.W., 1952, Piceance Creek basin of Colorado--A portion of the Uintah [Uinta] Basin: Petroleum Engineer, v. 24, no. 3, p. $A 48,53,56,58,60$.

104. Blanchard, P.E., Blanchard, C.I., and Kirchner, J.W., 1988, Surface waters, snow melt, and ground water in an alpine/subalpine watershed [abs.?]: EOS, American Geophysical Union Transactions, v. 69, no. 44, p. 1199.

105. Bliss, J.D., 1983, Colorado--Basic data for thermal springs and wells as recorded in Geotherm: U.S. Geological Survey Open-File Report 83-429, $176 \mathrm{p}$.

106. Blodgett, R.H., 1985, Calcareous paleosols in the Triassic Dolores Formation, southwestern Colorado [abs.]: Geological Society of America Abstracts with Programs, v. 17, no. 7, p. 525.

107. Blodgett, R.H., 1988, Calcareous paleosols in the Triassic Dolores Formation, southwestern Colorado, in Reinhardt, Juergen, and Sigleo, W.R., eds., Paleosols and weathering through geologic time--Principles and applications: Boulder, Colo., Geological Society of America Special Paper 216, p. 103-121.

108. Boardman, Leona, and Brown, Annabe1, comps., 1948, Geologic map index of Colorado: U.S. Geological Survey Index to Geologic Mapping in United States 3, scale 1:750,000.

110. Boardman, Leona, comp., 1954, Geologic map index of Colorado: U.S. Geological Survey Index to Geologic Mapping in the United States [3?], scale 1:750,000.

111. Boardman, R.L., 1957, Uravan district, Colorado: U.S. Geological Survey Trace Element Investigations Report TEI-700, p. 18-25, 29-30. 
112. Boardman, R.L., Ekren, E.B., and Bowers, H.E., 1956, Sedimentary features of upper sandstone lenses of the Salt Wash Sandstone Member and their relation to uranium-vanadium deposits in the Uravan district, Montrose County, Colorado, in Page, L.R., Stocking, H.E., and Smith, H.B., comps.,

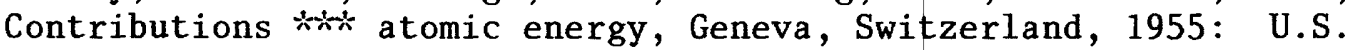
Geological Survey Professional Paper 300, p. 221-226.

113. Bodine, M.W., Jr., Hay, R.L., Madsen, B.M., and Altaner, S.P., 1987, Lacustrine volcaniclastic sediments in the Creede Formation, San Juan Mountains, Colorado [abs.]: Geological Society of America Abstracts with Programs, v. 19, no. 5, p. 261-262.

114. Boegli, W.J., and Murphy, A.P., 1985, Pilot plant studies of two processes for oxidation of aqueous sulfide--Paradox Valley unit, Colorado River basin salinity control project: U.S. Bureau of Reclamation Report REC-ERC-84-18, 97 p.

115. Boettcher, A.J., 1971, Evaluation of the water supply at six sites in the Curecanti Recreation Area, southwestern Colorado: U.S. Geological Survey Open-File Report 71-0005, $28 \mathrm{p}$.

116. Boettcher, A.J., 1972, Ground-water occurrence in northern and central parts of western Colorado: Colorado Water Resources Circular 15, 25 p.

117. Bogart, L.E., 1957, Photogeology finds a place in the Four Corners: Petroleum Enginner, v. 29, no. 13, p. B53, B56, B60, B62.

118. Boggs, Sam, Jr., 1964, Stratigraphy and petrology of the Upper Minturn Formation (Pennsylvanian), east-central Eagle County, Colorado: Boulder, University of Colorado, Ph.D. dissertation, $210 \mathrm{p}$.

119. Boggs, Sam, Jr., 1966, Petrology of Minturn Formation, east-central Eagle County, Colorado: American Association of Petroleum Geologists Bulletin, v. 50 , no. 7, p. 1399-1422.

120. Bombolakis, E.G., 1959, Geology of the Hot Sulphur Springs-Parshall area of Middle Park, Grand County, Colorado: Golden, Colorado School of Mines, Master's thesis, $146 \mathrm{p}$.

121. Bookstrom, A.A., 1964, Geology of the Yellowjacket Anticline, Rio Blanco County, northwestern Colorado: Boulder, University of Colorado, Master's thesis, $76 \mathrm{p}$.

122. Botinelly, Theodore, and Fischer, R.P., 1959, Mineralogy and geology of the Rifle and Garfield mines, Garfield County, Colorado, in Garrels, R.M., and Larsen, E.S., comps., Geochemistry and mineralogy of the Colorado Plateau uranium ores: U.S. Geological Survey Professional Paper 320, pt. 19, p. 213-218.

123. Boudette, E.L., 1956, Progress report on investigation of methods using aerial photographs in regional fracture pattern studies on the Colorado Plateau: U.S. Geological Survey [Trace Element Investigation?] Report TEM-728.

124. Bowker, K.A., and Jackson, W.D., 1989, The Weber Sandstone at Rangely Field, Colorado, in Coalson, E.B., Kaplan, S.S., Keighin, C.W., Oglesby, C.A., and Robinson, J.W., eds., Petrogenesis and petrophysics of selected sandstone reservoirs of the Rocky Mountain region: Denver, Rocky Mountain Association of Geologists, p. 65-80.

125. Bowman-Bilbey, S.A., Bowman, J.T., and Drake, R.E., 1986, Interpretation of the Morrison Formation as a time-transgressive unit [abs.], in North American Paleontological Convention, 4th, Boulder, Colo., Aug. 12-15, 1986: North American Paleontologists Proceedings 4, p. A5.

126. Boyd, Vicky, 1981, The groundwater watchers: Groundwater Digest, 1981, v. 4 , no. 9, p. 34-37. 
127. Boyer, W.H., 1956, Geologic reconnaissance of the northwestern White River plateau, Rio Blanco and Garfield Counties, Colorado: U.S. Geological Survey Report RME-90, 46 p. [Available from U.S. Atomic Energy Commission, Washington, D.C.]

128. Boyle, J.M., Covay, K.J., and Bauer, D.P., 1984, Quantity and quality of streamflow in the White River basin, Colorado and Utah: U.S. Geological Survey Water-Resources Investigations Report 84-4022, $84 \mathrm{p}$.

129. Boyles, J.M., Kauffman, E.G., Kiteley, L.W., and Scott, A.J., 1981, Depositional systems, Upper Cretaceous Mancos Shale and Mesaverde Group, northwestern Colorado: [Denver?], Society of Economic Paleontologists and Mineralogists, Rocky Mountain Section, 1981 fall field trip guidebook, various pagination.

130. Boyles, J.M., and Scott, A.J., 1981, Part I, in Boyles, J.M., Kauffman, E.G., Kiteley, L.W., and Scott, A.J., Depositional systems, Upper Cretaceous Mancos Shale and Mesaverde Group, northwestern Colorado: [Denver?], Society of Economic Paleontologists and Mineralogists, Rocky Mountain Section, 1981 fall field trip guidebook, p. 1.1-1.82.

131. Bozanic, Dan, 1955, A brief discussion on the subsurface Cretaceous rocks of the San Juan basin, in Cooper, J.C., ed., Geology of parts of Paradox, Black Mesa, and San Juan basins, [1st], Four Corners field conference, 1955 [Guidebook]: [Durango, Colo.], Four Corners Geological Society, p. 89-107.

132. Braddock, W.A., 1969, Geology of the Empire Quadrangle, Grand, Gilpin, and Clear Creek Counties, Colorado: U.S. Geological Survey Professional Paper 616, 56 p.

133. Braddock, W.A., and Cole, J.C., 1978, Preliminary geologic map of the Greeley $1^{\circ}$ by $2^{\circ}$ Quadrangle, Colorado and Wyoming: U.S. Geological Survey Open-File Report 78-532, 11 p.

134. Bradish, B.B., and Mills, N.K., 1950, Pennsylvanian rocks of the San Juan basin, in Guidebook of the San Juan basin, New Mexico and Colorado--New Mexico Geological Society, 1st field conference, 1950: Socorro, New Mexico Geological Society, p. 58-61.

135. Bradley, W.A., 1952, Jurassic and pre-Mancos Cretaceous stratigraphy of the eastern Uinta Mountains, Colorado (Moffat and Rio Blanco Counties); Utah: Boulder, University of Colorado, Master's thesis, $74 \mathrm{p}$.

136. Bradley, W.A., 1955, Jurassic and pre-Mancos Cretaceous stratigraphy of the eastern Uinta Mountains, Utah-Colorado, in Ritzma, H.R., and Oriel, S.S., eds., Guidebook to the geology of northwest Colorado, Intermountain Association of Petroleum Geologists, 6th annual field conference, and Rocky Mountain Association of Geologists annual field conference, 1955 : Salt Lake City, Intermountain Association of Petroleum Geologists p. 21-26.

137. Bradley, W.C., 1965, Glacial geology, periglacial features, and erosion surfaces in Rocky Mountain National Park, trip 6, in Guidebook for oneday field conferences, Boulder area, Colorado, International Association of Quaternary Research, 7th Congress, 1965, Lincoln, Nebr.: [Lincoln?], Nebraska Academy of Sciences, p. 27-33.

138. Bradley, W.H., 1945, Geology of the Washakie basin, Sweetwater and Carbon Counties, Wyoming, and Moffat County, Colorado: U.S. Geological Survey Oil and Gas Investigations Map 0M-32, scale 1:190,080. [Reprinted 1954.]

139. Bradley, W.H., 1961, Geologic map of a part of southwestern Wyoming and adjacent States: U.S. Geological Survey Miscellaneous Geologic Investigations Map I-332, scale 1:250,000. 
140. Bredehoeft, J.D., Wolff, R.G., Keys, W.S., and others, 1976, Hydraulic fracturing to determine the regional in situ stress field, Piceance basin, Colorado: Geological Society of America Bulletin, v. 87, no. 2, p. 250-258.

141. Breed, C.E., 1956, The Dakota Group (Lower Cretaceous) in northwestern Colorado, Moffat and Rio Blanco Counties and vicinity: Boulder, University of Colorado, Master's thesis, $79 \mathrm{p}$.

142. Brennan, W.J., 1969, Structural and surficial geology of the west flank of the Gore Range, Colorado: Boulder, University of Colorado, Ph.D. dissertation, $109 \mathrm{p}$.

143. Bridwel1, R.J., 1968, Geology of the Kerber Creek area, Saguache County, Colorado: Golden, Colorado School of Mines, Master's thesis, 104 p.

144. Brinton, L., and Wray, J.L., 1986, Pennsylvanian (Minturn Formation) algal-mound facies, Rio Blanco County, Colorado, in Stone, D.S., and Johnson, K.S., eds., New interpretations of northwest Colorado geology: Denver, Rocky Mountain Association of Geologists Guidebook, p. 103-112.

145. Brinton, Lise, 1986, Deposition and diagenesis of Middle Pennsylvanian (Desmoinesian) phylloid algal banks, Paradox Formation, Ismay Zone, Ismay Field and San Juan Canyon, Paradox basin, Utah and Colorado: Golden, Colorado School of Mines, Master's thesis, $314 \mathrm{p}$.

146. Brock, M.R., and Barker, Fred, 1972, Geologic map of the Mount Harvard Quadrangle, Chaffee and Gunnison Counties, Colorado: U.S. Geological Survey Geologic Quadrangle Map GQ-952, scale 1:62,500.

147. Brogden, R.E., and Giles, T.F., 1976, Availability and chemical characteristics of ground water in central La Plata County, Colorado: U.S. Geological Survey Water-Resources Investigations Report 76-69, scale $1: 125,000$. [Text included.]

148. Brogden, R.E., and Giles, T.F., 1976, Availability and chemical quality of ground water in the Crystal River and Cattle Creek drainage basins near Glenwood Springs, west-central Colorado: U.S. Geological Survey Water-Resources Investigations Report 76-70, 2 sheets, scale 1:125,000. [Text included.]

149. Brogden, R.E., and Giles, T.F., 1977, Reconnaissance of ground-water resources in a part of the Yampa River basin between Craig and Steamboat Springs, Moffat and Routt Counties, Colorado: U.S. Geological Survey Water-Resources Investigations Report 77-4, scale 1:360,000. [Text included.]

150. Brogden, R.E., Hutchinson, E.C., and Hillier, D.E., 1977, Availability and quality of ground water, Southern Ute Indian Reservation, southwestern Colorado: U.S. Geological Survey Open-File Report 77-623, 71 p.

151. Brogden, R.E., Hutchinson, E.C., and Hillier, D.E., 1979, Availability and quality of ground water, Southern Ute Indian Reservation, southwestern Colorado: U.S. Geological Survey Water-Supply Paper 1576-J, $28 \mathrm{p}$.

152. Bromfield, C.S., 1967, Geology of the Mount Wilson Quadrangle, western San Juan Mountains, Colorado: U.S. Geological Survey Bulletin 1227, $100 \mathrm{p}$.

153. Bromfield, C.S., and Conroy, A.R., 1963, Preliminary geologic map of the Mount Wilson Quadrangle, San Miguel County [and Dolores County], Colorado: U.S. Geological Survey Mineral Investigations Field Studies Map MF-273, scale 1:24,000.

154. Bronson, R.J., 1979, Reconnaissance drill holle in the Yampa Coal Field, Routt County, Colorado, 1979: U.S. Geological Survey Open-File Report 79-1593, 5 p. 
155. Brookman, J.A., 1968, Colorado ground-water levels, spring, 1968: Fort Collins, Colorado State University Experiment Station CER67-69JB2, 2 sheets, scale: 1 inch equals about 5 miles.

156. Brooks, Tom, 1983, Hydrology and subsidence potential of proposed coallease tracts in Delta County, Colorado: U.S. Geological Survey WaterResources Investigations Report 83-4069, 32 p.

157. Brooks, Tom, 1985, Hydrology of coal-lease areas near Durango, Colorado: U.S. Geological Survey Water-Resources Investigations Report 85-4125, $46 \mathrm{p}$.

158. Brooks, Tom, 1986, Geohydrology and potential hydrologic effects of underground coal mining in the Rapid Creek basin, Mesa County, Colorado: U.S. Geological Survey Water-Resources Investigations Report 86-4172, $28 \mathrm{p}$.

159. Brooks, Tom, and Ackerman, D.J., 1985, Reconnaissance of ground-water resources in the lower Gunnison River basin, southwestern Colorado: U.S. Geological Survey Water-Resources Investigations Report 84-4185, $30 \mathrm{p}$.

160. Brown, A.L., 1950, Geology of the Round Mountain intrusive, Gunnison County, Colorado: Lexington, University of Kentucky, Master's thesis, $27 \mathrm{p}$.

161. Brown, Adrian, and Heley, W., 1977, U.S.B.M. Pilot Hole "X", Horse Draw, Rio Blanco County, Colorado--Volume 1, Section 2, Permeability testing: Washington, D.C., U.S. Bureau of Mines Open-File Report 103(2)-77, 26 p.

162. Brown, Adrian, and Stewart, B.M., 1978, Water management for oil shale mining and retorting in the Piceance Creek basin, Colorado, in Gary, J.H., ed., Eleventh Oil Shale Symposium Proceedings: Golden, Colorado School of Mines Press, p. 214-226.

163. Brown, Phillip, Smith, Robert, and Wendt, Gary, 1980, Interrelationship of groundwater with overburden and reclaimed spoil at an active surface mine in southwestern Colorado, in Graves, D.H., and De Vore, William, eds., Proceedings, 1980 Symposium on surface mining hydrology, sedimentology, and reclamation: Lexington, University of Kentucky, p. 225-234.

164. Brownfield, M.E., 1976, Geophysical logs of seventeen holes drilled in 1976 in the Yampa Coal Field, northwestern Colorado: U.S. Geological Survey Open-File Report 76-817, 4 leaves.

165. Brownfield, M.E., 1978, Reconnaissance drilling during 1976 in the Rattlesnake Butte Quadrangle, Routt County, Colorado: U.S. Geological Survey Open-File Report 78-364, 11 p.

166. Brownfield, M.E., 1978, Reconnaissance drilling during 1977 in the Yampa Coal Field, Moffat and Routt Counties, Colorado: U.S. Geological Survey Open-File Report 78-365, 135 p.

167. Brownfield, M.E., 1978, Reconnaissance drilling during 1978 in the Craig Quadrangle, Moffat County, Colorado: U.S. Geological Survey Open-File Report 78-1039, $16 \mathrm{p}$.

168. Brownfield, M.E., and Anderson, Kevin, 1979, Geologic map and coal sections of the Lay SE Quadrangle, Moffat County, Colorado: U.S. Geological Survey Open-File Report 79-1680, 2 sheets, scale 1:24,000.

169. Brownfield, M.E., and Anderson, Kevin, 1988, Geologic map and coal sections of the Lay SE Quadrangle, Moffat County, Colorado: U.S. Geological Survey Coal Investigations Map C-0117, 2 sheets scale 1:24,000.

170. Brownfield, M.E., and Johnson, E.A., comps., 1985, Geologic map index of the Meeker $1^{\circ}$ by $1 / 2^{\circ}$ Quadrangle, Garfield, Moffat, Rio Blanco, and Routt Counties, Colorado: U.S. Geological Survey Open-File Report 85-0523, scale $1: 100,000$. 
171. Brownfield, M.E., and Johnson, E.A., 1986, A regionally extensive altered air-fall ash for use in correlation of lithofacies in the Upper Cretaceous Williams Fork Formation, northeastern Piceance Creek and southern Sand Wash basins, Colorado, in Stone, D.S., and Johnson, K.S., eds., New interpretations of northwest Colorado geology: Denver, Rocky Mountain Association of Geologists Guidebook, p. 165-170.

172. Brownfield, M.E., and Prost, G.L., 1979, Geologic map and coal sections of the Lay Quadrangle, Moffat County, Colorado: U.S. Geological Survey Open-File Report 79-1679, 2 sheets, scale 1:24,000.

173. Bruns, D.L., 1971, Geology of the Lake Mountain Northeast Quadrangle, Saguache County, Colorado: Golden, Colorado School of Mines, Master's thesis, 79 p.

174. Bryant, Bruce, 1969, Geologic map of the Maroon Bells Quadrangle, Pitkin and Gunnison Counties, Colorado: U.S. Geological Survey Geologic Quadrangle Map GQ-788, scale 1:24,000.

175. Bryant, Bruce, 1970, Geologic map of the Hayden Peak Quadrangle, Pitkin and Gunnison Counties, Colorado: U.S. Geological Survey Geologic Quadrangle Map GQ-863, scale 1:24,000.

176. Bryant, Bruce, 1971, Geologic map of the Aspen Quadrangle, Pitkin County, Colorado: U.S. Geological Survey Geologic Quadrangle Map GQ-933, scale $1: 24,000$.

177. Bryant, Bruce, 1972, Geologic map of the Highland Peak Quadrangle, Pitkin County, Colorado: U.S. Geological Survey Geologic Quadrangle Map GQ-932, scale $1: 24,000$.

178. Bryant, Bruce, 1972, Map showing areas of selected potential geologic hazards in the Aspen Quadrangle, Pitkin County, Colorado: U.S. Geological Survey Miscellaneous Investigations Series Map I-785-A, scale $1: 24,000$.

179. Bryant, Bruce, 1972, Map showing ground-water potential in the Aspen Quadrangle, Pitkin County, Colorado: U.S. Geological Survey Miscellaneous Investigations Series Map I-785-B, scale 1:24,000.

180. Bryant, Bruce, 1972, Map showing relative permeability of rocks and surficial deposits of the Aspen Quadrangle, Pitkin County, Colorado: U.S. Geological Survey Miscellaneous Investigations Series Map I-785-F, scale $1: 24,000$.

181. Bryant, Bruce, 1972, Map showing types of bedrock and surficial deposits in the Aspen Quadrangle, Pitkin County, Colorado: U.S. Geological Survey Miscellaneous Geologic Investigations Series Map I-785-H, scale 1:24,000.

182. Bryant, Bruce, 1979, Geology of the Aspen 15-Minute Quadrangle, Pitkin and Gunnison Counties, Colorado: U.S. Geological Survey Professional Paper 1073, 146 p.

183. Bryant, Bruce, Beaty, D.W., Thompson, T.B., Sims, P.K., Wallace, S.R., Snow, G.G., Stegen, R.J., Caddy, S.W., and Plumlee, G.S., eds., 1989, Mineral deposits of North America--Volume 1, Mineral deposits and geology of central Colorado, in the collection Field trips for the 28th international geological congress, edited by P.M. Hanshaw: Washington, D.C., American Geophysical Union, $73 \mathrm{p}$.

184. Bryant, Bruce, and Freeman, V.L., 1977, Geologic summary of the Aspen area, southern Rocky Mountains, Colorado, in Veal, H.K., ed., Exploration frontiers of the central and southern Rockies: Denver, Rocky Mountain Association of Geologists field conference [Guidebook], v. 1977, p. 441-449. 
185. Bryant, Bruce, McGrew, L.W., and Wobus, R.A., 1978, Preliminary geologic map of the Denver $1^{\circ}$ by $2^{\circ}$ Quadrangle, north-central Colorado: U.S. Geological Survey Open-File Report 78-397, 20 p.

186. Bryant, Bruce, McGrew, L.W., and Wobus, R.A., 1981, Geologic map of the Denver $1^{\circ}$ by $2^{\circ}$ Quadrangle, north-central Colorado--Sheet 1 , Geology; Sheet 2, Structure: U.S. Geological Survey Miscellaneous Investigations Series Map I-1163, 2 sheets, scale 1:250,000.

187. Burbank, W.S., 1930, Revision of geologic structure and stratigraphy in the Ouray district of Colorado, and its bearing on ore deposition: [Denver?], Colorado Scientific Society Proceedings, v. 12, no. 6, p. 151-232.

188. Burbank, W.S., 1932, Grand Junction to Mesa Verde, in Henderson, C.W., ed., Colorado: International Geological Congress Proceedings, Programme $16, p .27-63$.

189. Burbank, W.S., 1947, Lake City area, Hinsdale County, in Mineral resources of Colorado--Part 2, Summaries of mining districts and mineral deposits: Denver, State of Colorado Mineral Resources Board, p. 439-443.

190. Burbank, W.S., 1947, Eureka and Animas Forks area, San Juan County, in Minera1 resources of Colorado--Part 2, Summaries of mining districts and mineral deposits: Denver, State of Colorado Mineral Resources Board, p. 433-435.

191. Burbank, W.S., 1947, Geologic maps of Uncompahgre (Ouray) district, Colorado: [Washington, D.C.?], U.S. Department of the Interior Press Memo 22231. [Mineral Investigations Preliminary Strategic Map MS-3-217.]

192. Burbank, W.S., Lovering, T.S., Goddard, E.N., and Eckel, E.B., 1935, Geologic map of Colorado: U.S. Geological Survey State Geologic Map, scale 1:500,000. (Reprinted in 1959.)

193. Burbank, W.S., Lovering, T.S., Goddard, E.N., and others, 1967, Geologic map of Colorado: U.S. Geological Survey, scale 1:500,000.

194. Burbank, W.S., and Luedke, R.G., 1964, Geology of the Ironton Quadrangle, Colorado: U.S. Geological Survey Geologic Quadrangle Map GQ-291, scale $1: 24,000$.

195. Burbank, W.S., and Luedke, R.G., 1966, Geologic map of the Telluride Quadrangle, southwestern Colorado: U.S. Geological Survey Geologic Quadrangle Map GQ-504, scale 1:24,000.

196. Burbank, W.S., and Luedke, R.G., 1968, Geology and ore deposits of the western San Juan Mountains, Colorado, in Ore deposits of the United States, 1933-1967, v. 1 [Graton-Sales Volume]: New York, America Institute of Mining, Metallurgical and Petroleum Engineers, p. 714-733.

197. Burns, L.K., Ethridge, F.G., Tyler, Noel, and others, 1980, Geology and uranium evaluation of the Precambrian quartz-pebble conglomerates of the Needle Mountains, southwest Colorado--Final report: U.S. Department of Energy Report GJBX-118-80, 161 p.

198. Burrell, S.D., 1967, Geology of an area southwest of Silverton, San Juan County, Colorado: Boulder, University of Colorado, Master's thesis, $106 \mathrm{p}$.

199. Bush, A.L., 1954, Western San Juan Mountains, Colorado: U.S. Geological Survey Trace Element Investigations Report TEI-440, p. 28-30.

200. Bush, A.L., 1954, Western San Juan Mountains area, Colorado, quadrangle mapping: U.S. Geological Survey Trace Element Investigations Report TEI-490, p. 40-41.

201. Bush, A.L., 1955, Western San Juan Mountains, Colorado, quadrangle mapping: U.S. Geological Survey Trace Element Investigations Report TEI-540, p. 55 . 
202. Bush, A.L., 1955, Western San Juan Mountains, Colorado: U.S. Geological Survey Trace Element Investigations Report TEI-590, p. 31-32.

203. Bush, A.L., 1956, Western San Juan Mountains, Colorado: U.S. Geological Survey Trace Element Investigations Report TEI-620, p. 47-50.

204. Bush, A.L., and Bromfield, C.S., 1966, Geologic map of the Dolores Peak Quadrangle, Dolores and San Miguel Counties, Colorado: U.S. Geological Survey Geologic Quadrangle Map GQ-536, scale 1:24,000.

205. Bush, A.L., Bromfield, C.S., Marsh, 0.T., and Taylor, R.B., 1961, Preliminary geologic map of the Gray Head Quadrangle, San Miguel County, Colorado: U.S. Geological Survey Mineral Investigations Field Studies Map MF-176, scale 1:24,000.

206. Bush, A.L., Bromfield, C.S., and Pierson, C.T., 1956, Preliminary geologic map of the Placerville Quadrangle, Colorado: U.S. Geological Survey Mineral Investigations Field Studies Map MF-96, scale 1:24,000.

207. Bush, A.L., Bromfield, C.S., and Pierson, C.T., 1959, Areal geology of the Placerville Quadrangle, San Miguel County, Colorado: U.S. Geological Survey Bulletin 1072-E, p. 299-384.

208. Bush, A.L., Marsh, 0.T., and Taylor, R.B., 1959, Preliminary geologic map of the Little Cone Quadrangle, San Miguel County, Colorado: U.S.

Geological Survey Mineral Investigations Field Studies Map MF-223, scale $1: 24,000$.

209. Bush, A.L., Marsh, 0.T., and Taylor, R.B., 1960, Areal geology of the Little Cone Quadrangle, Colorado: U.S. Geological Survey Bulletin 1082-G, p. 423-492.

210. Bush, J.H., Jr., 1973, The Upper Cambrian stratigraphy of central Colorado: Pullman, Washington State University, Ph.D. dissertation, unknown pagination.

211. Butler, D.L., 1985, Discharge and water quality of springs in Roan and Parachute Creek basins, northwestern Colorado, 1981-83: U.S. Geological Survey Water-Resources Investigations Report 85-4078, 145 p.

212. Butler, D.L., 1986, General surface- and ground-water quality in a coalresource area near Durango, southwestern Colorado: U.S. Geological Survey Water-Resources Investigations Report 86-4073, 53 p.

213. CER Geonuclear Corporation, 1973, Predetonation Rio Blanco hydrologic testing for period February 1, 1973, to May 1, 1973, in the collection Project Rio Blanco: Las Vegas, Nev., CER Geonuclear Corporation, various pagination.

214. Cadigan, R.A., 1957, Lithologic studies [Colorado]: U.S. Geological Survey Trace Element Investigations Report TEI-690, book 2, p. 354-365.

215. Cadigan, R.A., 1972, Geochemical anomalies and alteration in the Moenkopi Formation, Skul1 Creek, Moffat County, Colorado: U.S. Geological Survey Professional Paper 761,21 p.

216. Cadigan, R.A., 1982, Mineralization and other geologic factors related to the Morrison Formation in particular the northern two-thirds of the Colorado Plateau region--Basic data and factor-analysis results: U.S. Geological Survey Open-File Report 82-1130, 176 p.

217. Cadigan, R.A., Felmlee, J.K., and Rosholt, J.N., 1976, Radioactive mineral springs in Delta County, Colorado: U.S. Geological Survey Open-File Report 76-223, 39 p.

218. Cain, Doug, Helsel, D.R., and Ragone, S.E., 1987, Reconnaissance appraisals of anthropogenic effects on regional ground-water quality, in U.S. Geological Survey program on toxic waste--Ground-water contamination: Technical-Meeting, 3d, Pensacola, Fla., March 23-27, 1987, Proceedings, p. E25-E31. 
219. Cain, H.M., 1947, Cooperative work by U.S. Geological Survey and State of Colorado: Colorado School of Mines Quarterly, v. 42, no. 4, 31 p.

220. Cain, M.R., 1986, Depositional environment of Upper Cretaceous Lewis Sandstones of the Lewis Shale, Sand Wash basin, Colorado, in Stone, D.S., and Johnson, K.S., eds., New interpretations of northwest Colorado geology: Denver, Rocky Mountain Association of Geologists Guidebook, p. 171-181.

221. Calder, L.M., 1988, Chromium contamination of groundwater, in Nriagu, J.0., and Nieboer, Evert, eds., Chromium in the natural and human environments: New York, Wiley, Advances in Science and Technology, v. 20, p. $215-229$.

222. Callihan, M.C., 1980, Engineering report on drilling in the Sand Wash basin, Colorado: U.S. Department of Energy, National Uranium Resource Evaluation Program Report GJBX-125(80), 58 p.

223. Callihan, M.C., 1980, Engineering report on drilling in the Sand Wash basin intermediate grade project: U.S. Department of Energy, National Uranium Resource Evaluation Program Report GJBX-194-80, 51 p.

224. Campbe11, D.L., 1975, Schlumberger electric soundings near Yellow Creek, Piceance Creek basin, Colorado: U.S. Geological Survey Open-File Report 75-354, $28 \mathrm{p}$.

225. Campbe11, D.L., 1977, Electrical soundings near Yellow Creek, Rio Blanco County, Colorado: Journal of Research of the U.S. Geological Survey, v. 5, no. 2 , p. 193-205.

226. Campbell, G.S., 1958, Geology of the Book Cliffs region, Utah and Colorado: [Denver], Rocky Mountain Association of Petroleum Geologists, Rocky Mountain Section, Geology Records, p. 63-69.

227. Campbe11, J.A., 1967, Dispersal patterns in Upper Devonian quartzose sandstones in west-central Colorado, in International symposium on the Devonian system: Alberta, Canada, Alberta Society of Petroleum Geologists, v. 2, p. 1131-1138.

228. Campbel1, J.A., 1972, Lower Paleozoic systems, White River Plateau, in Paleozoic stratigraphy and structural evolution of Colorado: Colorado School of Mines Quarterly, v. 67, no. 4, p. 37-62.

229. Campbel1, J.A., 1972, Petrology of the quartzose sandstone of the Parting Formation in west-central Colorado: Journal of Sedimentary Petrology, v. 42, no. 2, p. 263-269.

230. Campbel1, J.A., 1979, Lower Permian depositional system, northern Uncompahgre basin, in Baars, D.L., ed., Permianland--A field symposiumguidebook of the Four Corners Geological Society: [Durango, Colo.], Four Corners Geological Society, 9th field conference, p. 13-21.

231. Campbell, J.A., 1981, Summary of Paleozoic stratigraphy and history of western Colorado and eastern Utah, in Epis, R.C., and Callender, J.F., eds., Western Slope, Colorado--Western Colorado and eastern Utah: [Socorro?], New Mexico Geological Society Guidebook 32, p. 81-88.

232. Campbel1, M.R., 1923, The Twentymile Park district of the Yampa Coal Field, Routt County, Colorado: U.S. Geological Survey Bulletin 748, $82 \mathrm{p}$.

233. Cannizzaro, C.R., 1985, Depositional analysis of the upper Ismay and lower Desert Creek intervals (Pennsylvanian) of the southern Paradox Basin: Troy, N.Y., Rensselaer Polytechnical Institute, Master's thesis, $175 \mathrm{p}$.

234. Caplan, Allan, 1935, The Miocene lake of Creede, Colorado: Rocks and Minerals, v. 10, no. 10, p. 152-154. 
235. Carpenter, R.H., 1981, Interpretation of water sample analyses, Waunita Hot Springs area, Gunnison County, Colorado, in Zacharakis, T.G., ed., Geothermal resources assessment of Waunita Hot Springs, Colorado: Colorado Geological Survey Special Publication, v. 16, p. 26-30.

236. Carrara, P.E., 1980, Surficial geologic map of the Vernal $1^{\circ}$ by $2^{\circ}$ Quadrangle, Colorado and Utah: U.S. Geological Survey Miscellaneous Investigations Series Map I-1204, scale 1:250,000.

237. Carrara, P.E., Colton, R.B., Holligan, J.A., and Anderson, L.W., 1975, Preliminary map of landslide deposits, Vernal $1^{\circ}$ by $2^{\circ}$ Quadrangle, Colorado and Utah: U.S. Geological Survey Miscellaneous Field Studies Map MF-696, scale 1:250,000. (Reprinted.)

238. Carter, T.E., and Wayland, T.E., 1981, A geologic report on the Sand Wash drilling project, Moffat and Routt Counties, Colorado: U.S. Department of Energy Report GJBX-176(81), 109 p.

239. Carter, W.D., 1955, La Sal Creek area, Paradox district, Montrose County, [Colorado], and San Juan County, Utah: U.S. Geological Survey Trace Element Investigations Report TEI-540, p. 36-38.

240. Carter, W.D., 1956, The Burro Canyon-Dakota contact in the Mt. Peale No. 1 Quadrangle, western Colorado and eastern Utah, in Geology and economic deposits of east-central Utah, 7 th annual field conference: Salt Lake City, Utah, Intermountain Association of Petroleum Geologists, p. 113-115.

241. Carter, W.D., and Gualtieri, J.L., 1956, La Sal Creek area, Montrose County, Colorado, and San Juan County, Utah: U.S. Geological Survey Trace Element Investigations Report TEI-620, p. 57-60.

242. Carter, W.D., and Gualtieri, J.L., 1957, La Sal Creek area, Colorado and Utah: U.S. Geological Survey Trace Element Investigations Report TEI-690, book 1, p. 84-95.

243. Carter, W.D., and Gualtieri, J.L., 1957, Preliminary geologic map of the Mount Peale 1 SE Quadrangle, Montrose County, Colorado, and San Juan County, Utah: U.S. Geological Survey Mineral Investigations Field Studies Map MF-123, scale 1:24,000.

244. Carter, W.D., and Gualtieri, J.L., 1965, Geology and uranium-vanadium deposits of the La Sal Quadrangle, San Juan County, Utah, and Montrose County, Colorado: U.S. Geological Survey Professional Paper 508, 82 p.

245. Carter, W.D., Gualtieri, J.L., and Shoemaker, E.M., 1958, Preliminary geologic map of the Mount Peale $1 \mathrm{NE}$ Quadrangle, San Juan County, Utah, and Montrose County, Colorado: U.S. Geological Survey Mineral Investigations Field Studies Map MF-139, scale 1:24,000.

246. Cary, R.S., Jr., 1960, Structure and stratigraphy of the Horse Mountain Quadrangle, Garfield County, Colorado: Boulder, University of Colorado, Master's thesis, 109 p.

247. Casals, J.F., 1986, Analysis of a landslide along Interstate 70 near Vail, Colorado: Golden, Colorado School of Mines, Master's thesis, $121 \mathrm{p}$.

248. Case, J.E., 1966, Geophysical anomalies over Precambrian rocks, northwestern Uncompahgre Plateau, Utah and Colorado: American Association of Petroleum Geologists Bulletin, v. 50, no. 7, p. 1423-1443.

249. Cashion, W.B., 1969, Geologic map of the Black Cabin Gulch Quadrangle, Rio Blanco County, Colorado: U.S. Geological Survey Geologic Quadrangle Map GQ-812, scale 1:24,000.

250. Cashion, W.B., 1973, Geologic and structure map of the Grand Junction Quadrangle, Colorado and Utah: U.S. Geological Survey Miscellaneous Investigations Series Map I-736, scale 1:250,000. (Reprinted in 1979.) 
251. Cashion, W.B., 1977, Geologic map of the Weaver Ridge Quadrangle, Uintah County, Utah, and Rio Blanco County, Colorado: U.S. Geological Survey Miscellaneous Field Studies Map MF-824, scale 1:24,000.

252. Cashion, W.B., 1978, Geologic map of the Walsh Knolls Quadrangle, Uintah County, Utah, and Rio Blanco County, Colorado: U.S. Geological Survey Miscellaneous Field Studies Map MF-1013, scale 1:24,000.

253. Cashion, W.B., 1983, Descriptions of four stratigraphic sections of parts of the Green River and Uinta Formations in the eastern Uinta Basin, Uintah County, Utah, and Rio Blanco County, Colorado: U.S. Geological Survey Open-File Report 83-17, 44 p.

254. Cashion, W.B., and Brown, J.H., Jr., 1956, Geology of the Bonanza-Dragon oil-shale area, Uintah County, Utah, and Rio Blanco County, Colorado: U.S. Geological Survey $0 i 1$ and Gas Investigations Map OM-153, 2 sheets, scale $1: 62,500$.

255. Cashion, W.B., and Dixon, G.H., 1976, Isopach map and cross section of the Mahogany Zone of the Green River Formation derived principally from geophysical well logs, eastern Uinta Basin, Utah and Colorado: U.S. Geological Survey Miscellaneous Field Studies Map MF-797, scale $1: 250,000$. (Reprinted.)

256. Cashion, W.B., and Donne11, J.R., 1974, Revision of nomenclature of the upper part of the Green River Formation, Piceance Creek basin, Colorado, and eastern Uinta Basin, Utah: U.S. Geological Survey Bulletin 1394-G, $9 \mathrm{p}$.

257. Cashion, W.B., and Roehler, H.W., 1975, Stratigraphic section of part of the Green River Formation and underlying units exposed in Tommys Draw, western Piceance Creek basin, Colorado: U.S. Geological Survey Open-File Report 75-422, 16 p.

258. Caskey, D.J., 1979, Geology and hydrothermal alteration of the Iron Beds area, Hinsdale County, Colorado: Austin, University of Texas, Master's thesis, unknown pagination.

259. Cater, F.W., Jr., 1954, Geology of the Bull Canyon Quadrangle, Colorado: U.S. Geological Survey Geologic Quadrangle Map GQ-33, scale 1:24,000.

260. Cater, F.W., Jr., 1954, Preliminary geologic map of the Gypsum Gap Quadrangle, Colorado: U.S. Geological Survey Mineral Investigations Field Studies Map MF-19, scale 1:24,000.

261. Cater, F.W., Jr., 1954, Preliminary geologic map of the Pine Mountain Quadrangle, Colorado: U.S. Geological Survey Mineral Investigations Field Studies Map MF-20, scale 1:24,000.

262. Cater, F.W., Jr., 1955, Geology of the Gateway Quadrangle, Colorado: U.S. Geological Survey Geologic Quadrangle Map GQ-55, scale 1:24,000.

263. Cater, F.W., Jr., 1955, Geology of the Anderson Mesa Quadrangle, Colorado: U.S. Geological Survey Geologic Quadrangle Map GQ-77, scale $1: 24,000$.

264. Cater, F.W., Jr., 1955, Preliminary geologic map of the Calamity Mesa Quadrangle, Colorado: U.S. Geological Survey Mineral Investigations Field Studies Map MF-32, scale 1:24,000.

265. Cater, F.W., Jr., 1955, Geology of the Calamity Mesa Quadrangle, Colorado: U.S. Geological Survey Geologic Quadrangle Map GQ-61, scale $1: 24,000$.

266. Cater, F.W., Jr., 1955, Geology of the Davis Mesa Quadrangle, Colorado: U.S. Geological Survey Geologic Quadrangle Map GQ-71, scale 1:24,000.

267. Cater, F.W., Jr., 1955, Preliminary geologic map of the Egnar Quadrangle, Colorado: U.S. Geological Survey Mineral Investigations Field Studies Map MF-26, scale $1: 24,000$. 
268. Cater, F.W., Jr., 1955, Geology of the Egnar Quadrangle, Colorado: U.S. Geological Survey Geologic Quadrangle Map GQ-68, scale 1:24,000.

269. Cater, F.W., Jr., 1955, Preliminary geologic map of the Hamm Canyon Quadrangle, Colorado: U.S. Geological Survey Mineral Investigations Field Studies Map MF-21, scale 1:24,000.

270. Cater, F.W., Jr., 1955, Geology of the Hamm Canyon Quadrangle, Colorado: U.S. Geological Survey Geologic Quadrangle Map GQ-69, scale 1:24,000.

271. Cater, F.W., Jr., 1955, Geology of the Horse Range Mesa Quadrangle, Colorado: U.S. Geological Survey Geologic Quadrangle Map GQ-64, scale $1: 24,000$.

272. Cater, F.W., Jr., 1955, Preliminary geologic map of the Joe Davis Hill Quadrangle, Colorado: U.S. Geological Survey Mineral Investigations Field Studies Map MF-27, scale 1:24,000.

273. Cater, F.W., Jr., 1955, Geology of the Joe Davis Hill Quadrangle, Colorado: U.S. Geological Survey Geologic Quadrangle Map GQ-66, scale $1: 24,000$.

274. Cater, F.W., Jr., 1955, Preliminary geologic map of the Naturita NW Quadrangle, Colorado: U.S. Geological Survey Mineral Investigations Field Studies Map MF-30, scale 1:24,000.

275. Cater, F.W., Jr., 1955, Geology of the Pine Mountain Quadrangle, Colorado: U.S. Geological Survey Geologic Quadrangle Map GQ-60, scale $1: 24,000$.

276. Cater, F.W., Jr., Butler, A.P., Jr., and McKay, E.J., 1955, Geology of the Uravan Quadrangle, Colorado: U.S. Geological Survey Geologic Quadrangle Map GQ-78, scale 1:24,000.

277. Cater, F.W., Jr., and Elston, D.P., 1963, Structural development of salt anticlines of Colorado and Utah, in Childs, O.E., and Beebe, B.W., eds., Backbone of the Americas--A symposium: American Association of Petroleum Geologists Memoir 2, p. 152-159.

278. Cater, F.W., Jr., and McKay, E.J., 1955, Preliminary geologic map of the Uravan Quadrangle, Colorado: U.S. Geological Survey Mineral

Investigations Field Studies Map MF-24, scale 1:24,000.

279. Cater, F.W., Jr., and McKay, E.J., 1955, Preliminary geologic map of the Davis Mesa Quadrangle, Colorado: U.S. Geological Survey Mineral Investigations Field Studies Map MF-31, scale 1:24,000.

281. Chalmers, J.R., 1974, Southwestern groundwater law--A textual and bibliographic interpretation: Tucson, University of Arizona, Office of Arid Lands Studies, Arid Lands Resource Information Paper 4, 229 p.

282. Chaney, T.H., Kuhn, Gerhard, Brooks, T.D., and others, 1987, Hydrology of Area 58, Northern Great Plains and Rocky Mountain coal provinces, Colorado and Utah: U.S. Geological Survey Water-Resources Investigations Open-File Report 85-479, 103 p.

284. Chauvenet, Regis, 1890, Analyses of natural, thermal and mineral waters of Colorado: Colorado School of Mines Biennial Report, v. 1890, p. 21-29.

285. Chenoweth, W.L., 1982, The Hayden Survey in the Elk Mountains, in Southeastern Piceance basin, western Colorado: [Grand Junction, Colo.?], Grand Junction Geological Society field trip, Sept. 25-26, 1982, [Guidebook?], p. 95-97.

286. Chew, R.T., III, 1974, Geology, hydrology, and extraction operations at the Occidental Petroleum Corporation oil shale pilot plant near DeBeque, Colorado, in Murray, D.K., ed., Energy resources of the Piceance Creek basin, Colorado: Denver, Rocky Mountain Association of Geologists, 25 th field conference, Guidebook, p. 135-140. 
287. Choate, R., Jurich, D., and Saulnier, G.J., Jr., 1984, Geologic overview, coal deposits, and potential for methane recovery from coalbeds, Piceance basin, Colorado, in Rightmire, C.T., Eddy, G.E., and Kirr, J.N., eds., Coalbed methane resources of the United States: American Association of Petroleum Geologists Studies in Geology 17, p. 223-251.

288. Choate, R., Lent, J., and Rightmire, C.T., 1984, Upper Cretaceous geology, coal, and the potential for methane recovery from coalbeds in San Juan basin, Colorado and New Mexico, in Rightmire, C.T., Eddy, G.E., and Kirr, J.N., eds., Coalbed methane resources of the United States: American Association of Petroleum Geologists Studies in Geology 17, p. 185-222.

289. Christopherson, K.R., 1979, A geophysical study of the Steamboat Springs, Colorado, geothermal systems: Boulder, University of Colorado, Master's thesis, $107 \mathrm{p}$.

290. Chronic, B.J., Jr., 1957, No. 8, McCoy-Burns measured section, in McKee, E.D., ed., Colorado measured sections--A symposium: Denver, Rocky Mountain Association of Geologists, p. 39-45.

291. Chronic, B.J., Jr., and Stevens, C.H., 1958, Pennsylvanian paleogeography in the McCoy area, Eagle County, in Curtis, B.F., ed., Symposium on Pennsylvanian rocks of Colorado and adjacent areas, 1958: Denver, Rocky Mountain Association of Geologists, p. 86-90.

292. Chronic, John, 1961, Selected bibliography for early and middle Paleozoic geology of Colorado, in Berg, R.R., and Rold, J.W., eds., Symposium on Lower and Middle Paleozoic rocks of Colorado, Rocky Mountain Association of Geologists, 12th field conference, 1961: Denver, Rocky Mountain Association of Geologists, p. 201-206.

293. Chronic, John, 1979, Colorado, in The Mississippian and Pennsylvanian (Carboniferous) systems in the United States: U.S. Geological Survey Professional Paper 1110 M-DD, p. V1-V25.

294. Chronic, John, and Matsushita, Hiromi, 1974, Selected bibliography of the geology of northwestern Colorado, with special emphasis on oil shale geology and technology, in Murray, D.K., ed., Energy resources of the Piceance Creek basin, Colorado: Denver, Rocky Mountain Association of Geologists, 25th field conference, Guidebook, p. 261-274.

295. Claassen, H.C., 1984, Geochemical kinetics, in Schneider, Robert, and Trask, N.J., eds., U.S. Geological Survey research in radioactive waste disposal--Fiscal year 1982: U.S. Geological Survey Water-Resources Investigations Report 84-4205, p. 111-112.

296. Claassen, H.C., 1986, Geochemical kinetics, in Dinwiddie, G.A., and Trask, N.J., eds., U.S. Geological Survey research in radioactive waste disposal--Fiscal years 1983, 1984, and 1985: U.S. Geological Survey Water-Resources Investigations Report 87-4009, p. 101-103.

297. Claassen, H.C., Reddy, M.M., and Halm, D.R., 1986, Use of chloride ion in determining hydrologic-basin water budgets--A 3-year case study in the San Juan Mountains, Colorado, USA: Journal of Hydrology, v. 85, no. 1-2, p. 49-71.

298. Clair, J.R., 1952, Paleozoic rocks of the southern Paradox basin, in Wengard, S.A., ed., [1st] geological symposium of the Four Corners region: [Durango, Colo.], Four Corners Geological Society, p. 36-39.

299. Clark, J.H., 1960, Geology of the East Lake Creek area, Eagle County, Colorado: Boulder, University of Colorado, Master's thesis, 71 p. 
300. Clarkson, Gerry, and Reiter, Marsha11, 1988, An overview of geothermal studies in the San Juan basin, New Mexico and Colorado, in Fassett, J.E., ed., Geology and coal-bed methane resources of the northern San Juan Basin, Colorado and New Mexico: [Denver], Rocky Mountain Association of Geologists, p. 285-291.

301. Clift-Eckert, Anne, 1986, Seismotectonic evaluation of the Dudley Gulch graben in the Piceance Creek basin, in Rogers, W.P., and Kirkham, R.M., eds., Contributions to Colorado seismicity and tectonics--A 1986 update: Colorado Geological Survey Special Publication 28, p. 65-74.

302. Cline, C.W., 1957, Stratigraphy of Douglas Creek Member, Green River Formation, Piceance Creek basin, Colorado: Brigham Young University Geology Studies, v. 4, no. 3, 46 p.

303. Clough, G.A., 1951, Structure of Juniper Mountain (Moffat County), Colorado: Boulder, University of Colorado, Master's thesis, $50 \mathrm{p}$.

304. Code, W.E., 1929, Construction of irrigation wells in Colorado: Fort Collins, Colorado State University Agricultural Experiment Station Bulletin 350, p. 1-22.

305. Code, W.E., 1932, Cost of pumping for irrigation water in Colorado: Colorado State University, Agricultural Experiment Station Bulletin 387 , unknown pagination.

306. Coffin, D.L., 1963, Colorado, in McGuiness, C.L., The role of ground water in the national water situtation with State summaries based on reports by district offices of the Ground Water Branch: U.S. Geological Survey Water-Supply Paper 1800, p. 207-225.

307. Coffin, D.L., Welder, F.A., and Glanzman, R.K., 1971, Geohydrology of the Piceance Creek structural basin between the White and Colorado Rivers, northwestern Colorado: U.S. Geological Survey Hydrologic Investigations Atlas HA-370, 2 sheets, scale $1: 125,000$.

308. Coffin, D.L., Welder, F.A., Glanzman, R.K., and Dutton, X.W., 1968, Geohydrologic data from the Piceance Creek basin between the White and Colorado Rivers, northwestern Colorado: Colorado Ground-Water Series Circular $12,38 \mathrm{p}$.

309. Coffin, R.C., 1924, Some anticlines of western Colorado--An anticline in Montezuma County: Colorado Geological Society Bulletin 24, p. 46-55.

310. Cole, R.D., and Sexton, J.L., 1981, Pleistocene surficial deposits of the Grand Mesa area, Colorado, in Epis, R.C., and Callender, J.F., eds., Western Slope, Colorado--Western Colorado and eastern Utah: [Socorro?] New Mexico Geological Society Guidebook 32, p. 121-126.

311. Collins, B.A., 1970, Geology of the coal-bearing Mesaverde Formation (Cretaceous), Coal basin area, Pitkin County, Colorado: Golden, Colorado School of Mines, Master's thesis, $116 \mathrm{p}$.

312. Collins, B.A., 1977, Geology of the Coal basin area, Pitkin County, Colorado, in Veal, H.K., ed., Exploration frontiers of the central and southern Rockies: [Denver], Rocky Mountain Association of Geologists Field Conference [Guidebook], v. 1977, p. 363-377.

313. Collins, L.G., 1953, Structural geology of the Ute Mountains, southwestern Colorado: Urbana, University of Illinois, Bachelor's thesis, $55 \mathrm{p}$.

314. Collins, M.J., 1921, Some anticlines of Moffat County, Colorado:

Boulder, University of Colorado, Master's thesis, $36 \mathrm{p}$.

315. Collins, W.D., and Howard, C.S., 1932, Index of analyses of natural waters in the United States, 1926 to 1931: U.S. Geological Survey Water-Supply Paper 659-C, p. 191-209.

316. Collins, W.D., Lamar, W.L., and Lohr, E.W., 1934, The industrial utility of public water supplies in the United States, 1932: U.S. Geological

Survey Water-Supply Paper 658, $135 \mathrm{p}$. 
317. Colorado Department of Health, 1970, Guidelines for control of water pollution from mine drainage: Denver, Colorado Department of Health.

318. Colorado Geological Survey, 1986, Dowds Junction area, Eagle County, Colorado--Landslide hazard studies, May 1985 to present: Colorado Geological Survey, $36 \mathrm{p}$.

319. Colorado State Planning Office, 1959, Underground water supply, in Colorado year book, 1956-1958: Colorado State Planning Office, p. 461.

320. Colorado State Planning Office, 1962, Springs of Colorado: in Colorado State Planning Office year book 1959-1961: Colorado State Planning Office, p. 470-471.

321. Colton, R.B., Anderson, L.W., Holligan, J.A., Patterson, P.E., and Shaver, K.C., 1975, Preliminary map of landslide deposits, Cortez $1^{\circ}$ by $2^{\circ}$ Quadrangle, Colorado and Utah: U.S. Geological Survey Miscellaneous Field Studies Map MF-699, scale 1:250,000. (Reprinted.)

322. Colton, R.B., Holligan, J.A., and Anderson, L.W., 1975, Preliminary map of landslide deposits, Denver $1^{\circ}$ by $2^{\circ}$ Quadrangle, Colorado: U.S.

Geological Survey Miscellaneous Field Studies Map MF-705, scale $1: 250,000$. (Reprinted.)

323. Colton, R.B., Holligan, J.A., and Anderson, L.W., 1975, Preliminary map of landslide deposits, Durango $1^{\circ}$ by $2^{\circ}$ Quadrangle, Colorado: U.S. Geological Survey Miscellaneous Field Studies Map MF-703, scale $1: 250,000$.

324. Colton, R.B., Holligan, J.A., and Anderson, L.W., 1975, Preliminary map of landslide deposits, Greeley $1^{\circ}$ by $2^{\circ}$ Quadrangle, Colorado: U.S. Geological Survey Miscellaneous Field Studies Map MF-704, scale $1: 250,000$.

325. Colton, R.B., Holligan, J.A., Anderson, L.W., and Patterson, P.E., 1975, Preliminary map of landslide deposits, Leadville $1^{\circ}$ by $2^{\circ}$ Quadrangle, Colorado: U.S. Geological Survey Miscellaneous Field Studies Map MF-701, scale $1: 250,000$. (Reprinted.)

326. Colton, R.B., Holligan, J.A., Anderson, L.W., and Patterson, P.E., 1976, Preliminary map of landslide deposits in Colorado: U.S. Geological Survey Miscellaneous Investigations Series Map I-964, scale 1:500,000.

327. Colton, R.B., Holligan, J.A., Anderson, L.W., and Shaver, K.C., 1975, Preliminary map of landslide deposits, Moab $1^{\circ}$ by $2^{\circ}$ Quadrangle, Colorado and Utah: U.S. Geological Survey Miscellaneous Field Studies Map MF-698, scale $1: 250,000$.

328. Colton, R.B., Holligan, J.A., Patterson, P.E., and Anderson, L.W., 1975, Preliminary map of landslide deposits, Craig $1^{\circ}$ by $2^{\circ}$ Quadrangle,

Colorado: U.S. Geological Survey Miscellaneous Field Studies Map MF-700, scale $1: 250,000$.

329. Colton, R.B., Patterson, P.E., Holligan, J.A., and Anderson, L.W., 1975, Preliminary map of landslide deposits, Montrose $1^{\circ}$ by $2^{\circ}$ Quadrangle,

Colorado: U.S. Geological Survey Miscellaneous Field Studies Map MF-702, scale $1: 250,000$.

330. Comstock, S.S., 1950, Geology of the Monarch and Michael Breen Mining Properties, Ouray County, Colorado: Golden, Colorado School of Mines, Master's thesis, $38 \mathrm{p}$.

331. Comstock, T.B., 1883, Notes on the geology and mineralogy of San Juan County: American Institute of Mining Engineers Transactions, v. 11, p. 165-191.

332. Comstock, T.B., 1886, A remarkable extinct geyser basin in southwestern Colorado: American Naturalist, v. 20, p. 963-965. 
333. Comstock, T.B., 1887, The geology and vein structure of southwestern Colorado: American Institute of Mining Engineers Transations, v. 15, p. 218-265.

334. Comstock, T.B., 1889, Hot spring formations in Red Mountain district, Colorado--A reply to the criticisms of Mr. Emmons: American Institute of Mining Engineers Transactions, v. 17, p. 261-264.

335. Condie, K.C., 1981, Precambrian rocks of southwestern United States and adjacent areas of Mexico: New Mexico Bureau of Mines and Mineral

Resources, Resource Map 13, 2 sheets, scale 1:1,460,640.

336. Condon, S.M., Franczyk, K.J., and Bush, A.L., 1984, Geologic map of the Piedra Wilderness Study Area, Archuleta and Hinsdale Counties, Colorado: U.S. Geological Survey Miscellaneous Field Studies Map MF-1630-B, scale $1: 50,000$.

337. Condon, S.M., and Huffman, A.C., Jr., 1989, Mesozoic and Cenozoic structure and stratigraphy of the San Juan basin--An overview, in Finch, W.I., Huffman, A.C., Jr., and Fassett, J.E., eds., Coal tht of a giant energy-rich basin: Washington, D.C., American Geophysical Union, Field Trip Guidebook.

338. Conley, C.D., 1959, Geology of the Chromo Anticline, Archuleta County, Colorado, and Rio Arriba County, New Mexico: Golden, Colorado School of Mines, Master's thesis, 114 p.

339. Conley, C.D., 1964, Mesaverde Formation at Chromo Anticline, Archuleta County, Colorado: Mountain Geologist, v. 1, no. 1, p. 15-24.

340. Conley, C.D., 1972, Depositional and diagenetic history of the Mississippian Leadville Formation, White River Plateau, Colorado, in Paleozoic stratigraphy and structural evolution of Colorado: Colorado School of Mines Quarterly, v. 67, no. 4, p. 103-135.

341. Connors, R.A., 1975, Geology and alteration of the Crater Creek area, southern San Juan Mountains, Colorado: Golden, Colorado School of Mines, Master's thesis, $57 \mathrm{p}$.

342. Conroy, L.S., 1979, Hydrologic and climatologic data, southeastern Uinta Basin, Utah and Colorado, water year 1977: U.S. Geological Survey OpenFile Report 79-1493, 187 p.

343. Conroy, L.S., 1980, Hydrologic and climatologic data, southeastern Uinta Basin, Utah and Colorado, water year 1978: U.S. Geological Survey OpenFile Report 80-1025, $168 \mathrm{p}$.

344. Conroy, L.S., and Fields, F.K., 1977, Climatologic and hydrologic data, southeastern Uinta Basin, Utah and Colorado, water years 1975 and 1976: Utah Basic-Data Release 29, 244 p.

345. Cook, C.W., 1974, Surface rehabilitation of land disturbances resulting from oil shale development--Final report, Phase I: Fort Collins, Colo., Environmental Resource Center, 160 p.

346. Cooley, M.E., 1979, Depths of channels in the area of the San Juan basin regional uranium study, New Mexico, Colorado, Arizona, and Utah: U.S. Geological Survey Open-File Report 79-1526, 68 p., 26 oversize sheets, scale $1: 250,000$.

347. Cooley, M.E., 1986, Divisions of potential fracture permeability, based on distribution of structures and lineaments, in sedimentary rocks of the Rocky Mountains-High Plains region, Western United States: U.S. Geological Survey Water-Resources Investigations Report 85-4091, scale $1: 2,500,000$.

348. Cooper, J.C., 1955, Cambrian, Devonian and Mississippian rocks of the Four Corners area, in Cooper, J.C., ed., Geology of parts of Paradox, Black Mesa, and San Juan basins, [1st] Four Corners field conference, 1955 [Guidebook]: Four Corners Geological Society, p. 59-65. 
349. Cooper, J.C., ed., 1955, Geology of parts of Paradox, Black Mesa, and San Juan basins, [1st] Four Corners field conference, 1955 [Guidebook]: [Durango, Colo.], Four Corners Geological Society, 217 p.

350. Cooper, L.M., 1983, An evaluation of surface geophysics as applied to a hydrogeologic study in Routt and Jackson Counties, Colorado: Golden, Colorado School of Mines, Master's thesis, $194 \mathrm{p}$.

351. Corbett, M.K., 1966, The geology and structure of the Mt. RichthofenIron Mt. region, north-central Colorado: Mountain Geologist, v. 3, no. 1, p. 3-21.

352. Cordes, E.H., 1969, Hydraulic testing and sampling of USBM-AEC Colorado Core Hole 3, Rio Blanco County, Colorado: U.S. Geological Survey OpenFile Report, $30 \mathrm{p}$.

353. Cornish, Earl, 1967, Ground water: Colorado School of Mines Mineral Industries Bulletin, v. 10, no. 4, 26 p.

354. Covay, K.J., and Tobin, R.L., 1980, Quality of ground water in Routt County, northwestern Colorado: U.S. Geological Survey Open-File Report 80-956, $72 \mathrm{p}$. [Limited copies available from the District Office, USGS, WRD, Room H-2107, Bldg. 53, (Box 25046, Mail Stop 415), Denver Federal Center, Denver, C0 80225.]

355. Craig, L.C., 1953, Colorado Plateau, geologic studies--Introduction: U.S. Geological Survey Trace Element Investigations Report TEI-280, p. 11 .

356. Craig, L.C., 1953, Ground-water studies [Colorado Plateau]: U.S. Geological Survey Trace Element Investigations Report TEI-270, pt. 1, p. 10-11.

357. Craig, L.C., 1981, Lower Cretaceous rocks, southwestern Colorado and southeastern Utah, in Wiegand, D.L., ed., Geology of the Paradox basin: [Denver], Rocky Mountain Association of Geologists field conference [Guidebook], v. 1981, p. 195-200.

358. Craig, L.C., and Cadigan, R.A., 1958, The Morrison and adjacent formations in the Four Corners area, in Sanborn, A.F., ed., Guidebook to the geology of the Paradox basin: Salt Lake City, Intermountain Association of Petroleum Geologists, 9th annual field conference, p. 182-192.

359. Craig, L.C., Holmes, C.N., Freeman, V.L., Mullens, T.E., and Weira, G.W., 1977, Maps showing thickness of the Morrison Formation and thickness and generalized facies of the members of the Morrison Formation in the Colorado Plateau region: U.S. Geological Survey Open-File Report 77-516, 5 sheets, scale 1:1,000,000.

360. Craig, T.W., 1971, Groundwater of the Uncompahgre Valley, Montrose County, Colorado: Rolla, University of Missouri, Master's thesis, $113 \mathrm{p}$.

361. Craigg, S.D., 1988, Analysis of spatial geologic data using surface modeling and geographic information system software--Applications to regional geologic mapping, San Juan structural basin, New Mexico, Colorado, Arizona, and Utah [abs.], in Thomas, H.F. and Biesecker, J.E., cochairmen, Integrating technology and geoscience applications, GIS Symposium, Denver, 1988, abstracts: Washington, D.C., National Academy of Sciences, p. 9.

362. Craigg, S.D., Dam, W.L., Kernodle, J.M., and Levings, G.W., 1989, Hydrogeology of the Dakota Sandstone in the San Juan structural basin, New Mexico, Colorado, Arizona, and Utah: U.S. Geological Survey Hydrologic Investigations Atlas HA-720-I, 2 sheets, scale 1:1,000,000.

363. Crain, H.M., 1945, Publications on work done by the U.S.G.S. in cooperation with State of Colorado: Colorado School of Mines Quarterly, v. 40 , no. 4,28 p. 
364. Crain, H.M., 1948, Guide to the geology of central Colorado: Colorado School of Mines Quarterly, v. 43, no. 2, $176 \mathrm{p}$.

365. Crawford, R.D., and Gibson, Russel1, 1925, Geology and ore deposits of the Red Cliff district, Colorado: Colorado Geological Survey Bulletin 30, $89 \mathrm{p}$.

366. Crawford, R.D., Willson, Kenneth, and Perini, V.C., Jr., 1920, Some anticlines of Routt County, Colorado: Colorado Geological Survey Bulletin 23, $61 \mathrm{p}$.

367. Crews, George, 1963, Geology of a part of northeast Moffat County, Colorado: Golden, Colorado School of Mines, Master's thesis, $124 \mathrm{p}$.

368. Cronoble, J.M., 1969, South Baggs-West Side Canal gas field, Carbon County, Wyoming and Moffat County, Colorado, in Symposium on Tertiary rocks of Wyoming, Wyoming Geological Association, 21st field conference, 1964, Guidebook: Casper, Wyoming Geological Association, Petroleum Information, p. 129-137.

369. Cross, C.W., 1895, The post-Laramie beds of Middle Park, Colorado [with discussion]: Colorado Scientific Society Proceedings, v. 4, p. 192-213.

370. Cross, C.W., 1901, Outline of geology of the Silverton Quadrangle, in Ransome, F.L., A report on the economic geology of the Silverton Quadrangle, Colorado: U.S. Geological Survey Bulletin 182, p. 29-39.

371. Cross, C.W., 1908, The Triassic portion of the Shinarump groups, Powell: Journal of Geology, v. 16, p. 97-123.

372. Cross, C.W., 1911, Geology of area near Lake City, Colorado, in Irving, J.D., and Bancroft, Howland, Geology and ore deposits near Lake City, Colorado: U.S. Geological Survey Bulletin 478, p. 18-32.

373. Cross, C.W., and Hole, A.D., 1910, Description of the Engineer Mountain Quadrangle, Colorado: U.S. Geological Survey Atlas of the United States, Folio $171,14 \mathrm{p}$.

374. Cross, C.W., Howe, Ernest, and Irving, J.D., 1907, Description of the Ouray Quadrangle, Colorado: U.S. Geological Survey Geologic Atlas of the United States, Folio 153, 20 p.

375. Cross, C.W., Howe, Ernest, Irving, J.D., and Emmons, W.H., 1905 , Description of the Needle Mountains Quadrangle, Colorado: U.S. Geological Survey Geologic Atlas of the United States Folio 131, 14 p.

376. Cross, C.W., Howe, Ernest, and Ransome, F.L., 1905, Description of the Silverton Quadrangle, Colorado: U.S. Geological Survey Geologic Atlas of the United States, Folio 120, $34 \mathrm{p}$.

379. Cross, C.W., and Larsen, E.S., Jr., 1935, A brief review of the geology of the San Juan region of southwestern Colorado: U.S. Geological Survey Bulletin 843, $138 \mathrm{p}$.

380. Cross, C.W., and Purington, C.W., 1899, Description of the Telluride Quadrangle, [Colorado]: U.S. Geological Survey Geologic Atlas of the United States, Folio 57, 18 p.

381. Cross, C.W., and Ransome, F.L., 1905, Description of the Rico Quadrangle, [Colorado]: U.S. Geological Survey Geologic Atlas of the United States, Folio $130,20 \mathrm{p}$.

382. Cross, C.W., and Shannon, E.V., 1927, The geology, petrography, and mineralogy of the vicinity of Italian Mountain, Gunnison County, Colorado: U.S. National Museum Proceedings, v. 71, art. 18, 42 p.

383. Cross, C.W., and Spencer, A.C., 1900, Geology of the Rico Mountains: U.S. Geological Survey Annual Report 21 (1899-1900), pt. 2, p. 7-165.

384. Cross, C.W., Spencer, A.C., and Purington, C.W., 1899, Description of La Plata Quadrangle, Colorado: U.S. Geological Survey Geologic Atlas of the United States, Folio $60,14 \mathrm{p}$. 
385. Cruson, M.G., 1973, Geology and ore deposits of the Grizzly Peak cauldron complex, Sawatch Range, Colorado: Golden, Colorado School of Mines, $\mathrm{Ph} . \mathrm{D}$. dissertation, $181 \mathrm{p}$.

386. Cullins, H.L., 1968, Geologic map of the Banty Point Quadrangle, Rio Blanco County, Colorado: U.S. Geological Survey Geologic Quadrangle Map GQ-703, scale 1:24,000.

387. Cullins, H.L., 1969, Geologic map of the Mellen Hill Quadrangle, Rio Blanco and Moffat Counties, Colorado: U.S. Geological Survey Geologic Quadrangle Map GQ-835, scale 1:24,000.

388. Cullins, H.L., 1971, Geologic map of the Rangely Quadrangle, Rio Blanco County, Colorado: U.S. Geological Survey Geologic Quadrangle Map GQ-903, scale $1: 24,000$.

389. Cumella, S.P., 1983, Relation of Upper Cretaceous regressive sandstone units of the San Juan basin to source area tectonics, in Reynolds, M.W., and Dolly, E.D., eds., Mesozoic paleogeography of the west-central United States--Rocky Mountain Paleogeography Symposium 2: Denver, Society of Economic Paleontologists and Mineralogists, Rocky Mountain Section, p. 189-199.

390. Cummings, K.F., and Pott, R.L., 1962, South Craig area, townships 1 to 6 north, ranges 86 to 94 west, Routt, Moffat, Garfield and Rio Blanco Counties, Colorado, in Mott, M.R., and Amuedo, C.L., eds., Exploration for oil and gas in northwestern Colorado: Denver, Rocky Mountain Association of Geologists Guidebook, p. 84-86.

391. Curtis, B.F., 1962, The geologic development of northwestern Colorado, in Mott, M.R., and Amuedo, C.L., eds., Exploration for oil and gas in northwestern Colorado: Denver, Rocky Mountain Association of Geologists Guidebook, p. 15-22.

392. Dale, R.H., and Weeks, J.B., 1978, Hydrologic analysis of the U.S. Bureau of Mines' underground oil-shale research-facility site, Piceance Creek basin, Rio Blanco County, Colorado: U.S. Geological Survey WaterResources Investigations Report 78-28, 35 p. [Available from National Technical Information Service, Springfield, VA 22161, as NTIS Report $\mathrm{PB}-284267$.

393. Dam, W.L., 1987, Methods and preliminary results of geochemical sampling, San Juan basin, New Mexico, Colorado, Arizona, and Utah, in McLean, J.S., and Johnson, A.I., eds., Regional aquifer systems of the United States--Aquifers of the western mountain area: American Water Resources Association Monograph Series 14, p. 203-217.

395. Dana, J.D., 1876, Report on the geology of a portion of Colorado [review]: American Journal of Science Series 3, v. 11, p. 412.

396. Darton, N.H., 1902, Preliminary list of deep borings in the United States, part 1, Alabama-Montana: U.S. Geological Survey Water-Supply Paper $57,60 \mathrm{p}$.

397. Daub, G.J., 1982, Stratigraphy and geology of some coal mines along the North Fork of the Gunnison River, Somerset Coal Field, Colorado, in Southeastern Piceance basin, western Colorado: [Grand Junction, Colo.], Grand Junction Geological Survey Field Trip, Sept. 25-26, 1982, [Guidebook?], p. 69-77.

398. Daub, G.J., Weston, L.K., and Rosar, E.C., 1985, Detailed lithologic, rock quality, and hydrologic data from four drill holes in the central Piceance Creek basin, Rio Blanco County, Colorado, in Gary, J.H., ed., Eighteenth Oil Shale Symposium Proceedings: Golden, Colorado School of Mines Press, p. 21-46. 
399. Daubert, J.T., and Young, R.A., 1982, Ground-water development in western river basins--Large economic gains with unseen costs, in Lehr, J.H., ed., Proceedings of a symposium on ground-water management: Ground Water, v. 20, no. 1, p. 80-85.

400. Davis, P.R., and Prickett, T.A., 1988, Simulating underground mines in a regional model, in FOCUS Conference on Southwestern Ground Water Issues, Albuquerque, N. Mex., 1988, Proceedings: Worthington, Ohio, National Water Well Association, p. 131-144.

401. Davis, W.E., 1951, Electrical resistivity investigations of carnotite deposits in the Colorado Plateau: U.S. Geological Survey [Trace Elements Investigations?] Report TEM-232, 25 p.

402. Day, M.J., Mills, R.A., and Nalven, J.G., 1987, Predicting the influences of post-mining conditions on surface and groundwater resources, in Dworsky, R.F., ed., Proceedings of the symposium on water resources related to mining and energy--Preparing for the future: American Water Resources Association Technical Publication Series TPS 87-4, p. 483-500.

403. Day, M.J., and Perry, H.A., 1985, Hydrogeologic characterization of the Colony Shale 0il Project area, in Gary, J.H., ed., Eighteenth 0il Shale Symposium Proceedings: Golden, Colorado School of Mines Press, p. 58-67.

404. Decker, A.D., Klusman, R., and Horner, D.M., 1987, Geochemical techniques applied to the identification and disposal of connate coal water, in Proceedings of the Coalbed Methane Symposium, Tuscaloosa, Ala., Nov. 16-19, 1987: Golden, Colorado School of Mines, p. 229-242.

405. Decker, D., 1985, Appropriate stratigraphic nomenclature for coal reservoirs in Piceance Basin, Colorado [abs.?], in American Association of Petroleum Geologists Rocky Mountain Section Meeting, Denver, June 2-5, 1985: American Association of Petroleum Geologists Bulletin, v. 69, no. 5, p. 846 .

406. De Voto, R.H., 1980, Mississippian stratigraphy and history of Colorado, in Kent, H.C., and Porter, K.W., eds., Colorado geology: Denver, Rocky Mountain Association of Geologists, p. 57-70.

407. De Voto, R.H., 1980, Pennsylvanian stratigraphy and history of Colorado, in Kent, H.C., and Porter, K.W., eds., Colorado geology: Denver, Rocky Mountain Association of Geologists, p. 71-101.

408. De Voto, R.H., 1985, Field trip no. 6--Sedimentology, dolomitization, mineralization and karstification of the Leadville Limestone (Mississippian), central Colorado, in 1985 SEPM midyear meeting field guides: Denver, Society of Economic Paleontologists and Mineralogists, Rocky Mountain Section, $180 \mathrm{p}$.

409. De Voto, R.H., 1987, Late Paleozoic stratigraphy and syndepositional tectonism, northwestern Colorado [abs.]: Geological Society of America, Abstracts with Programs, v. 19, no. 5, p. 271.

410. De Voto, R.H., 1988, Late Mississippian paleokarst and related mineral deposits, Leadville Formation, central Colorado, in James, N.P., and Choquette, P.W., eds., Paleokarst: New York, Springer-Verlag, p. 278-305.

411. De Voto, R.H., Bartleson, B.L., Schenk, C.J., and Waechter, N.B., 1986, Late Paleozoic stratigraphy and syndepositional tectonism, northwest Colorado, in Stone, D.S., and Johnson, K.S., eds., New interpretations of northwest Colorado geology: Denver, Rocky Mountain Association of Geologists Guidebook, p. 37-49.

412. Deyo, A.E., 1984, Salinity investigations of Mancos landforms and springs in the Upper Colorado River Basin: Berkeley or Los Angeles, University of California, Ph.D. dissertation, $200 \mathrm{p}$. 
413. Dickinson, R.G., 1965, Geologic map of the Cerro Summit Quadrangle, Montrose County, Colorado: U.S. Geological Survey Geologic Quadrangle Map GQ-486, scale 1:24,000.

414. Dickinson, R.G., 1987, Geologic map of the Buckhorn Lakes Quadrangle, Gunnison, Montrose, and Ouray Counties, Colorado: U.S. Geological Survey Geologic Quadrangle Map GQ-1642, scale $1: 24,000$.

415. Dickinson, R.G., 1987, Geologic map of the Washboard Rock Quadrangle, Gunnison, Montrose, and Ouray Counties, Colorado: U.S. Geological Survey Geologic Quadrangle Map GQ-1643, scale 1:24,000.

416. Dickinson, R.G., 1988, Geologic map of the Courthouse Mountain Quadrangle, Gunnison, Hinsdale, and Ouray Counties, Colorado: U.S. Geological Survey Geologic Quadrangle Map GQ-1644, scale 1:24,000.

417. Di Giambattista, C.D., 1952, Regional stratigraphy of the Four Corners area, in Wengard, S.A., ed., [1st] Geological symposium of the Four Corners region: [Durango, Colo.], Four Corners Geological Society, p. 6-9.

418. Dings, M.G., 1953, Radiometric reconnaissance near Montezuma, Summit County, Colorado: U.S. Geological Survey Trace Element Investigations Report TEI-296, pt. 1, 13 leaves.

419. Dings, M.G., Robinson, C.S., and Brock, M.R., 1952, Geologic map of Garfield Quadrangle, Colorado: U.S. Geological Survey Open-File Report, scale unknown.

420. Dings, M.G., and Schafer, Max, 1953, Radiometric reconnaissance in the Garfield and Taylor Park Quadrangles, Chaffee and Gunnison Counties, Colorado: U.S. Geological Survey Trace Element Investigations Report TEI-255, pt. 1,25 p.

421. Dobyns, D.R., 1950, Geophysical exploration in the San Juan basin [abs.?], in Guidebook of the San Juan basin, New Mexico and Colorado--New Mexico Geological Society, 1st field conference, 1950: Socorro, New Mexico Geological Society, p. 132.

422. Dockal, J.A., 1980, Petrology and sedimentary facies of Redwall Limestone (Mississippian) of Uinta Mountains, Utah and Colorado: Iowa City, University of Iowa, Ph.D. dissertation, $440 \mathrm{p}$.

423. Doelger, N.M., 1987, The stratigraphy of the Nugget Sandstone, in Miller, W.R., ed., The thrust belt revisited, Wyoming Geological Association, 38th field conference, Jackson Hole, Wyo., Sept. 8-11, 1987: Wyoming Geological Association Guidebook 38, p. 163-178.

424. Donnel1, J.R., 1954, Tongue of Weber Sandstone in Maroon Formation near Carbondale and Redstone, northwestern Colorado: American Association of Petroleum Geologists Bulletin, v. 38, no. 8, p. 1817-1821.

425. Donnell, J.R., 1958, The Weber Sandstone in the White River Uplift, in Curtis, B.F., ed., Symposim on Pennsylvanian rocks of Colorado and adjacent areas, 1958: Denver, Rocky Mountain Association of Geologists, p. $95-98$.

426. Donnel1, J.R., 1959, Mesaverde stratigraphy in the Carbondale area, northwestern Colorado, in Haun, J.D., and Weimer, R.J., eds., Symposium on Cretaceous rocks of Colorado and adjacent areas--Rocky Mountain Association of Geologists, 11th field conference, Washakie, Sand Wash, and Piceance basins, 1959: Denver, Rocky Mountain Association of Geologists, p. 76-77.

427. Donnell, J.R., 1961, Tripartition of the Wasatch Formation near De Beque in northwestern Colorado, article 61, in Short papers in the geologic and hydrologic sciences: U.S. Geological Survey Professional Paper 424-B, p. B147-B148. 
428. Donnell, J.R., 1964, Geology and oil-shale resources of the Green River Formation, in First symposium on oil shale: Colorado School of Mines Quarterly, v. 59, no. 3, p. 153-163.

429. Donnell, J.R., 1982, Preliminary geologic map of the Sagebrush Hill Quadrangle, Rio Blanco County, Colorado: U.S. Geological Survey Miscellaneous Field Studies Map MF-1398, scale 1:24,000.

430. Donnell, J.R., 1982, Tongues of the Green River and Uinta Formations in the Piceance Creek basin, in Gary, J.H., ed., Fifteenth Oil Shale Symposium Proceedings: Golden, Colorado School of Mines Press, p. 29-37.

431. Donnel1, J.R., Cashion, W.B., and Brown, J.H., Jr., 1953, Geology of the Cathedral Bluffs oil-shale area, Rio Blanco and Garfield Counties, Colorado: U.S. Geological Survey Oil and Gas Investigations Map OM-134, scale 1:95,040.

432. Donnell, J.R., Yeend, W.E., and Smith, M.C., 1984, Preliminary geologic map of the Mesa Quadrangle, Mesa County, Colorado: U.S. Geological Survey Miscellaneous Field Studies Map MF-1698, scale 1:24,000.

433. Donnel1, J.R., Yeend, W.E., and Smith, M.C., 1985, Preliminary geologic map of the Collbran Quadrangle, Mesa County, Colorado: U.S. Geological Survey Miscellaneous Field Studies Map MF-1825, scale 1:24,000.

434. Donnel1, J.R., Yeend, W.E., and Smith, M.C., 1985, Preliminary geologic map of the Molina Quadrangle, Mesa County, Colorado: U.S. Geological Survey Miscellaneous Field Studies Map MF-1784, scale 1:24,000.

435. Donnell, J.R., Yeend, W.E., and Smith, M.C., 1986, Preliminary geologic map of the Grand Valley Quadrangle, Garfield County, Colorado: U.S. Geological Survey Miscellaneous Field Studies Map MF-1883, scale 1:24,000.

436. Donne11, J.R., Yeend, W.E., and Smith, M.C., 1987, Geologic map of the Housetop Mountain Quadrangle, Garfield and Mesa Counties, Colorado: U.S. Geological Survey Miscellaneous Field Studies Map MF-1965, scale $1: 24,000$.

437. Donnell, J.R., Yeend, W.E., and Smith, M.C., 1988 [1987], Geologic map of the Hawxhurst Creek Quadrangle, Garfield and Mesa Counties, Colorado: U.S. Geological Survey Miscellaneous Field Studies Map MF-2026, scale $1: 24,000$.

438. Donnell, J.R., Yeend, W.E., and Smith, M.C., 1989, Geologic map of the North Mamm Peak Quadrangle, Garfield County, Colorado: U.S. Geological Survey Miscellaneous Field Studies Map MF-2093, scale 1:24,000.

439. Donner, H.F., 1949, Geology of the McCoy area, Eagle and Routt Counties, Colorado: Geological Society of America Bulletin, v. 60, no. 8, p. 1215-1248.

440. Dreesen, D.R., Williams, J.M., Marple, M.L., Gladney, E.S., and Perrin, D.R., 1982, Mobility and bioavailability of uranium mill tailings contaminants: Environmental Science and Technology, v. 16, no. 10, p. 702-709.

441. Driese, S.G., 1984, Sedimentology of interdune carbonates, Weber Sandstone (Pennsylvanian-Permian), northern Utah and Colorado [abs.?], in Society of Economic Paleontologists and Mineralogists, Annual Midyear Meeting, 1st, San Jose, Calif., Aug. 10-13, 1984: [Tulsa, Okla.], Society of Economic Paleontologists and Mineralogists Proceedings 1 , p. 27.

442. Driver, N.E., Norris, J.M., Kuhn, Gerhard, and others, 1984, Hydrology of Area 53, Northern Great Plains and Rocky Mountains coal provinces, Colorado, Wyoming, and Utah: U.S. Geological Survey Water-Resources Investigations Open-File Report 83-765, 93 p. 
443. Druitt, C.E., 1975, Geographic and geologic setting for energy fuels field course and workshop, in Johnson, K.S., instructor, Energy fuels field course and workshop--Exploring the Colorado Plateau and the Rocky Mountain area of Colorado and Utah: Norman, University of Oklahoma, Geological Engineering Field Project, 1975, p. 1-18.

444. Duba, A., Piwinskii, A.J., Santor, M., and others, 1978, The electrical conductivity of sandstone, limestone and granite: Royal Astronomical Society Geophysical Journal, v. 53, no. 3, p. 583-597.

445. Dubiel, R.F., Good S.C., and Parrish, J.M., 1989, Sedimentology and paleontology of the Upper Triassic Chinle Formation, Bedrock, Colorado: Mountain Geologist, v. 26, no. 4, p. 113-126.

446. Dubiel, R.F., and Skipp, Gary, 1989, Stratigraphic and sedimentologic studies of the Upper Triassic Chinle Formation, western Colorado: U.S. Geological Survey Open-File Report 89-2, 26 p.

447. Duffy, C.J., 1984, Conceptual models of geologic and agricultural salt loads in streams of the Upper Colorado River Basin, in French, R.H., ed., Salinity in watercourses and reservoirs--International Symposium on State-of-the-Art Control of Salinity, Salt Lake City, July 13-15, 1983, Proceedings: Boston, Butterworth Publishers, p. 223-233.

448. Duffy, C.J., Jurinak, J.J., Sangani, S., and Azimi, A., 1985, Identification and modeling the impact of marine shale bedrock on ground water and stream salinity--Upper Colorado River Basin: Logan, Utah Center for Water Resources Research Program Report G-936-02, 104 p.

449. Duke, H.R., 1967, Colorado ground-water levels, spring 1967: Fort Collins, Colorado State University Experiment Station CER66-67HRD54, 2 sheets, scale: 1 inch equals 5 miles.

450. Duke, H.R., and Skinner, M.M., 1965, Colorado ground-water levels, spring 1965: Fort Collins, Colorado State University Experiment Station. CER65HRD-MMS29, 2 sheets, scale: 1 inch equals 5 miles.

451. Duke, H.R., and Sundaram, A.V., 1966, Colorado ground-water levels, spring 1966: Fort Collins, Colorado State University Experiment Station CER66HRD15, unknown pagination.

452. Duncan, D.C., 1976, Preliminary geologic map of Wolf Ridge Quadrangle, Rio Blanco County, Colorado: U.S. Geological Survey Miscellaneous Field Studies Map MF-753, scale 1:24,000.

453. Duncan, D.C., 1976, Preliminary geologic map of Square S Ranch Quadrangle, Rio Blanco County, Colorado: U.S. Geological Survey Miscellaneous Field Studies Map MF-754, scale 1:24,000.

454. Duncan, D.C., 1976, Preliminary geologic map of Greasewood Gulch Quadrangle, Rio Blanco County, Colorado: U.S. Geological Survey Miscellaneous Field Studies Map MF-755, scale 1:24,000.

455. Duncan, D.C., 1976, Preliminary geologic map of Jessup Gulch Quadrangle, Rio Blanco County, Colorado: U.S. Geological Survey Miscellaneous Field Studies Map MF-756, scale 1:24,000.

456. Duncan, D.C., 1976, Preliminary geologic map of Rock School Quadrangle, Rio Blanco County, Colorado: U.S. Geological Survey Miscellaneous Field Studies Map MF-757, scale 1:24,000.

457. Duncan, D.C., 1976, Preliminary geologic map of Yankee Gulch Quadrangle, Rio Blanco County, Colorado: U.S. Geological Survey Miscellaneous Field Studies Map MF-758, scale 1:24,000.

458. Duncan, D.C., and Belser, Carl, 1950, Geology and oil-shale resources of the eastern part of the Piceance Creek basin, Rio Blanco and Garfield Counties, Colorado: U.S. Geological Survey Oil and Gas Investigations Map OM-119, scale $1: 96,000$. 
459. Duncan, D.C., and Denson, N.M., 1949, Geology of Naval Oil Shale Reserves 1 and 3, Garfield County, Colorado: U.S. Geological Survey Oil and Gas Investigations Map 0M-94, 2 sheets, scale 1:31,680.

460. Duncan, D.C., Hail, W.J., Jr., O'Sullivan, R.B., and Pipiringos, G.N., 1974, Four newly named tongues of Eocene Green River Formation, northern Piceance Creek basin, Colorado: U.S. Geological Survey Bulletin 1394-F, $13 \mathrm{p}$.

461. Dunrud, C.R., 1989, Geologic map and coal stratigraphic framework of the Cedaredge area, Delta County, Colorado: U.S. Geological Survey Coal Investigations Map C-116, scale 1:50,000.

462. Dunrud, C.R., 1989, Geologic map and coal stratigraphic framework of the Paonia area, Delta and Gunnison Counties, Colorado: U.S. Geological Survey Coal Investigations Map C-115, 2 sheets, scale 1:50,000.

463. Durfor, C.N., and Becker, Edith, 1964, Chemical quality of public water supplies of the United States and Puerto Rico, 1962, shown as Statewide averages, mainly in graphic and tabular form: U.S. Geological Survey Hydrologic Investigations Atlas HA-200, scale [variable?].

464. Dyni, J.R., 1966, Geologic map of the Thornburg oil and gas field and vicinity, Moffat and Rio Blanco Counties, Colorado: U.S. Geological Survey Oil and Gas Investigations Map OM-216, scale 1:24,000. [Accompanied by 7-page text]

465. Dyni, J.R., 1968, Geologic map of the Elk Springs Quadrangle, Moffat County, Colorado: U.S. Geological Survey Geologic Quadrangle Map GQ-702, scale $1: 62,500$.

466. Dyni, J.R., 1974, Stratigraphy and nahcolite resources of the saline facies of the Green River Formation, Rio Blanco County, Colorado: U.S. Geological Survey Open-File Report 74-56, 28 p.

467. Dyni, J.R., 1979, Lithologic description of drill core from Sinclair 0il Company Skyline corehole 1, Piceance Creek basin, Rio Blanco County, Colorado: U.S. Geological Survey Open-File Report 79-1222, 28 p.

468. Dyni, J.R., 1980, Selected field notes and radiometric data on the Browns Park Formation in the Elk Springs Quadrangle, Moffat County, Colorado: U.S. Geological Survey Open-File Report 80-526, 1 oversize sheet.

469. Dyni, J.R., and Cullins, H.L., 1965, Meeker and Loyd Sandstone Members of the Mancos Shale, Moffat and Rio Blanco Counties, Colorado: U.S. Geological Survey Bulletin 1194-J, p. J1-J7.

470. Dyni, J.R., and Hawkins, J.E., 1981, Lacustrine turbidites in the Green River Formation, northwestern Colorado: Geology (Boulder), v. 9, no. 5, p. 235-238.

471. Eager, G.P., 1978, Geophysical logs of coal test drill holes in the Grand Mesa Coal Field, Delta and Mesa Counties, Colorado: U.S. Geological Survey Open-File Report 78-540, 97 p.

472. Eager, G.P., 1979, Geophysical logs of coal test drill holes in the Grand Mesa Coal Field, Delta County, Colorado: U.S. Geological Survey OpenFile Report 79-327, 21 p.

473. Eakins, L.G., 1890, Efflorescence of sandstone, from Cliff Creek, Gunnison County, in Clarke, F.W., Chief Chemist, Report of work done in the division of chemistry and physics, mainly during the fiscal year 1887-88: U.S. Geological Survey Bulletin 60, p. 170.

474. Eberly, L.D., 1953, The geology of the Baldy Mountain area, La Plata County, Colorado: Urbana, University of Illinois, Master's thesis, 67 p.

475. Eckel, E.B., 1936, Resurvey of the geology and ore deposits of the La Plata mining district, Colorado: [Denver?], Colorado Scientific Society Proceedings, v. 13, no. 9, p. 508-547. 
477. Eckel, E.B., Williams, J.S., Galbraith, F.W, III, and others, 1968, Geology and ore deposits of the La Plata district, Colorado [summary], in Shomaker, John, ed., Guidebook of San Juan-San Miguel-La Plata region, New Mexico and Colorado--New Mexico Geological Society, 19th field conference, 1968: Socorro, New Mexico Bureau of Mines and Minera1 Resources, p. 41-62.

478. Eckel, E.B., 1949, Geology and ore deposits of the La Plata district, Colorado, with sections by J.S. Williams, F.W. Galbraith, III, and others: U.S. Geological Survey Professional Paper 219, 179 p.

479. Edwards, J., Jr., 1966, The petrology and structure of the buried Precambrian basement of Colorado: Colorado School of Mines Quarterly, v. 61 , no. $4,436 \mathrm{p}$.

480. Edwards, J., Jr., 1966, The petrology and structure of the buried Precambrian basement of Colorado: Golden, Colorado School of Mines, Ph.D. dissertation, 2 v., 248 p.; 74 p.

482. Effinger, W.L., 1934, A report on the geology of Rocky Mountain National Park: [Washington, D.C.?], National Park Service, 28 p.

483. Eicher, L.J., Hedlund, D.C., and Miller, G.A., 1957, Preliminary geologic map and sections of the western part of the Gateway district, Mesa County, Colorado, and Grand County, Utah: U.S. Geologica1 Survey Mineral Investigations Field Studies Map MF-122, scale 1:24,000.

484. Eisel, L.M., 1981, The national ground water picture, in Proceedings of the Thirteenth biennial conference on ground water [Irvine, Calif., Sept. 14-15, 1981]: California Water Resources Center Report 53, p. 33-38.

485. Eisenmenger, K.K., 1986, Seismic stratigraphic study of the Lower Cretaceous Dakota Group, Douglas Creek Arch, western Colorado: Golden, Colorado School of Mines, Master's thesis, $76 \mathrm{p}$.

486. Ekren, E.B., 1955, Ute Mountains, Colorado: U.S. Geological Survey Trace Element Investigations Report TEI-590, p. 32-33.

487. Ekren, E.B., and Houser, F.N., 1956, Ute Mountains, Colorado: U.S. Geological Survey Trace Element Investigations Report TEI-620, p. 50-52.

488. Ekren, E.B., and Houser, F.N., 1956, Ute Mountains, Colorado: U.S. Geological Survey Trace Element Investigations Report TEI-640, p. 50-51.

489. Ekren, E.B., and Houser, F.N., 1957, Preliminary geologic map of the Sentinel Peak NW Quadrangle, Montezuma County, Colorado: U.S. Geological Survey Mineral Investigations Field Studies Map MF-132, scale 1:24,000.

490. Ekren, E.B., and Houser, F.N., 1957, Ute Mountains, Colorado: U.S. Geological Survey Trace Element Investigations Report TEI-690, book 1, p. 71-75.

491. Ekren, E.B., and Houser, F.N., 1958, Stratigraphy and structure of the Ute Mountains, Montezuma County, Colorado, in Sanborn, A.F., ed., Guidebook to the geology of the Paradox basin: Salt Lake City, Intermountain Association of Petroleum Geologists, 9th annual field conference, p. 74-77.

492. Ekren, E.B., and Houser, F.N., 1958, Ute Mountains, Colorado: U.S. Geological Survey Trace Element Investigations Report TEI-740, p. 21-29.

493. Ekren, E.B., and Houser, F.N., 1959, Preliminary geologic map of the Cortez SW Quadrangle, Montezuma County, Colorado: U.S. Geological Survey Mineral Investigations Field Studies Map MF-217, scale 1:24,000.

494. Ekren, E.B., and Houser, F.N., 1959, Preliminary geologic map of the Moqui SE Quadrangle, Montezuma County, Colorado: U.S. Geological Survey Mineral Investigations Field Studies Map MF-221, scale 1:24,000. 
495. Ekren, E.B., and Houser, F.N., 1959, Preliminary geologic map of the Sentinel Peak NE Quadrangle, Montezuma County, Colorado: U.S. Geological Survey Mineral Investigations Field Studies Map MF-224, scale 1:24,000.

496. Ekren, E.B., and Houser, F.N., 1959, Relations of Lower Cretaceous and Upper Jurassic rocks, Four Corners area, Colorado: American Association of Petroleum Geologists Bulletin, v. 43, no. 1, p. 190-201.

497. El-Ashry, M.T., 1980, Ground-water salinity problems related to irrigation in the Colorado River basin: Ground Water, v. 18, no. 1, p. 37-45.

498. Elias, D.W., 1959, Cretaceous section exposed in the Spring Creek area, Moffat County, Colorado, in Haun, J.D., and Weimer, R.J., eds., Symposium on Cretaceous rocks of Colorado and adjacent areas--Rocky Mountain Association of Geologists, 11th field conference, Washakie, San Wash, and Piceance basins, 1959: Denver, Rocky Mountain Association of Geologists, p. 74-75.

499. Ellis, E.G., 1976, Surficial and environmental geology of part of the Upper Williams Fork River basin, Colorado: Boulder, University of Colorado, Master's thesis, $66 \mathrm{p}$.

500. Ellis, M.S., and Freeman, V.L., 1984, Geologic map and cross sections of the Carbondale 30- by 60-Minute Quadrangle, west-central Colorado: U.S. Geological Survey Coal Investigations Map C-97-A, scale 1:100,000.

501. Ellis, M.S., Freeman, V.L., and Donnell, J.R., 1988, Cross sections showing correlation of coal beds and coal zones in the Mesaverde Formation in the Carbondale 30- by 60-Minute Quadrangle, west-central Colorado: U.S. Geological Survey Coal Investigations Map C-97-B, 2 sheets, scale 1:100,000.

502. Ellis, M.S., and Gabaldo, Virginia, 1989, Geologic map and cross sections of parts of the Grand Junction and Delta 30- by 60-Minute Quadrangles, west-central Colorado: U.S. Geological Survey Coal Investigations Map C-124, scale 1:100,000.

503. Ellis, M.S., Gaskill, D.L., and Dunrud, C.R., 1987, Geologic map of the Paonia and Gunnison area, Delta and Gunnison Counties, Colorado: U.S. Geological Survey Coal Investigations Map C-109, scale 1:100,000.

504. Ellis, M.S., and Hopeck, J.T., 1982, Geologic map of parts of Bitter Creek Well, Harley Dome, Westwater $4 \mathrm{SE}$, and Westwater 4 SW Quadrangles, Colorado and Utah, showing coal beds in Dakota Sandstone and adjacent rocks: U.S. Geological Survey Open-File Report 82-741, scale 1:50,000.

505. Ellis, M.S., and Hopeck, J.T., 1985, Geologic map showing coal beds in the Dakota Sandstone, Harley Dome Quadrangle, and parts of the Bitter Creek Well, Westwater $4 \mathrm{SE}$, and Westwater $4 \mathrm{SW}$ Quadrangles, Colorado and Utah: U.S. Geological Survey Miscellaneous Field Studies Map MF-1800, scale 1:50,000.

506. Ellis, M.S., and Kelso, B.S., 1987, Cross sections showing stratigraphic framework of Upper Cretaceous Dakota Sandstone, Mancos Shale, Mesaverde Group, and Mesaverde Formation, and lower Tertiary Wasạtch Formation, west-central Piceance basin, Garfield County, Colorado: U.S. Geological Survey Miscellaneous Field Studies Map MF-2008-A, 2 sheets, scale not listed.

507. Ellis, S.R., and Mann, P.G., 1981, Effects of effluents from a coal-fired electric-generating powerplant on local ground water near Hayden, Colorado: U.S. Geological Survey Water-Resources Investigations Open-File Report 81-1196, 153 p.

508. Elmore, R.T., 1955, Geology of the Jack's Cabin area of Gunnison County, Colorado: Lexington, University of Kentucky, Master's thesis, $35 \mathrm{p}$. 
509. Emery, P.A., 1970, Electric analog model evaluation of a water-salvage plan, San Luis Valley, south-central Colorado: Colorado Water Conservation Board Circular 14, 11 p.

510. Emmons, S.F., 1894, Description of the Elk Mountains, in Emmons, S.F., Cross, C.W., and Eldridge, G.H., Description of the Anthracite-Crested Butte Quadrangle, Colorado: U.S. Geological Survey Geologic Atlas of the United States, Folio 9, p. 1-3.

511. Emmons, S.F., 1898, Description of the Tenmile district Quadrangle, [Colorado]: U.S. Geological Survey Geologic Atlas of the United States, Folio $48,6 \mathrm{p}$.

512. Emmons, S.F., 1907, Uinta Mountains: Geological Society of America Bulletin, v. 18, p. 287-302.

513. Emmons, S.F., Cross, C.W., and Eldridge, G.H., 1894, Description of the Anthracite-Crested Butte Quadrangle, Colorado: U.S. Geological Survey Geologic Atlas of the United States, Folio 9, $11 \mathrm{p}$.

514. Emmons, W.H., and Larsen, E.S., Jr., 1913, A preliminary report on the geology and ore deposits of Creede, Colorado, in Lindgren, Waldemar, chief geologist, Contributions to economic geology--Part 1, metals and nonmetals, except fuels: U.S. Geological Survey Bulletin 530, p. 42-65.

515. Emmons, W.H., and Larsen, E.S., Jr., 1913, The hot springs and the mineral deposits of Wagon Wheel Gap, Colorado: Economic Geology, v. 8, p. 235-246.

516. Emmons, W.H., and Larsen, E.S., Jr., 1923, Geology and ore deposits of the Creede district, Colorado: U.S. Geological Survey Bulletin 718, $198 \mathrm{p}$.

517. Endlich, F.M., 1876, Report on the San Juan district, Colorado: U.S. Geological and Geographical Survey of the Territories (Hayden) Annual Report 8, p. 181-240.

518. Endlich, F.M., 1877, Report of the geology of the White River district: American Naturalist, v. 11, p. 81-82.

519. Endlich, F.M., 1877, Report on southern Colorado: U.S. Geological and Geographical Survey of the Territories (Hayden) Annual Report 9, p. 103-235.

520. Endlich, F.M., 1878, On the geology of the White River district: U.S. Geological and Geographical Survey of the Territories (Hayden) Annual Report 10, p. 61-131.

521. Epis, R.C., and Callender, J.F., eds., 1981, Western Slope, Colorado-Western Colorado and eastern Utah: [Socorro?], New Mexico Geological Society Guidebook 32, $337 \mathrm{p}$.

522. Epis, R.C., and Weimer, R.J., eds., 1976, Studies in Colorado field geology--Geological Society of America annual meeting, Denver, Nov. 8-11, 1976: Professional Contributions of Colorado School of Mines 8, 552 p.

523. Eppinger, R.G., Theobald, P.K., and Carlson, R.R., 1984, Preliminary geologic map of the western and southern parts of the Byers Peak, the northwestern part of the Loveland Pass, and the eastern part of the Ute Peak 7 1/2-Minute Quadrangles, Clear Creek and Grand Counties, Colorado: U.S. Geological Survey Open-File Report 84-274.

524. Eppinger, R.G., Theobald, P.K., and Carlson, R.R., 1985, Generalized geologic map of the Vasquez Peak Wilderness Study Area and the Williams Fork and St. Louis Peak Roadless Areas, Clear Creek, Grand, and Summit Counties, Colorado: U.S. Geological Survey Miscellaneous Field Studies Map MF-1588-B, scale 1:50,000. 
525. Ethridge, F.G., Sunada, D.K., Tyler, Noel, and Andrews, Sarah, 1982, Field, model, and computer simulation study of some aspects of the origin and distribution of Colorado Plateau-type uranium deposits: U.S. Geological Survey Open-File Report 82-589, 56 p.

526. Evangelou, V.P., Whittig, L.D., and Tanji, K.K., 1984, Dissolved mineral salts derived from Mancos Shale: Journal of Environmental Quality, v. 13, no. 1 , p. 146-150.

527. Evans, J.L., 1973, Geology of the upper Marshall Creek drainage basin, Saguache County, Colorado: Golden, Colorado School of Mines, Master's thesis, $78 \mathrm{p}$.

528. Evans, W.C., Presser, T.S., and Barnes, Ivan, 1987, Selected soda springs of Colorado and their origins, in Subitzky, Seymour, ed., Selected papers in the hydrologic sciences, 1986: U.S. Geological Survey Water-Supply Paper 2310, p. 45-52.

529. F.M. Fox \& Associates, 1973, Engineering geology report for Planning District 9, State of Colorado: Colorado Geological Survey, Environmental Geology 4, 22 p.

530. F.M. Fox \& Associates, Olander, H.C., Lamm, N.B., and others, 1974, Roaring Fork and Crystal Valleys--An environmental and engineering geology study--Eagle, Garfield, Gunnison and Pitkin Counties, Colorado: [Denver?], Colorado Geological Survey, Environmental Geology 8, 30 p.

531. Fairer, G.M., 1971, Geology of the Granby Quadrangle, Grand County, Colorado: Golden, Colorado School of Mines, Master's thesis, 54 p.

532. Fassett, J.E., 1977, Geology of the Point Lookout, Cliff House and Pictured Cliffs Sandstones of the San Juan basin, New Mexico and Colorado: in Fassett, J.E., ed., Guidebook of San Juan basin III, northwestern New Mexico [Socorro?], New Mexico Geological Society 28th field conference, 1977, p. 193-197.

533. Fassett, J.E., 1984, Significance of the rate of deposition of uppermost Upper Cretaceous rocks of the San Juan basin, New Mexico and Colorado [abs.]: Geological Society of America Rocky Mountain Section Abstracts with Programs, v. 16, no. 4, p. 221.

534. Fassett, J.E., 1984, Late Cretaceous coal deposition in the San Juan basin, New Mexico and Colorado [abs.]: Geological Society of America Abstracts with Programs, v. 16, no. 6, p. 506.

535. Fassett, J.E., 1985, Early Tertiary paleogeography and paleotectonics of the San Juan basin area, New Mexico and Colorado, in Flores, R.M., and Kaplan, S.S., eds., Cenozoic paleogeography of the west-central United States: Denver, Rocky Mountain Section, Society of Economic Paleontologists and Mineralogists Proceedings, p. 317-334.

536. Fassett, J.E., 1987, Geometry and depositional environments of Fruitland Formation coalbeds, San Juan basin, New Mexico and Colorado--Anatomy of a giant coalbed methane deposit, in U.S. Geological Survey 1987 Coalbed Methane Symposium, Tuscaloosa, Ala., Nov. 16-19, 1987, Proceedings: p. 19-35.

537. Fassett, J.E., 1987, The ages of the continental, Upper Cretaceous, Fruitland Formation and Kirtland Shale based on a projection of ammonite zones from the Lewis Shale, San Juan basin, New Mexico and Colorado, in Fassett, J.E., and Rigby, J.K., Jr., eds., The Cretaceous-Tertiary boundary in the San Juan and Raton basins, New Mexico and Colorado: Geological Society of America Special Paper 209, p. 5-16.

538. Fassett, J.E., 1987, Is it possible to identify eustatic sea-level-change events in the Upper Cretaceous rocks of the San Juan basin, New Mexico and Colorado? [abs.]: Geological Society of America Abstracts with Programs, v. 19, no. 7, p. 659 . 
539. Fassett, J.E., 1988, Geometry and depositional environment of Fruitland Formation coalbeds, San Juan basin, New Mexico and Colorado--Anatomy of a giant coal-bed methane deposit, in Fassett, J.E., ed., Geology and coal-bed methane resources of the northern San Juan basin, Colorado and New Mexico: Denver, Rocky Mountain Association of Geologists, p. 23-38.

541. Feast, C.F., 1984, Meeker Dome salinity investigation, in French, R.H., ed., Salinity in watercourses and reservoirs--International Symposium on State-of-the-Art Control of Salinity, Salt Lake City, July 13-15, 1983, Proceedings: Boston, Butterworth Publishers, p. 359-365.

542. Fellows, A.L., 1902, Water resources of the State of Colorado: U.S. Geological Survey Water-Supply Paper 74, 151 p.

543. Fenneman, N.M., and Gale, H.S., 1906, The Yampa Coal Field, Routt County, Colorado, with a chapter on the character and use of the Yampa coals, by M.R. Campbell: U.S. Geological Survey Bulletin 297, 96 p.

544. Fenneman, N.M., and Gale, H.S., 1906, The Yampa Coal Field, Routt County, Colorado: U.S. Geological Survey Bulletin 285-F, p. 226-239.

545. Fenske, J.M., Jr., 1985, A depositional model for middle Mesaverde coals, Yampa Field, northwestern Colorado: Lexington, University of Kentucky, Master's thesis, unknown pagination.

546. Ferraro, Paul, 1982, Water quality management issues of concern to the Colorado Department of Health, in Petersen, K.K., ed., Proceedings of an international symposium on oil shale--The enviornmental challenges II: Golden, Colorado School of Mines Press, p. 29-37.

547. Feth, J.H., 1964, Review and annotated bibliography of ancient lake deposits (Precambrian to Pleistocene) in the Western States: U.S. Geological Survey Bulletin 1080, 119 p.

548. Feth, J.H., 1965, Calcium, sodium, sulfate, and chloride in stream water of the western conterminous United States to 1957: U.S. Geological Survey Hydrologic Investigations. Atlas HA-189, 4 sheets, scale $1: 2,500,000$.

549. Feth, J.H., and others, 1965, Preliminary map of the conterminous United States showing depth to and quality of shallowest ground water containing more than 1,000 parts per million dissolved solids: U.S. Geological Survey Hydrologic Investigations Atlas HA-199, 2 sheets, scale $1: 3,168,000$, accompanied by 31 -page text.

550. Ficke, J.F., Weeks, J.B., and Welder, F.A., 1974, Hydrologic data from the Piceance basin, Colorado: Colorado Water Resources Basic-Data Release $31,246 \mathrm{p}$.

551. Ficklin, W.H., and Ryder, J.L., 1988, Arsenic species in ground water and pore waters in stream sediments affected by mine drainage in Montana and Colorado, in Ragone, S.E., ed., U.S. Geological Survey program on toxic waste--Ground-water contamination; proceedings of the second technical meeting, Cape Cod, Mass., Oct. 21-25, 1985: U.S. Geological Survey Open-File Report 86-481, p. E9-E11.

552. Ficklin, W.H., Smith, C.L., and Motooka, J.M., 1986, Analytical results for 38 hot spring samples collected in the Western United States: U.S. Geologica1 Survey Open-File Report 86-283, 3 p.

553. Finen, W.C., ed., 1957, Guidebook to the geology of North and Middle Parks basin, Colorado: Denver, Rocky Mountain Association of Geologists, $152 \mathrm{p}$.

554. Finlay, E.A., 1951, Geology of Dove Creek area, Dolores and Montezuma Counties, Colorado: U.S. Geological Survey 0il and Gas Investigations Map OM-120, scale 1:48,000. [Reprinted 1995.] 
555. Fischer, R.C., 1974, Colorado oil shale and water, in 7th 0il Shale Symposium Proceedings: Colorado School of Mines Quarterly, v. 69, no. 2, p. 133-139.

556. Fischer, R.P., and Hilpert, L.S., 1952, Geology of the Uravan mineral belt: U.S. Geological Survey Bulletin 988-A, p. 1-13.

558. Fischer, R.P., Luedke, R.G., Sheridan, M.J., and Raabe, R.G., 1968, Mineral resources of the Uncompahgre primitive area, Colorado: U.S. Geological Survey Bulletin 1261-C, p. C1-C91.

559. Fisher, D.J., Erdmann, C.E., and Reeside, J.B., Jr., 1960, Cretaceous and Tertiary formations of the Book Cliffs, Carbon, Emery and Grand Counties, Utah, and Garfield and Mesa Counties, Colorado: U.S. Geological Survey Professional Paper 332, 80 p.

560. Fleischer, Michael, 1962, Fluoride content of ground water in the conterminous United States: U.S. Geological Survey Miscellaneous Geologic Investigations Map I-387, scale 1:5,000,000.

561. Fleisher, C.J., Whitney, J.A., and Stormer, J.C., Jr., 1987, Stratigraphy, petrology, and geochemistry of the Fish Canyon Tuff, Mount Hope Caldera, San Juan Mountains, Colorado [abs.]: Geological Society of America Abstracts with Programs, v. 19, no. 5, p. 275.

562. Fleisher, P.J., 1975, Geology of selected national parks and monuments: Dubuque, Iowa, Kendall-Hunt Publishing Company, 183 p.

563. Florquist, B.A., 1973, Techniques for locating water wells in fractured crystalline rocks: Ground Water, v. 11 , no. 3, p. 26-28.

564. Forester, R.W., and Taylor, H.P., Jr., 1972, Oxygen and hydrogen isotope data on the interaction of meteoric ground waters with a gabbro-diorite stock, San Juan Mountains, Colorado, in Geochemistry--Geochimie, section 10: International Geological Congress Proceedings 24, p. 254-263.

567. Four Corners Geological Society, 1957, Geology of southwestern San Juan basin, 2d Four Corners fField conference, 1957 [Guidebook]: [Durango, Colo.], Four Corners Geological Society, 198 p.

568. Four Corners Geological Society, 1960, Geology of the Paradox basin fold and fault belt (Colorado Plateau), 3d Four Corners field conference, 1960, Guidebook: [Durango, Colo.], Four Corners Geological Society, $183 \mathrm{p}$.

569. Four Corners Geological Society, 1964, Durango-Silverton guidebook, American Association of Petroleum Geologists, Rocky Mountain Section, Annual Regional Convention, 14th, 1964: [Durango, Colo.], Four Corners Geological Society, 84 p.

570. Franczyk, K.J., 1989, Depositional controls on the late Campanian Sego Sandstone and implications for associated coal-forming environments in the Uinta and Piceance basins: U.S. Geological Survey Bulletin 1787-F, p. F1-F17.

571. Franczyk, K.J., and Nichols, D.J., 1986, Unconformity-bounded Paleocene conglomerate sequence, southeastern Uinta Basin [abs.]: American Association of Petroleum Geologists Bulletin, v. 70, no. 8, p. 1039-1040.

572. Frank, W.F., Beckett, S.F., Nylander, D.C., Kolkman, Beverly, Wilson, J.E., and Cox, R.A., 1986, Draft environmental impact statement--Wolf Ridge Corporation mine plan for a nahcolite solution mine: U.S. Bureau of Land Management, various pagination.

573. Freeman, R.N., 1950, Geology of the Round Mountain area of Gunnison County, Colorado, and a petrological study of the Coffman Conglomerate: Lexington, University of Kentucky, Master's thesis, $46 \mathrm{p}$. 
574. Freeman, V.F., and Bryant, Bruce, 1977, Red bed formations in the Aspen region, Colorado, in Veal, H.K., ed., Exploration frontiers of the central and southern Rockies: [Denver], Rocky Mountain Association of Geologists Field Conference [Guidebook], v. 1977, p. 181-189.

575. Freeman, V.L., 1971, Stratigraphy of the State Bridge Formation in the Woody Creek Quadrangle, Pitkin and Eagle Counties, Colorado: U.S. Geological Survey Bulletin 1324-F, 17 p.

576. Freeman, V.L., 1972, Geologic map of the Woody Creek Quadrangle, Pitkin and Eagle Counties, Colorado: U.S. Geological Survey Geologic Quadrangle Map GQ-967, scale 1:24,000.

577. Freeman, V.L., 1972, Geologic map of the Ruedi Quadrangle, Pitkin and Eagle Counties, Colorado: U.S. Geological Survey Geologic Quadrangle Map GQ-1004, scale $1: 24,000$.

578. Freeman, W.E., and Visher, G.S., 1975, Stratigraphic analysis of the Navajo Sandstone: Journal of Sedimentary Petrology, v. 45, no. 3, p. 651-668.

579. Freethey, G.W., 1969, Hydrogeologic evaluation of pollution potential in mountain dwelling sites (Colorado): Fort Collins, Colorado State University, Master's thesis, $90 \mathrm{p}$.

580. Freethey, G.W., 1987, Upper Colorado River Basin regional aquifer-systems analysis--Mesozoic rocks in Colorado, Utah, Wyoming, Arizona, and New Mexico, in McLean, J.S., and Johnson, A.I., eds., Regional aquifer systems of the United States--Aquifers of the western mountain area: American Water Resources Association Monograph Series 14, p. 57-70.

581. Freethey, G.W., 1987, Lithologic and hydrologic properties of Mesozoic rocks in the Upper Colorado River Basin, in McLean, J.S., and Johnson, A.I., eds., Regional aquifer systems of the United States--Aquifers of the western mountain area: American Water Resources Association Monograph Series 14, p. 81-99.

582. Freethey, G.W., Kimba11, B.A., Wilberg, D.E., and Hood, J.W., 1988, General hydrogeology of the aquifers of Mesozoic age, Upper Colorado River Basin; excluding the San Juan basin; Colorado, Utah, Wyoming, and Arizona: U.S. Geological Survey Hydrologic Investigations Atlas HA-698, 2 sheets, scale $1: 2,500,000$.

584. Frenzel, P.F., Craigg, S.D., and Padgett, E.T., 1981, Preliminary data report for the San Juan basin-Crownpoint surveillance study: U.S. Geological Survey Open-File Report 81-484, 36 p.

585. Frenzel, P.F., and Lyford, F.P., 1982, Estimates of vertical hydraulic conductivity and regional ground-water flow rates in rocks of Jurassic and Cretaceous age, San Juan basin, New Mexico and Colorado: U.S. Geological Survey Water-Resources Investigations Report 82-4015, 59 p.

586. Freshley, M.D., Reisenauer, A.E., and Gee, G.W., 1985, Sensitivity analysis applied to unsaturated flow modeling of a retorted oil shale pile: Soil Science Society of America Journal, v. 49, no. 1, p. 28-34.

587. Friedman, J.D., and Simpson, S.L., 1978, Landsat investigations of the northern Paradox basin, Utah and Colorado--Implications for radioactive waste emplacement: U.S. Geological Survey Open-File Report 78-900, 60 p.

588. Friedman, J.D., and Simpson, S.L., 1980, Lineaments and geologic structure of the northern Paradox basin, Colorado and Utah: U.S. Geological Survey Miscellaneous Field Studies Map MF-1221, 2 sheets, scales $1: 250,000$ and $1: 500,000$.

589. Fryberger, S.G., 1978, Stratigraphy of the Weber Formation (Pennsylvanian-Permian), Dinosaur National Monument and adjacent area, Utah and Colorado: Golden, Colorado School of Mines, Master's thesis, 105 p. 
590. Fuller, M.L., Clapp, F.G., and Johnson, B.L., 1906, Bibliographic review and index of underground-water literature published in the United States in 1905: U.S. Geological Survey Water-Supply Paper 163, $130 \mathrm{p}$.

591. Gabelman, J.W., 1949, Geology and ore deposits of the Fulford mining district, Eagle County, Colorado: Golden, Colorado School of Mines, $\mathrm{Ph} . \mathrm{D}$. dissertation, $188 \mathrm{p}$.

592. Gabelman, J.W., 1950, Geology of the Fulford and Brush Creek mining districts, Eagle County, Colorado: [Denver?], Colorado Mining Association, Mining Year Book, p. 50-52.

593. Gabelman, J.W., 1955, Cylindrical structures in Permian (?) siltstone, Eagle County, Colorado: Journal of Geology, v. 63, no. 3, p. 214-227.

594. Gaffke, T.M., 1979, Depositional environments of a coal-bearing system in the Upper Cretaceous Mesaverde Group, Routt County, Colorado: U.S. Geological Survey Open-File Report 79-1669, 16 p.

595. Gaggiani, N.G., 1989, Indexes of hydrologic data from selected coalmining areas in northwestern Colorado: U.S. Geological Survey Open-File Report 88-347, $30 \mathrm{p}$.

596. Gaggiani, N.G., 1989, Northern Great Plains and Rocky Mountain provinces--Green River and Hams Fork regions, in Britton, L.J., Anderson, C.L., Goolsby, D.A., and Van Haveren, B.P., eds., Summary of the U.S. Geological Survey and U.S. Bureau of Land Management national coalhydrology program, 1974-84: U.S. Geological Survey Professional Paper 1464, p. 85-94.

597. Gale, H.S., 1908, Geology of the Rangely oil district, Rio Blanco County, Colorado, with a section on The water supply: U.S. Geological Survey Bulletin 350, 61 p.

598. Galloway, M.J., and Atkinson, W.W., Jr., 1980, Hydrogeologic and geothermal investigation of Pagosa Hot Springs, Colorado: Colorado Geological Survey Special Publication 10, 96 p., 3 plates.

599. Galloway, W.E., 1979, Morrison Formation of the Colorado Plateau, in Galloway, W.E., ed., Depositional and ground-water flow systems in the exploration for uranium: Austin, Univeristy of Texas, Bureau of Economic Geology, p. 214-228.

600. Galyean, K.C., Jenkins, R.A., and Collins, D.L., 1985, Hydrologic data from Naval 0il Shale Reserves, Parachute Creek basin, northwestern Colorado, water years 1982-83: U.S. Geological Survey Open-File Report 85-647, $91 \mathrm{p}$.

601. Gannon, J.E., 1957, Drilling in the Coal Creek area, Rio Blanco County, Colorado: U.S. Atomic Energy Commission Report TM-151, 5 p.

602. Gardner, R.L., and Young, R.A., 1988, Assessing strategies for control of irrigation-induced salinity in the Upper Colorado River Basin: American Journal of Agricultural Economics, v. 70, no. 1, p. 37-49.

603. Garland, T.R., Wildung, R.E., and Zachara, J.M., 1988, Case study of the effects of oil shale operations on surface- and ground-water quality--I, Sources of contamination and hydrologic controls on water composition: Journal of Environmental Quality JEVQAA, v. 17, no. 4, p. 653-659.

604. Garland, T.R., Zachara, J.M., and Wildung, R.E., 1988, Case study of the effects of oil shale operations on surface- and ground-water quality--II, Major inorganic ions: Journal of Environmental Quality JEVQAA, v. 17, no. 4, p. 660-666.

605. Garrett, H.L., 1950, The geology of the Star basin and Star mine, Gunnison County, Colorado: Golden, Colorado School of Mines, Master's thesis, $45 \mathrm{p}$. 
606. Garrigues, R.S., 1976, Geophysical logs of holes drilled in 1976 in the Lower White River Coal Field, Moffat and Rio Blanco Counties, Colorado: U.S. Geological Survey Open-File Report 76-871, 11 p.

607. Garrigues, R.S., and Barnum, B.E., 1980, Geologic map and coal sections of the Rangely NE Quadrangle, Rio Blanco and Moffat Counties, Colorado: U.S. Geological Survey Open-File Report 80-274, 2 sheets, scale 1:24,000.

608. Gaskill, D.L., 1961, Age of the Ohio Creek Conglomerate, Gunnison County, Colorado, in Short papers in the geologic and hydrologic sciences, 1961: U.S. Geological Survey Professional Paper 424-B, p. B230-B231.

609. Gaskil1, D.L., Colman, S.M., DeLong, J.E., Jr., and Robinson, C.H., 1986, Geologic map of the Crested Butte Quadrangle, Gunnison County, Colorado: U.S. Geological Survey Geologic Quadrangle Map GQ-1580, scale 1:24,000.

610. Gaski11, D.L., Delong, J.E., Jr., and Cochran, D.M., 1987, Geologic map of the Mt. Axtell Quadrangle, Gunnison County, Colorado: U.S. Geological Survey Geologic Quadrangle Map GQ-1604, 7 p., scale 1:24,000.

611. Gaskill, D.L., and Godwin, L.H., 1966, Geologic map of the Marble Quadrangle, Gunnison and Pitkin Counties, Colorado: U.S. Geological Survey Geologic Quadrangle Map GQ-512, scale 1:24,000.

612. Gaskill, D.L., and Godwin, L.H., 1966, Geologic map of the Marcellina Mountain Quadrangle, Gunnison County, Colorado: U.S. Geological Survey Geologic Quadrangle Map GQ-511, scale 1:24,000.

613. Gaski11, D.L., Godwin, L.H., and Mutschler, F.E., 1967, Geologic map of the Oh-Be-Joyful Quadrangle, Gunnison County, Colorado: U.S. Geological Survey Geologic Quadrangle Map GQ-578, scale 1:24,000.

614. Gates, 01cott, 1950, Geology of the west side of the Gore Range near Radium (Grand and Eagle Counties), Colorado: Boulder, University of Colorado, Master's thesis, $69 \mathrm{p}$.

615. Gatewood, J.S., Wilson, A., Thomas, H.E., and Kister, L.R., 1964, General effects of drought on water resources of the Southwest: U.S. Geological Survey Professional Paper 372-B. p. B1-B55.

616. Gazin, C.L., 1959, Paleontological exploration and dating of the early Tertiary deposits in basins adjacent to the Uinta Mountains--Utah, Wyoming, Colorado, in Intermountain Association of Petroleum Geologists, 10th annual field conference, 1959 [Guidebook]: [Salt Lake City], Intermountain Association of Petroleum Geologists, p. 131-138.

617. Geldon, A.L., 1985, Water resources of the Cottonwood Wash watershed, Ute Mountain, Ute Indian Reservation, southwestern Colorado: U.S. Geological Survey Water-Resources Investigations Report 85-4027, 56 p.

618. Geldon, A.L., 1986, Hydrostratigraphic characterization of Paleozoic formations in northwestern Colorado, in Stone, D.S., and Johnson, K.S., eds., New interpretations of northwest Colorado geology: Denver, Rocky Mountain Association of Geologists Guidebook, p. 265-281.

619. Geldon, A.L., 1987, Hydrostratigraphic characterization of paleozoic formations in the Upper Colorado River Basin, Arizona, Colorado, New Mexico, Utah, and Wyoming, in McLean, J.S., and Johnson, A.I., eds., Regional aquifer systems of the United States--Aquifers of the western mountain area: American Water Resources Association Monograph Series 14, p. $135-159$.

620. Geldon, A.L., 1987, Porosity and permeability of the Paleozoic rocks in the Upper Colorado River Basin, Arizona, Colorado, New Mexico, Utah, and Wyoming, in McLean, J.S., and Johnson, A.I., eds., Regional aquifer systems of the United States--Aquifers of the western mountain area: American Water Resources Association Monograph Series 14, p. 171-190. 
621. Geldon, A.L., 1989, Hydrogeology of the Leadville Limestone and other Paleozoic rocks in northwestern Colorado, with results of aquifer tests at Glenwood Springs: U.S. Geological Survey Water-Resources Investigations Report 87-4195, 96 p.

622. Geldon, A.L., 1989, Hydrologic data for Paleozoic rocks in the Upper Colorado River Basin, Colorado, Utah, Wyoming, and Arizona: U.S. Geological Survey Open-File Report 89-59, 219 p.

623. George, R.D., and Crawford, R.D., 1908, The Hahns Peak region, Routt County, Colorado: Colorado Geological Survey First Report, p. 189-229.

624. George, R.D., Curtis, H.A., Lester, O.C., and others, 1920, Mineral waters of Colorado: Colorado Geological Survey Bulletin 11, $474 \mathrm{p}$.

625. Gesink, M.L., 1983, Preliminary hydrogeologic investigations of the White River alluvial aquifer, Rio Blanco County, Colorado: Golden, Colorado School of Mines, Master's thesis, 212 p.

626. Ghellali, S.M., 1970, Geology of the vicinity of the Villa Grove Mine, Saguache County, Colorado: Columbia, University of Missouri, Master's thesis, unknown pagination.

627. Gibbs, James, Healy, J.H., Raleigh, C.B., and others, 1973, Seismicity in the Rangely, Colorado, area, 1962-1970: Seismological Society of America Bulletin, v. 63, no. 5, p. 1557-1570.

628. Gibson, J.G., 1953, General geology of the Farris Creek area, Gunnison County, Colorado, and Gothic-Maroon (Pennsylvanian and Permian) stratigraphy: Lexington, University of Kentucky, Master's thesis, $45 \mathrm{p}$.

629. Gibson, Russe11, 1922, Structural geology and ore deposits of the Red Cliff Mining Region (Eagle County), Colorado: Boulder, University of Colorado, Master's thesis, 28 p.

630. Giles, T.F., 1980, Reconnaissance of ground-water resources in the vicinity of Gunnison and Crested Butte, west-central Colorado: U.S. Geological Survey Water-Resources Investigations Open-File Report 80-12, 2 sheets, scale not listed.

631. Giles, T.F., and Brogden, R.E., 1976, Water-quality data for the Eagle River valley in the vicinity of Eagle and Vail, west-central Colorado: U.S. Geological Survey Open-File Report 76-812, 2 sheets, scale $1: 125,000$.

632. Giles, T.F., and Brogden, R.E., 1978, Selected hydrologic data, Yampa River basin and parts of the White River basin, northwestern Colorado and south-central Wyoming: U.S. Geological Survey Open-File Report 78-23, $106 \mathrm{p}$.

633. Gi11, J.R., and Freeman, V.L., 1978, Stratigraphic sections of the upper Mancos Shale-lower Mesaverde Formation interval along the Grand Hogback between Rifle Gap and North Thompson Creek, Garfield and Pitkin Counties, Colorado: U.S. Geological Survey Open-File Report 78-178, scale not listed.

634. Gill, J.R., and Hail, W.J., Jr., 1975, Stratigraphic sections across Upper Cretaceous Mancos Shale--Mesaverde Group boundary, eastern Utah and western Colorado: U.S. Geological Survey Oil and Gas Investigations Chart 0C-68, scale not listed.

635. Gillam, M.L., Moore, D.W., and Scott, G.R., 1984, Quaternary deposits and soils in the Durango area, southwestern Colorado, in Brew, D.C., ed., Paleotectonics; San Juan Mountains of America, Rocky Mountain Section, 37th annual meeting, Durango, Colo., 1984: Durango, Colo., Four Corners Geological Society, Geological Society of America Field Trip Guidebook 1, 3-5, p. 149. 
636. Girdley, W.A., 1968, Pennsylvanian coralline limestone, San Juan Mountains, Colorado: Compass, v. 46, no. 1 , p. 38-45.

637. Goddard, E.N., 1936, The geology and ore deposits of the Tincup mining district, Gunnison County: [Denver?], Colorado Scientific Society Proceedings, v. 13, no. 10, p. 551-595.

638. Godwin, L.H., 1968, Geologic map of the Chair Mountain Quadrangle, Gunnison and Pitkin Counties, Colorado: U.S. Geological Survey Geologic Quadrangle Map GQ-704, scale 1:24,000.

639. Godwin, L.H., and Gaskill, D.L., 1964, Post-Paleocene West Elk laccolithic cluster, west-central Colorado in Geological Survey research 1964: U.S. Geological Survey Professional Paper 501-C, p. C66-C68.

640. Gonzales, D.A., 1988, A geologic investigation of the early Proterozoic Irving Formation, southeastern Needle Mountains, Colorado: U.S. Geological Survey Open-File Report 88-660, 119 p., 4 sheets.

641. Goodknight, C.S., and Ludlam, J.R., 1981, Montrose Quadrangle, Colorado: U.S. Department of Energy, National Uranium Resource Evaluation Program Report GJQ-010(81), $91 \mathrm{p}$.

643. Gorton, K.A., 1953, Geology of the Cameron Pass area, Grand, Jackson and Larimer Counties, Colorado, in Laramie basin, Wyoming, and North Park, Colorado: Casper, Wyoming Geological Association Guidebook 8, p. 87-98.

644. Gould, D.B., and Jackson, V.N., 1957, Airphoto stratigraphy of North and Middle Parks [Colorado], in Finch, W.C., ed., Guidebook to the geology of North and Middle Parks Basin, Colorado: Denver, Rocky Mountain Association of Geologists, p. 42-47.

645. Grabowski, G.J., Jr., and Pevear, D.R., 1986, Mechanical deformation controlled by amount of organic matter, Green River Formation, Colorado [abs.?]: American Association of Petroleum Geologists Bulletin, v. 70, no. 5, p. 596.

646. Grace, W.P., and Nelson, G.A., 1962, Danforth Hills area, townships 2 to 5 north, ranges 93 to 96 west, Moffat and Rio Blanco Counties, Colorado, in Mott, M.R., and Amuedo, C.L., eds., Exploration for oil and gas in northwestern Colorado: Denver, Rocky Mountain Association of Geologists Guidebook, p. 92-95.

647. Graff, P., 1973, The areal geology of the West Fork Lake Quadrangle, northern Colorado: De Kalb, Northern Illinois University, Master's thesis, unknown pagination.

648. Grand Junction Geological Society, 1982, Southeastern Piceance basin, western Colorado: [Grand Junction, Colo.?] Grand Junction Geological Society field trip, Sept. 25-26, 1982, [Guidebook?], 97 p.

649. Granica, M.P., and Johnson, R.C., 1980, Structure contour map and isochore map of the nonmarine part of the Mesaverde Group, Piceance Creek basin, Colorado: U.S. Geological Survey Miscellaneous Field Studies Map MF-1189, scale $1: 250,000$.

650. Gras, V.B., 1955, Vermilion Creek basin area, Sweetwater County, Wyoming, and Moffat County, Colorado, in Green River basin: [Laramie?], Wyoming Geological Association, 10th annual field conference, 1955, Guidebook, p. 177-181.

651. Gras, V.B., 1955, Vermilion Creek basin area, Sweetwater County, Wyoming, and Moffat County, Colorado, in Ritzma, H.R., and Oriel, S.S., eds., Guidebook to the geology of northwest Colorado, Intermountain Association of Petroleum Geologists, 6th annual field conference, and Rocky Mountain Association of Geologists annual field conference, 1955: Salt Lake City, Intermountain Association of Petroleum Geologists, p. 78-83. 
652. Graves, Timothy, 1984, Predicting the performance of water wells in crystalline rocks, Front Range, Colorado: Fort Collins, Colorado State University, Master's thesis, $66 \mathrm{p}$.

653. Green, M.W., and Pierson, C.T., 1977, A summary of the stratigraphy and depositional environments of Jurassic and related rocks in the San Juan Basin, Arizona, Colorado and New Mexico, in Fassett, J.E.., ed., Guidebook of San Juan Basin III, northwestern New Mexico: [Socorro?], New Mexico Geological Society, 28th field conference, 1977, p. 147-152.

654. Gregg, D.0., Meyer, E.L., Torgy, M.M., and Moulder, E.A., 1961, Ground water, in Public water supplies of Colorado, 1959-60: Fort Collins, Colorado State University Agricultural Experiment Station General Series 757, p. 16-21.

655. Grout, F.F., Worcester, P.G., and Henderson, J., 1913, Reconnaissance of the geology of the Rabbit Ears region, Routt, Grand and Jackson Counties: Colorado Geological Survey Bulletin, no. 5, pt. 1, 57 p.

656. Grove, D.B., Miller, R.L., Konikow, L.F., and 0'Boyle, P.S., 1979, Hexavalent chromium in the ground and surface waters near Telluride, Colorado--Preliminary data report: U.S. Geological Survey Open-File Report 79-700, 18 p. [Available from U.S. Geological Survey, Water Resources Division, Box 25046, Mail Stop 415, Denver Federal Center, Denver, CO 80225-0046.]

657. Gualtieri, J.L., 1979, Preliminary results of coal exploratory drilling in the Book Cliffs coal region, Garfield County, Colorado, and Grand County, Utah: U.S. Geological Survey Open-File Report 79-999, 57 p.

658. Gualtieri, J.L., 1980, Geologic strip map of parts of the Bar X Wash, Bryson Canyon, Jim Canyon and San Arroyo Ridge Quadrangles, Utah and Colorado, showing coal zones and adjacent racks: U.S. Geological Survey Open-File Report 80-1228, scale 1:50,000.

659. Gualtieri, J.L., 1988, Geologic map of the Westwater 30- by 60-Minute Quadrangle, Grand and Uintah Counties, Utah and Garfield and Mesa Counties, Colorado: U.S. Geological Survey Miscellaneous Investigations Series Map I-1765, scale 1:100,000.

661. Hackett, 0.M., 1963, Ground-water levels in the United States, 19561960--Northwestern States: U.S. Geological Survey Water-Supply Paper $1760,220 \mathrm{p}$.

662. Hackman, R.J., 1955, Photogeologic map of the Aneth-1 Quadrangle, San Juan County, Utah, and Montezuma County, Colorado: U.S. Geological Survey Miscellaneous Geologic Investigations Map I-90, scale 1:24,000.

663. Hackman, R.J., 1955, Photogeologic map of the Aneth-8 Quadrangle, San Juan County, Utah, and Montezuma County, Colorado: U.S. Geological Survey Miscellaneous Geologic Investigations Map I-97, scale 1:24,000.

664. Hackman, R.J., 1956, Photogeologic map of the Mount Peale-1 Quadrangle, San Juan County, Utah, and Montrose County, Colorado: U.S. Geological Survey Miscellaneous Geologic Investigations Map I-165, scale 1:24,000.

665. Hackman, R.J., 1956, Photogeologic map of the Mount Peale-9 Quadrangle, San Juan County, Utah, and Montrose and San Miguel Counties, Colorado: U.S. Geological Survey Miscellaneous Geologic Investigations Map I-157, scale $1: 24,000$.

666. Hackman, R.J., 1956, Photogeologic map of the Mount Peale-8 Quadrangle, San Juan County, Utah, and Montrose County, Colorado: U.S. Geological Survey Miscellaneous Geologic Investigations Map I-174, scale 1:24,000.

667. Hackman, R.J., 1956, Photogeologic map of the Mount Peale-16 Quadrangle, San Juan County, Utah, and San Miguel County, Colorado: U.S. Geological Survey Miscellaneous Geologic Investigations Map I-176, scale 1:24,000. 
668. Hackman, R.J., 1958, Photogeologic map of the Escalante Forks Quadrangle, Mesa, Montrose, and Delta Counties, Colorado: U.S. Geological Survey Miscellaneous Geologic Investigations Map I-274, scale 1:62,500.

669. Hackman, R.J., 1959, Photogeologic map of the Yellow Jacket Quadrangle, Montezuma and Dolores Counties, Colorado: U.S. Geological Survey Miscellaneous Geologic Investigations Map I-281, scale 1:62,500.

670. Hackman, R.J., 1959, Photogeologic map of the Coach Creek NE Quadrangle, Grand County, Utah, and Mesa County, Colorado: U.S. Geological Survey Miscellaneous Geologic Investigations Map I-279, scale 1:24,000.

671. Hackman, R.J., 1959, Photogeologic map of the Coach Creek SE Quadrangle, Grand County, Utah, and Mesa County, Colorado: U.S. Geological Survey Miscellaneous Geologic Investigations Map I-278, scale 1:24,000.

672. Hadley, D.W., 1953, Correlation and distribution of Pleistocene gravel deposits in the La Plata and Animas River valleys, La Plata County, Colorado: Urbana, University of Illinois, Bachelor's thesis, $21 \mathrm{p}$.

674. Hail, W.J., Jr., 1968, Geology of southwestern North Park and vicinity, Colorado: U.S. Geological Survey Bulletin 1257, 119 p.

675. Hail, W.J., Jr., 1972, Reconnaissance geologic map of the Cedaredge area, Delta County, Colorado: U.S. Geological Survey Miscellaneous Investigations Series Map I-697, scale 1:48,000.

676. Hail, W.J., Jr., 1972, Reconnaissance geologic map of the Hotchkiss area, Delta and Montrose Counties, Colorado: U.S. Geological Survey Miscellaneous Investigations Series Map I-698, scale 1:48,000.

677. Hail, W.J., Jr., 1972, Preliminary geologic map of the Barcus Creek SE Quadrangle, Rio Blanco County, Colorado: U.S. Geological Survey Miscellaneous Field Studies Map MF-347, 2 sheets, scale 1:24,000.

678. Hail, W.J., Jr., 1973, Geologic map of the Smizer Gulch Quadrangle, Rio Blanco and Moffat Counties, Colorado: U.S. Geological Survey Geologic Quadrangle Map GQ-1131, scale 1:24,000.

679. Hail, W.J., Jr., 1974, Geologic map of the Rough Gulch Quadrangle, Rio Blanco and Moffat Counties, Colorado: U.S. Geological Survey Geologic Quadrangle Map GQ-1195, scale 1:24,000.

680. Hail, W.J., Jr., 1974, Preliminary geologic map and section of the Barcus Creek Quadrangle, Rio Blanco County, Colorado: U.S. Geological Survey Miscellaneous Field Studies Map MF-619, scale 1:24,000. (Reprinted)

681. Hail, W.J., Jr., 1975, Preliminary geologic map of the Cutoff Gulch Quadrangle, Rio Blanco and Garfield Counties, Colorado: U.S. Geological Survey Miscellaneous Field Studies Map MF-691, 2 sheets, scale 1:24,000.

682. Hail, W.J., Jr., 1976, Geologic reconnaissance map of the Log Hill Mesa area, Ouray, Montrose, and San Miguel Counties, Colorado: U.S. Geological Survey Open-File Report 76-68, scale 1:62,500.

683. Hail, W.J., Jr., 1977, Stewart Gulch Tongue--A new tongue of the Eocene Green River Formation, Piceance Creek basin, Colorado: U.S. Geological Survey Bulletin 1422-E, 8 p.

684. Hail, W.J., Jr., 1977, Preliminary geologic map of the Bull Fork Quadrangle, Garfield and Rio Blanco Counties, Colorado: U.S. Geological Survey Miscellaneous Field Studies Map MF-830, scale 1:24,000.

685. Hail, W.J., Jr., 1978, Preliminary geologic map of the Mount Blaine Quadrangle, Garfield County, Colorado: U.S. Geological Survey Miscellaneous Field Studies Map MF-984, scale 1:24,000.

686. Hail, W.J., Jr., 1982, Preliminary geologic map of the Circle Dot Gulch Quadrangle, Garfield County, Colorado: U.S. Geological Survey Miscellaneous Field Studies Map MF-1293, scale 1:24,000. 
687. Hail, W.J., Jr., 1984, Geologic map of the Barcus Creek Quadrangle, Rio Blanco County, Colorado: U.S. Geological Survey Geologic Quadrangle Map GQ-1578, scale $1: 24,000$.

688. Hail, W.J., Jr., 1987, Reconnaissance geologic map of the Colona Quadrangle, Montrose and Ouray Counties, Colorado: U.S. Geological Survey Miscellaneous Field Studies Map MF-2003, scale 1:24,000.

689. Hail, W.J., Jr., 1987, Chart showing intertongued units of the Eocene Green River and Uinta Formations, northwestern Piceance Creek basin, northwestern Colorado: U.S. Geological Survey Miscellaneous Investigations Series Map I-1797-B, no scale listed.

690. Hail, W.J., Jr., 1988, Geologic map of the Barcus Creek SE Quadrangle, Rio Blanco County, Colorado: U.S. Geological Survey Geologic Quadrangle Map GQ-1613, scale $1: 24,000$.

691. Hail, W.J., Jr., 1988, Reconnaissance geologic map of the Horsefly Peak Quadrangle, Ouray, Montrose, and San Miguel Counties, Colorado: U.S. Geological Survey Miscellaneous Field Studies Map MF-2059, scale $1: 24,000$.

692. Hail, W.J., Jr., 1989, Reconnaissance geologic map of the Ridgway Quadrangle, Ouray County, Colorado: U.S. Geological Survey Miscellaneous Field Studies Map MF-2100, scale 1:24,000.

693. Hail, W.J., Jr., and Duncan, D.C., 1984, Revised preliminary geologic map of the northern half of the Square S Ranch Quadrangle, Rio Blanco County, Colorado:- U.S. Geological Survey Open-File|Report 84-202, 6 p., scale $1: 24,000$.

694. Hail, W.J., Jr., O'Sullivan, R.B., and Smith, M.C., 1989, Geologic map of the Roan Plateau area, northwestern Colorado: U.S. Geological Survey Miscellaneous Investigations Series Map I-1797-C, scale 1:50,000.

695. Hale, L.A., and VandeGraaff, Fred, 1965, Correlations of Cretaceous formations in adjoining areas of Wyoming, Utah, and Colorado, in Sedimentation of Late Cretaceous and Tertiary outcrops, Rock Springs uplift, 19th field conference, 1965, Guidebook: Casper, Wyoming Geological Association, Petroleum Information, p. 8-9.

696. Hall, E.A., 1922, Stratigraphy of the Redcliff district (Eagle County), Colorado--The Groundhog Mine: Boulder, University of Colorado, Master's thesis, $68 \mathrm{p}$.

697. Hall, Gary, and Bullock, Jim, 1970, Third day's road log--Breckenridge to Granby, in Dakota and related rocks of the Front Range: Mountain Geologist, v. 7, no. 3, p. 244-250.

698. Hamilton, Warren, and Pakiser, L.C., 1965, Geologic and crustal cross section of the United States along the 37th paralle1--A contribution to the upper mantle project: U.S. Geological Survey Miscellaneous Geologic Investigations Map I-448, scale $1: 2,500,000$.

699. Hampton, E.R., 1974, Preliminary evaluation of ground water in the pre-Pennsylvanian carbonate rocks, McCoy area, Colorado: U.S. Geological Survey Open-File Report, 11 p.

700. Hampton, N.F., 1976, Monitoring groundwater quality--Data management: U.S. Envinronmental Protection Agency, Environmental Monitoring Series Report EPA-600/4-76-019, 62 p. [Available from National Technical Information Service, Springfield, VA 22161 as PB-255 492.]

701. Hancock, E.T., 1925, Geology and coal resources of the Axial and Monument Butte Quadrangles, Moffat County, Colorado: U.S. Geological Survey Bulletin $757,134 \mathrm{p}$. 
702. Hancock, E.T., and Eby, J.B., 1930, Geology and coal resources of the Meeker Quadrangle, Moffat and Rio Blanco Counties, Colorado, in chap. C of Contributions to economic geology, 1929--Part 2, Mineral fuels: U.S. Geological Survey Bulletin 812, p. 191-242.

703. Hanks, T.L., 1962, Geology and coal deposits, Ragged-Chair Mountain area, Pitkin and Gunnison Counties, Colorado: Provo, Utah, Brigham Young University, Geology Studies, v. 9, pt. 2, p. 137-160.

704. Hansen, W.R., 1961, Geology of the Willow Creek Butte Quadrangle, UtahColorado: U.S. Geological Survey Miscellaneous Geologic Investigations Map I-322, scale 1:24,000.

705. Hansen, W.R., 1965, The Black Canyon of the Gunnison--Today and yesterday: U.S. Geological Survey Bulletin 1191, 76 p.

706. Hansen, W.R., 1965, Geology of the Flaming Gorge area, Utah-ColoradoWyoming: U.S. Geological Survey Professional Paper 490, 196 p.

707. Hansen, W.R., 1967, The lower Black Canyon of the Gunnison: National Parks Magazine, v. 41, no. 238, p. 14-19.

708. Hansen, W.R., 1968, Geologic map of the Black Ridge Quadrangle, Delta and Montrose Counties, Colorado: U.S. Geological Survey Geologic Quadrangle Map GQ-747, scale 1:24,000.

709. Hansen, W.R., 1969, The geologic story of the Uinta Mountains: U.S. Geological Survey Bulletin 1291, $144 \mathrm{p}$.

710. Hansen, W.R., 1971, Geologic map of the Black Canyon of the Gunnison River and vicinity, western Colorado: U.S. Geological Survey Miscellaneous Investigations Series Map I-584, 2 sheets, scale 1:31,680.

711. Hansen, W.R., 1977, Geologic map of the Canyon of Lodore South Quadrangle, Moffat County, Colorado: U.S. Geological Survey Geologic Quadrangle Map GQ-1403, scale 1:24,000.

712. Hansen, W.R., 1977, Geologic map of the Jones Hole Quadrangle, Uintah County, Utah, and Moffat County, Colorado: U.S. Geological Survey Geologic Quadrangle Map GQ-1401, scale 1:24,000.

713. Hansen, W.R., 1977, Geologic map of the Zenobia Peak Quadrangle, Moffat County, Colorado: U.S. Geological Survey Geologic Quadrangle Map GQ-1408, scale $1: 24,000$.

714. Hansen, W.R., 1981, Geologic and physiographic highlights of the Black Canyon of the Gunnison River and vicinity, Colorado, in Epis, R.C., and Callender, J.F., eds., Western Slope, Colorado--Western Colorado and eastern Utah: [Socorro?], New Mexico Geological Society Guidebook 32, p. $145-154$.

715. Hansen, W.R., and Carrara, P.E., 1980, Geologic map of the Tanks Peak Quadrangle, Moffat County, Colorado: U.S. Geological Survey Geologic Quadrangle Map GQ-1534, scale 1:24,000.

716. Hansen, W.R., Carrara, P.E., and Rowley, P.D., 1980, Geologic map of the Haystack Rock Quadrangle, Moffat County, Colorado: U.S. Geological Survey Geologic Quadrangle Map GQ-1535, 1:24,000.

717. Hansen, W.R., Carrara, P.E., and Rowley, P.R., 1982, Geologic map of the Canyon of Lodore North Quadrangle, Moffat County, Colorado: U.S. Geological Survey Geologic Quadrangle Map GQ-1568, scale 1:24,000.

718. Hansen, W.R., and Rowley, P.D., 1980, Geologic map of the Stuntz Reservoir Quadrangle, Utah-Colorado: U.S. Geological Survey Geologic Quadrangle Map GQ-1530, scale 1:24,000.

719. Hansen, W.R., and Rowley, P.D., 1980, Geologic map of the Hells Canyon Quadrangle, Moffat County, Colorado: U.S. Geological Survey Geologic Quadrangle Map GQ-1536, scale 1:24,000. 
720. Hansen, W.R., Rowley, P.D., and Carrara, P.E., 1983, Geologic map of Dinosaur National Monument and vicinity, Utah and Colorado: U.S. Geological Survey Miscellaneous Investigations Series Map I-1407, scale $1: 50,000$.

721. Hanshaw, B.B., 1958, Structural geology of the west side of the Gore Range, Eagle County, Colorado: Boulder, University of Colorado, Master's thesis, $51 \mathrm{p}$.

722. Hanshaw, B.B., and Hill, G.A., 1969, Geochemistry and hydrodynamics of the Paradox basin region, Utah, Colorado and New Mexico, in Geochemistry of subsurface brines: Chemical Geology, v. 4, no. 1-2, p. 263-294.

723. Hansley, P.L., 1981, Mineralogy, diagenesis, and provenance of Upper Cretaceous sandstones from the Ralston Production Company Federal No. 31 well, Piceance Creek basin, northwestern Colorado: U.S. Geological Survey Open-File Report 81-1295, 23 p.

724. Hansley, P.L., and Johnson, R.C., 1979, Preliminary results of mineralogic and diagenetic studies of low-permeability sandstones of Late Cretaceous age, Piceance Creek basin, northwestern Colorado: U.S. Geological Survey Open-File Report 79-1702, 42 p.

725. Hansley, P.L., and Johnson, R.C., 1980, Mineralogy and diagenesis of low-permeability sandstones of Late Cretaceous age, Piceance Creek basin, northwestern Colorado: Mountain Geologist, v. 17, no. 4, p. 88-106.

726. Harris, C.W., 1988, A sedimentological and structural analys is of the Proterozoic Uncompahgre Group, Needle Mountains, Colorado: Blacksburg, Virginia Polytechnic Institute, Ph.D. dissertation, 261 p.

727. Hart, F.C., 1931, Water table "sump" area: [Denver], Colorado Division of Water Resources Special Investigations, $48 \mathrm{p}$.

728. Hart, S.S., comp., 1976, Geology for planning in the Redlands area, Mesa County, Colorado: Colorado Geological Survey Map Series 5, scale $1: 24,000$.

729. Hartner, J.D., 1981, Depositional environments of the Salt Wash Sandstones (Upper Jurassic) in portions of Rio Blanco and Moffat Counties, Colorado: Golden, Colorado School of Mines, Master's thesis, $110 \mathrm{p}$.

730. Hauck, R.A., 1954, Stratigraphy and paleontology of Devonian rocks in part of west-central Colorado--Pitkin, Eagle, and Garfield Counties: Boulder, University of Colorado, Master's thesis, 67 p.

731. Haun, J.D., 1962, Introduction to the geology of northwest Colorado, in Mott, M.R., and Amuedo, C.L., eds., Exploration for oil and gas in northwestern Colorado: Denver, Rocky Mountain Association of Geologists Guidebook, p. 7-14.

732. Haverfield, J.J., 1970, Lower Cretaceous sediment of North Park basin, in Dakota and related rocks of the Front Range: Mountain Geologist, v. 7, no. 3, p. 139-149.

733. Hawn, F., 1874, Geologic observations (in the Ute country)--Report of the reconnaissance in the Ute country, made in 1873, by [E.H.?] Ruffner: Washington, D.C., U.S. Congress, 43d, 1st Session, House Executive Document 193, p. 59-66, 69-88.

734. Hawn, Laurens, 1874, Geological notes made on the Ute reconnaissance during examination of the Animas--Report of the reconnaissance in the Ute country, made in 1873, by [E.H.?] Ruffner: Washington, D.C., U.S. Congress, 43nd, 1st Session, House Executive Document 193, p. 66-69.

735. Haworth, R.A., 1979, Stratigraphy of the Cedar Mountain and Dakota Formations (Cretaceous), Garfield County, Colorado: Golden, Colorado School of Mines, Master's thesis, $93 \mathrm{p}$. 
736. Hayden, F.V., 1877, Ninth annual report of the United States Geological and Geographical Survey of the Territories, embracing Colorado and parts of adjacent territories, being a report of progress of the exploration for the year 1875: U.S. Geological and Geographical Survey of the Territories (Hayden) Annual Report 9, 827 p.

739. Haynes, D.D., Vogel, J.D., and Wyant, D.G., comps., 1972, Geology, structure, and uranium deposits of the Cortez Quadrangle, Colorado and Utah: U.S. Geological Survey Miscellaneous Investigations Series Map I-629, 2 sheets, scale 1:250,000. (Reprinted in 1977.)

740. Headden, W.P., 1905, The Doughty Springs, a group of radium-bearing springs, Delta County, Colorado: [Denver?], Colorado Scientific Society Proceedings, v. 8, p. 1-30.

741. Headden, W.P., 1909, Notes on some mineral springs: [Denver?], Colorado Scientific Society Proceedings, v. 9, p. 259-272.

742. Hearne, G.A., Lindner-Lunsford, Jaye, Cain, Doug, Watts, K.R., Robson, S.G., Tobin, R.L., Teller, R.W., Schneider, P.A., Jr., and Gearhart, M.J., 1987, Colorado ground-water quality: U.S. Geological Survey Open-File Report 87-716, 10 p.

743. Hearne, G.A., Lindner-Lunsford, Jaye, Cain, Doug, Watts, K.R., Robson, S.G., Tobin, R.L., Teller, R.W., Schneider, P.A., Jr., and Gearhart, M.J., 1988, Colorado ground-water quality, in Moody, D.W., Carr, Jerry, Chase, E.B., and Paulson, R.W., comps., National water summary 1986-Hydrologic events and ground-water quality: U.S. Geological Survey Water-Supply Paper 2325, p. 181-190.

744. Hedge, C.E., Houston, R.S., Tweto, Ogden, Peterman, Z.E., Harrison, J.E., and Reid, R.R., 1986, The Precambrian of the Rocky Mountain region, in Harrison, J.E., and Peterman, Z.E., eds., Correlation of Precambrian rocks of the United States and Mexico: U.S. Geological Survey Professional Paper 1241-D, p. D1-D17.

745. Hedlund, D.C., 1974, Geologic map of the Big Mesa Quadrangle, Gunnison County, Colorado: U.S. Geological Survey Geologic Quadrangle Map GQ-1153, scale 1:24,000.

746. Hedlund, D.C., and Olson, J.C., 1973, Geologic map of the Carpenter Ridge Quadrangle, Gunnison County, Colorado: U.S. Geological Survey Geologic Quadrangle Map GQ-1070, scale 1:24,000.

747. Hedlund, D.C., and 0lson, J.C., 1974, Geologic map of the Iris NW Quadrangle, Gunnison and Saguache Counties, Colorado: U.S. Geological Survey Geologic Quadrangle Map GQ-1134, scale 1:24,000.

748. Hedlund, D.C., and 01son, J.C., 1975, Geologic map of the Powderhorn Quadrangle, Gunnison and Saguache Counties, Colorado: U.S. Geological Survey Geologic Quadrangle Map GQ-1178, scale 1:24,000.

749. Hedlund, D.C., and 01son, J.C., 1981, Precambrian geology along parts of the Gunnison Uplift of southwestern Colorado, in Epis, R.C., and Callender, J.F., eds., Western Slope, Colorado--Western Colorado and eastern Utah: [Socorro?], New Mexico Geological Society Guidebook 32, p. 267-272.

750. Heimes, F.J., Moore, G.K., and Steele, T.D., 1978, Preliminary applications of Landsat images and aerial photography for determining land-use, geologic, and hydrologic characteristics, Yampa River basin, Colorado and Wyoming: U.S. Geological Survey Water-Resources Investigations Report $78-96,48 \mathrm{p}$.

751. Heiss, H.W., 1979, Regional geology series--Part VII, The Colorado Plateau: National Water Well Association, Water Well Journal, v. 32, no. 10, p. 53-64. 
752. Helmke, G.L., 1955, White River Dome, Rio Blanco County, Colorado, in Ritzma, H.R., and Oriel, S.S., eds., Guidebook to the geology of northwest Colorado, Intermountain Association of Petroleum Geologists, 6 th annual field conference, and Rocky Mountain Association of Geologists annual field conference, 1985: Salt Lake City, Intermountain Association of Petroleum Geologists, p. 113-115.

753. Hem, J.D., 1985, Study and interpretation of the chemical characteristics of natural water (3d ed.): U.S. Geological. Survey Water-Supply Paper $2254,363 \mathrm{p}$.

754. Henderson, C.W., ed., 1932, Colorado: International Geological Congress Proceedings, Programme 16, $146 \mathrm{p}$.

755. Henderson, C.W., 1932, Geography, history, and mineral production of Colorado, in Henderson, C.W., ed., Colorado: International Geological Congress Proceedings, Programme 16, p. 1-5.

756. Henderson, J., 1914, Recent progress in Colorado paleontology and stratigraphy: [Denver?], Colorado Scientific Society Proceedings, v. 11, p. 5-22.

757. Henderson, J., 1923, The glacial geology of Grand Mesa, Colorado: Journal of Geology, v. 31, no. 8, p. 676-678.

758. Hendrickson, V.J., 1938, De Beque Anticline, Mesa County, Colorado: Mines Magazine, v. 28, no. 5, p. 198-199, 202, 234.

759. Henning, K.L., 1908, Streifzuege in den Rocky Mountains, der Mittelpark und der Gore Canyon [Expeditions in the Rocky Mountains, Middle Park and Gore Canyon]: Globus, no. 93, p. 312-318.

760. Henrich, Carl, 1889, Notes on the geology and on some of the mines of Aspen Mountain, Pitkin County, Colorado: American Institute of Mining Engineers Transactions, v. 17, p. 156-206.

762. Herman, George, and Barkel1, C.A., 1957, Pennsylvanian stratigraphy and productive zones, Paradox Salt basin: American Association of Petroleum Geologists Bulletin, v. 41, no. 5, p. 861-881.

763. Herr, R.G., Picard, M.D., and Evans, S.H., Jr., 1982, Age and depth of burial, Cambrian Lodore Formation, northeastern Utah and northwestern Colorado: Contributions to Geology, v. 21, no. 2, p. 115-121.

764. Herron, W.H., 1917, Profile surveys in the Colorado River basin in Wyoming, Utah, Colorado, and New Mexico: U.S. Geological Survey Water-Supply Paper 396, 6 p.

765. Hess, J.D., 1985, The geochemistry of silver in ground water: Bellingham, Western Washington State College, Master's thesis, unknown pagination.

766. Hess, M.E., 1984, Case study of a major agricultural control program--The Grand Valley experience, in French, R.H., ed., Salinity in watercourses and reservoirs--International Symposium on State-of-the-Art Control of Salinity, Salt Lake City, July 13-15, 1983, Proceedings: Boston, Butterworth Publishers, p. 285-294.

767. Heyman, 0.G., Huntoon, P.W., and White-Heyman, M.A., 1986, Laramide deformation of the Uncompahgre Plateau--Geometry and mechanisms, in Stone, D.S., and Johnson, K.S., eds., New interpretations of northwest Colorado geology: Denver, Rocky Mountain Association of Geologists Guidebook, p. 65-76.

768. Hill, J.M., 1909, Notes on the economic geology of southeastern Gunnison County in Chap. A of Contributions to economic geology, 1908--Part 1, metals and nonmetals except fuels: U.S. Geological Survey Bulletin 380, p. 21-40. 
769. Hill, V.S., 1984, Mississippian Williams Canyon Limestone Member of the Leadville Limestone, south-central Colorado: Golden, Colorado School of Mines, Master's thesis, $112 \mathrm{p}$.

770. Hills, R.C., 1886, Circulation of water through the strata of the upper Cretaceous coal measures of Gunnison County: [Denver?], Colorado Scientific Society Proceedings, v. 2, pt. 2, p. 127-133.

771. Hills, R.C., 1891, Post-Laramie beds of Middle Park: [Denver?], Colorado Scientific Society Proceedings, v. 4, p. 213-214.

772. Hite, R.J., 1968, Salt deposits of the Paradox Basin, southeast Utah and southwest Colorado, in Saline deposits: Geological Society of America Special Paper 88, p. 319-330.

773. Hite, R.J., 1970, Shelf carbonate sedimentation controlled by salinity in the Paradox Basin, southeast Utah, in Rau, J.L., and Dellwig, L.F., eds., Third Symposium on Salt: Cleveland, Northern Ohio Geological Society, v. 1, p. 48-66.

774. Hite, R.J., and Buckner, D.H., 1981, Stratigraphic correlations, facies concepts and cyclicity in Pennsylvanian rocks of the Paradox basin, in Wiegand, D.L., ed., Geology of the Paradox Basin: [Denver], Rocky Mountain Association of Geologists Field Conference, [Guidebook], v. 1981, p. 147-159.

775. Hite, R.J., and Lohman, S.W., 1973, Geologic appraisal of Paradox basin salt deposits for waste emplacement: U.S. Geological Survey Open-File Report 73-114, $75 \mathrm{p}$.

776. Hite, R.J., and Ruegger, B.F., 1986, Middle Pennsylvanian cyclic sedimentation in the Rocky Mountain region [abs.?]: American Association of Petroleum Geologists Bulletin, v. 70, no. 8, p. 1044.

777. Holland, W.T., and Jarvis, C.S., 1938, Inventory of unpublished hydrologic data: U.S. Geological Survey Water-Supply Paper 837, 77 p.

778. Hollenshead, C.T., and Pritchard, R.L., 1973, Geometry of producing Mesaverde sandstones, San Juan basin, in Sandstone reservoirs and stratigraphic concepts II: American Association of Petroleum Geologists Reprint Series 8, p. 4-24.

779. Holmes, W.F., 1979, Maps showing generalized structure contours on the tops of the Wasatch and Green River Formations, geologic sections, and contours of thickness of the Green River Formation, southeastern Uinta Basin, Utah and Colorado: U.S. Geological Survey Miscellaneous Investigations Series Map I-1156, scale 1:125,000.

780. Holmes, W.F., 1980, Results of test drilling for ground water in the southeastern Uinta Basin, Utah and Colorado: U.S. Geological Survey Water-Resources Investigations Open-File Report 80-951, $110 \mathrm{p}$.

781. Holmes, W.F., and Kimba11, B.A., 1983, Ground water in the southeastern Uinta Basin, Utah and Colorado: U.S. Geological Survey Open-File Report 83-271, $164 \mathrm{p}$.

782. Holmes, W.F., and Kimball, B.A., 1987, Ground water in the southeastern Uinta Basin, Utah and Colorado: U.S. Geological Survey Water-Supply Paper 2248, $47 \mathrm{p}$.

783. Holmes, W.H., 1876, Report on the geology of the northwestern portion of the Elk Range: U.S. Geological and Geographical Survey of the Territories (Hayden), Annual Report 8, p. 59-71.

784. Holmes, W.H., 1877, Report as geologist of the San Juan division: U.S. Geological and Geographical Survey of the Territories (Hayden), Annual Report 9, p. 237-276.

785. Holt, E.L., 1940, The Morrison and Summerville Formations (Jurassic) of the Grand River valley (Mesa County, Colorado) and their vertebrate fauna: Boulder, University of Colorado, Master's thesis, $71 \mathrm{p}$. 
786. Holt, H.E., 1961, Geology of the Lower Blue River area, Summit and Grand Counties, Colorado: Boulder, University of Colorado, Ph.D. dissertation, $107 \mathrm{p}$.

787. Honey, J.G., and Hettinger, R.D., 1989, Cross section showing correlations of Upper Cretaceous Fox Hills Sandstone and Lance Formation, and lower Tertiary Fort Union and Wasatch Formations, southeastern Washakie basin, Wyoming, and eastern Sand Wash basin, Colorado: U.S. Geological Survey Miscellaneous Investigations Series Map I-1964, scale not listed.

788. Honey, J.G., and Izett, G.A., 1988, Paleontology, taphonomy, and stratigraphy of the Browns Park Formation (Oligocene and Miocene) near Maybel1, Moffat County, Colorado: U.S. Geological Survey Professional Paper $1358,52 \mathrm{p}$.

789. Hood, J.W., 1976, Characteristics of aquifers in the northern Uinta Basin area, Utah and Colorado: U.S. Geological Survey Open-File Report 76-323, $81 \mathrm{p}$.

790. Hood, J.W., and Fields, F.K., 1977, Water resources of the northern Uinta Basin area, Utah and Colorado, with special emphasis on ground-water supply: U.S. Geological Survey Open-File Report 77-730, 105 p.

791. Hood, J.W., and Fields, F.K., 1978, Water resources of the northern Uinta Basin area, Utah and Colorado, with special emphasis on ground-water supply: Utah Department of Natural Resources Technical Publication 62, $63 \mathrm{p}$.

792. Hood, J.W., Mundorff, J.C., and Price, Don, 1976, Selected hydrologic data, Uinta Basin area, Utah and Colorado: Utah Basic Data Release 26, $321 \mathrm{p}$.

793. Hooper, Jane, 1940, Field geology and petrology of Tertiary basalt intrusions, Routt County, Colorado: Rochester, N.Y., University of Rochester, Master's thesis, unknown pagination.

794. Hoover, H.C., 1897, Geology of the Four-Mile placer mining district [abs.?]: Engineering and Mining Journal, v. 63, p. 510.

795. Hoover, W.B., 1950, Jurassic formations of parts of Utah, Colorado, Arizona and New Mexico, in Guidebook of the San Juan basin, New Mexico and Colorado--New Mexico Geological Society, 1st field conference, 1950: Socorro, New Mexico Geological Society, p. 76-81.

796. Hoover, W.B., 1952, Regional structure of the Four Corners area, in Wengard, S.A., ed., [1st] Geological symposium of the Four Corners region: [Durango, Colo.], Four Corners Geological Society, p. 10-11.

797. Horn, G.H., 1959, Geologic and structure map of the Maudlin Gulch, Temple Canyon, and Danforth Hills oil-fields and vicinity, Moffat County, Colorado: U.S. Geological Survey Open-File Map, scale 1:31,680.

798. Horn, G.H., and Adair, J.S., 1959, Geologic map of the Ragged Mountain coal area, Gunnison County, Colorado: U.S. Geological Survey Open-File Map, scale $1: 24,000$.

799. Horn, G.H., and Richardson, E.E., 1959, Geologic and structure map of the Williams Fork Mountains Coal Field, Moffat County, Colorado: U.S. Geological Survey Open-File Maps, scale 1:24,000.

800. Horton, R.A., Jr., 1985, Dolomitization and diagenesis of the Leadville Limestone (Mississippian), central Colorado: Golden, Colorado School of Mines, Ph.D. dissertation, $178 \mathrm{p}$.

802. Houck, K.J., 1987, Facies relationships in a regressive cycle from the Minturn Formation of north-central Colorado [abs.]: Geological Society of America Abstracts with Programs, v. 19, no. 5, p. 284. 
803. Houck, K.J., and Lockley, M.G., 1986, Pennsylvanian biofacies of the Minturn Formation, central Colorado: National North American Paleontological Convention, 4th, Boulder, Colo., Aug. 12-15, 1986, Proceedings 4, p. A20.

804. Houser, F.N., and Ekren, E.B., 1959, Cretaceous strata of the Ute Mountains area of southwestern Colorado, in Haun, J.D., and Weimer, R.J., eds., Symposium on Cretaceous rocks of Colorado and adjacent areas--Rocky Mountain Association of Geologists, 11th field conference, Washakie, Sand Wash, and Piceance basins, 1959: Denver, Rocky Mountain Association of Geologists, p. 145-152.

805. Houser, F.N., and Ekren, E.B., 1959, Preliminary geologic map of the Moqui SW Quadrangle, Montezuma County, Colorado: U.S. Geological Survey Mineral Investigations Field Studies Map MF-216, scale 1:24,000.

806. Howe, Ernest, 1905, Geology of the Ouray district, Colorado, in Irving, J.D., Ore deposits of the Ouray district, Colorado, in Emmons, S.F., and Hayes, C.W., geologists in charge, contributions to economic geology, 1904: U.S.Geological Survey Bulletin 260, p. 51-54.

807. Howell, J.V., 1919, Twin Lakes district of Colorado--Lake and Pitkin Counties: Colorado Geological Survey Bulletin 17, 108.p.

808. Hubert, J.F., 1954, Structure and stratigraphy of an area east of Brush Creek, Eagle County, Colorado: Boulder, University of Colorado, Master's thesis, $104 \mathrm{p}$.

809. Hudson, Kar1, 1948, The Ouray, Colorado, area: Rocks and Minerals, v. 25 , no. 8, p. $704-705$.

810. Huff, L.C., 1954, Sage Plain area, Utah, Colorado--Quadrangle mapping: U.S. Geological Survey Trace Element Investigations Report TEI-490, p. $39-40$.

811. Huff, L.C., 1955, Sage Plain area, Utah, Colorado--Quadrangle mapping: U.S. Geological Survey Trace Element Investigations Report TEI-540, p. 52-54.

812. Huff, L.C., 1955, Sage Plain area, Utah and Colorado: U.S. Geological Survey Trace Element Investigations Report TEI-590, p. 34-36.

813. Huff, L.C., and Lesure, F.G., 1956, Sage Plain area, Utah and Colorado: U.S. Geological Survey Trace Element Investigations Report TEI-640, p. 63-69.

814. Huff, L.C., and Lesure, F.G., 1957, Sage Plain area, Colorado, Utah: U.S. Geological Survey Trace Element Investigations Report TEI-690, book 1, p. 76-84.

815. Huffman, A.C., Jr., and Condon, S.M., 1989, New interpretations of Pennsylvanian and Permian stratigraphy, San Juan basin and southeast Paradox basin [abs.], in Barker, C.E., and Coury, A.B., comps., Abstracts of the U.S. Geological Survey, central region, 1989 poster review: U.S. Geological Survey Open-File Report 89-644, p. 7.

816. Hull, D.A., 1970, Geology of the Puzzle vein, Creede mining district (Mineral County), Colorado: Reno, University of Nevada, Ph.D. dissertation, $170 \mathrm{p}$.

817. Hunt, C.B., 1956, Cenozoic geology of the Colorado Plateau: U.S. Geological Survey Professional Paper 279, 99 p.

818. Hunt, C.B., 1956, Geology of the Taylor Site, Unaweep Canyon, Colorado, in Archaeological investigations on the Uncompahgre Plateau in westcentral Colorado: Denver Museum of Natural History Proceedings 2, p. 64-69.

819. Hunt, E.H., 1938, Geology of Wilson Creek Dome, Rio Blanco and Moffat Counties, Colorado: Mines Magazine, v. 28, no. 5, p. 192-195. 
820. Hunter, B.E., 1979, Regional analysis of the Point Lookout Sandstone, Upper Cretaceous, San Juan basin, New Mexico-Colorado: Lubbock, Texas Technical University, Ph.D. dissertation, unknown pagination.

821. Hunter, J.F., 1914, The Aberdeen granite quarry near Gunnison, Colorado, in chap. $\mathrm{K}$ of Contributions to economic geology, 1912--Part 1, Metals and nonmetals except fuels: U.S. Geological Survey Bulletin 540, p. 359-362.

822. Hunter, J.F., 1925, Pre-Cambrian rocks of Gunnison River, Colorado: U.S. Geological Survey Bulletin 777, 94 p.

823. Hunter, J.M., 1955, Geology of the North Hahns Peak area, Routt County, Colorado, in Ritzma, H.R., and Oriel, S.S., eds., Guidebook to the geology of northwest Colorado, Intermountain Association of Geologists, 6th annual field conference, and Rocky Mountain Association of Geologists annual field conference, 1955: Salt Lake City, Intermountain Association of Petroleum Geologists, p. 71-72.

824. Hurr, R.T., and Hearne, G.A., 1985, Colorado--Ground-water resources, in U.S. Geological Survey, comp., National water summary 1984, hydrologic events, selected water-quality trends, and ground-water resources: U.S. Geological Survey Water-Supply Paper 2275, p. 153-160.

825. Hurr, R.T., and Richards, D.B., 1966, Ground-water engineering of the Straight Creek Tunnel (pilot bore), Colorado: Engineering Geology, v. 3, nos. 1-2, p. 80-90.

826. Hutchinson, E.C., and Brogden, R.E., 1976, Water-quality data for the Southern Ute Indian Reservation, southwestern Colorado: U.S. Geological Survey Open-File Report 76-16, 2 sheets, scale 1:62,500.

827. Hynes, J.L., 1983, Geology of the Glenwood Canyon along I-70, in Hynes, J.L., ed., Proceedings of the 33d Annual Highway Geology Symposium-Engineering Geology and Environmental Constraints: [Denver?], Colorado Geological Survey Special Publication, v. 22, p. 136-146.

828. Inman, R.R., 01son, D.C., and King, D.L., 1984, Grand Valley salt pick-up calculations, in French, R.H., ed., Salinity in watercourses and reservoirs--International Symposium on State-of-the-Art Control of Salinity, Salt Lake City, July 13-15, 1983, Proceedings: Boston, Butterworth Publishers, p. 157-167.

829. Iorns, W.V., Hembree, C.H., and Oakland, G.L., 1965, Water resources of the Upper Colorado River Basin--Technical report: U.S. Geological Survey Professional Paper 441, 370 p.

830. Iradji, A.H., 1955, The geology of the northern Lenado area, Pitkin County, Colorado: Golden, Colorado School of Mines, Master's thesis, $98 \mathrm{p}$.

831. Irtem, Oguz, 1972, Stratigraphy of the Manitou Formation between Aspen and Minturn, Colorado: Golden, Colorado School of Mines, Master's thesis, $68 \mathrm{p}$.

832. Irtem, Oguz, 1977, Stratigraphy of the Minturn Formation (Pennsylvanian) between Glenwood Springs and Craig, Colorado: Golden, Colorado School of Mines, Ph.D. dissertation, 385 p.

833. Irving, J.D., and Bancroft, Howland, 1911, Geology and ore deposits near Lake City, Colorado: U.S. Geological Survey Bulletin 478, 128 p.

834. Irwin, C.D., 1986, Upper Cretaceous and Tertiary cross sections, Moffat County, Colorado, in Stone, D.S., and Johnson, K.S., eds., New interpretations of northwest Colorado geology: Denver, Rocky Mountain Association of Geologists Guidebook, p. 151-156.

835. Irwin, D., 1978, Subsurface cross sections of Colorado: [Denver], Rocky Mountain Association of Geologists Special Publication 2, 39 p. 
836. Irwin, J.H., 1966, Geology and availability of ground water on the Ute Mountain Indian Reservation, Colorado and New Mexico: U.S. Geological Survey Water-Supply Paper 1576-G, p. G1-G109.

837. Ives, R.L., 1938, Glacial geology of the Monarch Valley, Grand County, Colorado: Geological Society of America Bulletin, v. 49, no. 7, p. 1045-1066.

838. Izett, G.A., 1966, Tertiary extrusive volcanic rocks in Middle Park, Grand County, Colorado, in Geological Survey research 1966: U.S. Geological Survey Professional Paper 550-B, p. B42-B46.

839. Izett, G.A., 1968, Geology of the Hot Sulphur Springs Quadrangle, Grand County, Colorado: U.S. Geological Survey Professional Paper 586, 79 p.

840. Izett, G.A., 1974, Geologic map of the Trail Mountain Quadrangle, Grand County, Colorado: U.S. Geological Survey Geologic Quadrangle Map GQ-1156, scale $1: 24,000$.

841. Izett, G.A., and Barclay, C.S.V., 1964, Preliminary geologic map of the Hot Sulphur Springs SW Quadrangle, Grand County, Colorado: U.S. Geological Survey Mineral Investigations Field Studies Map MF-291, scale $1: 24,000$.

842. Izett, G.A., and Barclay, C.S.V., 1973, Geologic map of the Kremmling Quadrangle, Grand County, Colorado: U.S. Geological Survey Geologic Quadrangle Map GQ-1115, scale 1:62,500.

843. Izett, G.A., Cobban, W.A., and Gill, J.R., 1971, The Pierre Shale near Kremmling, Colorado, and its correlation to the east and the west: U.S. Geological Survey Professional Paper 684-A, 19 p.

844. Izett, G.A., Honey, J.G., and Brownfield, M.E., 1985, Geologic map of the Citadel Plateau Quadrangle, Moffat County, Colorado: U.S. Geological Survey Miscellaneous Investigations Series Map I-1532, scale 1:48,000.

845. Izett, G.A., and Hoover, D.L., 1963, Preliminary geologic map of the Hot Sulphur Springs SE Quadrangle, Grand County, Colorado: U.S. Geological Survey Mineral Investigations Field Studies Map MF-271, scale 1:24,000.

846. Izett, G.A., Taylor, R.B., and Hoover, D.L., 1963, Windy Gap Volcanic Member of the Middle Park Formation, Middle Park, Colorado, in Geological Survey research 1962: U.S. Geological Survey Professional Paper 450-E, p. E36-E39.

847. Jado, A.R., 1980, Paleogeographic interpretation of Permian units in northwestern Colorado and northeastern Utah, in Fouch, T.D., ed., Paleozoic paleogeography of the west-central United States--Rocky Mountain Paleogeography Symposium 1, 1980: [Denver?], Society of Economic Paleontologists and Mineralogists, Rocky Mountain Section, p. 293-304.

848. Jado, A.R.I., 1976, The stratigraphy and petrology of the Park City Formation in northwestern Colorado and northeastern Utah: Golden, Colorado School of Mines, Ph.D. dissertation, 263 p.

849. Jamison, W.R., 1979, Laramide deformation of the Wingate Sandstone, Colorado National Monument--A study of cataclastic flow: College Station, Texas A\&M University, Ph.D. dissertation, 181 p.

850. Jamison, W.R., and Stearns, D.W., 1982, Tectonic deformation of Wingate Sandstone, Colorado National Monument: American Association of Petroleum Geologists Bulletin, v. 66, no. 12, p. 2584-2608.

851. Jenkens, M.A., Jr., 1957, Stratigraphy of the Red Dirt Creek area, Grand County, Colorado, in Finch, W.C., ed., Guidebook to the geology of North and Middle Parks basin, Colorado: Denver, Rocky Mountain Association of Geologists, p. 51-54. 
852. Jensen, E.G., and Leach, R.W., 1984, Salinity control by pumping and deep well injection--The Paradox Valley unit, in French, R.H., ed., Salinity in watercourses and reservoirs--International Symposium on State-of-the-Art Control of Salinity, Salt Lake City, July 13-15, 1983, Proceedings: Boston, Butterworth Publishers, p. 349-358.

853. Jentgen, R.W., 1977, Pennsylvanian rocks in the San Juan basin, New Mexico and Colorado, in Fassett, J.E., ed., Guidebook of San Juan basin III, northwestern New Mexico: [Socorro?], New Mexico Geological Society, 28th field conference Guidebook, 1977, p. 129-132.

854. Jobin, D.A., 1953, Ground-water studies [Colorado Plateau]: U.S. Geological Survey Trace Element Investigations Report TEI-390, p. 35-36.

855. Jobin, D.A., 1954, Ground-water studies [Colorado Plateau]: U.S. Geological Survey Trace Element Investigations Report TEI-490, p. 48.

856. Jobin, D.A., 1954, Ground-water studies [Colorado Plateau]: U.S. Geological Survey Trace Element Investigations Report TEI-440, p. 35-36.

857. Jobin, D.A., 1955, Ground-water studies [Colorado Plateau]: U.S. Geological Survey Trace Element Investigations Report TEI-590, p. 90-97.

858. Jobin, D.A., 1955, Ground-water studies [Colorado Plateau]: U.S. Geological Survey Trace Element Investigations Report TEI-540, p. 65-72.

859. Joesting, H.R., and Byerly, P.E., 1956, Aeromagnetic and gravity profiles across the Uravan area, Colorado, in Geology and economic deposits of east-central Utah, Intermountain Association of Geologists, 7 th annual field conference, Guidebook: Salt Lake City, Intermountain Association of Petroleum Geologists, p. 38-41.

860. Joesting, H.R., and Byerly, P.E., 1958, Regional geophysical investigations of the Uravan area, Colorado: U.S. Geological Survey Professional Paper 316-A, p. 1-17.

861. Joesting, H.R., and Case, J.E., 1962, Regional geophysical studies in Salt Valley-Cisco area, Utah and Colorado: American Association of Petroleum Geologists Bulletin, v. 46, no. 10, p. 1879-1889.

862. Johnson, E.A., 1978, Geophysical logs for 18 holes drilled during 1977 in the Round Bottom area, Yampa Coal Field, Moffat County, Colorado: U.S. Geological Survey Open-File Report 78-229, 48 p.

863. Johnson, E.A., and Brown, Robert, 1979, Geophysical logs for six holes drilled during 1978 in the Round Bottom area, Yampa Coal Field, Moffat County, Colorado: U.S. Geological Survey Open-File Report 79-328, 24 p.

864. Johnson, E.A., and Brownfield, M.E., comps., 1985, Geologic map index of the Craig $1^{\circ}$ by $\frac{1}{2}^{\circ}$ Quadrangle, Moffat and Routt Counties, Colorado: U.S. Geological Survey Open-File Report 85-525, scale 1:100,000.

865. Johnson, E.A., and Brownfield, M.E., 1988, Regional correlation of the middle coal group of the Upper Cretaceous Mesaverde Group, Yampa Coal Field, Moffat and Routt Counties, Colorado: U.S. Geological Survey Coal Investigations Map C-123, scale not listed.

866. Johnson, J.H., 1924, Bibliography of the geology of southwestern Colorado: Golden, Colorado School of Mines Information Circular, Sept., 7 p.

867. Johnson, J.H., 1925, Bibliography of Colorado maps published by the State and Federal governments: Colorado School of Mines Quarterly, v. 20, no. $4,40 \mathrm{p}$.

868. Johnson, J.H., 1926, Bibliography of the geology and related subjects of northwestern Colorado--Revised to June 1, 1926: Colorado School of Mines Quarterly, v. 21, no. 3, 52 p.

869. Johnson, J.H., 1927, Bibliography of the geology of north-central Colorado: Colorado School of Mines Quarterly, v. 22, no. 4, 38 p. 
870. Johnson, J.H., 1938, Selected bibliography on the geology and petroleum possibilities of Colorado: Mines Magazine, v. 28, no. 5, p. 210-212, 224-228.

871. Johnson, J.H., 1945, Calcareous algae of the upper Leadville Limestone near Glenwood Springs, Colorado: Geological Society of America Bulletin, v. 56, no. 9, p. 829-847.

872. Johnson, J.H., 1945, Selected bibliography on Colorado petroleum geology and stratigraphy: Mines Magazine, v. 35, no. 4, p. 167-173.

873. Johnson, L.A., and Tuttle, G.E., 1977, Construction geology, Ruedi Dam and reservoir area, Colorado, in Veal, H.K., ed., Exploration frontiers of the central and southern Rockies: [Denver], Rocky Mountain Association of Geologists field conference [Guidebook], v. 1977, p. 461-464.

874. Johnson, R.C., 1975, Preliminary geologic map, oil shale yield histograms and stratigraphic sections, Long Point Quadrangle, Garfield County,

Colorado: U.S. Geological Survey Miscellaneous Field Studies Map MF-688, 2 sheets, scale 1:24,000.

875. Johnson, R.C., 1977, Preliminary geologic map and cross section of the Saddle Quadrangle Garfield County, Colorado: U.S. Geological Survey Miscellaneous Field Studies Map MF-829, scale $1: 24,000$.

876. Johnson, R.C., 1977, Preliminary geologic map of the Figure Four Spring Quadrangle, Rio Blanco and Garfield Counties, Colorado: U.S. Geological Survey Miscellaneous Field Studies Map MF-912, scale 1:24,000.

(Reprinted.)

877. Johnson, R.C., 1978, Cross section showing depositional environments and lithologies of some Upper Cretaceous and Tertiary rocks from De Beque to the north-central Piceance Creek basin, Colorado: U.S. Geological Survey Open-File Report 78-182, scale not listed.

878. Johnson, R.C., 1978, Supplementary cross sections and structure contour maps to the preliminary geologic map of the Figure Four Spring Quadrangle, Rio Blanco and Garfield Counties, Colorado: U.S. Geological Survey Open-File Report 78-197, 9 sheets, scale not listed.

879. Johnson, R.C., 1979, Cross section A-A' of Upper Cretaceous and lower Tertiary rocks, northern Piceance Creek basin, Colorado: U.S. Geological Survey Miscellaneous Field Studies Map MF-1129-A, 2 sheets, scale not listed.

880. Johnson, R.C., 1979, Cross section B-B' of Upper Cretaceous and lower Tertiary rocks, northern Piceance Creek basin, Colorado: U.S. Geological Survey Miscellaneous Field Studies Map MF-1129-B, 2 sheets, scale not listed.

881. Johnson, R.C., 1979, Cross section C-C' of Upper Cretaceous and lower Tertiary rocks, northern Piceance Creek basin, Colorado: U.S. Geological Survey Miscellaneous Field Studies Map MF-1129-C, 2 sheets, scale not listed.

882. Johnson, R.C., 1980, Preliminary geologic map of the Middle Dry Fork Quadrangle, Garfield County, Colorado: U.S. Geological Survey Miscellaneous Field Studies Map MF-1215, scale 1:24,000.

883. Johnson, R.C., 1981, Stratigraphic evidence for a deep Eocene Lake Uinta, Piceance Creek basin, Colorado: Geology (Boulder), v. 9, no. 2, p. 55-62.

884. Johnson, R.C., 1981, Preliminary geologic map of the Desert Gulch Quadrangle, Garfield County, Colorado: U.S. Geological Survey Miscellaneous Field Studies Map MF-1328, scale 1:24,000. 
885. Johnson, R.C., 1982, Measured section of the Upper Cretaceous Mesaverde Formation and lower part of the lower Tertiary Wasatch Formation, Rifle Gap, Garfield County, Colorado: U.S. Geological Survey Open-File Report $82-590,11 \mathrm{p}$.

886. Johnson, R.C., 1984, New names for units in the lower part of the Green River Formation, Piceance Creek basin, Colorado: U.S. Geological Survey Bulletin 1529-I, p. I1-I20.

887. Johnson, R.C., 1985, Preliminary geologic map of the Winter Flats Quadrangle, Garfield and Mesa Counties, Colorado: U.S. Geological Survey Miscellaneous Field Studies Map MF-1777, scale 1:24,000.

888. Johnson, R.C., 1985, Preliminary geologic map of the Baxter Pass Quadrangle, Garfield County, Colorado: U.S. Geological Survey Miscellaneous Field Studies Map MF-1813, scale 1:62,500.

889. Johnson, R.C., 1985, Early Cenozoic history of the Uinta and Piceance Creek basins, Utah and Colorado, with special reference to the development of Eocene Lake Uinta, in Flores, R.M., and Kaplan, S.S., eds., Cenozoic paleogeography of the west-central United States: Denver, Rocky Mountain Section, Society of Economic Paleontologists and Mineralogists Proceedings, p. 247-276.

890. Johnson, R.C., 1986, Structure contour map of the top of the Castlegate Sandstone, eastern part of the Uinta Basin and the western part of the Piceance Creek basin, Utah and Colorado: U.S. Geological Survey Miscellaneous Field Studies Map MF-1826, 2 sheets, scale 1:253,440.

891. Johnson, R.C., 1987, Geologic history and hydrocarbon potential of Late Cretaceous-age, low-permeability reservoirs, Piceance basin, western Colorado--Final report: U.S. Geological Survey and U.S. Department of Energy Report DOE/MC/20422-2337, 97 p.

892. Johnson, R.C., 1989, Detailed cross sections correlating Upper Cretaceous and lower Tertiary rocks between the Uinta Basin of eastern Utah and western Colorado and the Piceance basin of western Colorado: U.S. Geological Survey Miscellaneous Investigations Series Map I-1974, 2 sheets, scale not listed.

893. Johnson, R.C., 1989, Geologic history and hydrocarbon potential of Late Cretaceous-age, low-permeability reservoirs, Piceance basin, western Colorado: U.S. Geological Survey Bulletin 1787-E, p. E1-E51.

894. Johnson, R.C., and Douglas, B.J., 1980, Preliminary geologic map of the Wagon Track Ridge Quadrangle, Garfield and Mesa Counties, Colorado: U.S. Geological Survey Miscellaneous Field Studies Map MF-1182, scale $1: 24,000$.

895. Johnson, R.C., and Finn, T.M., 1986, Cretaceous through Holocene history of the Douglas Creek Arch, Colorado and Utah, in Stone, D.S., and Johnson, K.S., eds., New interpretations of northwest Colorado geology: Denver, Rocky Mountain Association of Geologists Guidebook, p. 77-95.

896. Johnson, R.C., Granica, M.P., and Dessenberger, N.C., 1979, Cross section $A-A^{\prime}$ of Upper Cretaceous and lower Tertiary rocks, southern Piceance Creek basin, Colorado: U.S. Geological Survey Miscellaneous Field Studies Map MF-1130-A, 2 sheets, scale not listed. (Reprinted.)

897. Johnson, R.C., Granica, M.P., and Dessenberger, N.C., 1979, Cross section B-B' of Upper Cretaceous and lower Tertiary rocks, southern Piceance Creek basin, Colorado: U.S. Geological Survey Miscellaneous Field Studies Map MF-1130-B, 2 sheets, scale not listed. (Reprinted.)

898. Johnson, R.C., Granica, M.P., and Dessenberger, N.C., 1979, Cross section C-C' of Upper Cretaceous and lower Tertiary rocks, southern Piceance Creek basin, Colorado: U.S. Geological Survey Miscellaneous Field Studies Map MF-1130-C, 2 sheets, scale not listed. (Reprinted.) 
899. Johnson, R.C., and Keighin, C.W., 1981, Cretaceous and Tertiary history and resources of the Piceance Creek basin, western Colorado, in Epis, R.C., and Callender, J.F., eds., Western Slope, Colorado--Western Colorado and eastern Utah: [Socorro?], New Mexico Geological Society Guidebook 32, p. 199-210.

900. Johnson, R.C., and May, Fred, 1978, [1979], Preliminary stratigraphic studies of the upper part of the Mesaverde Group, the Wasatch Formation, and the lower part of the Green River Formation, De Beque area, Colorado, including environments of deposition and investigations of palynomorph assemblages: U.S. Geological Survey Miscellaneous Field Studies Map MF-1050, 2 sheets, scale not listed.

901. Johnson, R.C., and May, Fred, 1980, A study of the Cretaceous-Tertiary unconformity in the Piceance Creek basin, Colorado--The underlying Ohio Creek Formation (Upper Cretaceous) redefined as a member of the Hunter Canyon or Mesaverde Formation: U.S. Geological Survey Bulletin 1482-B, $27 \mathrm{p}$.

902. Johnson, R.C., Nichols, D.J., and Hanley, J.H., 1988, Stratigraphic sections of lower Tertiary strata and charts showing palynomorph and mollusk assemblages, Douglas Creek Arch area, Colorado and Utah: U.S. Geological Survey Miscellaneous Field Studies Map MF-1997, 2 sheets, scale not listed.

903. Johnson, R.C., and Nuccio, V.F., 1984, Late Cretaceous through early Tertiary general stratigraphy and structural geology of the Piceance Creek basin, Colorado, in Spencer, C.W., and Keighin, C.W., eds., Geologic studies in support of the U.S. Department of Energy Multiwell Experiment, Garfield County, Colorado: U.S. Geological Survey Open-File Report 84-757, p. 14-20.

904. Johnson, R.W., 1955, Airborne radioactivity survey of part of Moffat County, Colorado, north of 40\%45': U.S. Geological Survey Geophysical Investigations Map GP-125, scale $1: 62,500$.

905. Johnson, R.W., 1955, Airborne radioactivity survey of part of Moffat County, Colorado, south of 40\%45': U.S. Geological Survey Geophysical Investigations Map GP-126, scale 1:62,500.

906. Johnson, S.Y., 1986, Fluvial transitions and paleogeography in upper part of Maroon Formation (Pennsylvanian and Permian), northwestern Colorado [abs.]: American Association of Petroleum Geologists Bulletin, v. 70, no. 8, p. 1045 .

907. Johnson, S.Y., 1987, Sedimentology and paleogeography of eolian deposits in the Maroon Formation (Pennsylvanian and Permian), Eagle basin, northwest Colorado [abs.]: Geological Society of America Abstracts and Programs, v. 19 , no. 5, p. 285.

908. Johnson, S.Y., 1987, Sedimentology and paleogeographic significance of six fluvial sandstone bodies in the Maroon Formation, Eagle basin, northwest Colorado, in Johnson, S.Y., Schenk, C.J., and Nuccio, V.F., Evolution of sedimentary basins--Uinta and Piceance basins: U.S. Geological Survey Bulletin 1787 A-C, p. 1-18.

909. Johnson, S.Y., 1987, Stratigraphic and sedimentologic studies of late Paleozoic strata in the Eagle basin and northern Aspen subbasin, northwest Colorado: U.S. Geological Survey Open-File Report 87-286, 82 p.

910. Johnson, S.Y., 1989, The Fryingpan Member of the Maroon Formation--A Lower Permian(?) basin-margin dune field in northwestern Colorado, in Nuccio, V.F., Johnson, R.C., and Johnson, S.Y., Variations in vitrinite reflectance Bulletin 1787-H, I, P. I1-I11. 
911. Johnson, S.Y., Schenk, C.J., and Karachewski, J.A., 1988, Pennsylvanian and Permian depositional systems and cycles in the Eagle basin, northwest Colorado, in Holden, G.S., ed., Geological Society of America Centennial Meeting, Denver, Field Trip Guidebook 1988: Professional Contributions of School of Mines 12, p. 156-175.

912. Johnson, S.Y., Schenk, C.J., and Nuccio, V.F., 1987, Evolution of sedimentary basins--Uinta and Piceance basins: U.S. Geological Survey Bulletin $1787 \mathrm{~A}-\mathrm{C}, 36 \mathrm{p}$.

913. Johnson, V.H., 1948, Geology of the Paonia Coal Field, Delta and Gunnison Counties, Colorado: U.S. Geological Survey Coal Investigations Map, scale $1: 48,000$.

914. Johnson, V.H., 1952, Thermal metamorphism and ground water alteration of coking coal near Paonia, Colorado: American Institute of Mining, Metallurgical, and Petroleum Engineers, Mining Engineering, v. 4, no. 4, p. 391-395.

915. Jones, J.R., Jr., 1984, Reservoir characterization for numerical simulation of Mesaverde meanderbelt sandstone, northwestern Colorado: University of Texas, Master's thesis, $115 \mathrm{p}$.

916. Jones, 0.M., 1914, Bibliography of Colorado geology and mining with subject index from earliest explorations to 1912: Colorado Geological Survey Bulletin 7, $493 \mathrm{p}$.

917. Jorgensen, D.G., and Signor, D.C., eds., 1984, Geohydrology of the Dakota aquifer--C.V. Theis Conference on Geohydrology, 1st, Lincoln, Nebr., Oct 5-6, 1982, Proceedings: Worthington, Ohio, National Water Well Association, $247 \mathrm{p}$.

918. Joseph, T.W., 1977, Annotated bibliography of natural resource information, northwestern Colorado: U.S. Fish and Wildlife Service Report FWS/OBS-77/35, $184 \mathrm{p}$.

919. Junge, W.R., 1978, Surficial geology, North Fork Gunnison River valley, Delta and Gunnison Counties, Colorado: Colorado Geological Survey Open-File Report 78-4, 7 plates, scale unknown.

920. Junge, W.R., 1982, Geologic hazards in the North Fork of the Gunnison River area, Delta and Gunnison Counties, Colorado, in Southeastern Piceance basin, western Colorado: [Grand Junction, Colo.?], Grand Junction Geological Society field trip, Sept. 25-26, 1982, [Guidebook?] , p. 83-86.

921. Kahn, J.J., and Longenbaugh, R.A., 1986, The Colorado experience in resolving surface-ground water conflicts, in American Society of Agricultural Engineers Symposium on Water Resources Law, 9th, Chicago, Dec. 15-16, 1986: American Society of Agricultural Engineers Proceedings 9, p. 76-83.

922. Kaiser, W.R., and Swartz, T.E., 1989, Fruitland Formation hydrology and producibility of coalbed methane in the San Juan basin, New Mexico and Colorado, in Proceedings of the 1989 coalbed methane symposium, Tuscaloosa, Ala., Apr. 17-20, 1989: Texas Bureau of Economic Geology, p. 87-97.

923. Kanizay, S.P., 1955, Geology of Cross Mountain, Moffat County, Colorado, in Ritzma, H.R., and Oriel, S.S., eds., Guidebook to the geology of northwest Colorado, Intermountain Association of Petroleum Geologists, 6 th annual field conference, and Rocky Mountain Association of Geologists annual field conference, 1955: Salt Lake City, Intermountain Association of Petroleum Geologists, p. 60-62.

924. Kanizay, S.P., 1956, Geology of Cross Mountain, Moffat County, Colorado: Golden, Colorado School of Mines, Ph.D. dissertation. 129 p. 
925. Kaufmann, R.F., 1981, Hydrogeologic influences on the long term disposal of uranium mill tailings, in Lawrence, C.R., ed., Proceedings of the groundwater pollution conference: Australian Water Resources Council Conference Series 1, p. 1-39.

926. Kehmeier, R.J., 1973, The geology and geochemistry of the Broken Hill area, Hinsdale County, Colorado: Golden, Colorado School of Mines, Master's thesis, $79 \mathrm{p}$.

927. Kelley, V.C., 1945, Geology, ore deposits, and mines of the Mineral Point, Poughkeepsie, and Upper Uncompahgre districts, Ouray, San Juan, Hinsdale Counties, [Colorado]: [Denver?], Colorado Scientific Society Proceedings, v. 14, no. 7, p. 287-466.

929. Kelley, V.C., 1955, Tectonics of the Four Corners region, in Cooper, J.C., ed., Geology of parts of Paradox, Black Mesa, and San Juan basins, [1st] Four Corners field conference, 1955 [Guidebook]: [Durango, Colo.], Four Corners Geological Society, p. 108-117.

930. Kelley, V.C., 1957, Geology of Ouray and environs, in Kottlowski, F.E., and Baldwin, Brewster, eds., Guidebook of southwestern San Juan Mountains, Colorado, 8th field conference, 1957: Socorro, New Mexico Geological Society, p. 203-207.

931. Kelley, V.C., 1957, General geology and tectonics of the western San Juan Mountains, Colorado, in Kittlowski, F.E., and Baldwin, Brewster, eds., Guidebook of southwestern San Juan Mountains, Colorado, 8th field conference, 1957: Socorro, New Mexico Geological Society, p. 154-162.

932. Kellogg, H.E., 1977, Geology and petroleum of the Mancos B Formation, Douglas Creek Arch, Colorado and Utah, in Veal, H.K., ed., Exploration frontiers of the central and southern Rockies: [Denver], Rocky Mountain Association of Geologists field conference [Guidebook], v. 1977, p. 167-179.

933. Kelly, K.E., 1982, Bailing and construction considerations for deep aquifer monitoring wells on western oil shale leases: Ground Water, v. 20 , no. 2 , p. 179-185.

934. Kendall, A.C., 1987, Early salt dissolution--Pennsylvanian of Paradox basin, Colorado and Utah [abs.], in Society of Economic Paleontologists and Mineralogists Annual Midyear Meeting, Austin, Tex., Aug. 20-23, 1987 : [Tulsa, Okla.?], Society of Economic Paleontologists and Mineralogists Abstracts 4, p. 41 .

935. Kent, B.H., and Arndt, H.H., 1980, Geology of the Thompson Creek coal mining area, Pitkin County, Colorado, as related to subsurface hydrualic mining potential: U.S. Geological Survey Open-File Report 80-507, 86 p.

936. Kent, B.H., and Arndt, H.H., 1980, Geology of the Carbondale coal mining area, Garfield and Pitkin Counties, Colorado, as related to subsurface hydraulic mining potential: U.S. Geological Survey Open-File Report 80-709, 99 p.

937. Kent, H.C., and Porter, K.W., eds, 1980, Colorado geology: Denver, Rocky Mountain Association of Geologists, $258 \mathrm{p}$.

938. Kerr, B.G., 1958, Geology of the Pagoda area, Routt and Moffatt Counties, northwestern Colorado: Golden, Colorado School of Mines, Master's thesis, $124 \mathrm{p}$.

939. Kietzke, K.K., and Lucas, S.G., 1984, Paleontological evidence of a non-marine, saline, model of deposition of the Jurassic Todilto Formation, northern New Mexico and southwestern Colorado: New Mexico Academy of Science Journal of Science, v. 24, no. 2, p. 24-25. 
940. Kilgore, L.W., 1955, Geology of the Duranga area, La Plata County, Colorado, in Cooper, J.C., ed., Geology of parts of Paradox, Black Mesa, and San Juan basins, [1st] Four Corners Geological Society field conference, 1955 [Guidebook]: [Durango, Colo.], Four Corners Geological Society, p. 118-124.

941. Kimball, B.A., 1976, Hydrogeology of the southeast Uinta Basin, Utah and Colorado: Cambridge, Mass., Harvard University, Bachelor's degree, 78 p.

942. Kimball, B.A., 1980, Geochemistry of spring water, southeastern Uinta Basin, Utah and Colorado: U.S. Geological Survey Open-File Report $80-417,68 \mathrm{p}$.

943. Kimball, B.A., 1981, Geochemistry of spring water, southeastern Uinta Basin, Utah and Colorado: U.S. Geological Survey Water-Supply Paper $2074,30 \mathrm{p}$.

944. Kimball, B.A., 1984, Ground water age determinations, Piceance Creek basin, Colorado, in Hitchon, Brian, and Wallick, E.I., eds., Proceedings of the First Canadian/American Conference on Hydrogeology--Practical applications of ground water geochemistry, Banff, Alberta, 1984: Worthington, Ohio, National Water Well Association, p. 267-283.

945. King, D.L., 1984, Grand Valley State one monitoring plan and implementation, in French, R.H., ed., Salinity in watercourses and reservoirs--International Symposium on State-of-the-Art Control of Salinity, Salt Lake City, July 13-15, 1983, Proceedings: Boston, Butterworth Publishers, p. 295-304.

946. Kirk, C.L., Byrd, W.J., Dow, R.L., and others, 1981, Bibliography of theses and dissertations on Colorado, 1968-1980: Mountain Geologist, v. 18 , no. 4, p. 96-113.

947. Kirkwood, S.G., 1976, Stratigraphy and petroleum potential of the Cedar Mountain and Dakota Formations, northwestern Colorado: Golden, Colorado School of Mines, Master's thesis, $193 \mathrm{p}$.

948. Kiteley, L.W., 1979, Stratigraphic measured sections of the Upper Cretaceous Mancos Shale (upper part) and Mesaverde Group (lower part), Moffat County, Colorado: U.S. Geological Survey Open-File Report $79-1306,48 \mathrm{p}$.

949. Kiteley, L.W., and Field, M.E., 1984, Shallow marine depositional environments in the Upper Cretaceous of northern Colorado, in Tillman, R.W., and Siemers, C.T., eds., Siliciclastic shelf sediments: [Tulsa, Okla.?], Society of Economic Paleontologists and Mineralogists Special Publication 34, p. 179-204.

950. Knapp, R.R., 1976, Depositional environments and diagenesis of the Nugget Sandstone, south-central Wyoming, northeast Utah and northwest Colorado: Laramie, Univeristy of Wyoming, Master's thesis, $67 \mathrm{p}$.

951. Knapp, R.R., 1978, Depositional environments and diagenesis of the Nugget Sandstone, south-central Wyoming, northeast Utah, and northwest Colorado, in Boyd, R.G., ed., Resources of the Wind River basin: [Laramie?] Wyoming Geologists Association Guidebook 30, p. 131-138.

952. Knutson, C.F., 1973, Preliminary hydrologic testing, in the collection Project Rio Blanco: Las Vegas, Nev., CER Geonuclear Corporation, various pagination.

953. Knutson, C.F., 1973, Evaluation of possible radioactivity transport in groundwater, in the collection Project Rio Blanco: Las Vegas, Nev., CER Geonuclear Corporation, various pagination.

954. Knutson, C.F., 1973, Hydrologic testing through January 30, 1973, in the collection Project Rio Blanco: Las Vegas, Nev., CER Geonuclear

Corporation, various pagination. 
955. Kocurek, G., 1981, Erg reconstruction--The Entrada Sandstone (Jurassic) of northern Utah and Colorado: Palaeogeography, Palaeoclimatology, Palaeoecology, v. 36, no. 1-2, p. 125-153.

956. Koelmel, M., 1985, Paleotectonic, stratigraphic, and diagenetic history of Weber Sandstone, Rangely area, Colorado [abs.?]: American Association of Petroleum Geologists Bulletin, v. 69, no. 5, p. 853.

957. Koesoemadinata, R.P., 1970, Stratigraphy and petroleum occurrence, Green River Formation, Red Wash Field, Utah: Colorado School of Mines Quarterly, v. 65, no. 1, 77 p.

958. Koksoy, Mumin, 1961, Geology of the northern part of Tincup mining district, Gunnison County, Colorado: Golden, Colorado School of Mines, Master's thesis, $99 \mathrm{p}$.

959. Konikow, L.F., 1977, Applications of solute-transport models to groundwater quality problems, in Wilkinson, W.B., ed., Groundwater quality--Measurement, prediction and protection: Medmenham, United Kingdom, Water Research Center Conference Proceedings, p. 625-652.

960. Konikow, L.F., and Bedinger, M.S., 1978, Evaluation of hydrogeologic aspects of proposed salinity control program in Paradox Valley, Colorado: U.S. Geological Survey Open-File Report 78-27, 56 p. [Available from U.S. Geological Survey, Water Resources Division, Box 25046, Mail Stop 413, Denver Federal Center, Denver, CO 80225-0046.]

961. Konishi, Kenji, 1959, Geology of the Iles Dome area, Moffat and Rio Blanco Counties, Colorado, and stratigraphic analysis of the Dakota Sandstone (Cretaceous) of northwestern Colorado: Golden, Colorado School of Mines, Master's thesis, 194 p.

962. Konishi, Kenji, 1959, Upper Cretaceous surface stratigraphy, Axial basin and Williams Fork area, Moffat and Routt Counties, Colorado, in Haun, J.D., and Weimer, R.J., eds., Symposium on Cretaceous rocks of Colorado and adjacent areas--Rocky Mountain Association of Geologists, 11th field conference, Washakie, Sand Wash, and Piceance basins, 1959: Denver, Rocky Mountain Association of Geologists, p. 67-73.

963. Konrad, D.E., 1977, State report--Colorado, in Orton, Lee, chairperson, annual conference of the Ground Water Management Districts Association, 4th Proceedings: Ground Water Management Districts Association v. 4, p. 65-66.

964. Kornegay, G.L., 1976, Lithologic, mineralogic and paleontologic variations in the Laney Member, Green River Formation, Sand Wash basin and southernmost Washakie basin, Colorado and Wyoming: Laramie, University of Wyoming, Master's thesis, 72 p.

965. Koschmann, A.H., 1958, The work of the U.S. Geological Survey in Colorado, 1945-1957: [Denver?], Colorado Mining Association Mining Year Book, p. 33-34.

966. Kostura, J.R., 1975, Stratigraphic and paleocurrent analysis of the Dakota Sandstone, Four Corners area of the San Juan basin, New Mexico, Colorado, Utah, and Arizona: Bowling Green, Ohio, Bowling Green State University, Master's thesis, unknown pagination.

967. Kottlowski, F.E., and Baldwin, Brewster, eds., 1957, Guidebook of southwestern San Juan Mountains, Colorado, 8th field conference, 1957: Socorro, New Mexico Geological Society, 258 p. 
968. Kraeger-Rovey, Catherine, and Butler, V.W., 1985, Application of a groundwater model for an oil shale mining operation in the Piceance basin, Colorado, in Morel-Seytoux, H.J., and Doehring, D.0., eds., Joint Proceedings of the fifth annual American Geophysical Union Front Range Branch hydrology days and the fourteenth annual Rocky Mountain groundwater conference, Fort Collins, Colo., Apr. 16-20, 1985: Fort Collins, Colo., Hydrology Days Publishing, p. 279-288.

969. Krasowski, D.J., 1976, Geology and ore deposits of Burrows Park, Hinsdale County, Colorado: Fort Collins, Colorado State University, Master's thesis, $111 \mathrm{p}$.

970. Krey, Max, 1962, North flank Uncompahgre Arch, Mesa and Garfield Counties, Colorado, in Mott, M.R., and Amuedo, C.L., eds., Exploration for oil and gas in northwestern Colorado: Denver, Rocky Mountain Association of Geologists Guidebook, p. 111-113.

971. Krieger, R.A., Hatchett, J.L., and Poole, J.L., 1957, Preliminary survey of the saline-water resources of the United States: U.S. Geological Survey Water-Supply Paper 1374, 172 p.

972. Kruse, E.G., 1978, Groundwater and salinity in the Grand Valley of Colorado, in 1978 Winter Meeting of the American Society of Agricultural Engineers, Chicago, December 18-20, 1978, [Proceedings?]: Chicago, American Society of Agricultural Engineers, 21 p.

973. Kucera, R.E., 1959, Cretaceous stratigraphy of the Yampa district, northwest Colorado, in Haun, J.D., and Weimer, R.J., eds., Symposium on Cretaceous rocks of Colorado and adjacent areas--Rocky Mountain Association of Geologists, 11th field conference, Washakie, Sand Wash, and Piceance basins, 1959: Denver, Rocky Mountain Association of Geologists, p. 1-8.

974. Kucera, R.E., 1962, Geology of the Yampa district (Routt, Rio Blanco, and Garfield Counties), northwest Colorado: Boulder, University of Colorado, Ph.D. dissertation, 2 v., 675 p.

975. Lakeotes, C.D., and Friesen, H.N., 1974, Hydrologic data bank users guide: Reno, Univeristy of Nevada, Desert Research Institute User Information Bulletin 4, $19 \mathrm{p}$.

976. Lakes, Arthur, 1887, Geology of the Aspen mining region: Golden, Colorado School of Mines Biennial Report 1886, p. 43-84.

977. Lakes, Arthur, 1895, Gunnison region [abs.?]: Colliery Engineer, v. 16, p. 267.

978. Lakes, Arthur, 1896, The San Juan region: Colliery Engineer, v. 17, p. 206-209.

979. Lakes, Arthur, 1897, The Needles, La Plata Mountains: Colliery Engineer, v. 18, p. 74-77, 101-103.

980. Lakes, Arthur, 1897, Peculiar formations in the San Juan region: Colliery Engineer, v. 17, p. 350-352.

981. Lakes, Arthur, 1898, The geology of Aspen and the conditions existing in the Smuggler Mine at the time of the fire: Mines and Minerals, v. 18, p. 251-253.

982. Lakes, Arthur, 1900, The La Plata Mountains of Colorado--A description of the telluride veins and the Mancos contact: Mines and Minerals, v. 20, p. 279-280.

983. Lakes, Arthur, 1902, Geology along the Animas River, with descriptions of coal and metal mines along its course, including a sketch of the Silver Lake Mine: Mines and Minerals, v. 22, p. 398-399.

984. Lakes, Arthur, 1905, The hot and mineral springs of Routt County and Middle Park, Colorado: Mining Reporter, v. 52, no. 18, p. 438-439. 
985. Lakes, Arthur, 1905, Geology of the hot springs of Colorado and speculations as to their origin and heat: [Denver?], Colorado Scientific Society Proceedings, v. 8, p. 31-37.

986. Lakes, Arthur, 1908, The general geology of Summit County: Mining and Science, v. 57, p. 243-244, 289-291.

987. Lakes, Arthur, 1911, Geology, mines, and ore deposits of Breckenridge: Mining and Science, v. 64, p. 388-391.

988. Langenheim, R.L., Jr., 1951, Pennsylvanian and Permian stratigraphy in the Crested Butte Quadrangle, Gunnison County, Colorado: St. Paul, University of Minnesota, Ph.D. dissertation. 179 p.

989. Langenheim, R.L., Jr., 1952, Pennsylvanian and Permian stratigraphy in Crested Butte Quadrangle, Gunnison County, Colorado: American

Association of Petroleum Geologists Bulletin, v. 36, no. 4, p. 543-574.

990. Langenheim, R.L., Jr., 1954, Correlation of Maroon Formation in Crystal River valley, Gunnison, Pitkin, and Garfield Counties, Colorado: American Association of Petroleum Geologists Bulletin, v. 38, no. 8, p. $1748-1779$.

991. Langenheim, R.L., Jr., 1957, Jurassic stratigraphy in Elk Mountains, west-central Colorado: American Association of Petroleum Geologists Bulletin, v. 41, no. 11 , p. 2576-2581.

992. Langenheim, R.L., Jr., 1978, Belden Shale sections at Fossil Ridge and Mosca, Gunnison County, Colorado: Earth Science Bulletin, v. 11, no. 4, p. $15-21$.

993. Larsen, E.S., Jr., 1911, The economic geology of Carson Camp, Hinsdale County, Colorado, in chap. B of Contributions to economic geology, 1910--Part 1, Metals and nonmetals, except fuels: U.S. Geological Survey Bulletin 470, p. 30-38.

994. Larsen, E.S., Jr., and Cross, C.W., 1956, Geology and petrology of the San Juan region, southwestern Colorado: U.S. Geological Survey Professional Paper 258, 303 p.

995. Larson, T.G., 1955, Stratigraphy of the Steamboat Springs area, Colorado, in Ritzma, H.R., and Oriel, S.S., eds., Guidebook to the geology of northwest Colorado, Intermountain Association of Geologists, 6th annual field conference, and Rocky Mountain Association of Geologists annual field conference, 1955: Salt Lake City, Intermountain Association of Petroleum Geologists, p. 10-11.

996. Lauman, G.W., 1965, Geology of the Iles Mountain area, Moffat County, northwestern Colorado: Golden, Colorado School of Mines, Master's thesis, $129 \mathrm{p}$.

997. Lauman, G.W., 1966, Geology of Williams Fork field, Moffat County, Colorado: Mountain Geologist, v. 3, no. 3, p. 99-113.

998. Lavington, C.S., 1938, Divide Creek Anticline, Garfield and Mesa Counties, Colorado: Mines Magazine, v. 28, no. 5, p. 203-206.

999. Law, B.E., 1984, Geologic characteristics of low-permeability gas reservoirs in greater Green River basin of Wyoming, Colorado, and Utah, in Sandstone reservoirs and stratigraphic concepts II: American Association of Petroleum Geologists AAPG Reprint Series 8, p. 498-499.

1000. Law, B.E., and Johnson, R.C., 1989, Structural and stratigraphic framework of the Pinedale Anticline, Wyoming, and the Multiwell Experiment site, Colorado, in Law, B.E., and Spencer, C.W., eds., Geology of tight gas reservoirs in the Pinedale Anticline area, Wyoming, and at the Multiwell Experiment site, Colorado: U.S. Geological Survey Bulletin 1886 , p. B1-B11. 
1001. Law, R.E., and Smith, C.R., 1983, Subsurface temperature map showing depth to 180 degrees Fahrenheit in the greater Green River basin of Wyoming, Colorado, and Utah: U.S. Geological Survey Miscellaneous Field Studies Map MF-1504, scale 1:500,000.

1002. Lay, H.C., 1902, Recent geological phenomena in the "Telluride Quadrangle" of the U.S. Geological Survey in Colorado: American Institute of Mining Engineers Transactions, v. 31, p. 558-567.

1003. Lease, R.C., 1971, Durango Fruitland area [abs.?], in Strippable lowsulfur coal resources of the San Juan basin in New Mexico and Colorado: [Socorro?], New Mexico Bureau of Mines and Mineral Resources Memoir 25, p. 102 .

1004. Lee, K., Prost, G.L., Knepper, D.H., Sawatsky, D.L., and Huntley, D., 1975, Geologic and mineral and water resources investigations in western Colorado, using Skylab EREP data report: 320 p. [Available from National Technical Information Service, U.S. Department of Commerce, Springfield, VA 22161 as N76-28593.]

1005. Lee, M.W., 1984, Vertical seismic profiles at the Multiwell Experiment site, Garfield County, Colorado: U.S. Geological Survey Open-File Report 84-168, $57 \mathrm{p}$.

1006. Lee, M.W., 1984, Delineation of lenticular-type sand bodies by the vertical seismic profiling method: U.S. Geological Survey Open-File Report 84-265, 92 p.

1007. Lee, M.W:, 1984, Detection and delineation of lenticular-type sand bodies by the vertical seismic profiling method, in spencer, C.W., and Keighin, C.W., eds., Geologic studies in support of the U.S. Department of Energy Multiwell Experiment, Garfield County, Colorado: U.S. Geological Survey Open-File Report 84-757, p. 121-134.

1008. Lee, M.W., 1985, Interpretation of azimuthal vertical seismic profile survey at Multiwell Experiment site, Garfield County, Colorado: U.S. Geological Survey Open-File Report 85-428, 47 p.

1009. Lee, M.W., 1986, An application of azimuthal vertical seismic profiles [abs.], in Carter, L.M., ed., USGS research on energy resources, 1986-Program and abstracts: U.S. Geological Survey Circular 974, p. 36.

1010. Lee, M.W., and Miller, J.J., 1985, Acquisition and processing of azimuthal vertical seismic profiles at Multiwell Experiment site, Garfield County, Colorado: U.S. Geological Survey Open-File Report $85-427,39 \mathrm{p}$.

1011. Lee, W.T., 1917, The geologic story of the Rocky Mountain National Park, Colorado: Washington, D.C., National Park Service, 89 p.

1012. Leenheer, J.A., 1981, Classification and fractionation of organic solutes in natural waters, in Greeson, P.E., ed., Organic substances in water: U.S. Geological Survey Circular 848-C, p. C11-C19.

1013. Leenheer, J.A., 1987, Chemical effects and control of wastes from in situ retorts, in Taylor, 0.J., comp., Oil shale, water resources, and valuable minerals of the Piceance basin, Colorado--The challenge and choices of development: U.S. Geological Survey Professional Paper 1310, p. 111-115.

1014. Leighton, C.D., 1987, Stratigraphy and sedimentology of the Pennsy1vanian Gothic Formation in the Crested Butte area, Colorado: Golden, Colorado School of Mines, Master's thesis, $195 \mathrm{p}$.

1015. Leighton, D.I., 1950, Geology of a portion of the Dillon Quadrangle, Colorado: Iowa City, Iowa State University, Master's thesis, unknown pagination. 
1016. Levorsen, M.K., 1987, Stratigraphic analysis of the Gothic Formation (Desmoinesian), Pitkin and Gunnison Counties, Colorado: Golden, Colorado School of Mines, Master's thesis, 135 p.

1017. Lickus, M.R., and Law, B.E., 1988, Structure contour map of the greater Green River basin, Wyoming, Colorado, and Utah: U.S. Geological Survey Miscellaneous Field Studies Map MF-2031, scale 1:500,000.

1018. Lindner-Lunsford, J.B., Kimball, B.A., Chafin, D.T., and Bryant, C.G., 1989, Hydrogeology of aquifers of Paleozoic age, Upper Colorado River Basin--excluding the San Juan basin--in Colorado, Utah, Wyoming, and Arizona: U.S. Geological Survey Hydrologic Investigations Atlas HA-702, 2 sheets, scale $1: 2,500,000$ and $1: 5,000,000$.

1019. Lindsey, D.A., Clark, R.F., and Soulliere, S.J., 1985, Minturn and Sangre de Cristo Formations of southern Colorado--Prograding fan-delta and alluvial-fan sequence shed from ancestral Rocky Mountains [abs.?]: American Association of Petroleum Engineers Bulletin, v. 69, no. 5, p. 854 .

1020. Lindskov, K.L., and Kimball, B.A., 1983, Water resources and potential hydrologic effects of oil-shale development in the southeastern Uinta Basin, Utah and Colorado: U.S. Geological Survey Open-File Report 83-0216, $100 \mathrm{p}$.

1021. Lindskov, K.L., and Kimball, B.A., 1984, Water resources and potential hydrologic effects of oil-shale development in the southeastern Uinta Basin, Utah and Colorado: U.S. Geological Survey Professional Paper $1307,32 \mathrm{p}$.

1022. Lindskov, K.L., and Kimball, B.A., 1984, Quantity and quality of streamflow in the southeastern Uinta Basin, Utah and Colorado: U.S. Geological Survey Water-Supply Paper 2224, 72 p.

1023. Lipman, P.W., 1968, Geology of the Summer Coon volcanic center, eastern San Juan Mountains, Colorado, in Cenozoic volcanism in the southern Rocky Mountains: Colorado School of Mines Quarterly, v. 63, no. 3, p. 211-236.

1024. Lipman, P.W., 1976, Geologic map of the Lake City caldera area, western San Juan Mountains, southwestern Colorado: U.S. Geological Survey Miscellaneous Investigations Series Map I-962, scale 1:48,000.

1025. Lipman, P.W., and Hail, W.J., Jr., 1975, Reconnaissance geologic map of the Chama Peak Quadrangle, Conejos and Archuleta Counties, Colorado: U.S. Geological Survey Miscellaneous Field Studies Map MF-682, scale 1:48,000. (Reprinted.)

1026. Litaor, M.I., 1987, Aluminum chemistry--Fractionation, speciation, and mineral equiplibria of soil interstitial water of an alpine watershed, Front Range, Colorado: Geochimica et Cosmochimica Acta, v. 51, no. 5, p. 1285-1295.

1027. Litke, D.W., and Appel, C.L., 1989, Estimated use of water in Colorado, 1985: U.S. Geological Survey Water-Resources Investigations Report $88-4101,157 \mathrm{p}$.

1028. Livesey, G.B., 1985, Laramide structures of southeastern Sand Wash basin, in Gries, R.R., and Dyer, R.C., eds., Seismic exploration of the Rocky Mountain region: Denver, Denver Geophysicists Society, p. 87-94.

1029. Loew, Oscar, 1875, Investigations upon mineralogical, agricultural and chemical conditions observed in portions of Colorado, New Mexico and Arizona, in 1873: Wheeler Survey Report, v. 3, p. 569-661.

1030. Lohman, S.W., 1960, Colorado National Monument and adjacent areas, in Guide to the geology of Colorado: [Denver], Rocky Mountain Association of Geologists, p. 86-88. 
1031. Lohman, S.W., 1963, Geologic map of the Grand Junction area, Colorado: U.S. Geological Survey Miscellaneous Geologic Investigations Map I-404, scale $1: 31,680$.

1032. Lohman, S.W., 1965, Geology and artesian water supply of the Grand Junction area, Colorado: U.S. Geological Survey Professional Paper 451, $149 \mathrm{p}$.

1033. Lohman, S.W., 1965, The geologic story of Colorado National Monument: [Fruita, Colo.], Colorado and Black Canyon Natural History Association, $56 \mathrm{p}$.

1034. Lohman, S.W., 1981, The geologic story of Colorado National Monument: U.S. Geological Survey Bulletin 1508, 142 p.

1035. Lohman, S.W., 1981, Ancient drainage changes in and south of Unaweep Canyon, southwestern Colorado, in Epis, R.C., and Callender, J.F., eds., Western Slope, Colorado--Western Colorado and eastern Utah: [Socorro?], New Mexico Geological Society Guidebook 32, p. 137-143.

1036. Lohman, S.W., and Petersen, M.S., 1972, Water, in Geologic atlas of the Rocky Mountain region: [Denver], Rocky Mountain Association of Geologists, p. 324-327.

1038. Lorenz, J.C., 1983, Lateral variability in the Corcoran and Cozzette blanket sandstones and associated Mesaverde rocks, Piceance Creek basin, northwestern Colorado, in Kersch, K.M., chairperson, Proceedings of the 1983 Society of Petroleum Engineers/Department of Energy joint symposium on low permeability gas reservoirs: [Dallas?], Society of Petroleum Engineers, p. 81-86.

1039. Lorenz, J.C., 1984, Reservoir sedimentology of Mesaverde rocks at the MWX site, in Spencer, C.W., and Keighin, C.W., eds., Geologic studies in support of the U.S. Department of Energy Multiwell Experiment, Garfield County, Colorado: U.S. Geological Survey Open-File Report 84-757, p. 21-32.

1040. Lorenz, J.C., 1989, Reservoir sedimentology of rocks of the Mesaverde Group, Multiwell Experiment site and east-central Piceance basin, northwest Colorado, in Law, B.E., and Spencer, C.W., eds., Geology of tight gas reservoirs in the Pinedale Anticline area, Wyoming, and at the Multiwell Experiment site, Colorado: U.S. Geological Survey Bulletin $1886, \mathrm{p} . \mathrm{K} 1-\mathrm{K} 24$.

1041. Lorenz, J.C., Heinze, D.M., Clark, J.A., and Searls, C.A., 1985, Determination of widths of meander-belt sandstone reservoirs from vertical downhole data, Mesaverde Group, Piceance Creek basin, Colorado: American Association of Petroleum Geologists Bulletin, v. 69, no. 5, p. 710-721.

1042. Lorenz, J.C., and Muhr, C.A., 1989, Slope-derived deposits from the Cretaceous Interior Seaway, northwestern Colorado: Sedimentary Geology, v. 61 , nos. 1-2, p. 69-85.

1043. Lorenz, J.C., and Rutledge, A.K., 1987, Late Cretaceous Mesaverde Group outcrops at Rifle Gap, Piceance Creek basin, northwestern Colorado, in Beus, S.S., ed., Rocky Mountain Section of the Geological Society of America: Boulder, Colo., Geological Society of America Centennial field guide, v. 2, p. 307-310.

1044. Lorenz, J.C., Sattler, A.R., and Stein, C.L., 1989, The effects of depositional environment on petrophysical properties of Mesaverde reservoirs, northwestern Colorado, in Tomich, J.F., ed., Omega--Formation evaluation and reservoir geology, Formation evaluation and reservoir geology, San Antonio, Tex., Oct. 8-11, 1989: [Da1las?], Society of Petroleum Engineers, Proceedings 64, p. 119-132. 
1045. Lovering, T.S., 1931, The Granby Anticline, Grand County, Colorado, in chap. B of Contributions to economic geology, 1930--Part 2, Mineral fuels: U.S. Geologica1 Survey Bulletin 822, p. 71-76.

1046. Lovering, T.S., 1932, Minturn to Florissant, in Henderson, C.W., ed., Colorado: International Geological Congress Proceedings, Programme 16, p. 66-69.

1047. Lovering, T.S., 1935, Geology and ore deposits of the Montezuma Quadrangle, Colorado: U.S. Geological Survey Professional Paper 178, $119 \mathrm{p}$.

1048. Lovering, T.S., and Behre, C.H., Jr., 1932, Battle Mountain (Red Cliff, Gilman) mining district, in Henderson, C.W., ed., Colorado:

International Geological Congress Proceedings, Programme 16, p. 69-77.

1049. Lovering, T.S., and Mallory, W.W., 1962, The Eagle Valley Evaporite and its relation to the Minturn and Maroon Formations, northwest Colorado, in Geological Survey research 1962: U.S. Geological Survey Professional Paper 450-D, p. D45-D48.

1050. Lowardy, L.D., 1911, Unwatering the silver mines of Aspen: Mining and Scientific Press, v. 63, p. 388-390.

1051. Lowther, W.H., and Knowles, R.R., 1910, The mineral waters of Steamboat Springs: Western Chemist and Metallurgist, v. 6, p. 60-65.

1052. Ludington, Steve, and Yeoman, R.A., 1980, Geologic map of the HunterFryingpan wilderness area and the Porphyry Mountain wilderness study area, Pitkin County, Colorado: U.S. Geological Survey Miscellaneous Field Studies Map MF-1236-A, scale 1:50,000.

1053. Ludlam, J.R., 1984, Geochemical characterization of the Mt. Harvard 15-Minute Quadrangle, Colorado, using NURE data: Grand Junction, Colo., Bendix Field Engineering Corporation Report GJBX-6(84), 26 p.

1054. Lueck, E.W., 1970, The geology of the Fulford mining district (Cenozoic), Eagle County, Colorado: Iowa City, University of Iowa, Master's thesis, unknown pagination.

1055. Luedke, R.G., 1972, Geologic map of the Wetterhorn Peak Quadrangle, Colorado: U.S. Geological Survey Geologic Quadrangle Map GQ-1011, scale $1: 24,000$.

1056. Luedke, R.G., and Burbank, W.S., 1962, Geology of the Ouray Quadrangle, Colorado: U.S. Geological Survey Geologic Quadrangle Map GQ-152, scale $1: 24,000$.

1057. Luedke, R.G., and Burbank, W.S., 1975, Preliminary geologic map of the Handie's Peak Quadrangle, Colorado: U.S. Geological Survey Open-File Report 75-431, scale $1: 20,000$.

1058. Luedke, R.G., and Burbank, W.S., 1975, Preliminary geologic map of the Howardsville Quadrangle, Colorado: U.S. Geological Survey Open-File Report 75-432, scale $1: 20,000$.

1059. Luedke, R.G., and Burbank, W.S., 1975, Preliminary geologic map of the Silverton Quadrangle, Colorado: U.S. Geological Survey Open-File Report 75-433, scale not listed.

1060. Luedke, R.G., and Burbank, W.S., 1976, Map showing types of bedrock and surficial deposits in the Telluride Quadrangle, San Miguel, Ouray, and San Juan Counties, Colorado: U.S. Geological Survey Miscellaneous Investigations Series Map I-973-A, scale 1:24,000.

1061. Luedke, R.G., and Burbank, W.S., 1977, Map showing potential geologic hazards in the Telluride Quadrangle, San Miguel, Ouray, and San Juan Counties, Colorado: U.S. Geological Survey Miscellaneous Investigations Series Map I-973-B, scale 1:24,000. 
1062. Luedke, R.G., and Burbank, W.S., 1981, Geologic map of the Uncompahgre (Ouray) mining district, southwestern Colorado: U.S. Geological Survey Miscellaneous Investigations Series Map I-1247, scale 1:12,000.

1063. Luedke, R.G., and Burbank, W.S., 1987, Geologic map of the Handies Peak Quadrangle, San Juan, Hinsdale and Ouray Counties, Colorado: U.S. Geological Survey Geologic Quadrangle Map GQ-1595, scale 1:24,000.

1064. Luft, S.J., 1985, Airfall tuff in the Browns Park Formation, northwestern Colorado and northeastern Utah: Mountain Geologist, v. 22, no. 3, p. 110-127.

1065. Luft, S.J., 1985, Generalized geologic map showing distribution and basal configuration of the Browns Park Formation and Bishop Conglomerate in northwestern Colorado, northeastern Utah, and southern Wyoming: U.S. Geological Survey Miscellaneous Field Studies Map MF-1821, scale $1: 250,000$.

1066. Luft, S.J., and Thoen, W.L., 1981, Measured sections of the Browns Park Formation (Miocene) in Moffat County, Colorado, 1980: U.S. Geological Survey Open-File Report 81-171, $37 \mathrm{p}$.

1067. Lundell, L.L., 1977, Depositional environment of the Eocene Green River Formation, Piceance Creek basin, Colorado: Laramie, University of Wyoming, Ph.D. dissertation, $147 \mathrm{p}$.

1068. Lusby, G.C., 1970, Hydrologic and biotic effects of grazing versus nongrazing near Grand Junction, Colorado, in Geological Survey research 1970: U.S. Geological Survey Professional Paper 700-B, p. B232-B236.

1069. Lusby, G.C., Reid, V.H., and Knipe, O.D., 1971, Effects of grazing on the hydrology and biology of the Badger Wash basin in western Colorado, 1953-66: U.S. Geological Survey Water-Supply Paper 1532-D, 90 p.

1070. Luttrel1, G.W., Hubert, M.L., and Murdock, C.R., comps., 1988, GEONAMES data base of geologic names of the United States through 1986--Colorado, New Mexico, and Arizona: U.S. Geological Survey Open-File Report 88-44-K, 11 p., 1 diskette.

1071. Lyford, F.P., 1979, Ground water in the San Juan basin, New Mexico and Colorado: U.S. Geological Survey Water-Resources Investigations 79-73, 22 p. [Available from National Technical Information Service, U.S. Department of Commerce, Springfield, VA 22161 as PB-80 108 020.]

1072. Lyford, F.P., Frenzel, P.F., and Stone, W.J., 1980, Preliminary estimates of effects of uranium-mine dewatering on water levels, San Juan basin, in Rautman, C.A., comp., Geology and mineral technology of the Grants uranium region, 1979: New Mexico Bureau of Mines and Mineral Resources Memoir 38, p. 320-333.

1073. Mack, G.H., and Rasmussen, K.A., 1984, Alluvial-fan sedimentation of the Cutler Formation (Permo-Pennsylvanian), near Gateway, Colorado: Geological Society of America Bulletin, v. 95, no. 1, p. 109-116.

1074. Mackay, I.H., 1953, Geology of the Thomasville-Woods Lake area, Eagle and Pitkin Counties, Colorado: Golden, Colorado School of Mines, Ph.D. dissertation, $121 \mathrm{p}$.

1075. Mackay, I.H., 1953, Geology of the Thomasville-Woods Lake area, Eagle and Pitkin Counties, Colorado: Colorado School of Mines Quarterly, v. 48, no. 4, 76 p.

1076. Macko, C.A., 1984, Glenwood-Dotsero Springs salinity control project, in French, R.H., ed., Salinity in watercourses and reservoirs-International Symposium on State-of-the-Art Control of Salinity, Salt Lake City, July 13-15, 1983, Proceedings: Boston, Butterworth Publishers, p. 295-304. 
1077. MacLachlan, M.E., 1989, Lexicon of Triassic to Pliocene stratigraphic units in field trip area, in Finch, W.I., Huffman, A.C., Jr., and Fassett, J.E., eds., Coal, uranium, and oil and gas in Mesozoic rocks of the San Juan basin--Anatomy of a giant energy-rich basin, in Coal and hydrocarbon resources of North America: Washington, D.C., American Geophysical Union, v. 1, chap. T120, p. 1-8.

1078. MacLachlan, M.E., and Welder, Frank, 1987, Paleozoic and Mesozoic formations and their potential as ground-water reservoirs, in Taylor, $0 . J .$, comp., Oil shale, water resources, and valuable minerals of the Piceance basin, Colorado--The challenge and choices of development: U.S. Geological Survey Professional Paper 1310, p. 95-106.

1079. MacQuown, W.C., Jr., 1945, Structure of the White River plateau near Glenwood Springs, Colorado: Geological Society of American Bulletin, v. 56 , no. 10 , p. $877-892$.

1080. Madden, D.H., 1979, Preliminary report on the Pierre Shale in North Park, Colorado, and its correlation to Boulder, Middle Park, and northwest Colorado: U.S. Geological Survey Open-File Report 79-729, 17 p.

1081. Madden, D.J., 1985, Description and origin of the lower part of the Mesaverde Group in Rifle Gap, Garfield County, Colorado: Mountain Geologist, v. 22, no. 3, p. 128-138.

1082. Madden-McGuire, D.J., 1989, Stratigraphy, depositional environments, and paleogeography of coal-bearing strata in the Upper Cretaceous Mesaverde Group, central Grand Hogback, Garfield County, Colorado: U.S. Geological Survey Professional Paper 1485, 45 p., 2 sheets.

1083. Madden-McGuire, D.J., and Newman, K.R., 1988, Stratigraphic distribution suggesting environmental significance of pollen in Late Cretaceous upper Iles and lower Williams Fork Formations, Rifle Gap, Garfield County, Colorado [abs.], in Barker, C.E., and Coury, A.B., comps., Abstracts of the U.S. Geological Survey, central region- 1988 poster review: U.S. Geological Survey Open-File Report 88-643, p. 14.

1084. Madole, R.F., 1982, Surficial geologic map of the Craig $\frac{1}{2}{ }^{\circ}$ by $1^{\circ}$ Quadrangle, Moffat and Routt Counties, Colorado: U.S. Geological Survey Miscellaneous Investigations Series Map I-1346, scale 1:100,000.

1085. Madole, R.F., 1982, Possible origins of till-like deposits near the summit of the Front Range in north-central Colorado: U.S. Geological Survey Professional Paper 1243, $31 \mathrm{p}$.

1086. Madole, R.F., 1984, Geology of the Pontiac Pit archeological site, Rocky Mountain National Park, Colorado: U.S. Geological Survey Open-File Report 84-223, $10 \mathrm{p}$.

1087. Madole, R.F., 1987, Geology of archeological sites in Middle Cottonwood Creek valley and Taylor Park, Chaffee and Gunnison Counties, Colorado: U.S. Geological Survey Open-File Report 87-78, 23 p.

1088. Maione, S.J., 1971, Stratigraphy of the Frontier Sandstone Member of the Mancos Shale (Upper Cretaceous) on the south flank of the eastern Uinta Mountains, Utah and Colorado: Golden, Colorado School of Mines, Master's thesis, $126 \mathrm{p}$.

1089. Maise, C.R., 1953, Groundwater circulation in a synclinal aquifer: U.S. Atomic Energy Commission Report RM0-44, p. 128-264.

1090. Major, T.J., 1977, Ground water use in Colorado, in Orton, Lee, chairperson, Annual conference of the Ground Water Management Districts Association, 4th, Proceedings: Ground Water Management Districts Association Proceedings, v. 4, p. 5-6.

1091. Major, T.J., Kerbs, Lynda, and Penley, R.D., 1975, Water-level records for Colorado, 1971-75: Colorado Water Resources Basic-Data Release 37, $356 \mathrm{p}$. 
1092. Malan, R.C., 1957, Geology of uranium occurrences in North and Middle Parks, Colorado, in Finch, W.C., ed., Guidebook to the geology of North and Middle Parks basin, Colorado: Denver, Rocky Mountain Association of Geologists, p. 126-136.

1093. Malan, R.C., and Ranspot, H.W., 1959, Geology of the uranium deposits in the Cochetopa mining district, Saguache and Gunnison Counties, Colorado: Economic Geology, v. 54, no. 1, p. 1-19.

1094. Mallory, M.W., 1977, Regional aspects of the Eagle Valley Evaporite, in Veal, H.K., ed., Exploration frontiers of the central and southern Rockies: [Denver], Rocky Mountain Association of Geologists field conference [Guidebook], v. 1977, p. 191-196.

1095. Mallory, W.W., 1954, Paleozoic stratigraphy of "The Four Corners region", Utah, Colorado, Arizona, New Mexico: Tulsa Geological Society Digest, v. 22, p. 90-93.

1096. Mallory, W.W., 1957, No. 10, Crested Butte measured section, in McKee, E.D., ed., Colorado measured sections--A symposium: Denver, Rocky Mountain Association of Geologists, p. 50-53.

1097. Mallory, W.W., 1958, Pennsylvanian coarse arkosic redbeds and associated mountains in Colorado, in Curtis, B.F., ed., Symposium on Pennsylvanian rocks of Colorado and adjacent areas, 1958: Denver, Rocky Mountain Association of Geologists, p. 17-20.

1098. Mallory, W.W., 1971, The Eagle Valley Evaporite, northwest Colorado--A regional synthesis: U.S. Geological Survey Bulletin 1311-E, $37 \mathrm{p}$.

1099. Mallory, W.W., 1988, Sedimentary rocks of the Eagle basin, in Holden, G.S., ed., Geological Society of America Centennial Meeting, Denver, Field Trip Guidebook 1988: Geological Society of America, Professional Contributions of the Colorado School of Mines 12, p. 112-114.

1100. Manfrino, Carrie, 1984, Stratigraphy and palynology of the upper Lewis Shale, Pictured Cliffs Sandstone and lower Fruitland Formation (Upper Cretaceous) near Durango, Colorado: Golden, Colorado School of Mines, Master's thesis, $96 \mathrm{p}$.

1101. Manfrino, Carrie, 1984, Stratigraphy and palynology of the upper Lewis Shale, Pictured Cliffs Sandstone, and lower Fruitland Formation (Upper Cretaceous) near Durango, Colorado: Mountain Geologist, v. 21, no. 4, p. 115-132.

1102. Manley, Kim, Scott, G.R., and Wobus, R.A., 1978, Preliminary geologic map of the Aztec $1^{\circ}$ by $2^{\circ}$ Quadrangle, northwestern New Mexico and southern Colorado: U.S. Geological Survey Open-File Report 78-466, 8 p.

1103. Manley, Kim, Scott, G.R., and Wobus, R.A., 1987, Geologic map of the Aztec $1^{\circ}$ by $2^{\circ}$ Quadrangle, northwestern New Mexico and southern Colorado: U.S. Geological Survey Miscellaneous Investigations Series Map I-1730, scale $1: 250,000$.

1105. Mark, Anson, 1958, Geology of the Illinois River-Buffalo Creek area, North Park (Jackson and Grand Counties), Colorado: Boulder, University of Boulder, Master's thesis, $72 \mathrm{p}$.

1106. Markley, D.E., Munson, S.D., and Dougan, P.M., 1980, Geohydrology and surface water hydrology programs of the Equity/DOE BX in situ oil shale project, Rio Blanco County, Colorado, in Gary, J.H., ed., Thirteenth Oil Shale Symposium Proceedings: Golden, Colorado School of Mines Press, p. 376-384.

1107. Marsh, 0.C., 1871, On the geology of the eastern Uinta Mountains: American Journal of Science, v. 1, p. 266-268.

1108. Marshal1, C.H., 1959, Photogeologic map of the Delta Quadrangle, Montrose and Delta Counties, Colorado: U.S. Geological Survey Miscellaneous Geologic Investigations Map I-282, scale 1:62,500. 
1109. Marsha11, C.H., 1959, Photogeologic map of the Norwood-1 Quadrangle, Montrose and Ouray Counties, Colorado: U.S. Geological Survey Miscellaneous Geologic Investigations Map I-283, scale 1:62,500.

1110. Marvine, A.R., 1874, Report on Middle Park region, Colorado: U.S. Geological and Geographical Survey of the Territories (Hayden) Annual Report 7, p. 83-192.

1111. Maslyn, R.M., 1977, Late-Mississippian paleokarst in the Aspen, Colorado, area: Golden, Colorado School of Mines, Master's thesis, $96 \mathrm{p}$.

1112. Maslyn, R.M., and Davis, D.G., 1979, Karst development on the White River Plateau, Colorado, in Werner, Eberhardt, ed., Alpine Karst Symposium--Geomorphology and geohydrology of alpine karst terrains in the Rocky Mountains, 1979: National Speleological Society Bulletin, v. 41, no. 3, p. 95-100.

1113. Matheny, M.L., 1957, Structures of southwest Paradox basin: World Oil, v. 145, no. 2, p. 63-67.

1114. Mather, K.F., and Wengerd, S.A., 1965, Pleistocene age of the "Eocene" Ridgway till, Colorado: Geological Society of America Bulletin, v. 76, no. 12 , p. 1401-1408.

1115. Matson, N.A., Jr., 1967, Geology of the Royal Mountain and Chief Mountain area, Summit County, Colorado: Boulder, University of Colorado, Master's thesis, $65 \mathrm{p}$.

1116. Mattox, R.B., 1968, Salt Anticline field area, Paradox basin, Colorado and Utah, in Saline deposits--International Conference on Saline Deposits, Houston, Texas, 1962, Proceedings: Geological Society of America Special Paper 88, p. 5-6.

1117. Maughan, E.K., 1980, Permian and Lower Triassic geology of Colorado, in Kent, H.C., and Porter, K.W., eds., Colorado geology: Denver, Rocky Mountain Association of Geologists, p. 103-110.

1118. Mayer, V.J., 1960, Stratigraphy and paleontology of the Mississippian formations of Moffat County, Colorado: Boulder, University of Colorado, Master's thesis, $111 \mathrm{p}$.

1119. Mayer, V.J., 1964, Stratigraphy and paleontology of the Mississippian formations of Moffat County, Colorado: Mountain Geologist, v. 1, no. 1, p. 25-34.

1120. Mayhew, J.D., 1969, Geology of the eastern part of the Bonanza volcanic field (Tertiary), Saguache County, Colorado: Golden, Colorado School of Mines, Master's thesis, $94 \mathrm{p}$.

1121. McCauley, C.A.H., 1878, The San Juan region--Annual report upon explorations and surveys in the department of the Missouri, by [E.H.?] Ruffner: [Washington, D.C.?] Annual Report to the Chief Engineer for 1878, Appendix SS, p. 1753-1852.

1122. McCauley, C.A.H., 1879, Notes on Pagosa Springs: American Journal of Science, ser. 3, v. 17, p. 497.

1123. McConaghy, J.A., 1966, A hydrogeologist looks at the 1965 Colorado ground-water law: Ground Water, v. 4, no. 2, p. 28-31.

1124. McConaghy, J.A., and Colburn, W.A., 1964, Records of wells in Colorado: Colorado Water Conservation Board, Basic Data Release 17, 384 p.

1125. McCord, J.P., 1984, Geologic overview, coal, and coalbed methane resources of the greater Green River coal region--Wyoming and Colorado, in Rightmire, C.T., Eddy, G.E., and Kirr, J.N., eds., Coalbed methane resources of the United States: American Association of Petroleum Geologists Studies in Geology 17, p. 271-293.

1126. McCue, J.J., 1955, Slater Dome, Moffat and Routt Counties, Colorado, in Green River basin: Wyoming Geological Association Guidebook, no. 10, p. 168-169. 
1127. McDonald, D.W., 1984, Sedimentary petrology and paleontology of part of the Hermosa Group (Pennsylvanian) between Durango and Silverton, Colorado: Monroe, Northeast Louisiana University, Master's thesis, $107 \mathrm{p}$.

1128. McElroy, J.R., 1953, Geology of the Derby Creek area, Eagle, Routt, and Garfield Counties, Colorado: Boulder, University of Colorado, Master's thesis, $78 \mathrm{p}$.

1129. McFarlan, A.C., 1961, Outline of the geology of the Cement Creek area, Gunnison County, Colorado, in Berg, R.R., and Rold, J.W., eds., Symposium on Lower and Middle Paleozoic rocks of Colorado, Rocky Mountain Association of Geologists, 12th field conference, 1961: Denver, Rocky Mountain Association of Geologists, p. 125-132.

1130. McGuinness, C.L., 1963, The role of ground water in the national water situation, with State summaries based on reports by district offices of the Ground Water Branch: U.S. Geological Survey Water-Supply Paper 1800, $1121 \mathrm{p}$.

1131. McGuinness, C.L., comp., 1964, Generalized map showing annual runoff and productive aquifers in the conterminous United States: U.S. Geological Survey Hydrologic Investigations Atlas HA-194, scale 1:5,000,000.

1132. McHugh, J.B., Ficklin, W.H., and Miller, W.R., 1988, Analytical results for 32 water samples from a hydrogeochemical survey of the Geneva Creek area, central Colorado: U.S. Geological Survey Open-File Report 88-365, $8 \mathrm{p}$.

1133. McIntosh, W.L, and Eister, M.F., 1972, Geologic map index of Colorado-Part B, 1953-1969: U.S. Geological Survey, scale 1:1,000,000.

1134. McKay, E.J., 1955, Geology of the Red Canyon Quadrangle, Colorado: U.S. Geological Survey Geologic Quadrangle Map GQ-58, scale 1:24,000.

1135. McKay, E.J., 1974, Geologic map of the Lone Mountain Quadrangle, Moffat County, Colorado: U.S. Geological Survey Geologic Quadrangle Map GQ-1144, scale $1: 62,500$.

1136. McKay, E.J., and Bergin, M.J., 1974, Geologic map of the Maybell Quadrangle, Moffat County, Colorado: U.S. Geological Survey Geologic Quadrangle Map GQ-1145, scale 1:62,500.

1137. McKay, E.J., and Jobin, D.A., 1954, Preliminary geologic map of the Atkinson Creek Quadrangle, Colorado: U.S. Geological Survey Mineral Investigations Field Studies Map MF-18, scale 1:24,000.

1138. McKnight, E.T., 1932, Rico district, in Henderson, C.W., ed., Colorado: International Geological Congress, Proceedings, Program 16, p. 63-64.

1139. McKnight, E.T., 1974, Geology and ore deposits of the Rico district, Colorado: U.S. Geological Survey Professional Paper 723, 100 p.

1140. McLaughlin, T.G., 1953, Ground water in Colorado and the status of investigations: Colorado Water Conservation Board Ground-Water Series Circular 4, 24 p. [2d printing 1956.]

1141. McLaughlin, T.G., 1956, Ground water in Colorado and the status of investigations: U.S. Geological Survey and Water Conservation Board, Ground-Water Series Circular 4, 24 p.

1142. McQueen, Kathleen, 1958, Photogeologic map of the Iris SE and Doyleville SW Quadrangles, Saguache County, Colorado: U.S. Geological Survey Miscellaneous Geologic Investigations Map I-277, scale 1:31,680.

1143. McWhorter, D.B., Rowe, J.W., Van Liew, M.W., and others, 1979, Surface and subsurface water quality hydrology in surface mined watersheds-Part I, Text: U.S. Environmental Protection Agency Report EPA-600/7-79-193A, 193 p. 
1144. McWhorter, D.B., Skogerboe, R.K., and Skogerboe, G.V., 1974, Potential of mine and mill spoils for water quality degradation, in water resources problems related to mining: Minneapolis, Minn., American Water Resources Association Proceedings 1, p. 123-137.

1145. McWhorter, D.B., Skogerboe, R.K., and Skogerboe, G.V., 1975, Water quality control in mine spoils, Upper Colorado River Basin: U.S. Environmental Protection Agency Report EPA-670/2-75-048, 99 p.

1146. Means, A.H., 1915, Geology and ore deposits of Red Cliff, Colorado: Economic Geology, v. 10, p. 1-27.

1147. Meeks, T.V., 1950, Reconnaissance of ground-water conditions in the Uncompahgre Valley, Colorado: U.S. Soil Conservation Service Regional Bulletin 112, Geologic Series 3, 27 p.

1148. Mehran, M., Narasimhan, T.N., and Fox, J.P., 1981, Hydrogeologic consequences of the modified in situ retorting process, Piceance Creek basin, Colorado, in [Gary, J.H., ed.?], Fourteenth Oil Shale Symposium Proceedings: Golden, Colorado School of Mines Press, p. 388-400.

1149. Meinzer, 0.E., 1927, Large springs in the United States: U.S. Geological Survey Water-Supply Paper 557, 94 p.

1150. Meissner, F.F., 1954, The geology of Spring Creek Park, Gunnison County, Colorado: Golden, Colorado School of Mines, Master's thesis, $150 \mathrm{p}$.

1151. Melancon, S.M., Hess, B.C., and Thomas, R.W., 1980, Assessment of energy resource development impact on water quality--The Yampa and White River basins: U.S. Environmental Protection Agency Report EPA-600/7-80-151, $168 \mathrm{p}$.

1152. Melancon, S.M., Michaud, T.S., and Thomas, R.W., 1979, Assessment of energy resource development impact on water quality--San Juan River basin: U.S. Environmental Protection Agency Report EPA-600/7-79-235, $152 \mathrm{p}$.

1153. Melbye, C.E., 1961, Resistivity method in groundwater exploration, City of Gunnison, Colorado: American Institute of Mining, Metallurgical, and Petroleum Engineers Transactions 1960, v. 217, p. 328-332.

1154. Melin, R.E., 1957, Selected annotated bibliography of the geology of sandstone-type uranium deposits in the United States: U.S. Geological Survey Bulletin 1059-C, p. 59-175.

1155. Merewether, E.A., comp., 1960, Geologic map of the igneous and metamorphic rocks of Colorado showing location of uranium deposits: U.S. Geological Survey Miscellaneous Geologic Investigations Map I-309, scale $1: 500,000$.

1156. Merin, I.S., and Michael, R.C., 1985, Application of structures mapped from Landsat imagery to exploration for stratigraphic traps in the Paradox basin, in Cook, J.J., and Morris-Jones, D.R., eds., Proceedings of the International Symposium on Remote Sensing of Environment--Remote sensing for exploration geology, San Francisco, Apr. 1-4, 1985: Ann Arbor, Mich., Environmental Research Institute, p. 183-192.

1157. Merriam, D.F., 1953, Tertiary geology of the Piceance basin, northwestern Colorado: Lawrence, University of Kansas, Master's thesis, unknown pagination.

1158. Merriam, D.F., 1954, Tertiary geology of the Piceance basin, northwestern Colorado: Compass, v. 31, no. 3, p. 154-171.

1159. Merrill, W.M., 1958, Molas and associated formations in San Juan basin-Needle Mountains area, southwestern Colorado: American Association of Petroleum Geologists Bulletin, v. 42, no. 9, p. 2107-2132.

1160. Metz, W.D., 1974, Oil shale--A huge resource of low-grade fuel: Science (American Association for the Advancement of Science), v. 184, no. 4143, p. 1271-1272. 
1161. Metzger, C.W., 1974, Geology, mineralization, and geochemistry of the upper Illinois River drainage basin, Grand and Jackson Counties, Colorado: Golden, Colorado School of Mines, Master's thesis, 92 p.

1162. Meyer, R.F., 1977, Geophysical logs of 22 holes drilled in 1976 in the Yampa Coal Field, Moffat County, northwestern Colorado: U.S. Geological Survey Open-File Report 77-118, 6 p.

1163. Meyer, R.F., 1978, Geophysical logs of 20 holes drilled in 1977 in the Yampa Coal Field, Hamilton, Horse Gulch, and Pagoda Quadrangles, Moffat County, Colorado: U.S. Geological Survey Open-File Report 78-366, 51 p.

1164. Meyer, R.F., and Brown, R.R., 1982, Geophysical logs of nine holes drilled in 1978 in the Yampa Coal Field, Hamilton and Pagoda Quadrangles, Moffat County, Colorado: U.S. Geological Survey Open-File Report 82-475, $34 \mathrm{p}$.

1165. Miall, A.D., 1988, Architectual elements and bounding surfaces in fluvial deposits--Anatomy of the Kayenta Formation (Lower Jurassic), southwest Colorado: Sedimentary Geology, v. 55, nos. 3-4, p. 233-262.

1166. Mial1, A.D., and Turner-Peterson, C.E., 1989, Variations in fluvial style in the Westwater Canyon Member, Morrison Formation (Jurassic), San Juan basin, Colorado Plateau: Sedimentary Geology, v. 63, nos. 1-2, p. 21-60.

1167. Michalski, T.C., and Richards, D.L., 1986, Catalog of Colorado and Nebraska cores housed at the USGS Core Repository, Denver, Colorado: U.S. Geological Survey Open-File Report 86-289, 60 p.

1168. Miles, C.H., 1961, The geology of the Pass Creek-Wolford Mountain area, Grand County, Colorado: Golden, Colorado School of Mines, Master's thesis, $89 \mathrm{p}$.

1169. Millberry, K.W., 1984, Fan-delta variations and associated shelf-bars, lower member of the Honaker Trail Formation (Desmoinesian), southwestern Colorado: [Austin?], University of Texas, Master's thesis, $62 \mathrm{p}$.

1170. Miller, A.E., 1975, Geologic, energy and mineral resources maps of Routt County, Colorado: Colorado Geological Survey Map Series 1, scale not listed.

1171. Miller, A.E., 1977, Geology of Moffat County, Colorado: Colorado Geological Survey Map Series 3, scale 1:126,720.

1172. Miller, J.D., and Opdyke, N.D., 1984, Magnetostratigraphy of the Red Sandstone Creek section, Vail, Colorado [abs?]: EOS, American Geophysical Union Transactions, v. 65, no. 16, p. 200.

1173. Miller, J.D., and Opdyke, N.D., 1985, Magnetostratigraphy of the Red Sandstone Creek section--Vail, Colorado: Geophysical Research Letters, v. 12 , no. 3 , p. 133-136.

1174. Miller, P.H., and Coale, B.V., 1969, Colorado National Monument--A fantastic landscape sculptured by erosion: Fruita, Colo., Colorado and Black Canyon of the Gunnison Nature Association, $73 \mathrm{p}$.

1175. Molenaar, C.M., 1975, Some notes on Upper Cretaceous stratigraphy of the Paradox basin, in Canyonlands Country, Four Corners Geological Society, 8th field conference, Guidebook: [Durango, Colo.], p. 191-192.

1176. Molenaar, C.M., 1977, Stratigraphy and depositional history of Upper Cretaceous rocks of the San Juan basin area, New Mexico and Colorado, with a note on economic resources, in Fassett, J.E., ed., Guidebook of the San Juan basin III, northwestern New Mexico: [Socorro?], New Mexico Geological Society, 28th field conference, 1977, p. 159-166. 
1177. Molenaar, C.M., 1978, Stratigraphic nomenclature charts for San Juan and Paradox basins, in Fassett, J.E., ed., 0il and gas fields of the Four Corners area: [Durango, Colo.], Four Corners Geological Society, p. 40-41.

1178. Molenaar, C.M., 1981, Mesozoic stratigraphy of the Paradox basin--An overview, in Wiegand, D.L., ed., Geology of the Paradox basin: [Denver], Rocky Mountain Association of Geologists field conference, [Guidebook], v. 1981, p. 119-127.

1179. Molenaar, C.M., 1983, Major depositional cycles and regional correlations of Upper Cretaceous rocks, .southern Colorado Plateau and adjacent areas, in Reynolds, M.W., ed., Mesozoic paleogeography of the west-central United States: [Denver?], Rocky Mountain Paleogeography Symposium, v. 2, p. 201-224.

1180. Molenaar, C.M., 1988, Stratigraphic cross section showing Upper Cretaceous rocks across the San Juan basin, New Mexico and Colorado [abs.], in Fassett, J.E., ed., Geology and coal-bed methane resources of the northern San Juan basin, Colorado and New Mexico: Denver, Rocky Mountain Association of Geologists, p. 21.

1181. Molenaar, C.M., 1989, Stratigraphy and correlation of Middle Cretaceous rocks around Uinta Basin, northeastern Utah and northwestern Colorado [abs.], in Barker, C.E., and Coury, A.B., comps., Abstracts of the U.S. Geological Survey, central region, 1989 poster review--Collected abstracts of selected papers presented at scientific meetings: U.S. Geological Survey Open-File Report 89-644, p. 9.

1182. Molenaar, C.M., and Baird, J.K., 1989, North-south stratigraphic cross sections of Upper Cretaceous rocks, northern San Juan basin, southwestern Colorado: U.S. Geological Survey Miscellaneous Field Studies Map MF-2068, 3 sheets, scale $1: 633,600$.

1183. Molenaar, C.M., Craig, L.C., Chenoweth, W.L., and others, 1981, First day--Road $\log$ from Grand Junction to Whitewater, Unaweep Canyon, Uravan, Paradox Valley, La Sal, Arches National Park, and return to Grand Junction via Crescent Junction, Utah, in Epis, R.C., and Callender, J.F., eds., Western Slope, Colorado--Western Colorado and eastern Utah:

[Socorro?], New Mexico Geological Society Guidebook 32, p. 1-16.

1184. Molenaar, C.M., and Wilson, B.W., 1988, The Frontier Formation and associated rocks of northeastern Utah and northwestern Colorado [abs.], in Barker, C.E., and Coury, A.B., comps., Abstracts of the U.S. Geological Survey, central region--1988 poster review: U.S. Geological Survey Open-File Report 88-643, p. 15.

1185. Moore, D.W., and Gillam, M.L., 1984, Road log--Quaternary deposits and soils in the Durango area, southwestern Colorado, in Brew, D.C., ed., Paleotectonics, San Juan Mountains *t* Durango area; Geological Society of America, Rocky Mountain Section, 37 th annual meeting, Durango, Colo., 1984: Durango, Colo., Four Corners Geological Society, Geological Society of America Field Trip Guidebook 1, 3-5, p. 183-209.

1186. Moore, D.W., and Scott, G.R., 1981, Generalized surficial geologic map of the Basin Mountain Quadrangle, Colorado: U.S. Geological Survey Open-File Report 81-1306, scale 1:24,000.

1188. Morrison, R.B., 1965, Route from Denver, Colorado, to Salt Lake City, Utah via the Denver and Rio Grande Western Railroad (Moffat Tunnel Route)--1st day, 1st field conference, Guidebook, 7 th Congress, International Association of Quaternary Research Supplement, 1965: Lincoln, Nebraska Academy of Science, $68 \mathrm{p}$.

1189. Morrison, R.S., 1874, The San Juan country: Mining Review, v. 3, no. 3, p. $27-28$. 
1190. Motica, J.E., 1968, Geology and uranium-vanadium deposits in the Uravan mineral belt, southwestern Colorado, in Ore deposits of the United States, 1933-1967 (Graton-Sales Volume), v. 1: New York, American Institute of Mining, Metallurgical and Petroleum Engineers, p. 805-813.

1191. Moulder, E.A., 1960, A plan for the practical management of the water resources in an alluvial valley: U.S. Geological Survey Open-File Report.

1192. Moulder, E.A., and Jenkins, C.T., 1964, Methods for controlling the ground-water regime exploitation and conservation [with French abstract]: [Louvain, Belg.?], International Association of Scientific Hydrology Publication 64, p. 329-342.

1193. Mueller, P.M., 1958, Geology of Cross Mountain, Colorado, north of the Yampa River: Compass, v. 36, no. 1, p. 2-22.

1194. Mul1, C.G., 1960, Geology of the Grand Hogback Monocline near Rifle (Garfield County), Colorado: Boulder, University of Colorado, Master's thesis, $189 \mathrm{p}$.

1195. Mullens, M.C., 1973, Bibliography of the geology of the Green River Formation, Colorado, Utah, and Wyoming, to March 1, 1973: U.S. Geological Survey Circular 675, 20 p.

1196. Mullens, M.C., 1976, Structure contours and overburden on the top of the Mahogany Zone, Green River Formation, in the southern part of Piceance Creek basin, Rio Blanco and Garfield Counties, Colorado: U.S. Geological Survey Miscellaneous Field Studies Map MF-746, scale 1:63,360.

1197. Mullens, M.C., 1977, Bibliography of the geology of the Green River Formation, Colorado, Utah, and Wyoming, to March 1, 1977: U.S. Geological Survey Circular 754, $52 \mathrm{p}$.

1198. Muller, S.C., 1976, Lithologic and geophysical logs of seven holes drilled in 1975 in the Yampa and Danforth Hills Coal Fields, northwestern Colorado: U.S. Geological Survey Open-File Report 76-383, 180 p.

1199. Murphy, J.H., 1951, Geology of the upper Cement Creek area of Gunnison County, Colorado, and a petrological study of the Maroon Formation: Lexington, University of Kentucky, Master's thesis, $49 \mathrm{p}$.

1200. Murray, D.K., Chronic, John, De Voto, R.H., and others, 1968, Index of graduate theses and dissertations on Colorado geology by in-State tuitions, 1905 through 1967: Mountain Geologist, v. 5, no. 2, p. 45-67.

1201. Murray, D.K., and Haun, J.D., 1974, Introduction to the geology of the Piceance Creek basin and vicinity, northwestern Colorado, in Murray, D.K., ed., Energy resources of the Piceance Creek basin, Colorado: Denver, Rocky Mountain Association of Geologists, 25th field conference guidebook, p. 29-39.

1202. Murray, F.N., 1962, The geology of the Grand Hogback Monocline near Meeker (Rio Blanco County), Colorado: Boulder, University of Colorado, Master's thesis, $139 \mathrm{p}$.

1203. Murray, F.N., 1966, Stratigraphy and structural geology of the Grand Hogback Monocline (Rio Blanco, Garfield, Pitkin, and Gunnison Counties), Colorado: Boulder, University of Colorado, Ph.D. dissertation, $219 \mathrm{p}$.

1204. Murray, H.F., 1950, Pennsylvanian stratigraphy of Eagle County, Colorado: Boulder, University of Colorado, Master's thesis, $62 \mathrm{p}$.

1206. Mutschler, F.E., 1968, Geology of the Treasure Mountain Dome, Gunnison County, Colorado: Boulder, University of Colorado, Ph.D. dissertation, $240 \mathrm{p}$.

1207. Mutschler, F.E., 1970, Geologic map of the Snowmass Mountain Quadrangle, Pitkin and Gunnison Counties, Colorado: U.S. Geological Survey Geologic Quadrangle Map GQ-853, scale 1:24,000. 
1208. Nadeau, J.E., 1972, The stratigraphy of the Leadville Limestone, central Colorado: Pullman, Washington State University, Ph.D. dissertation, unknown pagination.

1209. Nadeau, Joseph, 1972, Mississippian stratigraphy of central Colorado, in Paleozoic stratigraphy and structural evolution of Colorado: Colorado School of Mines Quarterly, v. 67, no. 4, p. 77-101.

1210. National Water Well Association, 1986, Summary of State ground water quality monitoring well regulations--EPA Region VIII: Dublin, Ohio, National Water Well Association, $50 \mathrm{p}$.

1211. Nelson, K., and Scott A.J., 1984, Late Cretaceous (Campanian) estuarine and fluvial systems associated with rapid subsidence, northwestern Colorado [abs.?], in Stott, D.F., and Glass, D.J., eds., The Mesozoic of middle North America, Symposium in the Mesozoic of middle North America, Calgary, Alberta, Canada, May 8-13, 1983, Proceedings: Calgary, Canadian Society of Petroleum Geologists Memoir 9, p. 560.

1212. Nelson, K.H., 1984, Estuarine and anastomosing fluvial systems of the lower Mesaverde Group, northwestern Colorado: [Austin?], University of Texas, Master's thesis, $151 \mathrm{p}$.

1213. Nelson, K.R., 1971, The geology and geochemistry of the Poison Ridge intrusive center (Tertiary), Grand and Jackson Counties, Colorado: Golden, Colorado School of Mines, Master's thesis, 79 p.

1214. Nelson, K.R., 1971, The geology and geochemistry of the Poison Ridge intrusive center, Grand and Jackson Counties, Colorado: Mountain Geologist, v. 8, no. 2, p. 45-70.

1215. Neuerburg, G.J., 1971, Maps showing soil analyses of interest for prospecting the Montezuma Stock, Summit County, Colorado: U.S. Geological Survey Miscellaneous Investigations Series Map I-634, scale $1: 31,680$.

1216. Neuerburg, G.J., 1971, Maps showing distribution of selected accessory minerals in the Montezuma Stock, Summit County, Colorado: U.S. Geological Survey Miscellaneous Investigations Series Map I-608, scale $1: 31,680$.

1217. New Mexico Geological Society, 1951, Guidebook of the south and west sides of the San Juan basin, New Mexico and Arizona, 2d field conference, 1951: [Socorro?], New Mexico Geological Society, 167 p.

1219. New Mexico Geological Society, and Shomaker, J.W., eds., 1968, Guidebook of San Juan-San Miguel-La Plata region, New Mexico and Colorado, 19th field conference, 1968: Socorro, New Mexico Bureau of Mines and Mineral Resources, $211 \mathrm{p}$.

1220. Newman, K.R., 1965, Mancos to Wasatch measured section in Meeker-Rio Blanco area, northwestern Colorado: Mountain Geologist, v. 2, no. 3, p. $135-139$.

1221. Newman, K.R., 1982, Stratigraphic framework of Upper Cretaceous (Campanian) coal in western Colorado, in Grand Junction Geological Society, Southeastern Piceance basin, western Colorado: [Grand Junction, Colo.?], Grand Junction Geological Society, p. 61-64.

1222. Newman, K.R., 1987, Late Maastrichtian (Cretaceous) palynomorph age of "Ohio Creek" Congomerate, eastern Piceance Creek basin, Colorado [abs.]: Geological Society of America, Rocky Abstracts with Programs, v. 19, no. 5 , p. 323 .

1223. Newman, W.L., and Elston, D.P., 1959, Distribution of chemical elements in the Salt Wash Member of the Morrison Formation, Jo Dandy area, Montrose County, Colorado: U.S. Geological Survey Bulletin 1084-E, p. $117-150$. 
1224. Newton's, 1880, Gunnison and Eagle River Counties: Denver, The Chain and Hardy Company, 1 p. [Map.]

1225. Newton, S.M., 1946, Porosity and permeability as related to the Weber Sandstone, Rangely oil field, Rio Blanco County, Colorado [abs.?]: [Denver?], Rocky Mountain Petroleum Yearbook, p. 69.

1226. Newton, S.M., 1947, Rangely faults; oil and gas field, Colorado: [Denver?], Rocky Mountain Petroleum Review, p. 32-36.

1227. Newton, W.A., 1964, A geologic evaluation of the proposed Ruedi dam and reservoir, Eagle County, Colorado: Mountain Geologist, v. 1, no. 2, p. 73-77.

1228. Nicolais, S.M., 1975, Geology of the South Ophir district, San Juan and San Miguel Counties, Colorado: Golden, Colorado School of Mines, Master's thesis, $174 \mathrm{p}$.

1229. Noe, D.C., 1984, Variations in shoreline sandstones from a Late Cretaceous interdeltaic embayment, Sego Sandstone (Campanian), northwestern Colorado: [Austin?], University of Texas, Master's thesis, $127 \mathrm{p}$.

1230. Nol1, M.D., and Archibald, J.D., 1987, Preliminary sedimentology and biostratigraphy, Upper Cretaceous Williams Fork Formation (Mesaverde Group), Rio Blanco County, Piceance Creek basin, NW Colorado [abs.]: Abstracts with Programs, v. 19, no. 5, p. 324.

1231. Noon, P.L., 1980, Surface to subsurface stratigraphy of the Dakota Sandstone (Cretaceous) and adjacent units along the eastern flank of the San Juan basin, New Mexico and Colorado: Bowling Green, Ohio, Bowling Green State University, Master's thesis, $133 \mathrm{p}$.

1232. Norton, S.A., Hess, C.T., Blake, G.M., Morrison, M.M., and Baron, J., 1985, Excess unsupported (210) $\mathrm{Pb}$ in lake sediment from Rocky Mountain lakes--A groundwater effect: Canadian Journal of Fisheries and Aquatic Sciences, v. 42, no. 7, p. 1249-1254.

1233. Nuccio, V.F., 1985, Preliminary geologic map of the Douglas Pass Quadrangle, Garfield County, Colorado: U.S. Geological Survey Miscellaneous Field Studies Map MF-1772, scale 1:24,000.

1234. Nuccio, V.F., and Johnson, R.C., 1981, Map showing drill stem test and perforation recoveries for the Upper Cretaceous Mesaverde Group, Piceance Creek basin, Colorado: U.S. Geological Survey Miscellaneous Field Studies Map MF-1359, scale 1:250,000.

1235. Nummedal, Dag, and Wright, Robyn, 1989, Cretaceous shelf sandstones and shelf depositional sequences, Western Interior Basin, Utah, Colorado, and New Mexico, in Hanshaw, P.M., ed., Sedimentation and basin analysis in siliciclastic rock sequences: Washington, D.C., American Geophysical Union, v. 1, 28th International Geological Congress Field Trip Guidebook $\mathrm{T} 119,87 \mathrm{p}$.

1236. Nutt, C.J., 1978, Drilling during 1977 in the Danforth Coal Field, Axial and Ninemile Gap Quadrangles, Moffat and Rio Blanco Counties, Colorado: U.S. Geological Survey Open-File Report 78-273, 17 p.

1237. Nutt, C.J., 1981, Geologic map and coal deposits of the western part of Ninemile Gap Quadrangle and the southern part of Axial Quadrangle, Moffat and Rio Blanco Counties, Colorado: U.S. Geological Survey Open-File Report $81-12,3$ sheets, scale $1: 24,000$.

1238. Nygren, W.E., 1935, An outline of the general geology and physiography of the Grand Valley district (Mesa County), Colorado: Boulder, University of Colorado, Master's thesis, $106 \mathrm{p}$. 
1239. O'Boyle, C.C., 1962, Surface mapping in northwestern Colorado, in Mott, M.R., and Amuedo, C.L., eds., Exploration for oil and gas in northwestern Colorado: Denver, Rocky Mountain Association of Geologists Guidebook, p. 45-48.

1240. O'Connor, T.E., 1961, The structure and stratigraphy of an area west of Taylor Park, northeast Gunnison County, Colorado: Boulder, University of Colorado, Master's thesis, 97 p.

1241. O'Hayre, A.P., Day, M.J., and Conn, Dennis, 1987, A semi-empirical method for predicting hydrologic impacts of underground mining in fracture-controlled groundwater flow systems, in Dworsky, R.F., ed., Proceedings of the Symposium on Water Resources Related to Mining and Energy--Preparing for the future, Utah, 1987: Urbana, I11., American Water Resources Association Technical Publication Series TPS-87-4, p. 247-257.

1242. O'Neill, J.M., 1981, Geologic map of the Mount Richthofen Quadrangle and the western part of the Fall River Pass Quadrangle, Grand and Jackson Counties, Colorado: U.S. Geological Survey Miscellaneous Investigations Series Map I-1291, scale 1:24,000.

1243. O'Sullivan, R.B., 1974, Preliminary geologic map of the Segar Mountain Quadrangle, Rio Blanco County, Colorado: U.S. Geological Survey Miscellaneous Field Studies Map MF-570, scale 1:24,000.

1244. O'Sullivan, R.B., 1975, Coughs Creek Tongue--A new tongue of the Eocene Green River Formation, Piceance Creek basin, Colorado: U.S. Geological Survey Bulletin 1395-G, 7 p.

1245. O'Sullivan, R.B., 1981, Stratigraphic sections of some Jurassic rocks from near Moab, Utah, to Slick Rock, Colorado: U.S. Geological Survey $0 i 1$ and Gas Investigations Chart OC-107.

1246. O'Sullivan, R.B., 1984, Stratigraphic sections of Middle Jurassic San Rafael Group and related rocks from Dewey Bridge, Utah, to Uravan, Colorado: U.S. Geological Survey $0 i l$ and Gas Investigations Chart OC-124.

1247. O'Sullivan, R.B., 1985, Preliminary geologic map of the Rio Blanco Quadrangle, Rio Blanco and Garfield Counties, Colorado: U.S. Geological Survey Miscellaneous Field Studies Map MF-1816, scale 1:24,000.

1248. O'Sullivan, R.B., 1986, Preliminary geologic map of the Anvil Points Quadrangle, Garfield County, Colorado: U.S. Geological Survey Miscellaneous Field Studies Map MF-1882, scale 1:24,000.

1249. O'Sullivan, R.B., 1986, Stratigraphic sections of Middle Jurassic San Rafael Group and related rocks from Uravan to Telluride in southwestern Colorado: U.S. Geological Survey Oil and Gas Investigations Chart OC-127.

1250. O'Sullivan, R.B., 1987, Chart showing correlation of selected parts of the Eocene Uinta and Green River Formations, southeastern Piceance Creek basin, Colorado: U.S. Geological. Survey Miscellaneous Field Studies Map MF-1986, scale not listed.

1251. O'Sullivan, R.B., 1987, Preliminary geologic map of the No-Name Ridge Quadrangle, Rio Blanco County, Colorado: U.S. Geological Survey Miscellaneous Field Studies Map MF-1989, scale 1:24,000.

1252. O'Sullivan, R.B., 1989, Stratigraphic sections of Middle Jurassic San Rafael Group and related rocks from Slick Rock to Uravan in southwestern Colorado: U.S. Geological Survey $0 i l$ and Gas Investigations Chart OC-133.

1253. O'Sullivan, R.B., and Hail, W.J., Jr., 1987, Preliminary geologic map of the Forked Gulch Quadrangle, Garfield County, Colorado: U.S. Geological Survey Miscellaneous Field Studies Map MF-1953, scale 1:24,000. 
1254. O'Sullivan, R.B., and Pipiringos, G.N., 1983, Stratigraphic sections of Middle Jurassic Entrada Sandstone and related rocks from Dewey Bridge, Utah, to Bridgeport, Colorado: U.S. Geological Survey Oil and Gas Investigations Chart OC-122.

1255. O'Sullivan, R.B., and Smith, M.C., 1985, Preliminary geologic map of the west half of the Thirteenmile Creek Quadrangle, Rio Blanco and Garfield Counties, Colorado: U.S. Geological Survey Miscellaneous Field Studies Map MF-1789, scale 1:24,000.

1256. 0'Sullivan, R.B., Wahl-Pierce, Frances, and Arbelbide, S.J., 1981, Preliminary geologic map of the McCarthy Gulch Quadrangle, Rio Blanco and Garfield Counties, Colorado: U.S. Geological Survey Miscellaneous Field Studies Map MF-0860, scale 1:24,000.

1257. Ode11, J.W., Coffin, D.L., and Langford, R.H., 1964, Water resources, in Mineral and water resources of Colorado: U.S. Congress, 88th, 2d session, U.S. Geological Survey Communication Print, p. 233-283.

1258. Olhoeft, G.R., and Scott, J.H., 1980, Nonlinear complex resistivity logging: Houston, Transactions of the Society of Professional Well Log Analysis Annual Logging Symposium 21, p. T1-T18.

1259. Olson, J.C., 1974, Geologic map of the Rudolph Hill Quadrangle, Gunnison, Hinsdale, and Saguache Counties, Colorado: U.S. Geological Survey Geologic Quadrangle Map GQ-1177, scale 1:24,000.

1260. 01son, J.C., 1976, Geologic map of the Iris Quadrangle, Gunnison and Saguache Counties, Colorado: U.S. Geological Survey Geologic Quadrangle Map GQ-1286, scale 1:24,000.

1261. Olson, J.C., 1976, Geologic map of the Houston Gulch Quadrangle, Gunnison and Saguache Counties, Colorado: U.S. Geological Survey Geologic Quadrangle Map GQ-1287, scale 1:24,000.

1262. Olson, J.C., 1977, Preliminary geologic map of part of the Pahlone Peak Quadrangle, Gunnison, Saguache, and Chaffee Counties, Colorado: U.S. Geological Survey Open-File Report 77-325, scale 1:24,000.

1263. 0lson, J.C., 1979, Preliminary geologic and structural maps and sections of the Marshall Pass mining district, Saguache, Gunnison, and Chaffee Counties, Colorado: U.S. Geological Survey Open-File Report 79-1473, scale not listed.

1264. Olson, J.C., and Hedlund, D.C., 1956, Field investigations, Gunnison County, Colorado: U.S. Geological Survey Trace Element Investigations Report TEI-640, p. 323-325.

1265. Olson, J.C., and Hedlund, D.C., 1973, Geologic map of the Gateview Quadrangle, Gunnison County, Colorado: U.S. Geological Survey Geologic Quadrangle Map GQ-1071, scale 1:24,000.

1266. Olson, J.C., Hedlund, D.C., and Hansen, W.R., 1968, Tertiary volcanic stratigraphy in the Powderhorn-Black Canyon region, Gunnison and Montrose Counties, Colorado: U.S. Geological Survey Bulletin 1251-C, p. C1-C29.

1267. Olson, J.C., and Steven, T.A., 1976, Geologic map of the Sawtooth Mountain Quadrangle, Saguache County, Colorado: U.S. Geological Survey Miscellaneous Field Studies Map MF-733, scale 1:24,000. (Reprinted.)

1268. Olson, J.C., and Steven, T.A., 1976, Geologic map of the Razor Creek Dome Quadrangle, Saguache County, Colorado: U.S. Geological Survey Miscellaneous Field Studies Map MF-748, scale 1:24,000. (Reprinted.)

1269. Olson, J.C., Steven, T.A., and Hedlund, D.C., 1975, Geologic map of the Spring Hill Creek Quadrangle, Saguache County, Colorado: U.S. Geological Survey Miscellaneous Field Studies Map MF-713, scale 1:24,000. (Reprinted.)

1270. Ormes, R.M., 1979, Guide to the Colorado mountains (7th ed.): Colorado Springs, Colo., 344 p. 
1271. Ortiz, N.V., Ferentchak, J.A., Ethridge, F.G., Granger, H.C., and Sunada, D.K., 1980, Ground-water flow and uranium in Colorado Plateau: Ground Water, v. 18, no. 6, p. 596-606.

1272. Osterwald, F.W., and Dean, B.A., comps., 1958, Preliminary tectonic map of northern Colorado and northeastern Utah, showing distribution of uranium deposits: U.S. Geological Survey Mineral Investigations Field Studies Map MF-130, 2 sheets, scale 1:500,000.

1273. Overton, H.L., 1978, Appraisal of water movement from subsurface data: Log Analyst, v. 19 , no. 5, p. 3-20.

1274. Owen, A.E., and Whitney, G.W., 1956, San Arroyo Bar-X area, Grand County, Utah, and Mesa County, Colorado, in Geology and economic deposits of east central Utah, Intermountain Association of Petroleum Geologists, 7th field conference, Salt Lake City, 1956, [Guidebook?], [Salt Lake City?], Intermountain Association of Petroleum Geologists, p. 195-198.

1275. Owen, T.E., and Suhler, S.A., 1980, Subsurface void detection using surface resistivity and borehole electromagnetic techniques: Houston, Society of Exploration Geophysicists Technical Paper 50, p. 3427-3448.

1276. Owens, W.G., 1970, Ground water and our environment, in Governor's Conference on Environmental Geology: Colorado Geological Survey Special Publication 1, p. 38-41.

1277. Page, L.R., Stocking, H.E., and Smith, H.B., comps., 1956, Contributions to the geology of uranium and thorium by the United States Geological

Survey and Atomic Energy Commission for the United Nations International Conference on Peaceful Uses of Atomic Energy, Geneva, Switzerland, 1955: U.S. Geological Survey Professional Paper 300, $739 \mathrm{p}$.

1278. Pantea, M.P., 1987, Preliminary geologic map of the Davis Canyon Quadrangle, Uintah County, Utah, and Garfield and Rio Blanco Counties, Colorado: U.S. Geological Survey Miscellaneous Field Studies Map MF-1933, scale 1:24,000.

1279. Parker, B.H., 1934, A review of the geology of Colorado with a contribution to orogeny: Golden, Colorado School of Mines, Ph.D. dissertation, $132 \mathrm{p}$.

1280. Parsons, M.C., 1954, Geology of the Gore Canyon area (Grand and Eagle Counties), Colorado: Golden, Colorado School of Mines, Master's thesis, $102 \mathrm{p}$.

1281. Patt, R.0., Adams, D.B., and Collins, D.L., 1982, Hydrologic data from Naval 0il Shale Reserves, Parachute Creek basin, northwestern Colorado, 1975-79: U.S. Geological Survey Open-File Report 82-696, 134 p.

1282. Patton, H.B., 1916, Geology and ore deposits of the Bonanza district, Saguache County: Colorado Geological Survey Bulletin 9, $136 \mathrm{p}$.

1283. Patton, H.B., 1917, Geology and ore deposits of the Platoro-Summitville mining district, Colorado: Colorado Geological Survey Bulletin 13, $122 \mathrm{p}$.

1284. Pawlewicz, M.J., 1984, Stratigraphy, environments of deposition and petrography of selected coals of the Upper Cretaceous Menefee Formation near Durango, Colorado: Golden, Colorado School of Mines, Master's thesis, $116 \mathrm{p}$.

1285. Peale, A.C., 1876, Report of Middle Division: U.S. Geological and Geographical Survey of the Territories (Hayden) Annual Report 8, p. $73-180$.

1286. Peale, A.C., 1878, Geological report on the Grand River district: U.S. Geological and Geographical Survey of the Territories (Hayden) Annual Report 10, p. 161-185.

1287. Pearl, R.H., 1971, Bibliography of hydrogeologic reports in Colorado: Colorado Geological Survey Bulletin 33, 39 p. 
1288. Pearl, R.H., 1974, Geology of ground-water resources in Colorado--An introduction: Colorado Geological Survey Special Publication 4, $47 \mathrm{p}$.

1289. Pearl, R.H., 1980, Ground-water resources of Colorado, in Kent, H.C., and Porter, K.W., eds., Colorado geology: Denver, Rocky Mountain Association of Geologists, p. 243-245.

1290. Pearl, R.H., 1981, Hydrothermal resources of western Colorado, in Epis, R.C., and Callender, J.F., eds., Western Slope, Colorado--Western Colorado and eastern Utah: [Socorro?], New Mexico Geological Society Guidebook 32, p. 333-335.

1291. Pearl, R.H., 1984, Dakota aquifer system in the State of Colorado, in Jorgensen, D.G., and Signor, D.C., eds., Geohydrology of the Dakota Aquifer--C.V. Theis Conference on Geohydrology, 1st, Lincoln, Nebr., Oct. 5-6, 1982, Proceedings: Worthington, Ohio, National Water Well Association, p. 41-47.

1292. Pearl, R.H., Zacharakis, T.G., Repplier, F.N., and others, 1981, Bibliography of geothermal reports in Colorado: Colorado Geological Survey Bulletin 44, $24 \mathrm{p}$.

1293. Pear1, R.H., Zacharakis, T.G., and Ringrose, C.D., 1982, Geothermal resource assessment of Hot Sulphur Springs, Colorado: Colorado Geological Survey Resource Series 23, 50 p.

1294. Pearl, R.H., Zacharakis, T.G., and Ringrose, C.D., 1983, Geothermal resource assessment of the Steamboat-Routt Hot Springs area, Colorado: Colorado Geological Survey Resource Series 22, 86 p.

1295. Pearl, R.M., 1939, Chalk Mountain, Colorado: Compass, v. 19, no. 2, p. $137-140$.

1296. Peck, C.J., 1985, Paleomagnetism and diagenesis of the Upper Cambrian Peerless Formation, central Colorado: Norman, University of Oklahoma, Master's thesis, $58 \mathrm{p}$.

1297. Peck, C.J., 1986, Paleozoic diagenesis of the Upper Cambrian Peerless Formation, Colorado: Shale Shaker, v. 36, no. 4, p. 209-213.

1298. Pennak, R.W., 1969, Colorado semidrainage mountain lakes: Limnology and Oceanography, v. 14, no. 5, p. 720-725.

1299. Perkins, R.M., 1975, Geology and mineral deposits of the Unaweep mining district, Mesa County, Colorado: Boulder, University of Colorado, Master's thesis, $53 \mathrm{p}$.

1300. Peterson, Fred, and Kirk, A.R., 1977, Correlation of the Cretaceous rocks in the San Juan, Black Mesa, Kaiparowits and Henry basins, southern Colorado Plateau, in Fassett, J.E., ed., Guidebook of San Juan basin III, northwestern New Mexico: [Socorro?], New Mexico Geological Society, 28 th field conference 1977, p. 167-178.

1301. Peterson, Fred, and Turner-Peterson, Christine, 1986, Recent advances in Morrison sedimentology on the Colorado Plateau [abs?]: North American Paleontological Convention, 4th, Boulder, Colo., Aug. 12-15, 1986, Proceedings, p. A35.

1302. Peterson, Fred, and Turner-Peterson, Christine, 1987, The Morrison Formation of the Colorado Plateau--Recent advances in sedimentology, stratigraphy, and paleotectonics: Hunteria, v. 2, no. 1, unknown pagination.

1303. Peterson, Fred, and Turner-Peterson, Christine, 1989, Sedimentation and Geology of the Colorado Plateau, in Hanshaw, P.M., ed., Sedimentation and basin analysis in siliciclastic rock sequences: Washington, D.C., American Geophysical Union, v. 1, 28th International Geological Congress Field Trip Guidebook 130, 65 p. 
1304. Peterson, Fred, and Tyler, Noel, 1985, Field trip 3--Field guide to the upper Salt Wash alluvial complex, in Flores, R.M., and Harvey, M., eds., Field guidebook to modern and ancient fluvial systems in the United States, International Fluvial Sedimentologists Conference, 3d, Fort Collins, Colo., 1985: Fort Collins, Colo., International Fluvial Sedimentologists Guidebook 3, p. 45-64.

1305. Peterson, J.A., 1955, Marine Jurassic rocks, northern and eastern Uinta Mountains, and adjacent areas [Colorado, Utah, Wyoming], in Green River basin, Wyoming Geological Association, 10th field conference, Guidebook: [Laramie?], Wyoming Geological Association p. 75-79.

1306. Peterson, J.A., Loleit, A.J., Spencer, C.W., and others, 1968, Sedimentary history and economic geology of San Juan basin, New Mexico and Colorado, in Galley, J.E., ed., Subsurface disposal in geologic basins--A study of reservoir strata: American Association of Petroleum Geologists Memoir 10, p. 186-231.

1307. Peterson, R.E., and Kohout, Julie, 1983, An approximation of continuity of lenticular Mesaverde Sandstone lenses utilizing close-well correlations, Piceance basin, northwestern Colorado, in Kersch, K.M., chairperson, Proceedings of the 1983 Society of Petroleum Engineers/Department of Energy joint symposium on low permeability gas reservoirs: [Dallas?], Society of Petroleum Engineers, p. 95-106.

1308. Phipps, J.B., 1961, Geology of the area north of New Castle (Garfield County), Colorado: Boulder, University of Colorado, Master's thesis, $62 \mathrm{p}$.

1309. Phoenix, D.A., 1953, Ground-water studies [Colorado Plateau]: U.S. Geological Survey Trace Element Investigations Report TEI-280, p. 23-24.

1310. Phoenix, D.A., 1956, Relation of carnotite deposits to permeable rocks in the Morrison Formation, Mesa County, Colorado, in Geology of uranium and thorium: United Nations International Conference on Peaceful Uses of Atomic Energy, Geneva, 1956, Switzerland, Proceedings, v. 6, p. 321-325.

1311. Phoenix, D.A., 1959, Occurrence and chemical character of ground water in the Morrison Formation, Colorado-Utah, in Garrels, R.M., and Larsen, E.S., comps., Geochemistry and mineralogy of the Colorado Plateau uranium ores: U.S. Geological Survey Professional Paper 320, part 4, p. 55-64.

1312. Phoenix, D.A., 1961, Proposed classification of ground-water provinces, hydrologic units, and chemical types of ground water in the Upper Colorado River Basin, in Short papers in the geologic and hydrologic sciences: U.S. Geological Survey Professional Paper 424-C, p. C125-C126.

1313. Phoenix, D.A., and Franks, P.C., 1956, Subsurface geologic investigations by drilling [Colorado Plateau]: U.S. Geological Survey Trace Element Investigations Report TEI-620, p. 89-92.

1314. Picard, M.D., 1977, Stratigraphic analysis of the Navajo Sandstone--A discussion: Journal of Sedimentary Petrology, v. 47, no. 1, p. 475-483.

1315. Pierson, C.T., 1953, San Juan Mountains, Colorado--Reconnaissance: U.S. Geological Survey Trace Elements Investigations Report TEI-330, p. 101.

1316. Pipiringos, G.N., and Johnson, R.C., 1975, Preliminary geologic map of the Buckskin Point Quadrangle, Rio Blanco County, Colorado: U.S.

Geological Survey Miscellaneous Field Studies Map MF-651, scale 1:24,000.

1317. Pipiringos, G.N., and Johnson, R.C., 1976, Preliminary geologic map and correlation diagram of the White River City Quadrangle, Rio Blanco County, Colorado: U.S. Geological Survey Miscellaneous Field Studies Map MF-736, scale $1: 24,000$. (Reprinted.) 
1318. Pipiringos, G.N., and Rosenlund, G.C., 1977, Preliminary geologic map of the Indian Valley Quadrangle, Rio Blanco and Moffat Counties, Colorado: U.S. Geological Survey Miscellaneous Field Studies Map MF-836, scale $1: 24,000$. (Reprinted.)

1319. Pipiringos, G.N., and Rosenlund, G.C., 1977, Preliminary geologic map of the White Rock Quadrangle, Rio Blanco and Moffat Counties, Colorado: U.S. Geological Survey Miscellaneous Field Studies Map MF-837, scale $1: 24,000$.

1320. Pisarowicz, J.A., and Maslyn, R.M., 1981, Empirical confirmation of Curl's (1974) flow velocity calculations, in Beck, B.F., ed., Proceedings of the Eighth International Congress of Speleology: International Congress of Speleology Proceedings 8, p. 772-774.

1321. Pitman, J.K., 1979, Isopach, structure contour, and resource maps of the R-6 oil-shale zone, Green River Formation, Piceance Creek basin, Colorado: U.S. Geological Survey Miscellaneous Field Studies Map MF-1069, 2 sheets, scale $1: 126,720$.

1322. Pitman, J.K., 1982, Regional stratigraphic and depositional analysis of rock units in the upper Garden Gulch and Parachute Creek Members of the Green River Formation, Piceance Creek basin, Colorado, in Gary, J.H., ed., Fifteenth Oil Shale Symposium Proceedings: Golden, Colorado School of Mines Press, p. 79-100.

1323. Pitman, J.K., and Johnson, R.C., 1978, Isopach, structure contour, and resource maps of the Mahogany oil-shale zone, Green River Formation, Piceance Creek basin, Colorado: U.S. Geological Survey Miscellaneous Field Studies Map MF-958, 2 sheets, scale 1:126,720.

1324. Poelchau, H.S., 1963, Geology of the Gore Creek area, Eagle County, Colorado: Boulder, University of Colorado, Master's thesis, $76 \mathrm{p}$.

1325. Poet, S.E., 1932, The story of Tin Cup, Colorado: Colorado Magazine, v. 9 , p. 30-38.

1326. Poole, F.G., 1954, Geology of the southern Grand Hogback area, Garfield and Pitkin Counties: Boulder, University of Colorado, Master's thesis, $128 \mathrm{p}$.

1327. Powell, J.W., 1875, Exploration of the Colorado River of the west and its tributaries: Washington, D.C., U.S. Government Printing Office, $291 \mathrm{p}$.

1328. Powell, J.W., 1876, Report of the geology of the eastern portion of the Uinta Mountains and a region of country adjacent thereto: U.S.

Geological and Geographical Survey of the Territories, Powell Survey, Final Report 7, $218 \mathrm{p}$.

1329. Powel1, W.J., 1954, Ground water at Towaoc, Colorado: U.S. Geological Survey Open-File Report, unknown pagination.

1330. Praetorius, H.W., 1956, Stratigraphy of the Permian Phosphoria Formation of northwestern Colorado (Moffat County) and northeastern Utah: Boulder, University of Colorado, Master's thesis, 96 p.

1331. Prather, T.L., 1961, Geology of the north Italian Mountain area, Gunnison County, Colorado: Boulder, University of Colorado, Master's thesis, $76 \mathrm{p}$.

1332. Prather, T.L., 1964, Stratigraphy and structural geology of the E1k Mountains (Pitkin and Gunnison Counties), Colorado: Boulder, University of Colorado, Ph.D. dissertation, $106 \mathrm{p}$.

1333. Pratt, W.P., 1968, Summary of the geology of the Rico region, Colorado, in New Mexico Geological Society, and Shoemaker, J.W., eds., Guidebook of San Juan-San Miguel-La Plata region, New Mexico and Colorado, 19th field conference, 1968: Socorro, New Mexico Bureau of Mines and Mineral

Resources, p. 83-87. 
1334. Pratt, W.P., 1976, Preliminary geologic map of the Hermosa Peak Quadrangle, Dolores, San Juan, La Plata, and Montezuma Counties, Colorado: U.S. Geological Survey Open-File Report 76-314, scale $1: 20,000$.

1335. Pratt, W.P., McKnight, E.T., and DeHon, R.A., 1969, Geologic map of the Rico Quadrangles, Dolores and Montezuma Counties, Colorado: U.S. Geological Survey Geologic Quadrangle Map GQ-797, scale 1:24,000.

1336. Presser, T.S., Evans, W.C., White, L.D., and Barnes, Ivan, 1981, Chemical and isotopic compositions of selected soda and hot spring waters, Colorado: U.S. Geological Survey Open-File Report 81-684, 9 p. [Available from U.S. Geological Survey, Water Resources Division, 345 Middlefield Road, Mail Stop 34, Menlo Park, CA 94025.]

1337. Price, Don, 1989, Northern Great Plains and Rocky Mountain provinces-Uinta and southwestern Utah regions, in Britton, L.J., Anderson, C.L., Goolsby, D.A., and Van Haveren, B.P., eds., Summary of the U.S. Geological Survey and U.S. Bureau of Land. Management national coal-hydrology program, 1974-84: U.S. Geological Survey Professional Paper 1464, p. 95-102.

1338. Price, Don, and Arnow, Ted, 1974, Summary appraisals of the Nation's ground-water resources--Upper Colorado region: U.S. Geological Survey Professional Paper 813-C, 40 p. (Reprinted in 1976.)

1339. Price, Don, and Miller, L.L., 1975, Hydrologic reconnaissance of the southern Uinta Basin, Utah and Colorado: Utah Department of Natural Resources Technical Publication 49, $66 \mathrm{p}$.

1340. Price, Don, and Waddel1, K.M., 1973, Selected hydrologic data in the Upper Colorado River Basin: U.S. Geological Survey Hydrologic Investigations Atlas $\mathrm{HA}-477,2$ sheets, scale $1: 2,500,000$.

1341. Price, J.B., 1986, Application of a mixing cell model to describe contaminant transport--An example of appropriate technology, in Abt, S.R., Nelson, J.D., Shepherd, T.A., Wardwell, R.E., and van Zyl, Dirk, eds., Proceedings of the 8th Annual Symposium on Geotechnical and Geohydrological Aspects of Waste Management, Fort Collins, Colo., Feb. 5-7, 1986: Rotterdam, A.A. Balkema, p. 197-203.

1342. Price, J.B., 1986, Implications of an assessment of potential organic contamination of ground water at an inactive uranium mill, in Abt, S.R., Nelson, J.D., Shepherd, T.A., Wardwell, R.E., and van Zyl, Dirk, eds., Proceedings of the 8th Annual Symposium on Geotechnical and Geohydrological Aspects of Waste Management, Fort Collins, Colo., Feb. 5-7, 1986: Rotterdam, A.A. Balkema, p. 247-252.

1343. Price, J.N., 1976, Geology for [land-use] planning in eastern Middle Park, Grand County, Colorado: Fort Collins, Colorado State University, Master's thesis, $152 \mathrm{p}$.

1344. Price, J.N., 1978, Geology for land-use planning in the Craig area, Moffat County, Colorado: Colorado Geological Survey Map Series 7, 2 sheets, scale $1: 12,700$.

1345. Price, J.N., 1980, Geology for land-use planning in the Green Mountain Reservoir area, Summit County, Colorado: Colorado Geological Survey Open-File Report 80-6, scale 1:24,000.

1346. Prichard, G.E., 1955, Washakie basin, Wyoming and Colorado; Baggs area, Carbon and Sweetwater Counties, Wyoming, and Moffat County, Colorado:

U.S. Geological Survey Trace Element Investigations Report TEI-590, p. $174-176$.

1347. Prichard, G.E., 1956, Baggs area, Carbon and Sweetwater Counties, Wyoming, and Moffat County, Colorado: U.S. Geological Survey Trace Element Investigations Report TEI-620, p. 188-190. 
1348. Prommel, H.W.C., 1937, Pennsylvanian basin of west-central Colorado geologized: 0il and Gas Journal, v. 36, no. 19, p. 20-21, 24.

1349. Prost, Gary, 1977, Reconnaissance drilling in the Yampa Coal Field, Hayden-Williams Fork Mountains area (Yampa No. 3), Moffat and Routt Counties, Colorado, during 1976: U.S. Geological Survey Open-File Report 77-155, 7 p.

1350. Purington, C.W., 1899, Economic geology of the La Plata Quadrangle, Colorado, in Cross, C.W., Spencer, A.C., and Purington, C.W., Description of the La Plata Quadrangle, Colorado: U.S. Geological Survey Geologic Atlas of the United States, Folio 60, p. 12-14.

1351. Purington, C.W., 1908, Treasure Mountain, Colorado: Mining and Scientific Press, v. 97, p. 23-25.

1352. Radabaugh, R.E., Merchant, J.S., and Brown, J.M., 1968, Geology and ore deposits of the Gilman (Red Cliff, Battle Mountain) district, Eagle County, Colorado, in Ore deposits of the United States, 1933-1967 [Graton-Sales Volume], v. 1: New York, American Institute of Mining, Metallurgical, and Petroleum Engineers, p. 641-664.

1353. Raines, G.L., 1971, Geology of the Sargents area, Gunnison and Saguache Counties, Colorado: Golden, Colorado School of Mines, Master's thesis, $55 \mathrm{p}$.

1354. Raleigh, C.B., 1972, Earthquakes and fluid injection, in Cook, T.D., Underground waste management and environmental implications: American Association of Petroleum Geologists Memoir 18, p. 273-279.

1355. Randall, J.A., 1958, The geology and ore deposits of Upper Mayflower Gulch, Summit County, Colorado: Boulder, University of Colorado, Master's thesis, $37 \mathrm{p}$.

1356. Randolph, P.L., 1983, Porosity and permeability of Mesaverde Sandstone core from the U.S. D.O.E. Multiwell Experiment, Garfield County, Colorado, in Kersch, K.M., chairperson, Proceedings of the 1983 Society of Petroleum Engineers/Department of Energy joint symposium on low permeability gas reservoirs: [Dallas?], Society of Petroleum Engineers, p. 449-460.

1357. Ransome, F.L., 1901, A report on the economic geology of the Silverton Quadrangle, Colorado: U.S. Geological Survey Bulletin 182, 265 p.

1358. Ransome, F.L., 1905, Economic geology of the Silverton Quadrangle, Colorado, in Cross, C.W., Howe, Ernest, and Ransome, F.L., Description of the Silverton Quadrangle, Colorado: U.S. Geological Survey Geologic Atlas of the United States, Folio 120, p. 26-34.

1359. Ransome, F.L., 1911, Geology and ore deposits of the Breckenridge district, Colorado: U.S. Geological Survey Professional Paper 75, 187 p.

1360. Ranspot, H.W., 1958, Geology and uranium deposits of the Indian Creek area, Gunnison and Saguache Counties, Colorado: Boulder, University of Colorado, Master's thesis, $57 \mathrm{p}$.

1361. Rath, Gerhard vom, 1885, Wahrnehmungen in der umgebung von Silver Cliff, Salida, Leadville, und Gunnison, Colorado [Observations in the area of Silver Cliff, Salida, Leadville, and Gunnison, Colorado]: Naturhistorischer Verein der Preussischen Rheinlande und Westphalens, Verhandlungen, v. 42, p. 92-134.

1362. Read, C.B., Wood, G.H., Wanek, A.A., and Mackee, P.V., 1949, Stratigraphy and geologic structure in the Piedra River Canyon, Archuleta County, Colorado: U.S. Geological Survey Oil and Gas Investigations Map OM-96, scale $1: 48,000$.

1363. Read, T.T., 1907, The great San Juan: Mines and Minerals, v. 14, no. 22, p. 8 . 
1364. Readdy, L.A., and Pentz, D.L., 1977, U.S.B.M. pilot hole "X", Horse Draw, Rio Blanco County, Colorado--Section 1, Volume 1, Geology and geophysics: U.S. Bureau of Mines Report 103(1)-77, 44 p.

1365. Reagan, A.B, 1921, Glacial deposits in Pine River valley, Colorado: Indianapolis, Indiana Academy of Science Proceedings, p. 353-354.

1366. Reagan, A.B., 1922, Glacial deposits in Pine River valley, Colorado: Lawrence, Kansas Academy of Science Transactions, v. 30, p. 129-130.

1367. Reeside, J.B., Jr., 1955, Revised interpretation of the Cretaceous section on Vermilion Creek, Moffat County, Colorado, in Green River basin: [Laramie?], Wyoming Geological Association Guidebook 10, p. 85-88.

1368. Reheis, M.C., 1980, Geologic map and coal sections of the Thornburgh Quadrangle, Moffat and Rio Blanco Counties, Colorado: U.S. Geological Survey Open-File Report 80-251, 2 sheets, scale 1:24,000.

1369. Reheis, M.C., 1980, Geologic map and coal sections of the Sawmill Mountain Quadrangle, Rio Blanco County, Colorado: U.S. Geological Survey Open-File Report 80-252, 2 sheets, scale 1:24,000.

1370. Reheis, M.C., 1981, Geologic map and coal resources of the Easton Gulch Quadrangle, Moffat County, Colorado: U.S. Geological Survey Coal Investigations Map C-87, scale 1:24,000.

1371. Reheis, M.C., 1984, Geologic map and coal sections of the Sawmill Mountain Quadrangle, Rio Blanco County, Colorado: U.S. Geological Survey Coal Investigations Map C-99, scale 1:24,000.

1372. Reheis, M.C., 1984, Geologic map and coal sections of the Thornburgh Quadrangle, Moffat and Rio Blanco Counties, Colorado: U.S. Geological Survey Coal Investigations Map C-100, scale 1:24,000.

1373. Reheis, M.J., 1976, Reconniassance drilling in the Danforth Hills Coal Field, Moffat and Rio Blanco Counties, Colorado, August-September 1976: U.S. Geological Survey Open-File Report 76-870, 74 leaves.

1374. Reheis, M.J., 1978, Drilling during 1977 in the Danforth Hills Coal Field, Easton Gulch and Devils Hole Gulch Quadrangles, Moffat County, Colorado: U.S. Geological Survey Open-File Report 78-272, 29 p.

1375. Reheis, M.J., 1978, Drilling during 1978 in the Danforth Hills Coal Field, Easton Gulch, Devils Hole Gulch, Axial, and Ninemile Gap Quadrangles, Moffat and Rio Blanco Counties, Colorado: U.S. Geological Survey Open-File Report 78-1031, 38 p.

1376. Reheis, M.J., and Peterson, J.E., 1977, Reconnaissance drilling in the Danforth Hills Coal Field, Moffat and Rio Blanco Counties, Colorado, September-October 1976: U.S. Geological Survey Open-File Report 77-42, $67 \mathrm{p}$.

1377. Reiter, Marshall, and Clarkson, Gerry, 1983, Geothermal studies in the San Juan basin and the Four Corners area of the Colorado Plateau--II, Steady-state models of the thermal source of the San Juan volcanic field: Tectonophysics, v. 91, nos. 3-4, p. 253-269.

1378. Reiter, Marsha11, and Mansure, A.J., 1983, Geothermal studies in the San Juan basin and the Four Corners area of the Colorado Plateau--I, Terrestrial heat-flow measurements: Tectonophysics, v. 91, nos. 3-4, p. 233-251.

1379. Repplier, F.N., Healy, F.C., Collins, D.B., and others, 1981, Atlas of ground water quality in Colorado: Colorado Geological Survey Map Series 16, 7 sheets, scale 1:500,000.

1380. Rettew, D.M., 1978, Paleoenvironmental study of the Chaffee Group (Upper Devonian) in northeast Gunnison County, Colorado: Lexington, University of Kentucky, Master's thesis, 85 p. 
1381. Retzer, J.L., 1954, Glacial advances and soil development, Grand Mesa, Colorado: American Journal of Science, v. 252, no. 1, p. 26-37.

1382. Rhodes, F.H., and Fisher, J.H., 1957, Ignacio quartzite of southwestern Colorado: American Association of Petroleum Geologists Bulletin, v. 41, no. 11, p. 2508-2518.

1383. Rice, R.S., and Reimer, G.M., 1977, Helium analysis of subsurface waters as a uranium exploration tool, in Symposium on Hydrogeochemical and Stream-Sediment Reconnaissance for Uranium in the United States: U.S. Department of Energy Report GJBX-77-77, p. 301-302.

1384. Richards, Arthur, 1941, Geology of the Kremmling area, Grand County, Colorado: Ann Arbor, University of Michigan, Ph.D. dissertation, unknown pagination.

1385. Richmond, G.M., 1986, Stratigraphy and correlation of glacial deposits of the Rocky Mountains, the Colorado Plateau and the ranges of the Great Basin, in Sibrava, Vladimir, Bowen, D.Q., and Richmond, G.M., eds., Quaternary glaciations in the northern hemisphere: Paris, France, United Nations Educational, Scientific, and Cultural Organization (UNESCO), Earth Science Division, Quaternary Science Reviews 5, p. 99-127.

1386. Ridgley, J.L., 1984, Paleogeography and facies distribution of the Todilto Limestone and Pony Express Limestone Member of the Wanakah Formation, Colorado and New Mexico [abs.]: Geological Society of America, Abstracts with Programs, v. 16, no. 4, p. 252.

1387. Ridlon, J.B., 1954, Stratigraphy and paleontology of the Belden Formation (Pennsylvanian) in part of west-central Colorado, Pitkin and Eagle Counties: Boulder, University of Colorado, Master's thesis, $140 \mathrm{p}$. 1388. Rigby, J.K., 1976, Field guide--Northern Colorado Plateau: Dubuque, Iowa, Kendall/Hunt Publishing Company, 207 p.

1389. Riley, P.E., 1950, Geology of an area along the Colorado River, T. 3 S., R. 85 W., Eagle County, Colorado: Boulder, University of Colorado, Master's thesis, $24 \mathrm{p}$.

1390. Riley, R.G., Garland, T.R., Shiosaki, K., Mann, D.C., and Wildung, R.E., 1981, Alkylpyridines in surface waters, groundwaters, and subsoils of a drainage located adjacent to an oil shale facility: Environmental Science and Technology, v. 15, no. 6, p. 697-701.

1391. Rima, D.R., Chase, E.B., and Myers, B.M., 1971, Subsurface waste disposal by means of wells--A selective annotated bibliography: U.S. Geological Survey Water-Supply Paper 2020, 305 p.

1392. Ritzma, H.R., 1956, Structural development of the eastern Uinta Mountains and vicinity, Colorado, Utah, and Wyoming, in Geological record, February 1956: [Denver?], American Association of Petroleum Geologists, Rocky Mountain Section, p. 119-128.

1393. Ritzma, H.R., 1965, Geologic significance, No. 1 Raeder-Gov't, Dry Mountain Anticline, Moffat County, Colorado, in Sedimentation of Late Cretaceous and Tertiary outcrops, Rock Springs uplift--Wyoming Geological Association, 19th field conference, 1965, Guidebook: Casper, Wyo., Petroleum Information, p. 131-135.

1394. Ritzma, H.R., 1965, Piceance Creek Sandstone, basal Green River Sandstone tongue, northeast Piceance Creek basin, Colorado: Mountain Geologist, v. 2, no. 3, p. 103-107.

1395. Ritzma, H.R., 1987, Basement in the Uintas--An enigma? [abs.?]: American Association of Petroleum Geologists Bulletin, v. 71, no. 8, p. 1014 . 
1396. Ritzma, H.R., and Oriel, S.S., eds., 1955, Guidebook to the geology of northwest Colorado, Intermountain Association of Petroleum Geologists, 6 th annual field conference, and Rocky Mountain Association of Geologists annual field conference, 1955: Salt Lake City, Intermountain Association of Petroleum Geologists, $185 \mathrm{p}$.

1397. Rizo, J.A., 1971, Geology of the Gypsum-Dotsero area, Eagle County, Colorado: Golden, Colorado School of Mines, Master's thesis, 94 p.

1400. Robinette, M., and Williams, R.E., 1979, Delineation of hydrostratigraphic units using borehole geophysical techniques: Proceedings of the Symposium--Uranium Mill Tailings Management 2, p. 3-12.

1401. Robinson, C.H., and Dea, P.A., 1981, Quaternary glacial and slopefailure deposits of the Crested Butte area, Gunnison County, Colorado, in Epis, R.C., and Callender, J.F., eds., Western Slope, Colorado-Western Colorado and eastern Utah: [Socorro?], New Mexico Geological Society Guidebook 32, p. 155-163.

1402. Robinson, C.S., Gallant, W.A., and Cochran, D.M., 1976, Land use and engineering geology of the Front Range, Colorado, in Epis, R.C., ed., Studies in Colorado field geology: Professional Contributions of Colorado School of Mines 8, p. 486-504.

1403. Robinson, C.S., Warner, L.A., and Wahlstrom, E.E., 1974, General geology of the Harold D. Roberts Tunnel, Colorado: U.S. Geological Survey Professional Paper 831-B, 48 p.

1404. Robson, S.G., and Saulnier, G.J., Jr., 1980, Hydrogeochemistry and simulated solute transport, Piceance basin, northwestern Colorado: U.S. Geological Survey Open-File Report 80-72, 95 p.

1405. Robson, S.G., and Saulnier, G.J., Jr., 1981, Hydrogeochemistry and simulated solute transport, Piceance basin, northwestern Colorado: U.S. Geological Survey Professional Paper 1196, 65 p.

1407. Roche, W.M., and Steele, W.J., 1986, Colorado high mountain aquifer study, in Karamouz, Mohammad, Baumli, G.R., and Brick, W.J., eds., Water Forum '86--World water issues in evolution, in two volumes, Long Beach, Calif., Aug. 4-6, 1986: New York, American Society of Civil Engineers, p. 1413-1419.

1408. Rocky Mountain Association of Geologists, 1947, Guidebook of field conference in central Colorado, June 16, 17, 18, and 19, 1947: Denver, Rocky Mountain Association of Geologists, $74 \mathrm{p}$.

1409. Rocky Mountain Association of Geologists, 1953, Guidebook, of field conference in northwestern Colorado, May 14-16, 1953: Denver, Rocky Mountain Association of Geologists, $28 \mathrm{p}$.

1411. Roehler, H.W., 1972, Geologic map of the Red Creek Ranch Quadrangle, Wyoming, Utah, and Colorado: U.S. Geological Survey Geologic Quadrangle Map GQ-1001, scale 1:24,000.

1412. Roehler, H.W., 1972, Geologic map of the Four J Rim Quadrangle, Sweetwater County, Wyoming, and Moffat County, Colorado: U.S. Geological Survey Geologic Quadrangle Map GQ-1002, scale 1:24,000.

1413. Roehler, H.W., 1972, Geologic map of the Brushy Point Quadrangle, Rio Blanco and Garfield Counties, Colorado: U.S. Geological Survey Geologic Quadrangle Map GQ-1018, scale 1:24,000.

1414. Roehler, H.W., 1972, Geologic map of the Razorback Ridge Quadrangle, Rio Blanco and Garfield Counties, Colorado: U.S. Geological Survey Geologic Quadrangle Map GQ-1019, scale 1:24,000.

1415. Roehler, H.W., 1973, Geologic map of the Calf Canyon Quadrangle, Garfield County, Colorado: U.S. Geological Survey Geologic Quadrangle Map GQ-1086, scale 1:24,000. 
1416. Roehler, H.W., 1973, Geologic map of the Henderson Ridge Quadrangle, Garfield County, Colorado: U.S. Geological Survey Geologic Quadrangle Map GQ-1113, scale 1:24,000.

1417. Roehler, H.W., 1974, Geologic map of the Scrivner Butte Quadrangle, Sweetwater County, Wyoming, and Moffat County, Colorado: U.S. Geological Survey Geologic Quadrangle Map GQ-1166, scale 1:24,000.

1418. Roehler, H.W., 1978, Geologic map of the Chicken Creek SW Quadrangle, Sweetwater County, Wyoming, and Moffat County, Colorado: U.S. Geological Survey Geologic Quadrangle Map GQ-1443, scale 1:24,000.

1419. Roehler, H.W., 1985, Geologic map of the Kinney Rim 30 by 60-Minute Quadrangle, Wyoming and Colorado: U.S. Geological Survey Miscellaneous Investigations Series Map I-1615, scale 1:100,000.

1420. Roehler, H.W., 1987, Surface-subsurface correlations of the Mesaverde Group and associated Upper Cretaceous formations, Rock Springs, Wyoming, to Mount Harris, Colorado: U.S. Geological Survey Miscellaneous Field Studies Map MF-1937, scale not listed.

1421. Roehler, H.W., 1989, Correlation of surface sections of the intertongued Eocene Wasatch and Green River Formations across the central part of the Sand Wash basin, northwest Colorado, and eastern part of the Washakie basin, southwest Wyoming: U.S. Geological Survey Miscellaneous Field Studies Map MF-2106, scale about 1:253,440; vertical scale about 1:1,200.

1422. Roehler, H.W., 1989, Correlation of surface sections of the intertongued Eocene Wasatch and Green River Formations along the western margins of the Sand Wash basin, northwest Colorado, and Washakie basin, southwest Wyoming: U.S. Geological Survey Miscellaneous Field Studies Map MF-2105, scale about 1:253,440; vertical scale about $1: 1,200$.

1423. Roehler, H.W., and Hansen, D.E., 1989, Surface and subsurface correlations showing depositional environments of the Upper Cretaceous Mesaverde Group and associated formations, Cow Creek in southwest Wyoming to Mount Harris in northwest Colorado: U.S. Geological Survey Miscellaneous Field Studies Map MF-2077, vertical scale about 1:2,400.

1424. Rogers, W.P., and Rold, J.W., 1972, Engineering geologic factors of the Marble area, Gunnison County, Colorado: Colorado Geological Survey, $44 \mathrm{p}$.

1425. Ross, R.J., Jr., 1986, Lower Paleozoic of northwest Colorado--A summary, in Stone, D.S., and Johnson, K.S., eds., New interpretations of northwest Colorado geology: Denver, Rocky Mountain Association of Geologists Guidebook, p. 99-102.

1426. Rought, B.G., 1984, Southwestern salinity situation--The Rockies to the Mississippi, in French, R.H., ed., Salinity in watercourses and reservoirs--International Symposium on State-of-the-Art Control of Salinity, Salt Lake City, July 13-15, 1983, Proceedings: Boston, Butterworth Publishers, p. 115-124.

1427. Rowe, R.C., 1974, Geology of our western national parks and monuments: Portland, Ore., Binfords \& Mort, 220 p.

1428. Rowley, P.D., Dyni, J.R., Hansen, W.R., and Pipiringos, G.N., 1979, Geologic map of the Indian Water Canyon Quadrangle, Moffat County, Colorado: U.S. Geological Survey Geologic Quadrangle Map GQ-1516, scale $1: 24,000$.

1429. Rowley, P.D., and Hansen, W.R., 1979, Geologic map of the Plug Hat Rock Quadrangle, Moffat County, Colorado: U.S. Geological Survey Geologic Quadrangle Map GQ-1514, scale 1:24,000. 
1430. Rowley, P.D., Hansen, W.R., Tweto, Ogden, and Carrara, P.E., 1985, Geologic map of the Vernal $1^{\circ}$ by $2^{\circ}$ Quadrangle, Colorado, Utah, and Wyoming: U.S. Geological Survey Miscellaneous Investigations Series Map I-1526, scale $1: 250,000$.

1431. Rowley, P.D., Tweto, Ogden, Hansen, W.R., and Carrara, P.E., 1979, Geologic map of the Vernal $1^{\circ}$ by $2^{\circ}$ Quadrangle, Colorado, Utah, and Wyoming: U.S. Geological Survey Miscellaneous Field Studies Map MF-1163, scale $1: 250,000$. (Reprinted.)

1432. Roybal, F.E., 1989, Northern Great Plains and Rocky Mountain provinces-San Juan River region, in Britton, L.J., Anderson, C.L., Goolsby, D.A., and Van Haveren, B.P., eds., Summary of the U.S. Geological Survey and U.S. Bureau of Land Management national coal-hydrology program, 1974-84:

U.S. Geological Survey Professional Paper 1464, p. 111-117.

1433. Ruddy, B.C., 1989, Use of a hydraulic potentiomanometer to determine ground-water gradients in a wetland, Colorado, in Fisk, D.W., ed., Proceedings of the Symposium on Wetlands--Concerns and Successes, Tampa, Fla., Sept. 17-22, 1989: Urbana, I11., American Water Resources Association Technical Publication Series, TPS-89-3, p. 175-183.

1434. Ruffner, E.H., 1874, Report of reconnaissance in the Ute country, made in 1873: Washington, D.C., U.S. Congress, 43d, 1st Session, House Executive Document 193.

1435. Rugg, E.S., 1956, Geology of the Carter Mine, Gunnison County, Colorado: Golden, Colorado School of Mines, Master's thesis, $54 \mathrm{p}$.

1436. Rutherford, D.W., 1979, A geochemical baseline survey of selected toxic elements in surficial materials in the vicinity of the Paraho demonstration oil shale processing plant, Anvil Points, Garfield County, Colorado: Golden, Colorado School of Mines, Master's thesis, $153 \mathrm{p}$.

1437. Ryer, T.A., 1977, Geology and coal resources of the Foidel Creek EMRIA site and surrounding area, Routt County, Colorado: U.S. Geological Survey Open-File Report 77-303, 31 p.

1438. Sadlick, Walter, 1955, Carboniferous formations of northeastern Uinta Mountains, in Green River basin: [Laramie?], Wyoming Geological Association Guidebook, no. 10, p. 49-59.

1439. Samsela, J.J., Jr., 1980, Sedimentology of the Leadville Limestone (Mississippian) and the Chaffee Group (Upper Devonian), Chaffee, Fremont, and Saguache Counties, Colorado: Golden, Colorado School of Mines, Master's thesis, $168 \mathrm{p}$.

1440. Sanborn, A.F., ed., 1958, Guidebook to the geology of the Paradox basin: Salt Lake City, Intermountain Association of Petroleum Geologists, 9th annual field conference, 308 p.

1441. Sandberg, D.T., 1986, Isopach map of interval between top of the Pictured Cliffs Sandstone and the Huerfanito Bentonite bed of the Lewis Shale, La Plata County, Colorado, and Rio Arriba and San Juan Counties, New Mexico: U.S. Geological Survey Miscellaneous Field Studies Map MF-1831, 2 sheets, scale $1: 100,000$.

1442. Sanders, R.J., 1957, Geology of the Granby Anticline, in Finch, W.C., ed., Guidebook to the geology of North and Middle Parks basin, Colorado: Denver, Rocky Mountain Association of Geologists, p. 67-69.

1443. Saptarshi, V.C., 1946, Geology of the south flank of the Wildwood Anticline near Dillon, Summit County, Colorado: Golden, Colorado School of Mines, Master's thesis, $39 \mathrm{p}$.

1444. Saulnier, G.J., Jr., 1978, Genesis of the saline waters of the Green River Formation, Piceance basin, northwestern Colorado: Reno, University of Nevada, Ph.D. dissertation, 130 p. 
1445. Saulnier, G.J., Jr., and Goddard, K.E., 1982, Use of mathematical models to predict impacts of mining energy minerals on the hydrologic system in northwestern Colorado: Mining Engineering, v. 34, no. 3, p. 285-293.

1446. Saunders, G.P., 1983, Aquifer dewatering and drawdown at an open mine pit in northwestern Colorado, in National Water Well Association, ed., Proceedings of the symposium on practical ground-water monitoring considerations for the mining industry: National Water Well Association Ground Water Monitoring Review, v. 3, no. 1, p. 122-127.

1447. Sche11, E.M., and Yochelson, E.L., 1966, Permian-Triassic boundary in eastern Uintah County, Utah, and western Moffat County, Colorado, in Geological Survey research 1966: U.S. Geological Survey Professional Paper 550-D, p. D64-D68.

1448. Schenk, C.J., 1987, Sedimentology of an eolian sandstone from the Middle Pennsylvanian Eagle Valley Evaporite, Eagle basin, northwest Colorado, in Johnson, S.Y., Schenk, C.J., and Nuccio, V.F., Evolution of sedimentary basins--Uinta and Piceance basins: U.S. Geological Survey Bulletin 1787 A-C, p. 19-28.

1449. Schenk, C.J., 1989, Sedimentology and stratigraphy of the Eagle Valley Evaporite (Middle Pennsylvanian), Eagle basin, northwest Colorado: Boulder, University of Colorado, Ph.D. dissertation, $191 \mathrm{p}$.

1450. Schenk, C.J., Johnson, S.Y., and Karachewski, J.A., 1987, Field guide and road log--Pennsylvanian and Permian depositional systems and cycles in the Eagle basin, northwestern Colorado: U.S. Geological Survey Open-File Report 87-430, 29 p.

1451. Schenk, C.J., and Lockley, M.G., 1987, Middle Pennsylvanian paleogeography of the Eagle basin, northwest Colorado [abs.]: Geological Society of America, Abstracts with Programs, v. 19, no. 5, p. 331.

1452. Schlight, H.N., 1984, Structural geology and stratigraphy of the Jack's Cabin cutoff area, Gunnison County, Colorado [abs.]: Geological Society of America, Abstracts with Programs, v. 16, no. 4, p. 253.

1453. Schmidt, P.B., 1961, Geology of the State Bridge area (Eagle County), Colorado: Boulder, University of Colorado, Master's thesis, $67 \mathrm{p}$.

1454. Schmitt, L.J., and Raymond, W.H., 1977, Geology and mineral deposits of the Needle Mountains district, southwestern Colorado: U.S. Geological Survey Bulletin 1434, 40 p.

1455. Schneider, E.J., 1975, Surficial geology of the Grand Junction-Fruita area, Mesa County, Colorado: Fort Collins, Colorado State University, Master's thesis, $141 \mathrm{p}$.

1456. Schoenwetter, James, and Eddy, F.W., 1964, Alluvial and palynological reconstruction of environments, Navajo Reservoir district: Museum of New Mexico Papers on Anthropology 13, 155 p.

1457. Schroeder, D.A., 1987, Precambrian geology of the Granby and Strawberry Lake 7.5-Minute Quadrangles, Colorado [abs.]: Geological Society of America, Abstracts with Programs, v. 19, no. 5, p. 332.

1458. Schroedl, A.R., 1976, The archaic of the northern Colorado Plateau: Salt Lake City, University of Utah, Ph.D. dissertation, 122 p.

1459. Schumm, S.A., and Lusby, G.C., 1963, Seasonal variation of infiltration capacity and runoff on hillslopes in western Colorado: Journal of Geophysical Research, v. 68, no. 11, p. 3655-3666.

1460. Schwarz, F.P., Jr., 1967, Geology and ore deposits of Minnie Gulch, San Juan County, Colorado: Golden, Colorado School of Mines, Ph.D. dissertation, 2 volumes, maps.

1461. Schwochow, S.D., 1975, Preliminary sand and gravel resources map of the Pear Park study area, Mesa County, Colorado: Colorado Geological Survey Open-File Report 75-10, scale 1:12,000. 
1462. Scott, G.L., and Klipping, Sharon, 1981, Seismic surveying, Salt Anticline region, Paradox basin, in Wiegand, D.L., ed., Geology of the Paradox basin: Rocky Mountain Association of Geologists field conference, [Guidebook], v. 1981, p. 161-168.

1463. Scott, G.R., and Moore, D.W., 1981, Generalized surficial geologic map of the Kline Quadrangle, Colorado: U.S. Geological Survey Open-File Report 81-1317, scale 1:24,000.

1464. Scott, R.C., and Barker, F.B., 1961, Ground-water sources containing high concentrations of radium, in Short papers in the geologic and hydrologic sciences: U.S. Geological Survey Professional Paper 424-D, p. D357.

1465. Scott, R.C., and Barker, F.B., 1962, Data on uranium and radium in ground water in the United States, 1954 to 1957: U.S. Geological Survey Professional Paper 426, 115 p.

1466. Scott, R.C., and Voegeli, P.T., Sr., 1961, Radiochemical analyses of ground and surface water in Colorado, 1954-1961: Colorado Water Conservation Board Basic-Data Report 7, 27 p.

1467. Scott, R.W., Jr., and Pantea, M.P., 1985, Preliminary geologic map of the Dragon Quadrangle, Uintah County, Utah, and Rio Blanco County, Colorado: U.S. Geological Survey Miscellaneous Field Studies Map MF-1774, scale $1: 24,000$.

1468. Seal, O.G., Jr., ed., 1957, Guidebook to the geology of the Uinta Basin, Intermountain Association of Petroleum Geologists, 8 th annual field conference, 1957: [Salt Lake City], Intermountain Association of Petroleum Geologists, 224 p.

1469. Sears, J.D., 1925, Geology and oil and gas prospects of part of Moffat County, Colorado, and southern Sweetwater County, Wyoming, in chap. $G$ of Contributions to economic geology, 1923-24--Part 2, mineral fuels: U.S. Geological Survey Bulletin 751, p. 269-319.

1470. Sears, J.W., Graff, P.J., and Holden, G.S., 1982, Tectonic evolution of lower Proterozoic rocks, Uinta Mountains, Utah and Colorado: Geological Society of America Bulletin, v. 93, no. 10, p. 990-997.

1471. Seay, J.G., Jr., 1970, The geology of the northern Piceance Creek basin, northwestern Colorado: Athens, University of Ohio, Master's thesis, unknown pagination.

1472. Segerstrom, Kenneth, and Young, E.J., 1972, General geology of the Hahns Peak and Farwell Mountain Quadrangles, Routt County, Colorado, with a discussion of Upper Triassic and pre-Morrison Jurassic rocks, by G.N. Pipiringos: Geological Survey Bulletin 1349, 63 p.

1473. Senseny, P.E., Cain, P.J., and Callahan, G.D., 1983, Influence of deformation history on permeability and specific storage of Mesaverde Sandstone, in Mathewson, C.C., ed., Proceedings of the 24th U.S. symposium on rock mechanics--Theory, experiment, practice: College Station, Tex., June 20-23, 1983, Proceedings, v. 24, p. 525-531.

1474. Sepehr, M., James, L.D., and Duffy, C., 1985, Hydrologic modeling for identification of salinity sources in a stream-aquifers system--A case study, in Proceedings of the Association of Ground Water Scientists and Engineers, Western Regional Ground Water Conference, Reno, Nev., Jan. 15-16, 1985: Association of Ground Water Scientists and Engineers, p. $156-185$.

1475. Serna-Isaza, Mario, 1971, Geology and geochemistry of Calico Peak, Dolores County, Colorado: Golden, Colorado School of Mines, Master's thesis, $88 \mathrm{p}$. 
1476. Severy, C.L., 1955, Geology of the Williams Park-Fish Creek Anticlines, Routt County, Colorado, in Ritzma, H.R., and Oriel, S.S., eds., Guidebook to the geology of northwest Colorado, Intermountain Association of Petroleum Geologists, 6th annual field conference, and Rocky Mountain Association of Geologists annual field conference, 1955: Salt Lake City, Intermountain Association of Petroleum Geologists, p. 116-118.

1477. Seymour, David, 1962, Geologic features of the Mount Guyot area, Summit County, Colorado: Golden, Colorado School of Mines, Master's thesis, $102 \mathrm{p}$.

1478. Shaler, M.K., 1907, A reconnaissance survey of the western part of the Durango-Gallup Coal Field of Colorado and New Mexico, in chap. F, Coal fields of New Mexico and California, of Contributions to economic geology, 1906--Part 2, Coal, lignite, and peat: U.S. Geological Survey Bulletin 316, p. 376-426.

1479. Sharp, W.N., Martin, R.A., and Lane, M.E., 1983, Mineral resource potential and geologic map of the Powderhorn Wilderness study area and Cannibal Plateau wilderness roadless area, Gunnison and Hinsdale Counties, Colorado: U.S. Geological Survey Miscellaneous Field Studies Map MF-1483-A, 6 p., scale 1:50,000.

1480. Sharps, S.L., 1955, Correlation of pre-Mancos, post-Weber Formations, northwestern Colorado, in Ritzma, H.R., and Oriel, S.S., eds., Guidebook to the geology of northwest Colorado, Intermountain Association of Petroleum Geologists, 6th annual field conference, and Rocky Mountain Association of Geologists annual field conference, 1955: Salt Lake City, Intermountain Association of Petroleum Geologists, p. 16-17.

1481. Sharps, S.L., 1956, Geology of King Mountain, Routt County, Colorado, and correlation of pre-Mancos (Cretaceous), post-Weber (Permian) Formations, northwestern Colorado: Boulder, University of Colorado, Master's thesis, $92 \mathrm{p}$.

1482. Sharps, S.L., 1962, Geology of Pagoda Quadrangle, northwestern Colorado--Moffat, Routt, Rio Blanco, and Garfield Counties: Boulder, University of Colorado, Ph.D. dissertation, $282 \mathrm{p}$.

1483. Shaw, E.S., 1947, Surface geology between wolcott and Glenwood Canyon, in Guidebook of field conference in central Colorado, June 16, 17, 18, and 19, 1947: Denver, Rocky Mountain Association of Geologists, p. 60.

1484. Shawe, D.R., 1956, Slick Rock district, San Miguel and Dolores Counties, Colorado: U.S. Geological Survey Trace Element Investigations Report TEI-640, p. 36-46.

1485. Shawe, D.R., 1968, Petrography of sedimentary rocks in the Slick Rock district, San Miguel and Dolores Counties, Colorado: U.S. Geological Survey Professional Paper 576-B, p. B1-B34.

1486. Shawe, D.R., 1970, Structure of the Slick Rock district and vicinity, San Miguel and Dolores Counties, Colorado: U.S. Geological Survey Professional Paper 576-C, 18 p.

1487. Shawe, D.R., Archbold, N.L., and Simmons, G.C., 1959, Geology and uranium-vanadium deposits of the Slick Rock district, San Miguel and Dolores Counties, Colorado: Economic Geology, v. 54, no. 3, p. 395-415.

1488. Shawe, D.R., Poole F.G., and Heyl, A.V., 1978, Geologic framework of the region traversed by field excursion $\mathrm{C}-3$ in eastern Utah-western and central Colorado and by field excursion $\mathrm{C}-$ ? in eastern Utah-southwestern and central Colorado, in Shawe, D.R., ed., Guidebook on fossil fuels and *ist Colorado: Professional Contribution of Colorado School of Mines 9 , p. $2-17$. 
1489. Shawe, D.R., Simmons, G.C., and Archbold, N.L., 1957, Slick Rock district, Colorado: U.S. Geological Survey Trace Element Investigations Report TEI-690, book 1, p. 41-66.

1490. Shawe, D.R., Simmons, G.C., and Archbold, N.L., 1968, Stratigraphy of Slick Rock district and vicinity, San Miguel and Dolores Counties, Colorado: U.S. Geological Survey Professional Paper 576-A, p. A1-A108.

1491. Shawe, D.R., Simmons, G.C., and Rogers, W.B., 1961, Preliminary geologic map of the Slick Rock district, San Miguel and Dolores Counties, Colorado: U.S. Geological Survey Mineral Investigations Field Studies Map MF-203, scale 1:48,000.

1492. Shearer, E.M., 1951, Geology of Red Dirt Creek area, Eagle County, Colorado: Boulder, University of Colorado, Master's thesis, $46 \mathrm{p}$.

1493. Shearer, E.M., 1957, Geology of the Hot Sulphur Springs area, Grand County, Colorado, in Finch, W.C., ed., Guidebook to the geology of North and Middle Park basins, Colorado: Denver, Rocky Mountain Association of Geologists, p. 99-103.

1494. Shepherd, R.G., 1982, Critique of ground water modeling in the Piceance basin, in Gary, J.H., ed., Fifteenth Oil Shale Symposium Proceedings: Golden, Colorado School of Mines Press, p. 559-572.

1495. Shepherd, R.G., 1987, Transient calibration of computer model of ground water flow and transport, Piceance basin, Colorado: Journal of Environmental Science and Health, Part A, Environmental Science and Engineering, v. 22 , no. 8 , p. 683-705.

1496. Sheridan, D.S., 1950, Permian?, Triassic and Jurassic stratigraphy of the McCoy area of west-central Colorado: Compass, v. 27, no. 3, p. 126-147.

1497. Sheridan, D.S., 1950, Permian, Triassic, and Jurassic stratigraphy of the McCoy area (Routt, Grand, and Eagle Counties), west-central Colorado: Boulder, University of Colorado, Master's thesis, $96 \mathrm{p}$.

1498. Sheriff, S.D., 1976, Paleomagnetism of the San Juan volcanic field, southwestern Colorado: Bellingham, Western Washington State College, Master's thesis, unknown pagination.

1499. Shine, B.F., 1985, Engineering geology of the Battle Mountain landslide south of Minturn, Colorado: Golden, Colorado School of Mines, Master's thesis, $125 \mathrm{p}$.

1500. Shoemaker, E.M., 1955, Geology of the Juanita Arch Quadrangle, Colorado: U.S. Geological Survey Geologic Quadrangle Map GQ-81, scale 1:24,000.

1501. Shoemaker, E.M., 1955, Preliminary geologic map of the Juanita Arch Quadrangle, Colorado: U.S. Geological Survey Mineral Investigations Field Studies Map MF-28, scale 1:24,000.

1502. Shoemaker, E.M., 1956, Geology of the Roc Creek Quadrangle, Colorado: U.S. Geological Survey Geologic Quadrangle Map GQ-83, scale 1:24,000.

1503. Shomaker, J.W., 1971, Pagosa Springs Cretaceous area, in Strippable low-sulfur coal resources of the San Juan basin in New Mexico and Colorado: New Mexico Bureau of Mines and Mineral Resources Memoir 25, p. 99-102.

1504. Shomaker, J.W., 1971, Mesa Verde, Durango, and Barker Creek Mesaverde areas, in Strippable low-sulfur coal resources of the San Juan basin in New Mexico and Colorado: New Mexico Bureau of Mines and Mineral Resources Memoir 25, p. 45-47.

1505. Shultz, A.W., 1984, Subaerial debris-flow deposition in the upper Paleozoic Cutler Formation, western Colorado: Journal of Sedimentary Petrology, v. 54, no. 3, p. 758-772. 
1506. Siepman, B.R., 1985, Stratigraphy and petroleum potential of Trout Creek and Twentymile Sandstones (Upper Cretaceous), Sand Wash basin, Colorado: Colorado School of Mines Quarterly, v. 80, no. 2, 59 p.

1507. Siepman, B.R., 1986, Facies relationships in Campanian wave-dominated coastal deposits in Sand Wash basin, in Stone, D.S., and Johnson, K.S., eds., New interpretations of northwest Colorado geology: Denver, Rocky Mountain Association of Geologists Guidebook, p. 157-164.

1508. Sikkink, P.G.L., 1987, Lithofacies relationships and depositional environment of the Tertiary $0 j o$ Alamo Sandstone and related strata, San Juan basin, New Mexico and Colorado, in Fassett, J.E., and Rigby, J.K., Jr., eds., The Cretaceous-Tertiary boundary in the San Juan and Raton basins, New Mexico and Colorado: Geological Society of America Special Paper 209, p. 81-104.

1509. Simmons, G.C., 1957, Contact of Burro Canyon Formation with Dakota Sandstone, Slick Rock district, Colorado, and correlation of Burro Canyon Formation: American Association of Petroleum Geologists Bulletin, v. 41, no. 11 , p. 2519-2529.

1510. Sinclair, William, 1963, Geology of the Upper East Fork of the San Juan River area, Mineral and Archuleta Counties, Colorado: Golden, Colorado School of Mines, Master's thesis, $133 \mathrm{p}$.

1511. Sinclair, William, 1964, Geology of the Quartz Creek Anticline, Mineral and Archuleta Counties, Colorado: Mountain Geologist, v. 1, no. 2, p. 67-71.

1512. Singer, D.A., 1968, Petrographic investigation of three cored wells of the Salt Wash Member of the Morrison Formation, Montrose County, Colorado: University Park, Pennsylvania State University, Master's thesis, unknown pagination.

1513. Singewald, Q.D., 1947, Preliminary geologic map and sections of the upper Blue River area, Summit County, Colorado [with text]: U.S. Geological Survey, scale 1:31,250.

1514. Singewald, Q.D., 1951, Geology and ore deposits of the upper Blue River area, Summit County, Colorado: U.S. Geological Survey Bulletin 970, $74 \mathrm{p}$.

1515. Skogerboe, G.V., 1982, The physical environment of the Colorado River basin: Water Supply and Management, v. 6, nos. 1-2, p. 11-27.

1516. Skogerboe, R.K., Lavallee, C.S., Miller, M.M., and Dick, D.L., 1979, Environmental effects of oil shale mining and processing--Part III, The water quality of Piceance Creek, Colorado, prior to oil shale processing: U.S. Environmental Protection Agency Report EPA 600/3-79-055, 59 p.

1517. Skougstad, M.W., and Horr, C.A., 1963, Occurrence and distribution of strontium in natural water: U.S. Geological Survey Water-Supply Paper 1496-D, p. 55-97.

1518. Slawson, G.C., Jr., ed., 1980, Groundwater quality monitoring of western oil shale development--Monitoring program development: U.S. Environmental Protection Agency Report EPA-600/7-80-089, 181 p.

1519. Slawson, G.C., Jr., ed., 1980, Monitoring groundwater quality--The impact of in situ oil shale retorting: U.S. Environmental Protection Agency Report EPA-600/7-80-132, 279 p.

1520. Slawson, G.C., Kelly, K.E., Jr., and Everett, L.G., 1982, Evaluation of ground-water pumping and bailing methods--Application in the oil shale industry: Ground Water Monitoring Review, v. 2, no. 3 (summer), p. 27-32.

1521. Slebir, E.J., 1957, Geology of North Cement Creek area, Gunnison County, Colorado: Golden, Colorado School of Mines, Master's thesis, 93 p. 
1522. Smith, B.M., Varga, R.J., and Gumble, G.E., 1984, Paleohydrology of the Bonanza trapdoor caldera, N.E. San Juan volcanic field, Colorado--0xygen isotopes and hydrothermal metamorphism of Rawley Andesite [abs.?], Eos, American Geophysical Union, Transactions, v. 65, no. 45, p. 1125 .

1523. Smith, M.C., and O'Sullivan, R.B., 1982, Results of core drilling in 1978 for oil shale in the Eocene Green River Formation, Piceance Creek area of western Colorado: U.S. Geological Survey Open-File Report $82-476,190 \mathrm{p}$.

1524. Smith, P.G., 1987, Stratigraphy and sedimentology of Devonian and Mississippian strata flanking the Homestake shear zone, northeastern Sawatch Uplift, Eagle County, Colorado: Golden, Colorado School of Mines, Master's thesis, $132 \mathrm{p}$.

1525. Snow, C.B., 1969, Stratigraphy of basal sandstones in the Green River Formation (Eocene, lower and middle), northwest Piceance basin, Rio Blanco County, Colorado: Golden, Colorado School of Mines, Master's thesis, $108 \mathrm{p}$.

1526. Snow, C.B., 1970, Stratigraphy of basalt sandstones in the Green River Formation, northeast Piceance basin, Rio Blanco County, Colorado:

Mountain Geologist, v. 7, no. 1, p. 3-32.

1527. Snyder, G.L., 1980, Geologic map of the central part of the northern Park Range, Jackson and Routt Counties, Colorado: U.S. Geological Survey Miscellaneous Investigations Series Map I-1112, scale 1:48,000.

1528. Snyder, G.L., 1980, Geologic map of the northernmost Park Range and southernmost Sierra Madre, Jackson and Routt Counties, Colorado: U.S. Geological Survey Miscellaneous Investigations Series Map I-1113, scale $1: 48,000$.

1529. Snyder, R.D., 1952, Geology of the east-central rectangle of the Red Mesa Quadrangle, La Plata County, Colorado: Urbana, Ill., University of Illinois, Master's thesis, $61 \mathrm{p}$.

1530. Snyder, R.P., and Terry, S.S., 1977, Subsurface geology and structure in the vicinity of three drill holes in Piceance Creek basin, Rio Blanco County, Colorado: U.S. Geological Survey Open-File Report 77-271, 78 p.

1531. Soar, L.K., 1984, Paleoecology of phylloid algal mud mounds, Honaker Train Formation (Pennsylvanian), southwest Colorado: Austin, University of Texas, Master's thesis, $69 \mathrm{p}$.

1532. Soeder, D.J., and Randolph, P.L., 1987, Porosity, permeability, and pore structure of the tight Mesaverde Sandstone, Piceance basin, Colorado: Society of Petroleum Engineers Formation Evaluation, v. 2, no. 2, p. 129-136.

1533. Sorini, S.S., and Donovan, R.C., 1986, EPA, ASTM, and column leaching of processed oil shale--A comparative study, in Gary, J.H., ed., Nineteenth Oil Shale Symposium Proceedings: Golden, Colorado School of Mines Press, p. 229-240.

1535. Spicker, F.A., 1973, The geology, alteration, and mineralization of Parkview Mountain, Grand and Jackson Counties, Colorado: Fort Collins, Colorado State University, Master's thesis, $96 \mathrm{p}$.

1536. Spitzer, R.H., Jirak, G.T., and Pawlak, S.L., 1986, Landslide stability achieved with horizontal drains, in Wood, S.H., ed., Proceedings of the 22d Symposium on Engineering Geology and Soils Engineering, Boise, Idaho, Feb. 24-26, 1986: Boise, Idaho, Boise State University, Department of Geology and Geophysics Proceedings 22, p. 266-280.

1537. Spock, L.E., Jr., 1928, Geological reconnaissance of parts of Grand, Jackson, and Larimer Counties, Colorado: New York Academy of Science Annals, v. 30, p. 177-261. 
1538. Spoelhof, R.W., 1974, Pennsylvanian stratigraphy and tectonics in the Lime Creek-Molas Lake area, San Juan County, Colorado: Golden, Colorado School of Mines, Ph.D. dissertation, 193 p.

1539. Spoelhof, R.W., 1976, Pennsylvanian stratigraphy and paleotectonics of the western San Juan Mountains, southwestern Colorado, in Epis, R.C., ed., Studies in Colorado field geology: Professional Contributions of Colorado School of Mines 8, p. 159-179.

1540. Staatz, M.H., and Trites, A.F., Jr., 1955, Geology of the Quartz Creek pegmatite district, Gunnison County, Colorado: U.S. Geological Survey Professional Paper 265, $111 \mathrm{p}$.

1542. Stancliffe, R.J., 1984, Vertically stacked barrier island system, Sego Sandstone (Campanian), northwest Colorado: [Austin?], University of Texas, Master's thesis, $156 \mathrm{p}$.

1543. Stancliffe, R.J., and Noe, D.C., 1984, Effect of sediment supply on embayed shoreline deposits, Cretaceous (Campanian), northwestern Colorado, in Stott, D.F., and Glass, D.J., eds., The Mesozoic of middle North America--Symposium, Calgary, Alberta, Canada, May 8-13, 1983, [Proceedings?]: Canadian Society of Petroleum Geologists Memoir 9, p. 562-563.

1544. Stanfield, K.E., and others, 1966, Progress report on Bureau of MinesAtomic Energy Commission corehole, Rio Blanco County, Colorado: Colorado School of Mines Quarterly, v. 61, no. 3, p. 33-44.

1545. Stark, J.T., 1935, Migmatites of the Sawatch Range, Colorado: Journal of Geology, v. 43, no. 1, p. 1-26.

1546. Stauffer, J.E., 1953, Geology of an area west of Wolcott, Eagle County, Colorado: Boulder, University of Colorado, Master's thesis, $56 \mathrm{p}$.

1547. Stearns, D.W., and Jamison, W.R., 1977, Deformation of sandstones over basement uplifts, Colorado National Monument, in Veal, H.K., ed., Exploration frontiers of the central and southern Rockies: [Denver], Rocky Mountain Association of Geologists field conference [Guidebook], v. 1977, p. 31-39.

1548. Stearns, N.D., Stearns, H.T., and Waring, G.A., 1937, Thermal springs in the United States: U.S. Geological Survey Water-Supply Paper 679-B, p. 59-206.

1549. Steele, B.A., 1985, Preliminary report on and measured sections of the Middle Jurassic Entrada Sandstone and Wanakah Formation near Placerville, southwestern Colorado: U.S. Geological Survey Open-File Report 85-446, $57 \mathrm{p}$.

1550. Steele, T.D., 1978, Assessment techniques for modeling water quality in a river basin affected by coal-resource development, in Symposium on Modeling the Water Quality of the Hydrological Cycle, Baden, Austria, Sept. 11-15, 1978, [Proceedings?]: International Association of Hydrological Sciences and International Institute for Applied Systems Analysis, $16 \mathrm{p}$.

1551. Steele, T.D., 1979, An overview of river-basin assessment techniques in an energy-impacted region--Yampa River basin, Colorado and Wyoming: Water Supply and Management, v. 3, no. 3, p. 151-171.

1552. Steele, T.D., Bauer, D.P., Wentz, D.A., and Warner, J.A., 1976, An environmental assessment of impacts of coal development on the water resources of the Yampa River basin, Colorado and Wyoming--Phase I work plan: U.S. Geological Survey Open-File Report 76-367, 38 p. 
1553. Steele, T.D., Bauer, D.P., Wentz, D.A., and Warner, J.W., 1979, The Yampa River basin, Colorado and Wyoming--A preview to expanded coalresource development and its impacts on regional water resources: U.S. Geological Survey Water-Resources Investigations Report 78-126, $142 \mathrm{p}$. [Available from National Technical Information Services, U.S. Department of Commerce, Springfield, VA 22161 as PB-300 815.]

1554. Steele, T.D., and Hillier, D.E., comps., 1981, Assessment of impacts of proposed coal-resource and related economic development on water resources, Yampa River basin, Colorado and Wyoming--A summary: U.S. Geological Survey Circular 839, 56 p.

1555. Steele, T.D., Wentz, D.A., and Warner, J.W., 1978, Hydrologic reconnaissance of the Yampa River during low flow, Dinosaur National Monument, northwestern Colorado: U.S. Geological Survey Open-File Report 78-226, $24 \mathrm{p}$.

1556. Steinbach, R.C., 1956, Geology of the Azure area, Grand County, Colorado: Boulder, University of Colorado, Master's thesis, $90 \mathrm{p}$.

1557. Steven, T.A., 1964, Geologic setting of the Spar City district, San Juan Mountains, Colorado, in Short papers in geology and hydrology: U.S. Geological Survey Professional Paper 475-D, p. D123-D127.

1558. Steven, T.A., 1967, Geologic map of the Bristol Head Quadrangle, Mineral and Hinsdale Counties, Colorado: U.S. Geological Survey Geologic Quadrangle Map GQ-631, scale 1:62,500.

1559. Steven, T.A., 1968, Critical review of the San Juan peneplain, southwestern Colorado: U.S. Geological Survey Professional Paper 594-I, p. I1-I19.

1560. Steven, T.A., and Hail, W.J., Jr., 1989, Geologic map of the Montrose 30-by 60-Minute Quadrangle, southwestern Colorado: U.S. Geologica1 Survey Miscellaneous Investigations Series Map I-1939, scale 1:100,000.

1561. Steven, T.A., and Lipman, P.W., 1973, Geologic map of the Spar City Quadrangle, Mineral County, Colorado: U.S. Geological Survey Geologic Quadrangle Map GQ-1052, scale 1:62,500.

1562. Steven, T.A., Lipman, P.W., Hail, W.J., Jr., Barker, Fred, and Luedke, R.G., comps., 1974, Geologic map of the Durango Quadrangle, southwestern Colorado: U.S. Geological Survey Miscellaneous Investigations Series Map I-764, scale 1:250,000. (Reprinted in 1978.)

1563. Steven, T.A., and MacLachlan, J.C., 1953, Geology of the Summitville mining district, Colorado: Mines Magazine, v. 43, no. 3, p. 18.

1564. Steven, T.A., and Ratte, J.C., 1960, Geology and ore deposits of the Summitville district, San Juan Mountains, Colorado: U.S. Geological Survey Professional Paper 343, 70 p.

1565. Steven, T.A., and Ratte, J.C., 1965, Geology and structural control of ore deposition in the Creede district, San Juan Mountains, Colorado: U.S. Geological Survey Professional Paper 487, 90 p.

1566. Steven, T.A., and Ratte, J.C., 1973, Geologic map of the Creede Quadrangle, Mineral and Saguache Counties, Colorado: U.S. Geological Survey Geologic Quadrangle Map GQ-1053, scale 1:62,500.

1567. Stevens, C.H., 1958, Stratigraphy and paleontology of the McCoy (Routt and Eagle Counties), Colorado area: Boulder, University of Colorado, Master's thesis, $242 \mathrm{p}$.

1568. Stevens, R.P., 1886, On the San Juan Mountains: New York Academy of Science Transactions, v. 5, p. 121-130.

1569. Stevenson, A.E., 1978, Lithologic and geophysical logs for eight holes drilled during 1978 in the Rattlesnake Butte Quadrangle, Routt County, Colorado: U.S. Geological Survey Open-File Report 78-1048, 28 p. 
1570. Stevenson, G.M., and Baars, D.L., 1984, Paradox basin--A model pullapart basin of Pennsylvanian age: American Association of Petroleum Geologists Bulletin, v. 68, no. 7, p. 950-951.

1571. Stevenson, J.J., 1875, Report on the geology of a portion of Colorado: U.S. Geological and Geographical Survey West of 100th Meridian (Wheeler) 3, p. 303-501.

1572. Stewart, Michael, 1983, Hydrogeology of the upper part of the Mesaverde Group, Williams Fork Mountains, Routt and Moffat Counties, Colorado: Golden, Colorado School of Mines, Master's thesis, $210 \mathrm{p}$.

1573. Stieff, L.R., Stieff, C.B., and Nelson, R.A., 1987, Field measurements of in situ (222)Rn concentrations in soil based on the prompt decay of the (214)Bi counting rate: Nuclear Physics, v. 1, no. 2, p. 183-195.

1574. Stoddard, R.R., 1957, Geology of a portion of south-central Archuleta County, Colorado: Golden, Colorado School of Mines, Master's thesis, $178 \mathrm{p}$.

1575. Stokes, W.L., and Phoenix, D.A., 1948, Geology of the Egnar-Gypsum Valley area, San Miguel and Montrose Counties, Colorado: U.S. Geological Survey $0 i 1$ and Gas Investigations Map OM-93, scale 1:48,000.

1576. Stokes, W.L., Russel1, R.T., Fischer, R.P., and Butler, A.P., Jr., 1945, Geologic map of the Gateway area, Mesa County, Colorado, and adjoining part of Grand County, Utah: U.S. Geological Survey Mineral Investigations Preliminary Strategic Map 3-173, scale $1: 63,360$.

1577. Stollenwerk, K.G., 1980, Geochemistry of leachate from retorted and unretorted Colorado oil shale: Boulder, University of Colorado, Ph.D. dissertation, $236 \mathrm{p}$.

1578. Stollenwerk, K.G., 1984, Adsorption and desorption of hexavalent chromium in an alluvial aquifer near Telluride, Colorado, in Program overview and selected papers from the Toxic-Waste Program Technical Meeting, Tucson, Ariz., March 20-22, 1984: U.S. Geological Survey Open-File Report 324, p. 97-100.

1579. Stollenwerk, K.G., 1987, Chemical effects and control of leachates from oil-shale spoil piles, in Taylor, 0.J., ed., 0il shale, water resources and valuable minerals of the Piceance basin, Colorado--The challenge and choices of development: U.S. Geological Survey Professional Paper 1310, p. 107-110.

1580. Stollenwerk, K.G., and Grove, D.B., 1985, Adsorption and desorption of hexavalent chromium in an alluvial aquifer near Telluride, Colorado:

Journal of Environmental Quality, v. 14, no. 1, p. 150-155.

1581. Sumsion, C.T., 1976, Water resources of Dinosaur National Monument, Colorado and Utah: U.S. Geological Survey Open-File Report 76-580, 70 p.

1582. Sweetser, A.L., 1911, The La Plata Mountains: Mining Science, v. 64, p. 229 .

1583. Szabo, E., and Wengerd, S.A., 1975, Stratigraphy and tectogenesis of the Paradox basin, in Canyonlands country, Four Corners Geological Society, 8th field conference, Guidebook: [Durango, Colo.], Four Corners Geological Society, p. 193-210.

1584. Tait, D.B., 1982, Piceance basin hydrology--Aquitards and aquicludes, in Gary, J.H., ed., Fifteenth Oil Shale Symposium Proceedings: Golden, Colorado School of Mines Press, p. 155-156.

1585. Tank, R.W., 1958, Standard nomenclature and general stratigraphic correlations in the Four Corners area of the Paradox basin, in Sanborn, A.F., ed., Guidebook to the geology of the Paradox basin: Salt Lake City, Intermountain Association of Petroleum Geologists, 9 th annual field conference, p. 9. 
1586. Taranik, J.V., 1974, Stratigraphic and structural evolution of Breckrenridge area, central Colorado: Golden, Colorado School of Mines, $\mathrm{Ph} . \mathrm{D}$. dissertation, $221 \mathrm{p}$.

1587. Taylor, 0.J., 1982, Hydrologic-information needs for oil-shale development, northwestern Colorado: U.S. Geological Survey Water-Resources Investigations Report 82-4076, $92 \mathrm{p}$.

1588. Taylor, 0.J., 1982, Three-dimensional mathematical model for simulating the hydrologic system in the Piceance basin, Colorado: U.S. Geological Survey Open-File Report 82-637, $91 \mathrm{p}$.

1589. Taylor, 0.J., 1985, Simulation of mine drainage of oil-shale deposits, Piceance basin, Colorado, U.S.A.: Mine Water Proceedings of the Second International Congress, Granada, Spain, Sept. 1985, p. 571-577.

1590. Taylor, 0.J., 1986, Simulation of mine drainage for preliminary development of oil shale and associated minerals, Piceance basin, northwestern Colorado: U.S. Geological Survey Water-Resources Investigations Report $86-4011,25 \mathrm{p}$.

1591. Taylor, 0.J., 1987, Hydrologic system of Piceance basin, in Taylor, $0 . J .$, ed., 0il shale, water resources, and valuable minerals of the Piceance basin, Colorado--The challenge and choices of development: U.S. Geological Survey Professional Paper 1310, p. 63-76.

1592. Taylor, 0.J., ed., 1987, Oil shale, water resources, and valuable minerals of the Piceance basin, Colorado--The challenge and choices of development: U.S. Geological Survey Professional Paper 1310, 143 p.

1593. Taylor, 0.J., 1988, Predicted effects of underground mine flooding at Tract $\mathrm{C}-\mathrm{b}$ in Piceance basin, northwestern Colorado: U.S. Geological Survey Water-Resources Investigations Report 87-4189, $16 \mathrm{p}$.

1594. Taylor, 0.J., Freethey, G., and Glover, K.C., 1986, Upper Colorado River Basin regional aquifer-system study, in Regional aquifer-system analysis program of the U.S. Geological Survey--Summary of projects: U.S. Geological Survey Circular 1002, p. 223-233.

1595. Taylor, O.J., and Hood, J.W., 1988, Region 3, Colorado Plateau and Wyoming Basin, in Back, William, Rosenshein, J.S., and Seaber, P.R., eds., Hydrogeology: Boulder, Colo., Geological Society of America, p. 51-58.

1596. Taylor, 0.J., and Hood, J.W., 1988, Region 3, Colorado Plateau and Wyoming Basin, in Hydrogeology: Boulder, Colo., Geological Society of North America, p. 51-58.

1597. Taylor, O.J., Hood, J.W., and Zimmerman, E.A., 1986, Hydrogeologic framework of the Upper Colorado River Basin--excluding the San Juan basin--Colorado, Utah, Wyoming, and Arizona: U.S. Geological Survey Hydrologic Investigations Atlas HA-687, 2 sheets, scale 1:3,000,000.

1598. Taylor, R.B., 1975, Geologic map of the Bottle Pass Quadrangle, Grand County, Colorado: U.S. Geological Survey Geologic Quadrangle Map GQ-1224, scale $1: 24,000$.

1599. Teller, R.W., and Chafin, D.T., 1986, Selected drill-stem test data for the Upper Colorado River Basin: U.S. Geological Survey Water-Resources Investigations Report 84-4146, $112 \mathrm{p}$.

1600. Tewksbury, B.J., 1984, Proterozoic geology of the Needle Mountains, Colorado [abs.]: Geological Society of America, Abstracts with Programs, v. 16 , no. 4, p. 257-258.

1601. Thaden, R.E., and Zech, R.S., 1984, Preliminary structure contour map on the base of the Cretaceous Dakota Sandstone in the San Juan basin and vicinity, New Mexico, Arizona, Colorado, and Utah: U.S. Geological Survey Miscellaneous Field Studies Map MF-1673, scale 1:500,000. 
1602. Thaden, R.E., and Zech, R.S., 1986, Structure contour map of the San Juan basin and vicinity, in Turner-Peterson, C.E., Santos, E.S., and Fishman, M.S., eds., A basin analysis case study--The Morrison Formation, Grants uranium region, New Mexico: American Association of Petroleum Geologists Studies in Geology 22, p. 35-45.

1603. Theobald, P.K., 1965, Preliminary geologic map of the Berthoud Pass Quadrangle, Clear Creek and Grand Counties, Colorado: U.S. Geological Survey Miscellaneous Geologic Investigations Map I-443, scale 1:24,000.

1604. Thomaidis, N.D., 1978, Stratigraphy and oil and gas production--Colorado (southwest), in Fassett, J.E., ed., Oil and gas fields of the Four Corners area: [Durango, Colo.], Four Corners Geological Society, p. 43-44.

1605. Thomas, B.E., 1989, Simulation analysis of the ground-water system in Mesozoic rocks in the Four Corners area, Utah, Colorado, Arizona, and New Mexico: U.S. Geological Survey Water-Resources Investigations Report $88-4086,89 \mathrm{p}$.

1606. Thomas, C.R., McCann, F.T., and Ramon, N.D., 1945, Mesozoic and Paleozoic stratigraphy in northwestern Colorado and northeastern Utah: U.S. Geological Survey $0 i 1$ and Gas Investigations Chart 0C-16, 2 sheets, vertical scale $1: 2,400$; horizontal scale 1:696,960.

1607. Thomas, C.R., and others, 1944, Structure contour map of the exposed rocks in the Rangely Anticline, Rio Blanco and Moffat Counties, Colorado: U.S. Geological Survey $0 i 1$ and Gas Investigations Map OM-7, scale $1: 31,680$.

1608. Thomas, C.R., and others, 1945, Structure contour maps of the Rangely Anticline, Rio Blanco and Moffat Counties, Colorado: U.S. Geological Survey 0il and Gas Investigations Map OM-41, scale $1: 31,680$.

1609. Thomas, H.E., 1952, Hydrologic reconnaissance of the Green River in Utah and Colorado: U.S. Geological Survey Circular 129, 32 p.

1610. Thomas, H.E., 1952, Ground-water regions of the United States--Their storage facilities, in The physical and economic foundation of natural resources [Report for U.S. Congress, House of Representatives Interior and Insular Affairs Committee, U.S. Congress, 83d]: Washington, D.C., U.S. Government Printing Office, v. 3, various pagination.

1611. Thomas, H.E., 1962, The meteorologic phenomenon of drought in the Southwest: U.S. Geological Survey Professional Paper 372-A, 43 p.

1612. Thomas, H.E., and others, 1963, Effects of drought in the Colorado River basin: U.S. Geological Survey Professional Paper 372-F, 51 p.

1613. Thomas, M.H., 1981, Stratigraphy of the Dakota and Burro Canyon Formations near Gunnison, Colorado: Golden, Colorado School of Mines, Master's thesis, $76 \mathrm{p}$.

1614. Thomas, W.A., 1971, Devonian stratigraphy north of the Uncompahgre Uplift, Colorado: Mountain Geologist, v. 8, no. 2, p. 85-88.

1615. Thorn, C.R., and Dam, W.L., 1988, Use of a geographic information system to display water-quality data from the San Juan basin, New Mexico, Colorado, Arizona, and Utah, in Thomas, H.F., ed., GIS--Integrating technology and geoscience applications: Washington, D.C., National Academy of Science, p. 10-11.

1616. Thurman, F.A., 1954, A geologic history of Colorado, in The 0il and Gas Fields of Colorado Symposium: [Denver?], Rocky Mountain Geological Society, p. 25-34.

1617. Tillman, R.W., 1966, Petrology and paleoenvironments of the Robinson Member, Minturn Formation (Pennsylvanian), Eagle basin (Routt, Grand, and Eagle Counties), Colorado: Boulder, University of Colorado, Ph.D. dissertation, 227 p. 
1618. Tobin, R.L., 1987, Water quality in the Piceance basin, in Taylor, 0.J., ed., Oil shale, water resources, and valuable minerals of the Piceance basin, Colorado--The challenge and choices of development: U.S. Geological Survey Professional Paper 1310, p. 81-85.

1619. Todd, D.K., 1959, Annotated bibliography on artificial recharge of ground water through 1954: U.S. Geological Survey Water-Supply Paper $1477,115 \mathrm{p}$.

1620. Toenges, A.L., and others, 1949, Reserves, petrographic and chemical characteristics, and carbonizing properties of coal occurring south of Dry Fork of Minnesota Creek, Gunnison County, near Paonia, Colorado, and the geology of the area: U.S. Bureau of Mines Technical Paper $721,48 \mathrm{p}$.

1621. Toll, R.H., 1908, La Plata Mountains, Colorado: San Francisco, Mining and Scientific Press, v. 97, p. 741-744.

1622. Tollefson, 0.W., 1956, Geology of central Middle Park, Colorado: Boulder, University of Colorado, Ph.D. dissertation, 148 p.

1623. Tramme11, J.W., 1961, Geology of the Cumberland Pass area, Gunnison County, Colorado: Boulder, University of Colorado, Master's thesis, $109 \mathrm{p}$.

1624. Trask, N.J., 1956, Geology of the Buford area, Rio Blanco County, Colorado: Boulder, University of Colorado, Master's thesis, $90 \mathrm{p}$.

1625. Traupe, L.D., 1939, Ancestra1 Rockies of Colorado in Permo-Pennsylvanian times: Compass, v. 19, no. 2, p. 121-124.

1626. Trexler, D.W., 1974, Fold structures in the Piceance Creek basin area, Colorado from ERTS-1 imagery, in Murray, D.K., ed., Energy resources of the Piceance Creek basin, Colorado: Denver, Rocky Mountain Association of Geologists, 25th field conference, Guidebook, p. 41-45.

1627. Troendle, C.A., and King, R.M., 1987, The effect of partial and clearcutting on streamflow at Deadhorse Creek, Colorado: Journal of Hydrology, v. 90, nos. 1-2, p. 145-157.

1628. Trudell, L.G., Beard, T.N., and Smith, J.W., 1974, Stratigraphic framework of Green River Formation oil shales in the Piceance Creek basin, Colorado, in Murray, D.K., ed., Energy resources of the Piceance Creek basin, Colorado: Denver, Rocky Mountain Association of Geologists, 25th field conference, Guidebook, p. 65-70.

1629. Turk, J.T., 1982, Thermodynamic controls on quality of water from underground coal mines in Colorado: Water Resources Bulletin, v. 18, no. 1 , p. 75-80.

1630. Turk, J.T., and Parker, R.S., 1982, Water-quality characteristics of six small, semiarid watersheds in the Green River coal region of Colorado: U.S. Geological Survey Water-Resources Investigations Report 81-73, $101 \mathrm{p}$.

1631. Turnbow, D.R., 1955, Permian and Pennsylvanian rocks of the Four Corners area, in Cooper, J.C., ed., Geology of parts of Paradox, Black Mesa, and San Juan basins, [1st] Four Corners field conference, 1955, [Guidebook]: [Durango, Colo.], Four Corners Geological Society, p. 66-69.

1632. Turner-Peterson, C.E., 1987, Sedimentology of the Westwater Canyon and Brush Basin Members, Upper Jurassic Morrison Formation, Colorado Plateau, and relationship to uranium mineralization: Boulder, University of Colorado, Ph.D. dissertation, $184 \mathrm{p}$.

1633. Tweto, Ogden, 1949, Stratigraphy of the Pando area, Eagle County, Colorado: [Denver?], Colorado Scientific Society Proceedings, v. 15, no. 4, p. 149-235.

1634. Tweto, Ogden, 1951, Form and structure of sills near Pando, Colorado: Geological Society of America Bulletin, v. 62, no. 5, p. 507-531. 
1635. Tweto, Ogden, 1953, Geologic map of the Pando area, Eagle and Summit Counties, Colorado: U.S. Geological Survey Mineral Investigations Field Studies Map MF-12, scale 1:14,400.

1636. Tweto, Ogden, 1956, Geologic map of the Tennessee Pass area, Eagle and Lake Counties, Colorado: U.S. Geological Survey Mineral Investigations Field Studies Map MF-34, scale 1:14,400.

1637. Tweto, Ogden, 1957, Geologic sketch of southern Middle Park, Colorado, in Finch, W.C., ed., Guidebook to the geology of North and Middle Parks basin, Colorado: Denver, Rocky Mountain Association of Geologists, p. 18-31.

1638. Tweto, Ogden, 1958, Pennsylvanian stratigraphic section in the MinturnPando area, Colorado, in Curtis, B.F., ed., Symposium on Pennsylvanian rocks of Colorado and adjacent areas, 1958: Denver, Rocky Mountain Association of Geologists, p. 80-85.

1639. Tweto, Ogden, 1974, Geologic map and sections of the Holy Cross Quadrangle, Eagle, Lake, Pitkin, and Summit Counties, Colorado: U.S. Geological Survey Miscellaneous Investigations Series Map I-830, 2 sheets, scale $1: 24,000$.

1640. Tweto, Ogden, 1974, Geologic map of the Mount Lincoln 15-Minute Quadrangle, Eagle, Lake, Park, and Summit Counties, Colorado: U.S. Geological Survey Miscellaneous Field Studies Map MF-556, scale 1:62,500. (Reprinted.)

1642. Tweto, Ogden, comp., 1975, Preliminary geologic map of the Craig $1^{\circ}$ by $2^{\circ}$ Quadrangle, northwestern Colorado: U.S. Geological Survey Miscellaneous Field Studies Map MF-666, scale 1:250,000. (Reprinted.)

1643. Tweto, Ogden, comp., 1976, Geologic map of the Craig $1^{\circ}$ by $2^{\circ}$ Quadrangle, northwestern Colorado: U.S. Geological Survey Miscellaneous Investigations Series Map I-972, scale 1:250,000. (Reprinted in 1981.)

1644. Tweto, Ogden, comp., 1976, Preliminary geologic map of Colorado: U.S. Geological Survey Miscellaneous Field Studies Map MF-788, 2 sheets, scale $1: 500,000$. (Reprinted.)

1645. Tweto, Ogden, 1977, Nomenclature of Precambrian rocks in Colorado: U.S. Geological Survey Bulletin 1422-D, 22 p.

1646. Tweto, Ogden, comp., 1979, [1980], Geologic map of Colorado: U.S. Geological Survey State Geologic Map, scale 1:500,000. (Reprinted.)

1647. Tweto, Ogden, 1980, Precambrian geology of Colorado, in Kent, H.C., and Porter, K.W., eds., Colorado geology: Denver, Rocky Mountain Association of Geologists, p. 37-46, scale 1:200,000.

1648. Tweto, Ogden, 1980, Summary of Laramide Orogeny in Colorado, in Kent, H.C., and Porter, K.W., eds., Colorado geology: Denver, Rocky Mountain Association of Geologists, p. 129-134.

1649. Tweto, Ogden, 1980, Tectonic history of Colorado, in Kent, H.C., and Porter, K.W., eds., Colorado geology: Denver, Rocky Mountain Association of Geologists, p. 5-9.

1650. Tweto, Ogden, 1983, Geologic sections across Colorado: U.S. Geological Survey Miscellaneous Investigations Series Map I-1416.

1651. Tweto, Ogden, 1987, Rock units of the Precambrian basement in Colorado: U.S. Geological Survey Professional Paper 1321-A, p. A1-A54.

1652. Tweto, Ogden, and Lovering, T.S., 1977, Geology of the Minturn 15-Minute Quadrangle, Eagle and Summit Counties, Colorado: U.S. Geological Survey Professional Paper 956, 96 p., scale 1:48,000.

1653. Tweto, Ogden, Moench, R.H., and Reed, J.C., Jr., 1976, Preliminary geologic map of the Leadville $1^{\circ}$ by $2^{\circ}$ Quadrangle, northwestern Colorado: U.S. Geological Survey Miscellaneous Field Studies Map MF-760, scale $1: 250,000$. 
1654. Tweto, Ogden, Moench, R.H., and Reed, J.C., Jr., 1978, Geologic map of the Leadville $1^{\circ}$ by $2^{\circ}$ Quadrangle, northwestern Colorado: U.S.

Geological Survey Miscellaneous Investigations Series Map I-999, scale $1: 250,000$. (Reprinted.)

1655. Tweto, Ogden, Steven, T.A., Hail, W.J., Jr., and Moench, R.H., 1976, Preliminary geologic map of the Montrose $1^{\circ}$ by $2^{\circ}$ Quadrangle, southwestern Colorado: U.S. Geological Survey Miscellaneous Field Studies Map MF-761, scale 1:250,000. (Reprinted.)

1657. Tyler, Noel, 1981, Jurassic depositional history and vanadium-uranium deposits, Slick Rock district, Colorado Plateau: Fort Collins, Colorado State University, Ph.D. dissertation, $285 \mathrm{p}$.

1658. Tyler, Noel, and Ethridge, F.G., 1983, Depositional setting of the Salt Wash Member of the Morrison Formation, southwest Colorado: Journal of Sedimentary Petrology, v. 53, no. 1, p. 67-82.

1659. U.S. Bureau of Land Management, 1983, Glenwood Springs resource management plan: U.S. Bureau of Land Management, Draft environmental impact statements, $255 \mathrm{p}$.

1660. U.S. Bureau of Reclamation, 1974, Water for tomorrow--Colorado State water plan--Phase I, Appraisal report on water and related land resources and their present utilization: U.S. Bureau of Reclamation, $15 \mathrm{p}$.

1661. U.S. Bureau of Reclamation, 1974, Report on water for energy in the Upper Colorado River Basin: U.S. Bureau of Reclamation, $71 \mathrm{p}$.

1662. U.S. Bureau of Reclamation, 1977, Colorado River water quality improvement program (final environmental statement): U.S. Bureau of Reclamation, Report FES 77-15, 2 vols.

1663. U.S. Geological Survey, 1904, Ouray Quadrangle: U.S. Geological Survey Special Map, scale $1: 62,500$.

1666. U.S. Geological Survey, 1965, Water resources data for Colorado--Part 2, Water-quality records: U.S. Geological Survey, $130 \mathrm{p}$.

1667. U.S. Geological Survey, 1982, Water resources data for Colorado, water year 1980--Volume 3, Dolores River basin, Green River basin, and San Juan River basin: U.S. Geological Survey, 467 p. [Available from National Technical Information Service, U.S. Department of Commerce, Springfield, VA 22161 as PB82-202 045.]

1669. U.S. Geological Survey, and Colorado Mining Industrial Development Board, 1964, Mineral and water resources of Colorado: Washington, D.C., U.S. Congress, $88 \mathrm{th}, 2 \mathrm{~d}$ Session, Senate Commission on Interior and Insular Affairs, Commission Print, 302 p.

1670. Ulrich, G.E., 1963, Petrology and structure of the Porcupine Mountain area, Summit County, Colorado: Boulder, University of Colorado, Ph.D. dissertation, $168 \mathrm{p}$.

1671. Untermann, G.E., 1969, Popular guide to the geology of Dinosaur National Monument: Dinosaur, Colo., Dinosaur Nature Association, $126 \mathrm{p}$.

1672. Untermann, G.E., 1969, Geology of the Uinta Mountain area, UtahColoardo, in Geologic guidebook of the Uinta Mountains--Utah's Maverick Range, Intermountain Association of Geologists, 16 th annual field conference, 1969: [Salt Lake City?], Intermountain Association of Geologists and Utah Geological Survey, p. 79-86.

1673. Untermann, G.E., and Untermann, B.R., 1942, Geology of Green and Yampa River canyons and vicinity, Dinosaur National Monument, Utah and Colorado: American Association of Petroleum Geologists Bulletin, v. 33, no. 5, p. 683-694. 
1674. Untermann, G.E., and Untermann, B.R., 1953, Geology of the Uinta Mountain area, Utah, Colorado, in 6th annual field conference, northeastern Utah: Salt Lake City, Society of Vertebrate Paleontology, p. $1-12$.

1675. Untermann, G.E., and Untermann, B.R., 1954, Geology of Dinosaur National Monument and vicinity, Utah, Colorado: Utah Geological and Mineralogical Survey Bulletin 42, $228 \mathrm{p}$.

1676. Untermann, G.E., and Untermann, B.R., 1955, Geology of the eastern end of the Uinta Mountains, Utah, Colorado, in Ritzma, H.R., and Oriel, S.S., eds., Guidebook to the geology of northwest Colorado, Intermountain Association of Petroleum Geologists, 6th annual field conference, and Rocky Mountain Association of Geologists annual field conference, 1955: Salt Lake City, Intermountain Association of Petroleum Geologists, p. $18-20$.

1677. Upton, R.A., 1958, Pennsylvanian section at Juniper Mountain, Moffat County, Colorado, in Curtis, B.F., ed., Symposium on Pennsylvanian rocks of Colorado and adjacent areas, 1958: Denver, Rocky Mountain Association of Geologists, p. 99-102.

1678. Urbani, F., and Blackburn, W.H., 1974, Investigations in the basement rocks of Gunnison County, Colorado--The igneous rocks: Neues Jahrbuch fuer Mineralogie, v. 121, no. 3, p. 272-292.

1679. Utah State University, Water Research Laboratory, 1975, Colorado River regional assessment study--Part 1, Executive summary, basin profile, and report digest; Part 2, Detailed analyses, narrative description, data, methodology, and documentation; Part 3, Area-specific water quality $*$, Part 4, Bibliography and *wt: Logan, Utah State University, various pagination.

1680. Valasek, D.W., 1986, Stratigraphy of the Ohio Creek Member of the Williams Fork Formation, Piceance Creek Gap to Rifle Gap, Garfield and Rio Blanco Counties, Colorado: Golden, Colorado School of Mines, Master's thesis, $126 \mathrm{p}$.

1681. Valasek, D.W., 1987, Detailed stratigraphy of the Upper Cretaceous Ohio Creek Member of the Williams Fork Formation, Rifle, Colorado [abs.]: Geological Society of America Abstracts with Programs, v. 19, no. 5, p. 339.

1682. Van Liew, W.P., and Gesink, M.L., 1985, Preliminary assessment of the ground-water resources of the alluvial aquifer, White River valley, Rio Blanco County, Colorado: U.S. Geological Survey Water-Resources Investigations Report $84-4307,82 \mathrm{p}$.

1683. Vanderwilt, J.W., 1932, Preliminary geologic notes on Galena Mountain, a part of Snowmass Mountain area, Colorado: [Denver?], Colorado Science Society Proceedings, v. 13, no. 1, p. 3-18.

1684. Vanderwilt, J.W., 1935, Stratigraphy of Pennsylvanian Hermosa Formation in Elk Mountains, Gunnison County, Colorado: American Association of Petroleum Geologists Bulletin, v. 19, no. 11, p. 1668-1677.

1685. Vanderwilt, J.W., 1935, Revision of structure and stratigraphy of the Aspen district, Colorado, and its bearing on the ore deposits: Economic Geology, v. 30, no. 3, p. 223-241.

1686. Vanderwilt, J.W., 1937, Geology and mineral deposits of the Snowmass Mountain area, Gunnison County, Colorado: U.S. Geological Survey Bulletin 884, $184 \mathrm{p}$.

1687. Vanderwilt, J.W., 1947, Geology and mineral deposits of the Snowmass Mountain area, Gunnison County, in Mineral resources of Colorado: Denver, Mineral Resources Board, p. 446-451. 
1688. Vanderwilt, J.W., 1947, Aspen and Roaring Fork valley, in Guidebook of field conference in central Colorado, June 16, 17, 18, and 19, 1947: Denver, Rocky Mountain Association of Geologists, p. 63.

1689. Vanderwilt, J.W., 1947, Glenwood Canyon, in Guidebook of field conference in central Colorado, June 16,17, 18, and 19, 1947: Denver, Rocky Mountain Association of Geologists, p. 61-62.

1690. Vanderwilt, J.W., 1953, An outline of the geology seen by the conference, in Guidebook of field conference in northwestern Colorado, May 14-16, 1953: Denver, Rocky Mountain Association of Geologists, p. i-iii.

1691. Vanderwilt, J.W., and Fuller, H.C., 1935, Correlation of Colorado Yule marble and other early Paleozoic formations on Yule Creek, Gunnison County, Colorado: Denver, Colorado Scientific Society Proceedings, v. 13, no. 7, p. 439-464.

1692. Vanderwilt, J.W., and Koschmann, A.H., 1932, Geology of the Independence Pass district, Colorado: U.S. Geological Survey Mimeographed Report, $10 \mathrm{p}$.

1693. Varnes, D.J., 1944, Preliminary report on the geology of a part of the Rico Dome, Dolores County, Colorado: U.S. Geological Survey Special Geologic Maps, scale not listed.

1694. Varnes, D.J., 1948, Geology and ore deposits of the south Silverton area, San Juan County, Colorado: [Denver?], Colorado Mining Association, $12 \mathrm{p}$.

1695. Varnes, D.J., 1963, Geology and ore deposits of the South Silverton mining area, San Juan County, Colorado: U.S. Geological Survey Professional Paper 378-A, p. A1-A56.

1696. Verbeek, E.R., and Grout, M.A., 1987, Systematic joints within oil shales and associated rocks of the Green River Formation, in Taylor, $0 . J .$, ed., Oil shale, water resources, and valuable minerals of the Piceance basin, Colorado--The challenge and choices of development: U.S. Geological Survey Professional Paper 1310, p. 45-55.

1697. Vhay, J.S., 1962, Geology and mineral deposits of the area south of Telluride, Colorado: U.S. Geological Survey Bulletin 1112-G, p. 209-310.

1698. Voegeli, P.T., Sr., 1963, Ground water in Colorado--Its importance during an emergency: Colorado Water Conservation Board Ground-Water Series Circular 9, $10 \mathrm{p}$.

1699. Voegeli, P.T., Sr., 1965, Ground-water resources of North Park and Middle Park, Colorado--A reconnaissance: U.S. Geological Survey Water-Supply Paper 1809-G, p. G1-G54.

1700. Voegeli, P.T., Sr., 1969, Geology and hydrology of the Project Rulison exploratory hole, Garfield County, Colorado: U.S. Geological Survey Open-File Report, $17 \mathrm{p}$.

1701. Voegeli, P.T., Sr., and Claassen, H.C., 1971, Radiochemical analyses of water from selected streams, wells, springs, and precipitation collected prior to reentry drilling, Project Rulison: U.S. Geological Survey Open-File Report 71-312, 15 p.

1702. Voegeli, P.T., Sr., West, S.W., and Cordes, E.H., 1970, Geohydrology, Project Rulison, Garfield County, Colorado: U.S. Geological Survey Open-File Report, $52 \mathrm{p}$.

1703. Vogel, J.D., 1957, Klondike Ridge, Colorado: U.S. Geological Survey Trace Element Investigations Report TEI-700, p. 140.

1704. Waddington, R.E., 1982, White River basin oil shale water assessment, in Kilpatrick, Fritz, ed., Proceedings of the conference on water and energy technical and policy issues: New York, American Society of Civil Engineers, p. 334-339. 
1705. Wadleigh, R.F., Jr., and Ward, J.A., 1985, Carbonate-anhydrite facies determination by quantitative seismic stratigraphy in Paradox basin [abs.?]: American Association of Petroleum Geologists Bulletin, v. 69, no. 2 , p. 314.

1706. Waechter, N.B., and Johnson, W.E., 1985, Pennsylvanian-Permian block faulting in subsurface of Piceance basin, Colorado [abs.?]: American Association of Petroleum Geologists Bulletin, v. 69, no. 5, p. 869.

1707. Waechter, N.B., and Johnson, W.E., 1986, Pennsylvanian-Permian paleostructure and stratigraphy as interpreted from seismic data in the Piceance basin, northwest Colorado, in Stone, D.S., and Johnson, K.S., eds., New interpretations of northwest Colorado geology: Denver, Rocky Mountain Association of Geologists Guidebook, p. 51-64.

1708. Waegli, J.A., 1980, Geology and mineralization of the Uncle Sam Vein and surrounding area, San Juan County, Colorado: Golden, Colorado School of Mines, Master's thesis, $127 \mathrm{p}$.

1709. Waldron, F.R., Donnell, J.R., and Wright, J.C., 1951, Geology of De Beque oil-shale area, Garfield and Mesa Counties, Colorado: U.S. Geological Survey $0 i 1$ and Gas Investigations Map OM-114, 2 sheets, scale $1: 62,500$.

1710. Walker, F.K., and Bass, N.W., comps., 1951, Map of Colorado showing test wells for oil and gas, pipelines, oil and gas fields, and areas of pre-Cambrian rocks: U.S. Geological Survey $0 i 1$ and Gas Investigations Map 0M-116, 2 sheets, scale 1:500,000.

1711. Walker, T.R., 1959, Fossiliferous marine redbeds in Minturn Formation (Des Moines) near McCoy, Colorado: American Association of Petroleum Geologists Bulletin, v. 43, no. 5, p. 1069-1071.

1712. Walker, T.R., Larson, E.E., and Hoblitt, R.P., 1981, Nature and origin of hematite in the Moenkopi Formation (Triassic), Colorado Plateau--A contribution to the origin of magnetism in red beds: Journal of Geophysical Research B, v. 86, no. 1, p. 317-333.

1713. Walker, W.R., Skogerboe, G.V., Evans, R.G.j and Smith, S.W., 1977, The hydro-salinity system in the Grand Valley, in Proceedings of National Conference on Irrigation Return Flow Quality Management: Fort Collins, Colorado State University, Department of Agricultural and Chemical Engineering, p. 361-367.

1714. Wallace, A.R., and Blaskowski, M.J., 1989, Geologic map of the Mount Jackson Quadrangle and the eastern part of the Crooked Creek Pass Quadrangle, Eagle County, Colorado: U.S. Geological Survey Miscellaneous Investigations Series Map I-1909, scale 1:24,000.

1715. Wallace, A.R., Blaskowski, M.J., and Pearson, R.C., 1986, Geologic map of the Holy Cross Wilderness, Eagle, Pitkin, and Lake Counties, Colorado: U.S. Geological Survey Miscellaneous Field Studies Map MF-1841-A, scale $1: 50,000$.

1716. Wallace, R.M., 1956, Bull Canyon district, Montrose and San Miguel Counties, Colorado: U.S. Geological Survey Trace Element Investigations Report TEI-640, p. 33-35.

1717. Wallace, R.M., and Santos, E.S., 1956, Bull Canyon district, Montrose and San Miguel Counties, Colorado: U.S. Geological Survey Trace Element Investigations Report TEI-620, p. 35-39.

1718. Walton, D.S., 1963, The geology of Slater Park, Routt County, and the stratigraphy of the Lewis Shale (Upper Cretaceous), northern Routt County, Colorado: Golden, Colorado School of Mines, Master's thesis, $129 \mathrm{p}$. 
1719. Walton, D.S., and Crews, G.C., comps., 1962, Selected bibliography of the geology of northwestern Colorado, in Mott, M.R., and Amuedo, C.L., eds., Exploration for oil and gas in northwestern Colorado: Denver, Rocky Mountain Association of Geologists Guidebook, p. 173-181.

1720. Waltz, J.P., 1971, Methods of geologic evaluation of pollution potential at mountain homesites, with discussion, in Ground water: U.S. Environmental Protection Agency, Water Pollution Control Research Series 16060 GRB $08 / 71$, p. 137-143.

1721. Waltz, J.P., 1972, Methods of geologic evaluation of pollution potential at mountain homesites, with discussion, in National Ground Water Quality Symposium, Proceedings, v. 2: Ground Water, v. 10, no. 1, p. 42-49.

1722. Waltz, James, and Decker, T.L., 1981, Hydro-fracturing offers many benefits: Johnson Drillers Journal, v. 53, no. 2, p. 4-9.

1723. Wanek, A.A., 1954, Geologic map of the Mesa Verde area, Montezuma County, Colorado: U.S. Geological Survey $0 i 1$ and Gas Investigations Map OM-152, scale $1: 63,360$.

1724. Wanek, A.A., 1959, Geology and fuel resources of the Mesa Verde area, Montezuma and La Plata Counties, Colorado: U.S. Geological Survey Bulletin 1072-M, p. 667-721.

1725. Wanek, L.J., 1953, Geology of an area east of Wolcott, Eagle County, Colorado: Boulder, University of Colorado, Master's thesis, $62 \mathrm{p}$.

1726. Ward, A.N., Jr., 1966, Pre-Pennsylvanian stratigraphy of the San Juan Mountain area in southwestern Colorado: Boulder, University of Colorado, Ph.D. dissertation, $191 \mathrm{p}$.

1727. Waring, G.A., 1935, Ground water in part of southeastern Utah and southwestern Colorado: U.S. Geological Survey Open-File Report, 137 p.

1728. Waring, G.A., 1965, Thermal springs of the United States and other countries of the world--A summary revised by R.R. Blakenship and Ray Bentall: U.S. Geological Survey Professional Paper 492, 383 p.

1730. Warner, D.L., 1961, Stratigraphy of Mancos-Mesa Verde (Cretaceous) inter-tonguing, southeast Piceance basin, Colorado, and geology of a portion of the Grand Hogback, Garfield County, Colorado: Golden, Colorado School of Mines, Master's thesis, $170 \mathrm{p}$.

1731. Warner, J.W., Heimes, F.J., and Middelburg, R.F., 1985, Ground-water contribution to the salinity of the Upper Colorado River Basin: U.S. Geological Survey Water-Resources Investigations Report 84-4198, 113 p.

1732. Warner, J.W., and Sunada, D.K., 1984, Galerkin-finite element twodimensional transport model of ground water restoration for the in situ solution mining of uranium, in Groundwater hydraulics: American Geophysical Union Water Resources Monograph Series 9, p. 368-391.

1733. Warner, L.A., and Hornback, V.Q., 1971, Geology and engineering aspects of Vasquez Tunnel, Clear Creek and Grand Counties, Colorado: Association of Engineering Geologists Bulletin, v. 8, no. 2, p. 121-151.

1734. Washburne, H.D., 1872, Data on hot springs, in Statistics of mines and mining in the States and territories west of the Rocky Mountains, for the year 1870: Washington, D.C., U.S. Government Printing Office, p. 213-216.

1735. Waterman, H.D., 1955, Geology of the Ashcroft area, Pitkin County, Colorado: Golden, Colorado School of Mines, Master's thesis, $77 \mathrm{p}$.

1736. Watts, R.D., Hildenbrand, F.H., and Sass, J.H., 1984, Paradox basin, Utah--Geophysics, in Schneider, Robert, and Trask, N.J., eds., U.S. Geological Survey research in radioactive waste disposal--Fiscal year 1982: U.S. Geological Survey Water-Resources Investigations Report 84-4205, p. 41-43. 
1737. Weaver, G.D., 1974, Possible impacts of oil shale development on land resources: Journal of Soil and Water Conservation, v. 29, no. 2, p. 73-76.

1738. Weber, J.R., 1971, Structural geology of the northeastern flank of the Uinta Mountains, Moffat County, Colorado: Golden, Colorado School of Mines, Master's thesis, $68 \mathrm{p}$.

1739. Weber, J.R., 1971, Structural geology of the northeastern flank of the Uinta Mountains, Moffat County, Colorado: Mountain Geologist, v. 8, no. 4, p. 163-181.

1740. Weeks, A.D., 1951, Red and gray clay underlying ore-bearing sandstone of the Morrison Formation in western Colorado: U.S. Geological Survey [Trace Element Investigations?] Report TEM-251, $19 \mathrm{p}$.

1741. Weeks, H.J., 1925, 0il and water possibilities of parts of Delta and Mesa Counties, Colorado: Colorado Geological Survey Bulletin 28, 46 p.

1742. Weeks, J.B., 1974, Water resources of Piceance Creek basin, Colorado, in Murray, D.K., ed., Energy resources of the Piceance Creek basin, Colorado: Denver, Rocky Mountain Association of Geologists, 25th field conference, Guidebook, p. 175-180.

1743. Weeks, J.B., 1976, Ground water problems with oil shale mining in the Piceance basin: Water Spectrum, v. 8, no. 1, p. 8-14.

1744. Weeks, J.B., 1978, Digital model of ground-water flow in the Piceance basin, Rio Blanco and Garfield Counties, Colorado: U.S. Geological Survey Water-Resources Investigations Report 78-46, 108 p. [Available from National Technical Information Service, U.S. Department of Commerce, Springfield, VA 22161 as $\mathrm{PB}-284341$.]

1745. Weeks, J.B., Leavesley, G.H., Welder, F.A., and Saulnier, G.J., Jr., 1974, Simulated effects of oil-shale development on the hydrology of Piceance basin, Colorado: U.S. Geological Survey Professional Paper 908, $84 \mathrm{p}$.

1746. Weeks, J.B., and Welder, F.A., 1974, Hydrologic and geophysical data from the Piceance basin, Colorado: Colorado Water Resources Basic-Data Release 35, $121 \mathrm{p}$.

1747. Weeks, W.F., 1953, The structure and petrology of the Ute Mountains, Colorado: Urbana, University of Illinois, Master's thesis, $42 \mathrm{p}$.

1748. Weichman, B.E:, 1974, Some effects of the Rio Blanco Project nuclear detonation on the leached zone in the Parachute Creek Member of the Green River Formation, in Murray, D.K., ed., Energy resources of the Piceance Creek basin, Colorado: Denver, Rocky Mountain Association of Geologists, 25th field conference, Guidebook, p. 205-215.

1749. Weichman, B.E., 1975, Depositional history and hydrology of the Green River oil shale, Piceance Creek basin, Rio Blanco County, Colorado: Society of Mining Engineers, American Institute of Mining Engineers Transactions, v. 256, p. 272-277.

1750. Weigel, J.F., 1987, Selected hydrologic and physical properties of Mesozoic formations in the Upper Colorado River Basin in Arizona, Colorado, Utah, and Wyoming--excluding the San Juan basin: U.S. Geological Survey Water-Resources Investigations Report 86-4170, 68 p.

1751. Weigel, J.F., 1987, Selected water-level data for Mesozoic formations in the Upper Colorado River Basin, Arizona, Colorado, Utah, and Wyoming-excluding the San Juan basin: U.S. Geological Survey Open-File Report $87-397,73 \mathrm{p}$. 
1752. Weigel, J.F., 1987, Sources of hydrologic data on Mesozoic formations in the Upper Colorado River Basin and comparison of data analysis methods, in McLean, J.S., and Johnson, A.I., eds., Regional aquifer systems of the United States--Aquifers of the western mountain area: American Water Resources Association Monograph Series 14, p. 71-80.

1753. Weimer, P.C., 1982, Upper Cretaceous stratigraphy and tectonic history of the Ridgway area, northwestern San Juan Mountains, Colorado: Mountain Geologist, v. 19, no. 4, p. 91-104.

1754. Weimer, Paul, 1980, The bedrock geology of the Ridgway area, Ouray County, Colorado: Boulder, University of Colorado, Master's thesis, $91 \mathrm{p}$.

1755. Weimer, Paul, 1981, Bedrock geology of the Ridgway area, northwestern flank, San Juan Mountains, Colorado, in Epis, R.C., and Callender, J.F., eds., Western Slope, Colorado--Western Colorado and eastern Utah:

[Socorro?], New Mexico Geological Society Guidebook 32, p. 97-104.

1756. Weimer, R.J., 1970, Dakota Group (Cretaceous) stratigraphy, southern Front Range, South and Middle Parks, Colorado, in Dakota and related rocks of the Front Range: Mountain Geologist, v. 7, no. 3, p. 157-184.

1757. Weimer, R.J., and Haun, J.D., 1960, Cretaceous stratigraphy, Rocky Mountain region, in International Geologists Congress, 22d, New Delhi, India, 1960: New Delhi, International Geologists Congress Report, pt. 12 , p. 178-184.

1758. Weir, G.W., 1954, Lisbon Valley area, Utah, Colorado--Quadrangle mapping: U.S. Geological Survey Trace Element Investigations Report TEI-490, p. 33-34.

1759. Weir, G.W., 1955, Lisbon Valley area, Utah, Colorado: U.S. Geological Survey Trace Element Investigations Report TEI-590, p. 39-42.

1760. Weir, G.W., 1955, Lisbon Valley area, Utah, Colorado--Quadrangle mapping: U.S. Geological Survey Trace Element Investigations Report TEI-540, p. 50-57.

1761. Weir, G.W., Carter, W.D., Puffett, W.P., and Gualtieri, J.L., 1960, Preliminary geologic map and section of the Mount Peale 4 NE Quadrangle, San Juan County, Utah, and Montrose and San Miguel Counties, Colorado: U.S. Geological Survey Mineral Investigations Field Studies Map MF-150, scale $1: 24,000$.

1762. Weir, G.W., and Puffett, W.P., 1960, Preliminary geologic map of the Mount Peale 4 SE Quadrangle, San Juan County, Utah, and San Miguel County, Colorado: U.S. Geological Survey Mineral Investigations Field Studies Map MF-149, scale 1:24,000.

1763. Weir, G.W., and Puffett, W.P., 1981, Incomplete manuscript on stratigraphy and structural geology and uranium-vanadium and copper deposits of the Lisbon Valley area, Utah-Colorado: U.S. Geological Survey Open-File Report 81-39, 306 p.

1764. Weir, J.E., Jr., 1972, Hydraulic testing and sampling of holes RB-E-01 and RB-D-01, Project Rio Blanco, Rio Blanco County, Colorado: U.S. Geological Survey Open-File Report, 18 p.

1765. Weir, J.E., Jr., and Dinwiddie, G.A., 1973, Hydraulic testing accompanying drilling of five exploratory holes, Piceance Creek basin, Colorado: U.S. Geological Survey Open-File Report, 55 p.

1766. Weir, J.E., Jr., Maxfield, E.B., and Zimmerman, E.A., 1983, Regional hydrology of the Dolores River basin, eastern Paradox basin, Colorado and Utah: U.S. Geological Survey Water-Resources Investigations Report $83-4217,53 \mathrm{p}$. 
1767. Weiss, Emanuel, 1987, Boundary integral-equation-method modeling of a regional aquifer using geostatistics, in Proceedings of the National Water Well Association Conference on Solving Ground Water Problems with Mode1s, Denver, Feb. 10-12, 1987: Worthington, Ohio, National Water Well Association, p. 1501-1522.

1768. Weld, B.A., Iseri, K.T., and Horton, G.W., 1975, Reports and maps of the Geological Survey released only in the open files, January through April, 1974: U.S. Geological Survey Circular 706, 10 p.

1769. Welder, F.A., 1971, Groundwater reconnaissance study of selected sites in Rocky Mountain National Park and Shadow Mountain National Recreation Area: U.S. Geological Survey Open-File Report 71001, 47 p.

1770. Welder, F.A., 1987, Unconsolidated deposits of the Piceance basin, in Taylor, 0.J., ed., Oil shale, water resources, and valuable minerals of the Piceance basin, Colorado--The challenge and choices of development: U.S. Geological Survey Professional Paper 1310, p. 57-62.

1771. Welder, F.A., and Saulnier, G.J., Jr., 1978, Geohydrologic data from twenty-four test holes drilled in the Piceance basin, Rio Blanco County, Colorado, 1975-76: U.S. Geological Survey Open-File Report 78-734, $172 \mathrm{p}$.

1772. Welder, G.E., 1954, Geology of the Basalt area, Eagle and Pitkin Counties, Colorado: Boulder, University of Colorado, Master's thesis, $72 \mathrm{p}$.

1773. Welder, G.E., 1986, Plan of study for the regional aquifer-system analysis of the San Juan structural basin, New Mexico, Colorado, Arizona, and Utah: U.S. Geological Survey Water-Resources Investigations Report $85-4294,23 \mathrm{p}$.

1774. Wellborn, J.E.F., 1982, Stratigraphy of the Mesaverde Formation on the Mt. Gunnison coal property, Gunnison County, Colorado, in Southeastern Piceance basin, western Colorado: [Grand Junction, Colo.?], Grand Junction Geological Society field trip, Sept. 25-26, 1982, [Guidebook?], p. 65-67.

1775. Wengerd, S.A., 1950, Triassic rocks of northwestern New Mexico and southwestern Colorado, in Guidebook of the San Juan basin, New Mexico and Colorado, Field Conference, 1st: New Mexico Geological Society, p. $67-75$.

1776. Wengerd, S.A., and King, M.E., 1952, Geological bibliography of the Four Corners region, in Wengerd, S.A., ed., [1st] Geological symposium of the Four Corners region: [Durango, Colo.], Four Corners Geological Society, p. 133-145.

1777. Wengerd, S.A., and Lamsens, 0.R., Jr., 1952, Air photographs of the Four Corners region, in Wengerd, S.A., ed., [1st] Geological symposium of the Four Corners region: [Durango, Colo.], Four Corners Geological Society, p. 12-21.

1778. Wengerd, S.A., and Matheny, M.L., 1958, Pennsylvanian system of the Four Corners region: American Association of Petroleum Geologists Bulletin, v. 42, no. 9, p. 2048-2106.

1779. Wengerd, S.A., and Strickland, J.W., 1954, Pennsylvanian stratigraphy of the Paradox Salt basin, Four Corners region, Colorado and Utah: American Association of Petroleum Geologists Bulletin, v. 38, no. 10, p. 2157-2199.

1780. Werner, W.G., 1972, Sedimentology of the Cutler Formation (Pennsylvanian-Permian) near Gateway, Colorado, and Fisher Towers, Utah: Columbia, University of Missouri, Master's thesis, unknown pagination.

1781. Werner, W.G., 1974, Petrology of the Cutler Formation (PennsylvanianPermian) near Gateway, Colorado, and Fisher Towers, Utah: Journal of Sedimentary Petrology, v. 44, no. 2, p. 292-298. 
1782. West, M.W., 1977, The Quaternary geology, reported surface faulting and seismicity along the east flank of the Gore Range, Summit County, Colorado: Golden, Colorado School of Mines, Master's thesis, $209 \mathrm{p}$.

1783. West, M.W., 1978, Quaternary geology and reported surface faulting along east flank of Gore Range, Summit County, Colorado: Colorado School of Mines Quarterly, v. 73, no. 2, 66 p.

1784. Wetherbee, G.A., and Van Liew, W.P., 1987, Geophysically determined porosity of paleozoic rocks in the Upper Colorado River Basin, in McLean, J.S., and Johnson, A.I., eds., Regional aquifer systems of the United States--Aquifers of the western mountain area: American Water Resources Association Monograph Series 14, p. 161-169.

1785. White, C.A., 1889, On the geology and physiography of a portion of northwestern Colorado and adjacent parts of Utah and Wyoming: U.S. Geological Survey Annual Report 9 (1887-88), p. 677-712.

1786. Whitebread, D.H., 1951, Geology of the Pitkin area, Gunnison County, Colorado: Boulder, University of Colorado, Master's thesis, $35 \mathrm{p}$.

1787. Whitney, Gene, Northrop, H.R., and Hansley, P.L., 1986, The use of mineral alteration patterns and stable isotope compositions to infer a paleohydrologic regime, in Carter, L.M.H., ed., USGS research on energy resources, 1986--Program and abstracts, Second V.E. McKelvey Forum on Mineral and Energy Resources, Denver, Feb. 5-6, 1986: U.S. Geological Survey Circular 974, p. 73-74.

1788. Whitney, J.W., 1981, Surficial geologic map of the Grand Junction $1^{\circ}$ by $2^{\circ}$ Quadrangle, Colorado and Utah: U.S. Geological Survey Miscellaneous Investigations Series Map I-1289, scale 1:250,000.

1789. Whittig, L.D., Deyo, A.E., Tanji, K.K., and Higgins, C.E., 1986, Delineation and correlation of salinity to landforms and geologic formations, Upper Colorado River Basin: Davis, University of California, Department of Land, Air and Water Resources, Land, Air and Water Resources Paper 10012, July 1986, 143 p.

1790. Wiedemeier, T.H., 1988, Depositional environment of the Kremmling Sandstone Member, Pierre Shale, Middle Park, Colorado: Compass, v. 65, no. 2, p. 43-57.

1791. Wiegand, D.L., ed., 1981, Geology of the Paradox basin: Rocky Mountain Association of Geologists Field Conference, v.1981, 285 p.

1792. Williams, R.E., 1982, Statistical identification of hydraulic connections between the surface of a mountain and internal mineralized sources: Ground Water, v. 20 , no. 4, p. 466-478.

1793. Williams, R.S., Jr., and Driver, N.E., 1982, Plan for hydrologic study of an area to be surface mined for coal in northwestern Colorado: U.S. Geological Survey Open-File Report 82-874, 23 p.

1794. Williams, R.S., Jr., and Hammond, S.E., 1989, Soil-water hydrology and geochemistry of a coal spoil at a reclaimed surface mine in Routt County, Colorado: U.S. Geological Survey Water-Resources Investigations Report $86-4350,100 \mathrm{p}$.

1795. Williams, W.S., 1965, Geology of the eastern half of the Engineer Mountain Quadrangle, San Juan and La Plata Counties, Colorado: Boulder, University of Colorado, Master's thesis, $68 \mathrm{p}$.

1796. Williamson-Haffner Company, 1910, Reference map to the State of Colorado: Denver, Williamson-Haffner Company, scale not listed.

1797. Willis, J.B., 1957, Geology of the Yellowjacket Anticline area, Rio Blanco County, Colorado: Golden, Colorado School of Mines, Master's thesis, $91 \mathrm{p}$. 
1798. Willson, Kenneth, 1920, Northern part of the Tow Creek Anticline, Routt County, Colorado: Boulder, University of Colorado, Master's thesis, $50 \mathrm{p}$.

1799. Wilmarth, M.G., 1931, Correlation chart of Colorado--Tentative correlation of the named geologic units: U.S. Geological Survey Special Map, scale not listed.

1800. Wilson, H.M., Renshawe, J.H., Douglas, E.M., and Goode, R.U., 1899, Triangulation and spirit leveling: U.S. Geological Survey Annual

Report 20 (1895-99), pt. 1, p. 211-530.

1801. Wilson, H.M., Renshawe, J.H., Douglas, E.M., and Goode, R.U., 1902, Results of primary triangulation and primary traverse, fiscal year 1901-02: U.S. Geological Survey Bulletin 201, 164 p.

1802. Wilson, W.E., 1984, Paradox basin, Utah--Hydrology, in Schneider, Robert, and Trask, N.J., eds., U.S. Geological Survey research in radioactive waste disposal--Fiscal year 1982: U.S. Geological Survey Water-Resources Investigations Report 84-4205, p. 40-41.

1803. Wilson, W.L., and Livingston, A.L., 1980, Stratigraphy and coal resources of Dakota Sandstone on Sage Plain, southwest Colorado and southeast Utah, in Carter, L.M., ed., Proceedings of the Fourth symposium on the geology of Rocky Mountain coal: Colorado Geological Survey Resource Series 10, p. 69-72.

1804. Wilson, W.W., 1965, Pumping tests in Colorado: Colorado Ground-Water Series Circular 11, $361 \mathrm{p}$.

1805. Wineteer, C.B., 1986, Changes in fluvial style from the Lytle Formation (Lower Cretaceous) of Middle Park basin, north-central Colorado:

Boulder, University of Colorado, Master's thesis, $132 \mathrm{p}$.

1806. Withington, C.F., 1949, Geology of the Paradox Quadrangle, Montrose County, Colorado: Rochester, New York, University of Rochester, Master's thesis, $87 \mathrm{p}$.

1807. Withington, C.F., 1955, Gypsum Valley area, Gypsum Valley district, Montrose and San Miguel Counties, Colorado: U.S. Geological Survey Trace Element Investigations Report TEI-540, p. 35.

1808. Withington, C.F., 1955, Geology of the Paradox Quadrangle, Colorado: U.S. Geological Survey Geologic Quadrangle Map GQ-72, scale 1:24,000.

1809. Withington, C.F., 1955, Preliminary geologic map of the Paradox Quadrangle, Colorado: U.S. Geological Survey Mineral Investigations Field Studies Map MF-22, scale 1:24,000.

1810. Witter, F.M., 1899, Observations on the geology of Steamboat Springs, Colorado: Iowa Academy of Sciences Proceedings, v. 6, p. 93-98.

1811. Wittstrom, M.D., Jr., 1979, Sedimentology of the Leadville Limestone (Mississippian), northeastern Gunnison County, Colorado: Golden, Colorado School of Mines, Master's thesis, 159 p.

1812. Wolff, R.G., Bredehoeft, J.D., Keys, W.S., and Shuter, E., 1975, Stress determination by hydraulic fracturing in subsurface waste injection:

American Water Works Association Journal, v. 67, no. 9, p. 519-523.

1813. Wolff, R.G., Bredehoeft, J.D., Keys, W.S., and Shuter, E., 1974, Tectonic stress determinations, northern Piceance Creek basin, Colorado, in Murray, D.K., ed., Energy resources of the Piceance Creek basin, Colorado: Denver, Rocky Mountain Association of Geologists, 25th field conference, Guidebook, p. 193-197.

1814. Wood, G.H., Kelley, V.C., and MacAlpin, A.J., 1948, Geology of southern part of Archuleta County, Colorado: U.S. Geological Survey Oil and Gas Investigations Map OM-81, scale 1:63,360. 
1815. Wood, M.L., and Ethridge, F.G., 1987, Sedimentology of Gilbert-type fan-delta systems, Honaker Trail Formation, southwestern Colorado [abs.]: Geological Society of America Abstracts with Programs, v. 19, no. 5, p. 344 .

1816. Woodruff, E.G., 1913, Geology and petroleum resources of the De Beque oil field, Colorado, in chap. C of Contributions to economic geology, 1911--Part 2, mineral fuels: U.S. Geological Survey Bulletin 531, p. 54-68.

1817. Wright, A.F., 1979, Bibliography of geology and hydrology, San Juan basin, New Mexico, Colorado, Arizona and Utah: U.S. Geological Survey Bulletin 1481, $123 \mathrm{p}$.

1818. Wright, J.C., 1978, Four maps showing lithologic distributions of selected parts of the Jurassic San Rafael Group, Utah, Colorado, Arizona, and New Mexico: U.S. Geological Survey Open-File Report 78-572, 9 p.

1819. Wright, J.C., and Dickey, D.D., 1978, East-west cross sections of the Jurassic age San Rafael Group rocks from western Colorado to central and western Utah: U.S. Geological Survey Open-File Report 78-784, 1 sheet.

1820. Wright, J.C., and Dickey, D.D., 1978, North-south cross sections of the Jurassic San Rafael Group in Utah and western Colorado: U.S. Geological Survey Open-File Report 78-965, 1 sheet.

1821. Wright, J.C., and Dickey, D.D., 1979, Stratigraphic sections of Jurassic San Rafael Group and adjacent rocks in Rio Blanco and Garfield Counties, Colorado: U.S. Geological Survey Open-File Report 79-245, 35 p.

1822. Wright, J.C., and Dickey, D.D., 1979, Stratigraphic sections of Jurassic San Rafael Group and adjacent rocks in Routt, Park, Pitkin, and Gunnison Counties, Colorado: U.S. Geological Survey Open-File Report 79-249, $34 \mathrm{p}$.

1823. Wright, J.C., and Dickey, D.D., 1979, Stratigraphic sections of Jurassic San Rafael Group and adjacent rocks in Delta, Mesa, and Montrose Counties, Colorado: U.S. Geological Survey Open-File Report 79-250, $29 \mathrm{p}$.

1825. Wright, Robyn, Katzman, Danny, Montz, M.J., and Zech, R.S., 1989, Coastal and shallow marine cyclicity, in Hanshaw, P.M., ed., Sedimentation and basin analysis in siliciclastic rock sequences: Washington, D.C., American Geophysical Union, v. 1, 28th International Geological Congress Field Trip Guidebook T119, p. 25-33.

1826. Wright, Will, and Junge, Rahe, 1987, A combined modeling program for evaluating the cover design at a uranium mill tailings site [abs.]: Geological Society of America Abstracts with Programs, v. 19, no. 5, p. 344 .

1827. Wright, Will, and Turner, A.K., 1987, A combined modeling program for evaluating the cover design at a uranium mill tailings disposal site, in Proceedings of the Solving Ground Water Problems with Models Conference and Exposition, Denver, Colo., Feb. 10-12, 1987: Worthington, Ohio, National Water Well Association, 2 v., p. 853-869.

1828. Wyoming Geological Association, 1955, Green River basin: [Laramie?], Wyoming Geological Association Guidebook 10, $243 \mathrm{p}$.

1829. Yang, I.C., 1988, Colorado radiocarbon dates V: Radiocarbon, v. 30, no. 1, p. 41-60.

1830. Yeend, W.E., 1961, Geology of the Cimarron Ridge-Cimarron Creek area, San Juan Mountains (Montrose, Ouray, and Gunnison Counties), Colorado: Boulder, University of Colorado, Master's thesis, $69 \mathrm{p}$.

1831. Yeend, W.E., Donnell, J.R., and Smith, M.C., 1988, Geologic map of the Rulison Quadrangle, Garfield County, Colorado: U.S. Geological Survey Miscellaneous Field Studies Map MF-2060, scale 1:24,000. 
1832. Young, E.J., 1982, Uranium in Wheeler basin, Grand County, Colorado: U.S. Geological Survey Open-File Report 82-730, 31 p.

1833. Young, R.G., 1955, Sedimentary interfacies and intertonguing in the Upper Cretaceous of the Book Cliffs, Utah-Colorado: Geological Society of America Bulletin, v. 66, no. 2, p. 177-201.

1834. Young, R.G., 1959, Cretaceous deposits of the Grand Junction area, Garfield, Mesa, and Delta Counties, Colorado, in Haun, J.D., and Weimer, R.J., eds., Symposium on Cretaceous rocks of Colorado and adjacent areas--Rocky Mountain Association of Geologists, 11th field conference, Washakie, Sand Wash, and Piceance basins, 1959: Denver, Rocky Mountain Association of Geologists, p. 1-8.

1835. Young, R.G., 1960, Mancos Shale and Mesaverde Group of Palisade area, in Guide to the geology of Colorado: [Denver?], Rocky Mountain Association of Geologists, p. 85-86.

1836. Young, R.G., 1973, Cretaceous stratigraphy of the Four Corners area, in James, H.L., ed., Guidebook of Monument Valley and vicinity, Arizona and Utah: [Socorro?], New Mexico Geological Society, 24th annual field conference, p. 86-93.

1837. Young, R.G., 1982, Stratigraphy and petroleum geology of the Mesaverde Group, southeastern Piceance Creek basin, Colorado, in Southeastern Piceance basin, western Colorado: [Grand Junction, Colo.], Grand Junction Geological Society field trip, Sept. 25-26, 1982, [Guidebook?] , p. 45-54:

1838. Zabawa, L.G., 1975, Water resources in the Piceance basin, in Johnson, K.S., instructor, Energy fuels field course and workshop--Exploring the Colorado Plateau and the Rocky Mountain area of Colorado and Utah: Norman, University of Oklahoma, p. 113-127.

1839. Zabel, V.H., 1955, Geology of McElmo Dome, Montezuma County, Colorado, in Cooper, J.C., ed., Geology of parts of Paradox, Black Mesa, and San Juan basins, [1st] Four Corners field conference, 1955 [Guidebook]: [Durango, Colo.], Four Corners Geological Society, p. 132-136.

1840. Zacharakis, T.G., ed., 1981, Geothermal resources assessment of Waunita Hot Springs, Colorado: Colorado Geological Survey Special Publication, v. 16,69 p. 1843 .

1841. Zacharakis, T.G., Pearl, R.H., and Ringrose, C.D., 1983, Geothermal resource assessment of Ranger Warm Spring, Colorado: Colorado Geological Survey, Resource Series, v. 24, 65 p.

1842. Zacharakis, T.G., Ringrose, C.D., and Pearl, R.H., 1981, Geothermal resources assessment of Ouray, Colorado: Colorado Geological Survey, Resource Series, v. 15 [U.S. Department of Energy Report] (DOE/ET/28365-9), $70 \mathrm{p}$.

1843. Zapp, A.D., 1949, Geology and coal resources of the Durango area, La Plata and Montezuma Counties, Colorado: U.S. Geological Survey 0il and Gas Investigations Map OM-109, scale 1:31,680.

1844. Zapp, A.D., 1957, No. 9, White River Uplift measured section, in McKee, E.D., ed., Colorado measured sections--A Symposium: Denver, Rocky Mountain Association of Geologists, p. 46-49.

1845. Zech, R.S., 1988, Geologic map of the Fossil Ridge area, Gunnison County, Colorado: U.S. Geological Survey Miscellaneous Investigations Series Map I-1883, scale $1: 24,000$.

1846. Zeiler, R.M., 1987, Stratigraphy and palynology of Late Cretaceous and early Tertiary rocks, Tommy's Draw, Rio Blanco County, Colorado [abs.]: Geological Society of America Abstracts with Programs, v. 19, no. 5, p. 344 . 
1847. Ziemba, E.A., 1981, Rio Blanco Oil Shale Company Tract C-a, Rio Blanco County, Colorado--Summary of geology and current development, in Epis, R.C, and Callender, J.F., eds., Western Slope, Colorado--Western Colorado and eastern Utah: [Socorro?], New Mexico Geological Society Guidebook 32, p. 211-218.

1848. Zoerner, F.P., 1974, The geology of the central Elk Mountains, Colorado: Laramie, University of Wyoming, Master's thesis, $107 \mathrm{p}$. 
Aberdeen: 821

Aerial photo: 22, 123, 750, 1777

Agate Creek: 409

Aluminum: 1026

Alluvium, flood plain: 151, 826

Dissolved solids: 826

Lithologic logs: 151

Water levels: 826

Water-quality analyses: 826

Alluvium, terrace: 115, 147, 826

Dissolved solids: $115,147,826$

Lithologic logs: 115

Water levels: 115,826

Water-quality analyses: $115,147,826$

Alluvium, undifferentiated: $5,7,147,148,149,150,156,157,159,179$, $307,308,342,350,354,598,603,604,621,625,630,631,632$, $661,699,742,743,781,782,792,824,826,836,1021,1032,1106$, $1147,1341,1433,1444,1581,1682,1699,1742,1745,1766,1769$, 1770

Aquifer tests: $308,598,621,836,1032,1581,1682$

Dissolved solids: $5,7,147,148,149,157,159,307,308,342,354$, $598,621,625,630,631,632,699,742,743,781,782,792,826$, $836,1021,1032,1147,1444,1581,1682,1699,1745,1766,1769$

Drill-stem tests: 1766

Geologic sections: 7, 157, 159, 307, 308, 350, 598, 621, 625, 742, 743, $781,782,824,1032,1147,1682,1742,1745,1770$

Geophysical logs: $307,598,1745$

Hydraulic conductivity: $621,630,632,792,836,1032,1106,1682,1699$

Lithologic logs: $7,150,308,598,621,625,792,836,1032,1147,1682$, 1699,1769

Porosity: $781,782,792,1032$

Storage coefficient or specific yield: $598,621,782,836,1032,1106$, 1682,1745

Transmissivity: $7,350,598,621,625,630,836,1032,1106,1581,1682$, 1699

Water levels: $5,7,156,157,159,342,350,354,598,603,621,625$, $630,632,661,781,782,792,826,836,1032,1147,1433,1581$, $1682,1699,1745,1766,1769$

Water-quality analyses: $5,7,147,148,149,156,157,159,307,308$, $342,354,598,604,621,630,631,632,699,742,743,781,782$, $792,826,836,1021,1032,1444,1581,1682,1699,1745,1766,1769$

Anderson Mesa: 263

Animas Formation: 147, 150, 151, 157, 212, 535, 826

Dissolved solids: $147,157,212,826$

Geologic sections: 157

Lithologic logs: 150,151

Water levels: 157,826

Water-quality analyses: $147,157,212,826$

Anvil Points: 603, 604, 1248, 1436, 1533

Anvil Points Member of Green River Formation: 7, 211, 1444

Dissolved solids: 7, 211, 1444

Geologic sections: 7, 211 
Lithologic logs: 7

Transmissivity: 7

Water levels: 7

Water-quality analyses: $7,211,1444$

Archuleta County: 29, 36, 59, 64, 150, 151, 157, 212, 296, 323, 336, 338, $339,362,393,528,529,532,537,539,552,584,585,598,722$, $742,743,778,824,826,922,1025,1071,1072,1091,1102,1103$, $1122,1124,1176,1182,1291,1312,1340,1362,1379,1432,1498$, $1503,1508,1510,1511,1574,1604,1814$

Alluvium, flood plain: 151, 826

Alluvium, terrace: 826

Alluvium, undifferentiated: $150,157,598,742,743,824,826$

Animas Formation: $150,151,157,212,826$

Aquifer tests: 598

Bluff Sandstone: 585

Brushy Basin Shale Member of Morrison Formation: 29

Burro Canyon Formation: 29, 150, 151,

Cambrian System: 722, 1091

Cenozoic Erathem: 1340

Cliff House Sandstone: 150, 151, 157, 212, 532, 585, 826

Cretaceous System: 537, 539, 585, 598, 1091, 1182, 1379, 1503, 1508

Cutler Formation: 157

Dakota Group: 29, 150, 151, 157, 212, 362, 393, 585, 598, 1291, 1432

Devonian System: 1091

Dissolved solids: $64,157,212,598,722,742,743,826,922,1340$

Dolores Formation: 157

Drill-stem tests: 922

Entrada Sandstone: 585, 1071

Fruitland Formation: 150, 151, 157, 212, 537, 539, 826, 922, 1176, 1432

Geologic sections: $157,393,585,598,722,742,743,824,922,1071$, 1291,1379

Geophysical logs: $157,393,585,598,722,742,743,824,922,1071$, 91,1379

Green River Formation: 742, 743, 824, 1379

Hermosa Formation: 157, 722

Honaker Trail Formation: 722

Intrusive rocks: 157

Jurassic System: 585, 598, 1091, 1379

Kirtland Shale: 150, 151, 157, 212, 537, 826, 1176

Leadville Limestone: 742, 743, 824

Lewis Shale: $150,151,157,212,537,539,826,1176$

Lithologic logs: $150,151,598$

Mancos Shale: $29,150,151,157,212,585,598,826,1176$

Menefee Formation: $150,151,157,212,585,826,1176$

Mesaverde Group: 150, 157, 212, 339, 585, 778, 826, 1071, 1432

Mesozoic Erathem: 1340

Mississippian System: 722, 1091

Molas Formation: 157

Morrison Formation: 29, 150, 151, 157, 212, 393, 585, 1071

Niobrara Formation: 1176

Paleocene Series: 537,1508

Paleozoic Erathem: 1340, 1379

Parachute Creek Member of Green River Formation: 1379

Paradox Member of Hermosa Formation: 722 
Pennsylvanian System: 722, 1091, 1379

Permian System: 722, 1091, 1379

Pictured Cliffs Sandstone: 150, 151, 157, 532, 537, 539, 826, 1176

Pinkerton Trail Formation: 722

Point Lookout Sandstone: 150, 151, 157, 212, 585, 1176

Precambrian Erathem: 598, 1091, 1340, 1379

Quaternary System: 598, 1091, 1379

Rico Formation: 157

San Jose Formation: 150, 151, 157, 212, 826

Summerville Formation: 585

Terrace deposits: $150,151,157,598$

Tertiary System: 598, 1071, 1091, 1379, 1498, 1508

Todilto Formation: 585

Triassic System: 598, 1091, 1379

Uinta Formation: $742,743,824,1379$

Upper Cretaceous Series: 537, 1176, 1182, 1508

Upper Jurassic Series: 29

Valley-fill deposits: 826, 1071

Wanakah Formation: 150,151

Water levels: $157,362,598,826,1091,1124,1340$

Water-quality analyses: $64,157,212,393,528,552,598,722,742$, $743,826,922$

Arsenic: 551,1516

Artificial recharge: 603

Ashcroft: 1735

Aspen: $69,176,178,179,180,181,182,183,184,446,574,760,831,909$, $976,981,1050,1111,1685,1688$

Atkinson Creek: 1137

Avon: 1449

Axial: $409,701,962,1236,1237,1375$

Axial basin: 962

Aztec: 1102,1103

Azure: 1556

Bacteria: 12

Badger Wash basin: 1069

Bakers Ridge: 1600

Baldy Mountain: 474

Banty Point: 386

Bar X Wash: 658

Barcus Creek: $677,680,687,690$

Barker Creek: 1504

Basalt: 793,1772

Basin Mountain: 1186

Battle Mountain: 1048, 1352, 1499

Belden Formation: $80,411,622,630,912,992,1387,1450,1499,1707$

Dissolved solids: 630

Hydraulic conductivity: 622,630

Porosity: 622

Transmissivity: 630

Water levels: 630

Water-quality analyses: 630

Benton Shale: 631

Dissolved solids: 631

Water-quality analyses: 631 
Berthoud Pass: 1603

Bibliography: $16,17,18,19,108,110,170,294,547,640,788,866,867$, $868,869,870,872,916,918,946,1082,1197,1200,1287,1292,1719$, 1776,1817

Big Mesa: 745

Biogenic structures: $91,106,107,144,145,233,441$

Biology: 23, 25, 785, 1069

Biostratigraphy: $23,25,26,46,423,445,533,537,902,1000,1043,1101$, 1531

Bitter Creek: 504, 505

Black Cabin Gulch: 249

Black Canyon of the Gunnison: 705, 707, 710, 714, 1266

Black Ridge: 708

Black Sulphur Creek: 1516

Blue Mesa Reservoir: 115

Blue River: 786, 1513, 1514

Bluff Sandstone: 585,1301

Geologic sections: 585

Bodo Canyon: 1827

Book Cliffs: $226,502,559,570,657,1833$

Booth Creek: 1099

Borehole geophysics: 1400,1784

Bottle Pass: 1598

Bowie Shale Member of Mesaverde Formation: 405

Breckenridge: 54, 697, 987, 1359, 1586

Bridgeport: 1254

Bristol Head: 1558

Broken Hill: 926

Browns Park: 1327

Browns Park Formation: 149, 354, 468, 632, 788, 792, 1064, 1065, 1066, 1371, 1581

Aquifer tests: 1581

Dissolved solids: $149,354,632,792,1581$

Hydraulic conductivity: 632, 792

Lithologic logs: 792

Porosity: 792

Transmissivity: 1581

Water levels: $354,632,792,1581$

Water-quality analyses: $149,354,632,792,1581$

Brush Creek mining district: 592

Brush Creek Valley: 1536

Brushy Basin Shale Member of Morrison Formation: 29, 125, 1301, 1632

Brushy Point: 1413

Buckhorn Lakes: 414

Buckskin Point: 1316

Buffalo Creek: 1105

Buford: 1624

Bull Canyon: 259, 1716, 1717

Bull Fork: 684

Burns: 290 
Burro Canyon Formation: 5, 29, 30, 147, 148, 150, 151, 159, 630, 792, 836, $1032,1509,1605,1613$

Aquifer tests: 836,1032

Dissolved solids: $5,147,148,159,630,792,836,1032$

Geologic sections: 159, 1032, 1605

Hydraulic conductivity: 630,792, 836, 1032

Lithologic logs: 150, 151, 792, 836, 1032

Porosity: 792, 1032

Storage coefficient or specific yield: 836, 1032

Transmissivity: $630,836,1032$

Water levels: $5,159,630,792,836,1032$

Water-quality analyses: 5, 147, 148, 159,630,792, 836, 1032

Burrows Park: 969

Byers Peak: 523

Cactus Reservoir: 61

Calamity: $85,264,265$

Calamity Mesa: 264, 265

Calcium: 128, 282, 604

Calf Canyon: 1415

Calico Peak: 1475

Cambrian System: 6, 348, 617, 618, 619, 620, 722, 763, 1018, 1091, 1296, $1297,1425,1766,1784$

Dissolved solids: $617,722,1018,1766$

Drill-stem tests: 1766

Geologic sections: 617,618, 722, 1018

Geophysica1 logs: 620, 1784

Hydraulic conductivity: $617,619,620$

Lithologic logs: 617

Porosity: 619, 620, 1784

Transmissivity: 619

Water levels: 617, 1091, 1766

Water-quality analyses: 617, 722, 1766

Cannibal Plateau Wilderness: 1479

Carbonates: 220,604

Carbondale: 424, 426, 500, 501, 936

Carbondale coal mining area: 936

Carmel Formation: 580, 581, 1581, 1605

Aquifer tests: 1581

Dissolved solids: 1581

Geologic sections: 1605

Hydraulic conductivity: 580,581

Porosity: 580, 581

Transmissivity: 1581

Water levels: 580,1581

Water-quality analyses: 1581

Carnotite: 401,1310

Carpenter Ridge: 746

Carson Camp: 993

Carter Mine: 1435

Castle Butte Member of Leadville Limestone: 81, 408

Cation exchange: 1732

Cedar Mountain: 735

Cedar Mountain Formation: $580,581,582,947,1581$ 
Aquifer tests: 1581

Dissolved solids: 582,1581

Geologic sections: 582

Hydraulic conductivity: 580, 581, 582

Porosity: 580, 581

Storage coefficient or specific yield: 582

Transmissivity: 582,1581

Water levels: 580,1581

Water-quality analyses: 1581

Cedaredge: 461,675

Cement Creek: 1129, 1199, 1521

Cenozoic Erathem: 337, 609, 610, 817, 889, 1054, 1340, 1596

Dissolved solids: 1340

Storage coefficient or specific yield: 1340

Water levels: 1340

Cerro Summit: 413

Chaffee Formation: $408,621,699,1380,1425,1439,1524$

Aquifer tests: 621

Dissolved solids: 621,699

Geologic sections: 621

Hydraulic conductivity: 621

Lithologic logs: 621

Storage coefficient or specific yield: 621

Transmissivity: 621

Water levels: 621

Water-quality analyses: 621,699

Chair Mountain: 638, 703

Chalk Mountain: 1295

Chama Peak: 1025

Cherokee Ridge: 45

Chicken Creek: 1418

Chief Mountain: 1115

Chinle Formation: 148, 159, 445, 446, 541, 580, 581, 582, 631, 792, 1032, $1372,1581,1605$

Aquifer tests: 1032,1581

Dissolved solids: $148,159,541,582,631,792,1032,1581$

Geologic sections: $159,541,582,1032,1605$

Hydraulic conductivity: 580, 581, 582, 792, 1032

Lithologic logs: 792, 1032

Porosity: 580, 581, 792, 1032

Storage coefficient or specific yield: 582,1032

Transmissivity: $582,1032,1581$

Water levels: $159,541,580,792,1032,1581$

Water-quality analyses: $148,159,541,631,792,1032,1581$

Chlorides: 297

Chromium: 282, 656, 1578, 1580

Chromo Anticline: 338, 339

Cimarron Creek: 1830

Cimarron Ridge: 1830

Circle Dot Gulch: 686

Cisco: 861

Citadel Plateau: 844

Cliff Creek: 473

Cliff House Sandstone: 147, 150, 151, 157, 212, 532, 585, 826, 836 
Aquifer tests: 836

Dissolved solids: $147,157,212,826,836$

Geologic sections: 157,585

Hydraulic conductivity: 836

Lithologic logs: $150,151,836$

Storage coefficient or specific yield: 836

Transmissivity: 836

Water levels: $157,826,836$

Water-quality analyses: $147,157,212,826,836$

Climate: 1596

Climatology: $107,125,342,343,446,776,909,1073,1087$

Coal: $8,15,37,61,154,158,164,166,168,169,172,212,232,282,287$, $288,300,311,312,397,404,405,442,462,471,472,500,501,502$, $504,534,536,543,544,545,555,570,594,596,601,606,607,609$, $657,701,702,799,862,863,865,914,935,936,983,1003,1077,1082$, $1125,1144,1145,1162,1163,1164,1198,1236,1237,1284,1291,1337$, $1349,1368,1371,1372,1373,1374,1375,1376,1432,1437,1478,1504$, $1515,1550,1551,1620,1629,1630,1774,1794,1843$

Coalbank Pass: 37

Coalmont Formation: 1699

Dissolved solids: 1699

Hydraulic conductivity: 1699

Lithologic logs: 1699

Transmissivity: 1699

Water levels: 1699

Water-quality analyses: 1699

Cochetopa: 1093

Coffman Formation: 573

Collbran: 433

Colona: 688

Colony shale oil project: 403

Colorado National Monument: $849,850,1030,1033,1034,1547$

Colorado Plateau: $30,35,37,91,123,125,145,171,216,233,287,300$, $337,355,356,359,393,401,411,423,443,485,525,535,537$, $568,571,599,618,751,765,767,815,817,854,855,856,857$, $858,895,1077,1089,1100,1165,1166,1179,1188,1271,1284$, $1300,1302,1303,1304,1309,1313,1377,1378,1385,1388,1425$, $1458,1531,1570,1595,1596,1632,1657,1680,1707,1712,1767$, 1787

Geohydrology: $355,393,525,599,618,751,1089,1271,1595,1596$

Geologic map: 401

Geologic sections: 393,618

Geology: $30,35,37,123,125,145,171,216,233,287,300,337,355$, $359,411,423,443,525,535,568,571,751,765,767,817,895$, $1165,1166,1179,1284,1300,1303,1304,1385,1388,1425,1458$, $1531,1570,1632,1657,1680,1707,1712,1787$

Geomorphology: $359,599,1300,1657$

Hydrology: $355,525,599,618,1271,1595,1596,1767,1787$

Model: $91,485,525,1165,1377,1767$

Organics: $287,1284,1632$

Stratigraphy: $30,35,37,125,171,287,337,359,411,423,485,535$, $537,571,618,815,817,895,1077,1100,1165,1166,1179,1284$, $1300,1302,1303,1313,1385,1425,1531,1632,1680,1707,1787$

Tectonics: $337,411,535,767,895,1302,1425,1570,1707$

Water-quality analyses: 393 
Colorado River: $282,307,308,344,412,447,448,497,526,580,581,582$, $602,619,620,621,622,764,766,828,829,852,972,1018,1076,1145$, $1174,1312,1327,1338,1340,1341,1389,1426,1433,1515,1594,1597$, $1599,1605,1612,1661,1662,1679,1713,1731,1750,1751,1752,1767$, 1784,1789

Colorado River Compact: 1661

Compressibility: 1148

Conejos County: 64, 296, 323, 528, 722, 742, 743, 824, 1025, 1091, 1102, $1103,1124,1291,1312,1340,1365,1366,1379,1432$

Alluvium, undifferentiated: $742,743,824$

Cambrian System: 722, 1091

Cenozoic Erathem: 1340

Cretaceous System: 1091, 1379

Dakota Group: 1291,1432

Devonian System: 1091

Dissolved solids: $64,722,742,743,1340$

Fruitland Formation: 1432

Geologic sections: $722,742,743,824,1291,1379$

Geophysical logs: $722,742,743,824,1291,1379$

Glacial deposits: 1365,1366

Green River Formation: 742, 743, 824, 1379

Hermosa Formation: 722

Honaker Trail Formation: 722

Jurassic System: 1091, 1379

Leadville Limestone: $742,743,824$

Mesaverde Group: 1432

Mesozoic Erathem: 1340

Mississippian System: 722, 1091

Paleozoic Erathem: 1340, 1379

Parachute Creek Member of Green River Formation: 1379

Paradox Member of Hermosa Formation: 722

Pennsylvanian System: 722, 1091, 1379

Permian System: 722, 1091, 1379

Pinkerton Trail Formation: 722

Precambrian Erathem: 1091, 1340, 1379

Quaternary System: 1091, 1379

Tertiary System: 1091, 1379

Triassic System: 1091, 1379

Uinta Formation: $742,743,824,1379$

Water levels: $1091,1124,1340$

Water-quality analyses: $64,528,722,742,743$

Copper: 1516,1763

Corcoran: 1038

Corcoran Member of Price River Formation: 405

Corral Peak Anticline: 32

Cortez: $321,493,739$

Cottonwood Creek Valley: 1087

Cottonwood Wash: 617

Courthouse Mountain: 416

Cow Creek: 1423

Cozzette: 1038

Cozzette Member of Price River Formation: 405, 502, 1082

Craig: $46,167,328,390,832,864,1084,1344,1642,1643$

Crater Creek: 341 
Creede Formation: 76,113

Crescent Junction: 1183

Crested Butte: 69, 513,609,630, 988,989, 1014, 1096, 1401, 1452

Cretaceous System: 6, 30, 95, 131, 220, 287, 288, 300, 311, 412, 485, 498, $526,533,534,536,537,538,539,559,570,580,581,582,585$, $598,610,617,695,735,787,804,834,891,892,893,899,903$, $915,949,961,973,999,1000,1005,1006,1007,1008,1009,1010$, $1028,1039,1043,1081,1082,1083,1091,1100,1101,1125,1180$, $1181,1182,1211,1222,1229,1230,1231,1284,1300,1367,1371$, $1372,1379,1420,1423,1481,1503,1507,1508,1542,1543,1601$, $1680,1730,1731,1741,1756,1757,1766,1790,1805,1825,1834$, 1836,1846

Aquifer tests: 598

Dissolved solids: $582,598,617,1731,1766$

Drill-stem tests: 1766

Geologic sections: $582,585,598,617,1379,1741$

Geophysical logs: 598

Hydraulic conductivity: $580,581,582,617$

Lithologic logs: 598, 617, 1741

Porosity: 580, 581

Storage coefficient or specific yield: 582,598

Transmissivity: 582,598

Water levels: $580,598,617,1091,1766$

Water-quality analyses: $598,617,1731,1766$

Crooked Creek Pass: 1714

Cross Creek: 1499

Cross Mountain: 923, 924, 1193

Crystal Valley: 530

Crystalline rocks: 97, 563

Cumberland Pass: 1623

Cunningham Gulch: 78

Curecanti Recreation Area: 115

Curtis Formation: $580,792,1386,1581$

Aquifer tests: 1581

Dissolved solids: 792,1581

Hydraulic conductivity: 580, 792

Lithologic logs: 792

Porosity: 580,792

Transmissivity: 1581

Water levels: $580,792,1581$

Water-quality analyses: 792,1581

Cutler Formation: $37,147,157,622,775,815,1073,1505,1780,1781$

Dissolved solids: 147,157

Geologic sections: 157,775

Geophysical logs: 775

Hydraulic conductivity: 622

Porosity: 622

Water levels: 157

Water-quality analyses: 147,157

Cutoff Gulch: 681

Dakota Group: 5, 29, 30, 116, 141, 147, 148, 150, 151, 157, 159, 212, 288, $362,393,485,504,506,580,581,582,585,598,630,631,699$, $735,792,836,917,947,961,966,1032,1042,1147,1231,1291$, $1432,1452,1509,1581,1601,1605,1613,1741,1756,1803$ 
Aquifer tests: $598,836,1032,1581$

Dissolved solids: $5,116,147,148,157,159,212,582,598,630,631$, $699,792,836,1032,1147,1581$

Geologic sections: $157,159,393,582,585,598,1032,1147,1291,1605$, 1741

Geophysical logs: 598

Hydraulic conductivity: $580,581,582,630,792,836,1032,1291$

Lithologic logs: 150, 151, 598, 792, 836, 1032, 1147, 1741

Porosity: $580,581,792,1032$

Storage coefficient or specific yield: $582,598,836,1032,1291$

Transmissivity: $582,598,630,836,1032,1291,1581$

Water levels: $5,157,159,362,580,598,630,792,836,1032,1147$, 1581

Water-quality analyses: $5,147,148,157,159,212,393,598,630,631$, $699,792,836,1032,1581$

Danforth Hills: $646,797,1198,1236,1371,1372,1373,1374,1375,1376$

Darcy's law: 50, 1826, 1827

Data processing: $48,49,361,586,975,1004,1005,1008,1010,1026,1070$, $1341,1495,1615,1827,1829$

Davis Canyon: 1278

Davis Mesa: 266, 279

De Beque: $286,427,758,877,900,1709,1816$

Deadhorse Creek: 1627

Delta: 502,1108

Delta County: $5,64,116,156,159,217,248,250,282,325,327,329,461$, $462,471,472,500,501,502,503,528,570,580,581,582,588$, $618,619,620,621,622,641,668,675,676,708,740,741,742$, $743,757,824,890,893,913,914,919,920,1018,1091,1108,1124$, $1147,1291,1312,1340,1379,1597,1599,1653,1654,1655,1707$, $1731,1741,1750,1751,1784,1788,1823,1834,1837$

Alluvium, undifferentiated: $5,156,159,621,742,743,824,1147$

Aquifer tests: 621

Belden Formation: 622, 1707

Burro Canyon Formation: 5, 159

Cambrian System: 618,619,620, 1018, 1091, 1784

Carmel Formation: 580,581

Cedar Mountain Formation: $580,581,582$

Cenozoic Erathem: 1340

Chaffee Formation: 621

Chinle Formation: 159, 580, 581, 582

Cozzette Member of Price River Formation: 502

Cretaceous System: 570, 580, 581, 582, 893, 1091, 1379, 1731, 1741, 1834

Curtis Formation: 580

Cutler Formation: 622

Dakota Group: 5, 116, 159, 580, 581, 582, 1147, 1291, 1741

Devonian System: 618, 619, 620,621, 1018, 1091, 1784

Dissolved solids: $5,64,116,159,282,582,621,742,743,1018,1147$, 1340,1731

Drill-stem tests: 1599

Dyer Dolomite Member of Chaffee Formation: 621

Eagle Valley Evaporite or Formation: 622, 1707

Elbert Formation: 622

Entrada Sandstone: 116, 159, 580, 581

Eocene Series: 893 
Geologic sections: 159, 582, 618, 621, 742, 743, 824, 1018, 1147, 1291, 1379,1741

Geophysical logs: 159, 582, 618, 621, 742, 743, 824, 1018, 1147, 1291, 1379,1741

Gilman Sandstone: 621

Glen Canyon Group: 116, 580, 581, 582

Green River Formation: 5, 116, 159, 282, 742, 743, 824, 1379

Hermosa Formation: 622

Honaker Trail Formation: 622

Ignacio Quartzite: 622

Intrusive rocks: 5

Jurassic System: 580, 581, 582, 1091, 1379, 1731, 1741, 1823

Kayenta Formation: 159,580

Leadville Limestone: $116,621,622,742,743,824$

Lithologic logs: $621,1147,1741$

Lodore Formation: 622

Madison Limestone: 621,622

Mancos Shale: 5, 159, 282, 580, 581, 582, 1147, 1741

Maroon Formation: 622, 1707

Mesaverde Group: 5, 116, 156, 159, 282, 501, 502, 580, 581, 582, 893, 1741,1837

Mesozoic Erathem: 580, 581, 582, 1340, 1597, 1599, 1750, 1751

Minturn Formation: 622, 1707

Mississippian System: 618, 619,620,621, 1018, 1091, 1731, 1784

Moenkopi Formation: $580,581,582$

Molas Formation: 622

Morgan Formation: 622, 1707

Morrison Formation: 5, 159, 580, 581, 582, 1147

Navajo Sandstone: 580

Ordovician System: $618,619,620,1018,1784$

Ouray Limestone: 622

Paleozoic Erathem: 618, 619, 620, 622, 1018, 1340, 1379, 1597, 1599, 1784

Paonia Shale Member of Mesaverde Formation: 1741

Parachute Creek Member of Green River Formation: 5, 1379

Paradox Member of Hermosa Formation: 622

Park City Formation: 622

Pennsylvanian System: 618,619,620,622, 1018, 1091, 1379, 1707, 1731, 1784

Permian System: 618,619,620,622, 1018, 1091, 1379, 1707, 1731, 1784

Pinkerton Trail Formation: 622

Precambrian Erathem: 159, 248, 1018, 1091, 1340, 1379, 1731

Price River Formation: 502

Quaternary System: 156, 282, 1091, 1379, 1731, 1741

Rico Formation: 622

Rollins Sandstone Member of Mesaverde Formation: 1741

San Rafael Group: 582, 1823

Sawatch Sandstone Formation: 622, 1784

Silurian System: 619, 1018

State Bridge Formation: 622

Summerville Formation: 580

Sundance Formation: 580

Tertiary System: 893, 1091, 1379, 1597, 1599, 1731, 1741

Triassic System: 580, 581, 582, 1091, 1379, 1731, 1741 
Uinta Formation: $5,159,742,743,824,1379$

Uinta Mountain Group: 622

Upper Cretaceous Series: 501, 570, 890, 893

Valley-fill deposits: 116

Wanakah Formation: 159

Wasatch Formation: $5,156,159,1741$

Water levels: 5, 156, 159, 580, 621, 1091, 1124, 1147, 1340, 1751

Water-quality analyses: $5,64,156,159,282,528,621,742,743,1731$

Weber Sandstone: 622,1707

Wingate Sandstone: $116,159,580$

Depositional environment: $653,950,951,1067$

Desert Creek: 91, 233

Desert Gulch: 884

Deuterium: 393

Devils Hole Gulch: 1374,1375

Devonian System: $6,348,617,618,619,620,621,730,1018,1091,1425$, $1524,1614,1765,1784$

Aquifer tests: 621

Dissolved solids: $617,621,1018,1766$

Drill-stem tests: 1766

Geologic sections: $617,618,621,1018$

Geophysical logs: 620,1784

Hydraulic conductivity: $617,619,620,621$

Lithologic logs: 617,621

Porosity: 619, 620, 1784

Storage coefficient or specific yield: 621

Transmissivity: 619,621

Water levels: 617, 621, 1091, 1766

Water-quality analyses: $617,621,1766$

Dewatering: 55, 1072

Dewey Bridge: 1246,1255

Diagenesis: $106,124,144,145,233,340,408,723,724,725,800,950,951$, $956,1127,1296,1297,144,725,800$

Dillon: $90,1015,1443$

Dinosaur National Monument: 102, 125, 589, 720, 1174, 1555, 1581, 1671, 1673, 1675

Divide Creek Anticline: 998

Dockum Group: 446

Dolomitization: 408,800

Dolores County: 4, 6, 51, 53, 64, 204, 272, 273, 321, 323, 381, 383, 525, $528,529,554,558,580,581,582,619,620,622,669,722,742$, $743,775,824,960,1018,1035,1091,1124,1138,1139,1165,1291$, $1312,1333,1334,1335,1340,1379,1432,1475,1484,1485,1486$, $1487,1489,1490,1491,1597,1599,1604,1605,1693,1731,1736$, $1750,1751,1766,1784,1802$

Alluvium, undifferentiated: $742,743,824,1766$

Belden Formation: 622

Burro Canyon Formation: 1605

Cambrian System: 6, 619,620, 722, 1018, 1091, 1766, 1784

Carmel Formation: 580, 581, 1605

Cedar Mountain Formation: $580,581,582$

Cenozoic Erathem: 1340

Chinle Formation: $580,581,582,1605$

Cretaceous System: 6,580,581, 582, 1091, 1379, 1731, 1766 
Curtis Formation: 580

Cutler Formation: 622, 775

Dakota Group: $580,581,582,1291,1432,1605$

Devonian System: $6,619,620,1018,1091,1766,1784$

Dissolved solids: $4,64,582,722,742,743,960,1018,1340,1731,1766$

Drill-stem tests: 1599,1766

Eagle Valley Evaporite or Formation: 622

Elbert Formation: 6, 622, 1766

Entrada Sandstone: $580,581,1605$

Fruitland Formation: 1432

Geologic sections: $582,722,742,743,775,824,960,1018,1291,1379$, 1605

Geophysical logs: $582,722,742,743,775,824,960,1018,1291,1379$, 1605

Glen Canyon Group: $580,581,582,1165$

Green River Formation: 742, 743, 824, 1379

Hermosa Formation: 622, 722, 775, 1766

Honaker Trail Formation: 622, 722, 775

Ignacio Quartzite: 622

Junction Creek Sandstone: 1605

Jurassic System: 6, 580, 581, 582, 1091, 1165, 1379, 1731, 1766

Kayenta Formation: $580,1165,1605$

Leadville Limestone: 6, 622, 742, 743, 824, 1766

Lodore Formation: 622

Madison Limestone:- 622

Mancos Shale: 580, 581, 582, 1605

Maroon Formation: 622

Mesaverde Group: $580,581,582,1432$

Mesozoic Erathem: 580, 581, 582, 1340, 1597, 1599, 1750, 1751

Minturn Formation: 622

Mississippian System: 6, 619,620, 722, 1018, 1091, 1731, 1766, 1784

Moenkopi Formation: $580,581,582$

Molas Formation: 622,775

Morgan Formation: 622

Morrison Formation: $580,581,582,1605$

Navajo Sandstone: 580, 1605

Ordovician System: $619,620,1018,1784$

Ouray Limestone: $6,622,1766$

Paleozoic Erathem: 619, 620,622, 1018, 1340, 1379, 1597, 1599, 1784

Parachute Creek Member of Green River Formation: 1379

Paradox Member of Hermosa Formation: 622, 722, 775, 1766

Park City Formation: 622

Pennsylvanian System: 6, 619, 620, 622, 722, 1018, 1091, 1379, 1731, 1766,1784

Permian System: 6, 619, 620,622, 722, 1018, 1091, 1379, 1731, 1766, 1784

Pinkerton Trail Formation: 622, 722, 775

Precambrian Erathem: 6, 1018, 1091, 1340, 1379, 1731, 1766

Quaternary System: 6, 1091, 1379, 1731

Rico Formation: 622

San Rafael Group: 582

Sawatch Sandstone Formation: 622, 1784

Silurian System: 619,1018

State Bridge Formation: 622 
Summerville Formation: 580

Sundance Formation: 580

Tertiary System: 6, 1091, 1379, 1597, 1599, 1731, 1766

Triassic System: 6, 580, 581, 582, 1091, 1379, 1731, 1766

Uinta Formation: $742,743,824,1379$

Uinta Mountain Group: 622

Wanakah Formation: 1605

Water levels: 4, 580, 1091, 1124, 1340, 1751, 1766

Water-quality analyses: $4,64,528,722,742,743,960,1731,1766$

Weber Sandstone: 622

Wingate Sandstone: 580, 1605

Dolores Formation: 106, 107, 147, 157

Dissolved solids: 147,157

Geologic sections: 157

Water levels: 157

Water-quality analyses: 147,157

Dolores Peak: 51, 204

Dolores River: 852, 1165, 1667, 1766

Dolores River basin: 1667, 1766

Dolores River Canyon: 1165

Dotsero: $75,1076,1397$

Dotsero Formation: 1425

Dotsero Springs: 1076

Doughty Springs: 740

Douglas Arch: 1230

Douglas Creek Arch: 23, 485, 571, 895, 902, 932, 1846

Douglas Creek Member of Green River Formation: 7, 211, 302, 342, 352, 780, $781,782,886,1020,1021,1444$

Aquifer tests: 352

Dissolved solids: 7, 211, 342, 352, 780, 781, 782, 1020, 1021, 1444

Drill-stem tests: 780

Geologic sections: 7, 211, 780, 781, 782

Geophysical logs: 780

Lithologic logs: 7, 352, 780

Porosity: 781,782

Storage coefficient or specific yield: 782

Transmissivity: $7,352,780$

Water levels: $7,342,352,781,782$

Water-quality analyses: 7, 211, 342, 352, 780,781, 782, 1020, 1021, 1444

Dove Creek: 554, 1165

Dowds Junction: 318

Doyleville: 1142

Dragon: 254,1467

Drawdown: 975

Drill-stem test: 1599,1700

Dry Creek basin: 1716,1717

Duchesne River Formation: 791,792

Dissolved solids: 791,792

Hydraulic conductivity: 792

Lithologic logs: 792

Porosity: 792

Water levels: 791, 792

Water-quality analyses: 791, 792 
Dudley Gulch Graben: 301

Dunbarella: 1451

Durango: $212,323,569,940,1003,1100,1101,1127,1284,1478,1504$, $1562,1826,1827,1843$

Dyer Dolomite Member of Chaffee Formation: 408, 621, 699, 1425, 1524

Aquifer tests: 621

Dissolved solids: 621,699

Geologic sections: 621

Hydraulic conductivity: 621

Lithologic logs: 621

Storage coefficient or specific yield: 621

Transmissivity: 621

Water levels: 621

Water-quality analyses: 621,699

Eagle: $80,87,183,247,446,631,906,907,908,909,911,912,1099,1224$, $1448,1449,1450,1451,1499,1617$

Eagle basin: 183, 446, 906, 907, 908, 909, 911, 912, 1099, 1448, 1449, 1450, 1451,1617

Geology: 183, 906, 907, 908, 909, 912, 1099, 1448, 1450, 1451

Stratigraphy: $183,446,906,907,908,909,911,912,1099,1448,1449$, 1450,1451

Tectonics: $183,1099,1450$

Eagle County: ${ }^{\prime} 64,75,81,84,86,87,90,116,118,119,148,228,229,247$, $282,290,291,299,318,325,365,439,446,500,501,511,518$, $528,530,575,576,577,580,581,582,591,592,593,614,618$, $619,620,621,622,629,631,696,699,721,730,742,743,803$, $808,824,831,873,890,908,909,910,912,1018,1048,1049,1054$, $1074,1075,1091,1094,1124,1128,1146,1173,1204,1209,1224$, $1227,1280,1291,1295,1312,1324,1340,1352,1379,1387,1389$, $1397,1448,1450,1453,1492,1496,1497,1499,1524,1546,1567$, $1597,1599,1617,1633,1634,1635,1636,1638,1639,1640,1652$, $1653,1654,1699,1701,1711,1714,1715,1725,1731,1750,1751$, 1772,1784

Alluvium, undifferentiated: $148,621,631,699,742,743,824,1699$

Aquifer tests: 621

Belden Formation: $622,912,1387,1450,1499$

Benton Shale: 631

Burro Canyon Formation: 148

Cambrian System: 618,619,620, 1018, 1091, 1784

Carmel Formation: 580, 581

Castle Butte Member of Leadville Limestone: · 81

Cedar Mountain Formation: $580,581,582$

Cenozoic Erathem: 1054, 1340

Chaffee Formation: $621,699,1524$

Chinle Formation: $148,446,580,581,582,631$

Coalmont Formation: 1699

Cretaceous System: $580,581,582,1091,1379,1731$

Curtis Formation: 580

Cutler Formation: 622

Dakota Group: $116,148,580,581,582,631,699,1291$

Devonian System: $618,619,620,621,730,1018,1091,1524,1784$

Dissolved solids: $64,116,148,282,582,621,631,699,742,743$, $1018,1340,1699,1731$

Dockum Group: 446 
Drill-stem tests: 1599

Dyer Dolomite Member of Chaffee Formation: 621, 699, 1524

Eagle Valley Evaporite or Formation: 148, 622, 631, 909, 912, 1049, $1094,1448,1450$

Elbert Formation: 622

Entrada Sandstone: $116,148,580,581,631,699$

Geologic sections: $247,582,618,621,742,743,824,1018,1291,1379$

Geophysical logs: $247,582,618,621,742,743,824,1018,1291,1379$

Gilman Sandstone: 621

Glen Canyon Group: 116, 580, 581, 582

Green River Formation: 116, 282, 742, 743, 824, 1379

Hermosa Formation: 622

Holocene Series: 1499

Honaker Trail Formation: 622

Ignacio Quartzite: 622

Jurassic System: 580, 581, 582, 1091, 1379, 1496, 1497, 1731

Kayenta Formation: 580

Leadville Limestone: $81,116,621,622,699,742,743,824,1524$

Lithologic logs: $247,621,1699$

Lodore Formation: 622

Madison Limestone: 621,622

Mancos Shale: $148,282,580,581,582$

Manitou Formation: 699,831

Maroon Formation: $148,622,631,699,909,910,912,1049,1173,1450$

Mesaverde Group: $116,148,282,501,580,581,582$

Mesozoic Erathem: 580, 581, 582, 1340, 1597, 1599, 1750, 1751

Middle Pennsylvanian Series: 1448

Minturn Formation: 118, 119, 622, 631, 699, 1049, 1173, 1450, 1499, 1617,1711

Mississippian System: $81,618,619,620,621,1018,1091,1209,1524$, 1731,1784

Moenkopi Formation: 580, 581, 582

Molas Formation: 622

Morgan Formation: 622

Morrison Formation: $148,580,581,582,699$

Navajo Sandstone: 580

Niobrara Formation: 631

Ordovician System: $618,619,620,1018,1784$

Ouray Limestone: 622

Paleozoic Erathem: 75, 228, 618, 619,620, 622, 909, 1018, 1173, 1209, $1340,1379,1524,1597,1599,1784$

Parachute Creek Member of Green River Formation: 1379

Paradox Member of Hermosa Formation: 622

Park City Formation: 622

Parting Quartzite Member of Chaffee Formation: 229, 699, 1524

Pennsylvanian System: 118, 291, 618, 619, 620, 622, 699, 803, 908, 909, $912,1018,1091,1173,1204,1379,1387,1448,1450,1499,1638$, 1731,1784

Permian System: $593,618,619,620,622,908,910,912,1018,1091$, $1173,1379,1496,1497,1731,1784$

Pierre Shale: 631

Pinkerton Trail Formation: 622

Pleistocene Series: 247,1499

Precambrian Erathem: 631, 699, 1018, 1091, 1340, 1379, 1731 
Quaternary System: 247, 282, 1091, 1379, 1499, 1731

Rico Formation: 622

Robinson Limestone Member of Minturn Formation: 1617

San Rafael Group: 582

Sawatch Sandstone Formation: 622, 699, 1784

Silurian System: 619,1018

State Bridge Formation: 148, 575, 622, 631, 909, 910

Summerville Formation: 580

Sundance Formation: 580

Terrace deposits: 699

Tertiary System: $631,1091,1379,1597,1599,1731$

Triassic System: 446, 580, 581, 582, 1091, 1379, 1496, 1497, 1731

Uinta Formation: $742,743,824,1379$

Uinta Mountain Group: 622

Upper Cretaceous Series: 501, 890

Upper Triassic Series: 446

Valley-fill deposits: 116

Wasatch Formation: 148

Water levels: 247, 580,621, 1091, 1124, 1340, 1699, 1751

Water-quality analyses: $64,148,282,528,621,631,699,742,743$, $1699,1701,1731$

Weber Sandstone: $148,622,909,1450$

Wingate Sandstone: 116,580

Eagle River: $80,87,631,1224,1499$

Eagle River Anticline: 87

Eagle River Valley: 631

Eagle Valley Evaporite or Formation: $148,411,622,631,909,911,912,1016$, $1049,1094,1098,1099,1371,1448,1449,1450,1451,1707$

Dissolved solids: 148,631

Hydraulic conductivity: 622

Porosity: 622

Water-quality analyses: 148,631

Earthquakes: 1812

Easton Gulch: $1370,1374,1375$

Echo Park: 102

Egnar: $267,268,1575$

Elbert Formation: 6, 147, 622, 1766

Dissolved solids: 147,1766

Drill-stem tests: 1766

Hydraulic conductivity: 622

Porosity: 622

Water levels: 1766

Water-quality analyses: 147, 1766

Electra Lake: 1600

Elk Mountains: $68,70,285,510,639,991,1332,1684,1848$

Elk Range: 783

Elk Springs: 465,468

Emerald Lake: 1232

Energy-resource development: 1151, 1152

Engineer Mountain: 373, 1795

Entrada Sandstone: $116,147,148,159,541,580,581,585,630,631,699$, $767,792,836,955,1032,1071,1254,1386,1452,1549,1581,1605$

Aquifer tests: $836,1032,1581$

Dissolved solids: $116,147,148,159,541,630,631,699,792,836$, 1032,1581 
Geologic sections: 159, 541, 585, 1032, 1071, 1605

Hydraulic conductivity: 580, 581, 630, 792, 836, 1032

Lithologic logs: 792, 836, 1032

Porosity: 580, 581, 792, 1032

Storage coefficient or specific yield: 836, 1032

Transmissivity: $630,836,1032,1581$

Water levels: $159,541,580,630,792,836,1032,1581$

Water-quality analyses: $147,148,159,541,630,631,699,792,836$, 1032,1581

Eocene Series: $27,28,52,398,460,547,632,683,689,883,886,889,893$, $944,1067,1114,1195,1244,1250,1421,1422,1495,1523,1525$

Dissolved solids: 632,944

Geologic sections: 398

Geophysical logs: 398

Hydraulic conductivity: 632

Lithologic logs: 398

Water levels: 632

Water-quality analyses: 632,944

ERTS-1 imagery: 1626

Escalante Forks: 668

Escalante Hills: 1327

Eureka: 190

Evacuation Creek Member of Green River Formation: 352

Aquifer tests: 352

Dissolved solids: 352

Lithologic logs: 352

Transmissivity: 352

Water levels: 352

Water-quality analyses: 352

Evaporites: 233,934

Farris Creek: 628

Farwell Mountain: 1472

Faults: $37,301,337,408,409,411,640,767,1000,1028,1452,1457,1570$, $1706,1782,1783$

Figure Four Spring: 876, 878

Fish Creek: 1476,1570

Fisher Towers: 1780,1781

Foidel Creek: 1437

Forked Gulch: 1253

Fort Union Formation: 149, 632, 787, 1000, 1532

Dissolved solids: 149,632

Hydraulic conductivity: 632

Water levels: 632

Water-quality analyses: 149,632

Fossil Ridge: 992,1845

Four Corners area: $22,38,117,348,358,417,496,534,617,796,815,929$, $966,1095,1377,1378,1585,1601,1631,1705,1776,1777,1778,1779$, 1836

Four J Rim: 1412

Fox Hills Sandstone: 787,834

Fractures: $97,123,140,301,403,1044,1696,1812,1813$

Fraser Experimental Forest: 1627

Fremont Limestone: 1425 
Front Range: 183, 409, 652, 802, 906, 911, 921, 1026, 1085, 1099, 1132, 1188, $1402,1425,1457,1756$

Frontier Formation or Frontier Sandstone Member of Mancos Shale: 1088, 1184 Fruita: 1455

Fruitland Formation: $147,150,151,157,212,288,300,533,534,536,537$, $539,826,836,922,1100,1101,1176,1432$

Aquifer tests: 836

Dissolved solids: $147,157,212,826,836,922$

Drill-stem tests: 922

Geologic sections: 157,922

Hydraulic conductivity: 836

Lithologic logs: 150, 151, 836

Storage coefficient or specific yield: 836

Transmissivity: 836

Water levels: $157,826,836$

Water-quality analyses: $147,157,212,826,836,922$

Fuel resources: $60,1019,1246,1249,1506,1706,1724$

Fulford mining district: 591, 592, 1054

Galena Mountain: 104, 1683

Garden Gulch Member of Green River Formation: 7, 211, 352, 886, 1020, 1444, 1590

Aquifer tests: 352

Dissolved solids: $7,211,352,1020,1444$

Geologic sections: 7, 211, 1590

Lithologic logs: 7, 352

Storage coefficient or specific yield: 1590

Transmissivity: 7,352

Water levels: 7,352

Water-quality analyses: $7,211,352,1020,1444$

Garfield: 122, 419, 420, 1042

Garfield County: 7, 12, 15, 64, 69, 73, 74, 116, 122, 127, 148, 162, 170, $211,226,227,228,229,246,250,256,282,286,307,308,325$, $328,340,342,343,344,390,403,404,405,419,424,425,426$, $427,431,435,436,437,438,442,446,458,459,500,502,506$, $528,530,559,570,580,581,582,588,600,603,604,618,619$, $620,621,622,632,633,649,657,658,661,681,683,684,685$, $686,694,730,735,742,743,779,780,781,782,791,792,824$, $827,832,871,874,875,876,878,882,884,885,886,887,888$, $890,892,893,894,895,897,899,903,909,912,932,936,942$, $943,944,970,974,990,998,1000,1005,1006,1007,1008,1009$, $1010,1013,1018,1020,1021,1039,1040,1041,1043,1044,1078$, $1079,1081,1082,1083,1091,1094,1124,1128,1148,1151,1194$, $1196,1201,1203,1233,1234,1244,1247,1248,1250,1253,1255$, $1256,1278,1281,1291,1308,1312,1321,1326,1339,1340,1356$, $1379,1404,1405,1413,1414,1415,1416,1436,1444,1450,1473$, $1482,1579,1590,1591,1592,1597,1599,1618,1626,1628,1642$, $1643,1653,1654,1680,1696,1700,1701,1702,1707,1709,1714$, $1730,1731,1742,1744,1745,1746,1750,1751,1770,1784,1788$, $1821,1831,1834$

Alluvium, undifferentiated: $7,148,307,308,342,603,604,621,632$, $661,742,743,781,782,792,824,1021,1444,1742,1745,1770$

Anvil Points Member of Green River Formation: 7, 211, 1444

Aquifer tests: 308,621

Belden Formation: $622,912,1450,1707$ 
Bowie Shale Member of Mesaverde Formation: 405

Browns Park Formation: 632, 792

Burro Canyon Formation: 148, 792

Cambrian System: 618,619,620, 1018, 1091, 1784

Carmel Formation: 580,581

Cedar Mountain Formation: 580, 581, 582

Cenozoic Erathem: 1340

Chaffee Formation: 621

Chinle Formation: 148, 446, 580, 581, 582, 792

Corcoran Member of Price River Formation: 405

Cozzette Member of Price River Formation: 405, 502, 1082

Cretaceous System: $559,570,580,581,582,735,892,893,899,903$, $1000,1005,1006,1007,1008,1009,1010,1039,1043,1081,1082$, $1083,1091,1379,1680,1730,1731,1834$

Curtis Formation: 580,792

Cutler Formation: 622

Dakota Group: $116,148,506,580,581,582,735,792,1291$

Devonian System: $618,619,620,621,730,1018,1091,1784$

Dissolved solids: $7,64,116,148,211,282,307,308,342,343,344$, $442,582,621,632,742,743,780,781,782,791,792,942,943$, $944,1018,1020,1021,1281,1339,1340,1444,1700,1702,1731$, 1745,1746

Dockum Group: 446

Douglas Creek Member of Green River Formation: 7, 211, 342, 780, 781; $782,886,1020,1021,1444$

Dril1-stem tests: $780,1599,1700,1702$

Duchesne River Formation: 791, 792

Dyer Dolomite Member of Chaffee Formation: 621

Eagle Valley Evaporite or Formation: 148, 622, 909, 912, 1094, 1450, 1707

Elbert Formation: 622

Entrada Sandstone: $116,148,580,581,792$

Eocene Series: $632,683,886,893,944,1244,1250$

Fort Union Formation: 632, 1000

Garden Gulch Member of Green River Formation: 7, 211, 886, 1020, 1444, 1590

Geologic sections: $7,211,307,308,403,582,618,621,742,743,780$, $781,782,824,942,943,1018,1291,1339,1379,1404,1405,1590$, $1592,1702,1742,1745,1770$

Geophysical logs: 7, 211, 307, 308, 403, 582, 618, 621, 742, 743, 780, $781,782,824,942,943,1018,1291,1339,1379,1404,1405,1590$, $1592,1702,1742,1745,1770$

Gilman Sandstone: 621

Glacial deposits: 791

Glen Canyon Group: $116,580,581,582,792$

Green River Formation: 7, 116, 211, 256, 282, 307, 308, 342, 403, 683, $742,743,779,780,781,782,792,824,886,944,1020,1021,1148$, $1196,1250,1321,1339,1379,1404,1405,1444,1590,1628,1696$, $1700,1702,1742,1745$

Hermosa Formation: 622

Honaker Trail Formation: 622

Ignacio Quartzite: 622

Iles Formation: $405,632,1043,1044,1081,1082,1083$

Jurassic System: 580, 581, 582, 1091, 1379, 1731, 1821 
Kayenta Formation: 580

Lance Formation: 632,1000

Leadville Limestone: $116,340,621,622,742,743,824,871$

Lewis Shale: 632

Lithologic logs: 7, 308, 621, 780, 792, 1339

Lodore Formation: 622

Madison Limestone: $621,622,792$

Mancos Shale: 148, 282, 506, 580, 581, 582, 632, 633, 792, 932, 1043 1730

Maroon Formation: $73,148,424,622,909,912,990,1450,1707$

Mesaverde Group: $116,148,282,405,502,506,580,581,582,632,633$, $649,792,885,893,903,1000,1005,1006,1007,1008,1009,1010$, $1039,1040,1041,1043,1044,1081,1082,1234,1339,1356,1473$, $1700,1702,1730$

Mesozoic Erathem: 580, 581, 582, 1078, 1340, 1592, 1597, 1599, 1750, 1751

Minturn Formation: $622,832,1450,1707$

Mississippian System: $340,618,619,620,621,1018,1091,1731,1784$

Moenkopi Formation: $580,581,582,792$

Molas Formation: 622

Morgan Formation: 622, 792, 1707

Morrison Formation: $148,580,581,582,792$

Navajo Sandstone: 580

Ohio Creek Formation: 1044, 1680, 1700, 1702

Ordovician System: $618,619,620,1018,1784$

Ouray Limestone: 622

Paleocene Series: 1700,1702

Paleozoic Erathem: 228, 618, 619, 620,622, 909, 1018, 1078, 1340, 1379, $1592,1597,1599,1784$

Paonia Shale Member of Mesaverde Formation: 405

Parachute Creek Member of Green River Formation: 7, 211, 307, 342, 403, $780,781,782,886,1020,1021,1379,1404,1405,1444,1590,1745$

Paradox Member of Hermosa Formation: 622

Park City Formation: 622, 792

Parting Quartzite Member of Chaffee Formation: 229

Pennsylvanian System: $618,619,620,622,832,909,912,1018,1091$, $1379,1450,1707,1731,1784$

Permian System: $618,619,620,622,912,1018,1091,1379,1707,1731$, 1784

Permian and Pennsylvanian Systems: 69

Pinkerton Trail Formation: 622

Precambrian Erathem: 1018, 1091, 1340, 1379, 1731

Price River Formation: 405, 502, 1082

Quaternary System: 282, 1091, 1339, 1379, 1700, 1702, 1731

Rico Formation: 622

Rollins Sandstone Member of Mesaverde Formation: 405, 1043, 1082

San Rafael Group: 582, 1821

Sawatch Sandstone Formation: 622, 1784

Sego Sandstone: 405

Silurian System: 619, 1018

South Canyon Creek Dolomite Member of State Bridge Formation: 73

State Bridge Formation: 148, 622, 909

Summerville Formation: 580

Sundance Formation: 580 
Terrace deposits: 661

Tertiary System: $506,559,632,885,892,893,897,899,903,944,1000$, $1091,1250,1379,1592,1597,1599,1680,1696,1731$

Triassic System: 446, 580, 581, 582, 1091, 1379, 1731

Trout Creek Sandstone Member of Iles Formation: 1081, 1082

Uinta Formation: $7,211,403,742,743,782,791,792,824,944,1020$, $1148,1250,1339,1379,1404,1405,1444,1590,1742,1745$

Uinta Mountain Group: 622, 792

Upper Cretaceous Series: 405, 506, 570, 885, 890, 892, 893, 897, 903, $1000,1005,1006,1007,1008,1009,1010,1039,1043,1044,1081$, $1083,1234,1680$

Upper Devonian Series: 227

Upper Triassic Series: 446

Valley-fill deposits: 116,632

Wasatch Formation: 7, 148, 211, 307, 403, 427, 506, 632, 779, 782, 792, $885,1000,1020,1339,1444,1680,1700,1702$

Water levels: $7,342,343,344,403,442,580,603,621,632,661,781$, $782,791,792,1091,1124,1339,1340,1702,1745,1746,1751$

Water-quality analyses: $7,64,148,211,282,307,308,342,343,344$, $2,528,604,621,632,742,743,780,781,782,791,792,942,943$, $945,1020,1021,1281,1339,1444,1700,1701,1702,1731,1745$, 1746

Weber Sandstone: 148, 424, 425, 622, 790, 792, 909, 1450, 1707

Williams Fork Formation: 405, 632, 1044, 1082, 1083, 1680

Wingate Sandstone: 116,580

Garfield Mine: 122

Gateview: 1265

Gateway: $262,483,1505,1576,1780,1781$

Geneva Creek: 1132

Geochemistry: 4, 25, 211, 215, 221, 295, 296, 393，448，463, 526, 528, 548, $552,561,564,640,645,722,727,742,743,753,765,782,926,942$, $943,945,1012,1013,1022,1026,1053,1132,1161,1213,1214,1232$ $1311,1336,1383,1395,1404,1405,1436,1444,1475,1522,1533,1577$, $1579,1618,1629,1715,1759,1760,1787,1794$

Geographic information systems: 361,1615

Geologic map indexes: 108, 110, 170,864, 867, 1133

Geologic maps:

Anderson Mesa Quadrangle: 263

Anvil Points Quadrangle: 1248

Aspen Quadrangle: 176, 178, 181

Aspen area: 184

Atkinson Creek Quadrangle: 1137

Axial Quadrangle: 1237

Aztec $1^{\circ}$ by $2^{\circ}$ Quadrangle: 1102, 1103

Banty Point Quadrangle: 386

Bar X Wash Quadrangle: 658

Barcus Creek Quadrangle: 680, 687

Barcus Creek SE Quadrangle: 677, 690

Basin Mountain Quadrangle: 1186

Baxter Pass Quadrangle: 888

Berthoud Pass Quadrangle: 1603

Big Mesa Quadrangle: 745

Bitter Creek Well Quadrangle: 504, 505

Black Cabin Gulch Quadrangle: 249 
Black Canyon of the Gunnison area: 710 Black Ridge Quadrangle: 708

Blue River area: 1513, 1514

Bonanza district: 1282

Bonanza-Dragon oil-shale area: 254

Bottle Pass Quadrangle: 1598

Bristol Head Quadrangle: 1558

Brush Creek mining district: 592

Brushy Point Quadrangle: 1413

Bryson Canyon Quadrangle: 658

Buckhorn Lakes Quadrangle: 414

Buckskin Point Quadrangle: 1316

Bull Canyon Quadrangle: 259

Bull Fork Quadrangle: 684

Byers Peak Quadrangle: 523

Cactus Reservoir Quadrangle: 61

Calamity Mesa Quadrangle: 264265

Calf Canyon Quadrangle: 1415

Cameron Pass area: 643

Cannibal Plateau wilderness roadless area:

1479

Canyon of Lodore North Quadrangle: 717

Canyon of Lodore South Quadrangle: 711

Carpenter Ridge Quadrangle: 746

Cathedral Bluffs oil-shale area: 431

Cedaredge area: 461,675

Cerro Summit Quadrangle: 413

Chair Mountain Quadrangle: 638

Chama Peak Quadrangle: 1025

Chicken Creek SW Quadrangle: 1418

Circle Dot Gulch Quadrangle: 686

Citadel Plateau Quadrangle: 844

Coach Creek NE Quadrangle: 670

Coach Creek SE Quadrangle: 671

Collbran Quadrangle: 433

Colona Quadrangle: 688

Colorado: 193, 326, 1155, 1644, 1646

Cortez $1^{\circ}$ by $2^{\circ}$ Quadrangle: 321

Cortez SW Quadrangle: 493

Courthouse Mountain Quadrangle: 416

Craig $1^{\circ}$ by $2^{\circ}$ Quadrangle: 328, 864, 1642, 1643

Craig Quadrangle: 1084

Creede Quadrangle: 1566

Crooked Creek Pass Quadrangle: 1714

Cutoff Gulch Quadrangle: 681

Danforth Hills area: 797

Davis Canyon Quadrangle: 1278

Davis Mesa Quadrangle: 266, 279

Delta Quadrangle: 502, 1108

Denver $1^{\circ}$ by $2^{\circ}$ Quadrangle: $185,186,322$

Desert Gulch Quadrangle: 884

Dillon Quadrangle: 90

Dinosaur National Monument: 720

Dolores Peak Quadrangle: 204

Doyleville SW Quadrangle: 1142 
Dragon Quadrangle: 1467

Durango $1^{\circ}$ by $2^{\circ}$ Quadrangle: 323

Durango Quadrangle: 1562

Eagle River Anticline: 87

Easton Gulch Quadrangle: 1370

Egnar Quadrangle: 267, 268

Elk Springs Quadrangle: 465

Engineer Mountain area: 373

Escalante Forks Quadrangle: 668

Farwell Mountain Quadrangle: 1472

Figure Four Spring Quadrangle: 876

Forked Gulch Quadrangle: 1253

Fossil Ridge area: 1845

Four J Rim Quadrangle: 1412

Fulford mining district: 592

Garfield Quadrangle: 419

Gateview Quadrangle: 1265

Gateway Quadrangle: 262

Gateway area: 1576

Gateway district: 483

Glenwood Springs area: 1079

Glenwood Springs Quadrangle: 74

Granby Anticline: 1442

Grand Junction $1^{\circ}$ by $2^{\circ}$ Quadrangle: 1788

Grand Junction Quadrangle: 250, 502

Grand Junction area: 1031, 1032

Grand Valley Quadrangle: 435

Gray Head Quadrangle: 205

Greasewood Gulch Quadrangle: 454

Greeley $1^{\circ}$ by $2^{\circ}$ Quadrangle: 133,324

Gunnison County: 1678

Gunnison area: 503

Gypsum Gap Quadrangle: 260

Hahns Peak Quadrangle: 1472

Hahns Peak district: 62

Hamm Canyon Quadrangle: 269, 270

Handies Peak Quadrangle: 1057, 1063

Harley Dome Quadrangle: 504, 505

Hawxhurst Creek Quadrangle: 437

Hayden Peak Quadrangle: 175

Haystack Rock Quadrangle: 716

Hells Canyon Quadrangle: 719

Henderson Ridge Quadrangle: 1416

Hermosa Peak Quadrangle: 1334

Highland Peak Quadrangle: 177

Holy Cross Quadrangle: 1639

Horse Range Mesa Quadrangle: 271

Horsefly Peak Quadrangle: 691

Hot Sulphur Springs Quadrangle: 839

Hot Sulphur Springs SE Quadrangle: 845

Hot Sulphur Springs SW Quadrangle: 841

Hotchkiss area: 676

Housetop Mountain Quadrangle: 436

Houston Gulch Quadrangle: 1261 
Howardsville Quadrangle: 1058

Ignacio Quadrangle: 59

Indian Valley Quadrangle: 1318

Indian Water Canyon Quadrangle: 1428

Iris NW Quadrangle: 747

Iris Quadrangle: 1260

Iris SE Quadrangle: 1142

Ironton Quadrangle: 194

Jefferson Quadrangle: 58

Jessup Gulch Quadrangle: 455

Jim Canyon Quadrangle: 658

Joe Davis Hill Quadrangle: 272, 273

Jones Hole Quadrangle: 712

Juanita Arch Quadrangle: 1500, 1501

Kinney Rim Quadrangle: 1419

Kline Quadrangle: 1463

Kremmling Quadrangle: 842

La Plata Quadrangle: 384, 1350

La Plata mining district: 475

La Sal Creek area: 241

Lake City area: 833

Lake City caldera area: 1024

Lay Quadrangle: 172

Lay SE Quadrangle: 168,169

Leadville $1^{\circ}$ by $2^{\circ}$ Quadrangle: 325, 1653, 1654

Lisbon Valley area: 1758

Little Cone Quadrangle: 208

Log Hill Mesa area: 682

Lone Mountain Quadrangle: 1135

Long Point Quadrangle: 874

Loveland Pass Quadrangle: 523

Marble Quadrangle: 611

Marcellina Mountain Quadrangle: 612

Maroon Bells Quadrangle: 174

Maudlin Gulch area: 797

Maybell Quadrangle: 1136

Maybel1-Lay area: 93, 94

McCarthy Gulch Quadrangle: 1256

McCoy area: 439

Meeker $1^{\circ}$ by $2^{\circ}$ Quadrangle: 170

Mellen Hill Quadrangle: 387

Mesa Quadrangle: 432

Mesa Verde area: 1723

Middle Dry Fork Quadrangle: 882

Middle Park: 1637

Moab $1^{\circ}$ by $2^{\circ}$ Quadrangle: 327

Molina Quadrangle: 434

Monarch Valley: 837

Montezuma Quadrangle: 1047

Montrose $1^{\circ}$ by $2^{\circ}$ Quadrangle: 329, 1655

Montrose Quadrangle: 641, 1560

Moqui SE Quadrangle: 494

Moqui SW Quadrangle: 805

Mount Blaine Quadrangle: 685 
Mount Harvard Quadrangle: 146

Mount Jackson Quadrangle: 1714

Mount Lincoln Quadrangle: 1640

Mount Peale 1 NE Quadrangle: 245

Mount Peale 1 SE Quadrangle: 243

Mount Peale 4 NE Quadrangle: 1761, 1762

Mount Peale-1 Quadrangle: 664

Mount Peale-16 Quadrangle: 667

Mount Peale-8 Quadrangle: 666

Mount Peale-9 Quadrangle: 665

Mount Richthofen Quadrangle: 1242

Mount Wils on Quadrangle: 152, 153

Mt. Axtell Quadrangle: 610

Naturita NW Quadrangle: 274

Naval 0il Shale Reserves 1 and 3: 459

Needle Mountains Quadrangle: 375

Needle Mountains: 57

Ninemile Gap Quadrangle: 1237

No-Name Ridge Quadrangle: 1251

North Mamm Peak Quadrangle: 438

northwestern Colorado: 1065, 1239

Norwood-1 Quadrangle: 1109

Oh-Be-Joyful Quadrangle: 613

Ouray Quadrangle: 1056, 1663

Ouray mining district: 191, 1062

Pagosa Springs Quadrangle: 59

Pahlone Peak Quadrangle: 1262

Paonia area: 462, 503, 913

Paradox basin: 349

Paradox Quadrangle: 1808, 1809

Park Range: 1527, 1528

Pine Mountain Quadrangle: 261

Placerville Quadrangle: 206

Platoro-Summitville mining district: 1283

Plug Hat Rock Quadrangle: 1429

Powderhorn Quadrangle: 748

Powderhorn Wilderness Study Area: 1479

Quartz Creek pegmatite district: 1540

Ragged Mountain area: 798

Rangely NE Quadrangle: 607

Rangely Quadrangle: 388

Rangely oil district: 597

Razor Creek Dome Quadrangle: 1268

Razorback Ridge Quadrangle: 1414

Red Creek Ranch Quadrangle: 1411

Red Mesa area: 60

Rico Quadrangle: 1335

Ridgway Quadrangle: 692

Rio Blanco Quadrangle: 1247

Roan Plateau area: 694

Roc Creek Quadrangle: 1502

Rock School Quadrangle: 456

Rough Gulch Quadrangle: 679

Routt County: 1170 
Rudolph Hill Quadrangle: 1259

Ruedi Quadrangle: 577

Rulison Quadrangle: 1831

Saddle Quadrangle, see "The Saddle"

Sage Plain area: 812

Sagebrush Hill Quadrangle: 429

San Arroyo Ridge Quadrangle: 658

San Juan basin: 349

San Juan Mountains: 199, 200, 201, 202

San Juan region: 379, 994

Sawmill Mountain Quadrangle: 1369, 1371

Sawtooth Mountain Quadrangle: 1267

Scrivner Butte Quadrangle: 1417

Segar Mountain Quadrangle: 1243

Sentinel Peak NE Quadrangle: 495

Sentinel Peak NW Quadrangle: 489

Sierra Madre: 1528

Silverton Quadrangle: 1059

Silverton area: 376,1694

Slick Rock district: 1491

Smizer Gulch Quadrangle: 678

Southern Ute Indian Reservation: 826

Spar City Quadrangle: 1561

Spring Hill Creek Quadrangle: 1269

Square S Ranch Quadrangle: 453, 693

St. Louis Peak Roadless Area: 524

Stuntz Reservoir Quadrangle: 718

Summitville district: 1564

Tanks Peak Quadrangle: 715

Telluride Quadrangle: 195, 380, 1060, 1061

Temple Canyon area: 797

Tenmile Range: 89

Tenmile district: 511

Tennessee Pass area: 1636

The Saddle Quadrangle: 875

Thirteenmile Creek Quadrangle: 1255

Thornburg oil and gas field: 464

Thornburgh Quadrangle: 1368, 1372

Tincup mining district: 637

Trail Mountain Quadrangle: 840

Uncompahgre mining district: 191, 1062

Upper Colorado River Basin: 582

Uravan Quadrangle: 276, 278

Ute Mountain Indian Reservation: 836

Ute Peak Quadrangle: 523

Vasquez Peak Wilderness Study Area: 524

Vernal $1^{\circ}$ by $2^{\circ}$ Quadrangle: 236, 237, 1430, 1431

Wagon Track Ridge Quadrangle: 894

Walsh Knolls Quadrangle: 252

Washboard Rock Quadrangle: 415

Weaver Ridge Quadrangle: 251

Westwater 4 SE Quadrangle: 504, 505

Westwater 4 SW Quadrangle: 504, 505

Westwater Quadrangle: 659 
Wetterhorn Peak Quadrangle: 1055

White River City Quadrangle: 1317

White Rock Quadrangle: 1319

Williams Fork Mountains area: 799

Williams Fork Roadless Area: 524

Willow Creek Butte Quadrangle: 704

Winter Flats Quadrangle: 887

Wolf Ridge Quadrangle: 452

Woody Creek Quadrangle: 576

Yankee Gulch Quadrangle: 457

Yellow Jacket Quadrangle: 669

Zenobia Peak Quadrangle: 713

Geomorphology: $1,10,26,34,40,44,45,46,98,129,130,142,197,231$, $236,293,301,310,335,357,359,389,395,410,510,574,589,594$, $599,634,653,658,724,725,749,759,774,775,779,784,794,820$, $847,853,880,881,896,897,898,899,901,948,966,980,992,1002$, $1011,1046,1088,1097,1098,1112,1117,1121,1155,1157,1195,1245$, $1279,1285,1286,1300,1323,1327,1380,1456,1471,1472,1515,1571$, $1625,1645,1657,1757,1785,1812,1819,1820,1821,1823,1836$

Geothermal resources: $64,65,66,105,217,235,284,289,320,515,528$, $552,598,984,1051,1292,1293,1294,1336,1377,1378,1728,1734$, $1840,1841,1842$

Gilman: $81,1048,1352,1524$

Gilman Sandstone: 621

Aquifer tests: 621

Dissolved solids: 621

Geologic sections: 621

Hydraulic conductivity: 621

Lithologic logs: 621

Storage coefficient or specific yield: 621

Transmissivity: 621

Water levels: 621

Water-quality analyses: 621

Glacial deposits: $179,791,1365,1366,1769$

Dissolved solids: 791,1769

Lithologic logs: 1769

Water levels: 791,1769

Water-quality analyses: 791,1769

Glaciology: $27,137,395,635,757,776,837,1381,1385,1401,1571$

Glen Canyon Group: $116,423,578,580,581,582,792,836,1032,1165,1581$

Aquifer tests: $836,1032,1581$

Dissolved solids: $116,582,792,836,1032,1582$

Geologic sections: 582, 1032

Hydraulic conductivity: 580, 581, 582, 792, 836, 1032

Lithologic logs: $792,836,1032$

Porosity: $580,581,792,1032$

Storage coefficient or specific yield: 582, 836, 1032

Transmissivity: $582,836,1032,1581$

Water levels: $580,792,836,1032,1581$

Water-quality analyses: $792,836,1032,1581$

Glenwood Canyon: $827,1188,1483,1689$

Glenwood Springs: $73,74,148,408,832,871,1076,1079,1659$

Gore Canyon: $56,759,1280$

Gore Creek Valley: 247 
Gore Range: 142, 614, 721, 1425, 1782, 1783

Gothic Formation: 68, 411, 628, 630, 1014, 1016, 1452

Dissolved solids: 630

Hydraulic conductivity: 630

Transmissivity: 630

Water levels: 630

Water-quality analyses: 630

Graben: 301,411

Granby: $531,697,1045,1442,1457$

Granby Anticline: 1045,1442

Grand County: 32, 56, 64, 83, 116, 120, 132, 133, 137, 185, 186, 282, 322, $324,325,328,351,369,483,505,518,523,524,528,531,553$, $580,581,582,614,618,619,620,621,622,632,643,644,655$, $659,670,671,674,697,732,742,743,767,771,786,824,837$, $838,839,840,841,842,843,845,846,851,895,984,1011,1018$, $1022,1026,1045,1080,1085,1086,1091,1092,1105,1110,1124$, $1161,1168,1174,1213,1214,1242,1246,1280,1285,1286,1291$, $1293,1312,1340,1343,1379,1381,1384,1433,1442,1493,1497$, $1535,1537,1556,1597,1598,1599,1603,1617,1622,1637,1642$, $1643,1653,1654,1699,1715,1731,1733,1736,1750,1751,1756$, $1769,1784,1802,1832$

Alluvium, undifferentiated: $621,632,742,743,824,1433,1699,1769$ Aquifer tests: 621

Belden Formation: 622

Browns Park Formation: 632

Cambrian System: 618, 619, 620, 1018, 1091, 1784

Carmel Formation: 580,581

Cedar Mountain Formation: 580, 581, 582

Cenozoic Erathem: 1340

Chaffee Formation: 621

Chinle Formation: $580,581,582$

Coalmont Formation: 1699

Cretaceous System: 580, 581, 582, 1091, 1379, 1731, 1756

Curtis Formation: 580

Cutler Formation: 622

Dakota Group: $116,580,581,582,1291,1756$

Devonian System: 618, 619,620,621, 1018, 1091, 1784

Dissolved solids: $64,116,282,582,621,632,742,743,1018,1340$, $1699,1731,1769$

Drill-stem tests: 1599

Dyer Dolomite Member of Chaffee Formation:

621

Eagle Valley Evaporite or Formation: 622

Elbert Formation: 622

Entrada Sandstone: $116,580,581,767$

Eocene Series: 632

Fort Union Formation: 632

Geologic sections: $582,618,621,742,743,824,1018,1291,1379$

Geophysical logs: $582,618,621,742,743,824,1018,1291,1379$

Gilman Sandstone: 621

Glacial deposits: 1769

Glen Canyon Group: 116, 580, 581, 582

Green River Formation: 116, 282, 742, 743, 824, 1379

Hermosa Formation: 622

Honaker Trail Formation: 622 
Ignacio Quartzite: 622

Iles Formation: 632

Jurassic System: $580,581,582,1091,1246,1379,1497,1731$

Kayenta Formation: 580

Lance Formation: 632

Laramie Formation: 369,771

Leadville Limestone: $116,621,622,742,743,824$

Lewis Shale: 632

Lithologic logs: 621, 1699, 1769

Lodore Formation: 622

Lower Cretaceous Series: 732

Madison Limestone: 621,622

Mancos Shale: $282,580,581,582,632$

Maroon Formation: 622

Mesaverde Group: 116, 282, 580, 581, 582, 632

Mesozoic Erathem: 580, 581, 582, 1340, 1597, 1599, 1750, 1751

Middle Jurassic Series: 1246

Middle Park Formation: 846

Minturn Formation: 622, 1617

Mississippian System: 618, 619,620,621, 1018, 1091, 1731, 1784

Moenkopi Formation: $580,581,582$

Molas Formation: 622

Morgan Formation: 622

Morrison Formation: $580,581,582$

Navajo Sandstone: 580

Ordovician System: 618,619,620, 1018, 1784

Ouray Limestone: 622

Paleozoic Erathem: 618, 619, 620, 622, 1018, 1340, 1379, 1597, 1599, 1784

Parachute Creek Member of Green River Formation: 1379

Paradox Member of Hermosa Formation: 622

Park City Formation: 622

Pennsylvanian System: 618, 619,620,622, 1018, 1091, 1379, 1731, 1784

Permian System: $618,619,620,622,1018,1091,1379,1497,1731,1784$

Pierre Shale: 843,1080

Pinkerton Trail Formation: 622

Precambrian Erathem: 1018, 1091, 1340, 1379, 1731, 1769

Quaternary System: 282, 1086, 1091, 1379, 1731

Rico Formation: 622

Robinson Limestone Member of Minturn Formation: 1617

San Rafael Group: 582

Sawatch Sandstone Formation: 622, 1784

Silurian System: 619, 1018

State Bridge Formation: 622

Summerville Formation: 580

Sundance Formation: 580

Tertiary System: 632, 838, 1091, 1213, 1379, 1597, 1599, 1731, 1769

Triassic System: $580,581,582,1091,1379,1497,1731$

Uinta Formation: $742,743,824,1379$

Uinta Mountain Group: 622

Valley-fill deposits: 116,632

Wasatch Formation: 632

Water levels: $580,621,632,1091,1124,1340,1433,1699,1751,1769$

Water-quality analyses: $64,282,528,621,632,742,743,1699,1731$, 1769 
Weber Sandstone: 622

Williams Fork Formation: 632

Wingate Sandstone: $116,580,767$

Grand Hogback: 15, 633, 1082, 1194, 1202, 1203, 1222, 1326, 1681, 1706, 1730

Grand Hogback coal field: 15

Grand Junction: $188,250,502,1031,1032,1174,1183,1222,1303,1341$, $1342,1455,1573,1788,1834$

Grand Mesa: $310,471,472,757,1381$

Grand Valley: 435, 602, 766, 785, 828, 945, 1174, 1238, 1713, 1789

Grassy Creek Anticline: 1028

Gray Head: 205

Grazing: 1069

Greasewood Gulch: 454

Green Lakes Valley: 1026

Green Mountain Reservoir: 1345

Green River: 52, 255, 945, 1021, 1022, 1125, 1609, 1630, 1673

Green River basin: 596, 999, 1000, 1001, 1017, 1667, 1715, 1731, 1828

Dissolved solids: 1731

Geohydrology: 1715

Geology: $596,999,1000,1017,1828$

Hydrology: 596,1715

Organics : 596

Stratigraphy: 1000

Water-quality analyses: 1731

Green River Formation: 5, 7, 31, 52, 116, 159, 211, 253, 255, 256, 257, 282, $301,302,307,308,342,352,392,398,403,428,430,460,466$, $470,550,645,683,689,742,743,779,780,781,782,792,824$, $886,900,944,957,964,1020,1021,1067,1106,1148,1195,1196$, $1197,1250,1321,1322,1323,1339,1379,1404,1405,1421,1422$, $1444,1495,1523,1525,1526,1533,1590,1628,1696,1700,1702$, $1742,1745,1748,1749,1765,1771,1846$

Aquifer tests: $307,352,392,1766$

Dissolved solids: 5, 7, 116, 159, 211, 282, 307, 308, 343, 352, 392, $550,742,743,780,781,782,790,945,1020,1021,1339,1444$, $1700,1702,1745,1749,1771$

Drill-stem tests: $780,1700,1702,1771$

Geologic sections: $7,159,211,307,308,398,403,742,743,780,781$, $782,824,1339,1379,1404,1405,1590,1702,1742,1745,1749$

Geophysical logs: $307,398,780,1745,1771$

Hydraulic conductivity: 792, 1106,1148

Lithologic logs: 7, 308, 352, 398, 780, 792, 1339

Porosity: $781,782,792,1148$

Storage coefficient or specific yield: $782,1106,1148,1590,1745,1771$

Transmissivity: $7,352,550,780,1106,1765,1771$

Water levels: $5,7,159,342,352,403,550,781,782,792,1339,1702$, 1745,1771

Water-quality analyses: $5,7,159,211,282,307,308,342,352,392$, $550,742,743,780,781,782,792,944,1020,1021,1339,1444$, $1700,1702,1745,1749,1771$

Greenhorn Limestone: 538

Grizzly Peak: 385

Ground-water dating: 944

Groundhog Mine: 696

Gunnison: $28,503,630,707,749,1153,1224,1241,1361,1386,1774$ 
Gunnison County: $5,10,11,27,28,47,64,70,104,115,116,146,148,160$, $174,175,182,235,282,325,329,382,397,414,415,416,420$, $446,462,473,500,501,503,508,528,530,552,573,580,581$, $582,605,608,609,610,611,612,613,618,619,620,621,622$, $628,630,637,638,641,703,705,707,742,743,745,746,747$, $748,749,768,770,783,798,821,822,824,890,893,913,919$, $920,958,977,988,989,990,991,992,1014,1016,1018,1053$, $1087,1091,1093,1124,1129,1150,1153,1199,1203,1206,1207$, $1224,1240,1241,1259,1260,1261,1262,1264,1265,1266,1291$, $1312,1325,1331,1332,1340,1351,1353,1360,1361,1379,1380$, $1401,1424,1435,1452,1479,1521,1540,1560,1597,1599,1613$, $1614,1620,1623,1653,1654,1655,1684,1686,1687,1691,1701$, $1731,1750,1751,1774,1784,1786,1792,1811,1822,1830,1837$, $1840,1841,1845$

Alluvium, terrace: 115

Alluvium, undifferentiated: $5,148,621,630,742,743,824$

Aquifer tests: 621

Belden Formation: $622,630,992$

Burro Canyon Formation: 5, 148, 630, 1613

Cambrian System: $618,619,620,1018,1091,1784$

Carmel Formation: 580,581

Cedar Mountain Formation: $580,581,582$

Cenozoic Erathem: 609, 610, 1340

Chaffee Formation: 621,1380

Chinle Formation: $148,446,580,581,582$

Coffman Formation: 573

Cretaceous System: 580, 581, 582, 610, 893, 1091, 1379, 1731

Curtis Formation: 580

Cutler Formation: 622

Dakota Group: 5, 116, 148, 580, 581, 582, 630,1291, 1452, 1613

Devonian System: $618,619,620,621,1018,1091,1614,1784$

Dissolved solids: $5,64,115,116,148,282,582,621,630,742,743$, $1018,1340,1731$

Dockum Group: 446

Drill-stem tests: 1599

Dyer Dolomite Member of Chaffee Formation: 621

Eagle Valley Evaporite or Formation: 148, 622, 1016

Elbert Formation: 622

Entrada Sandstone: $116,148,580,581,630,1452$

Eocene Series: 27, 28, 893

Geologic sections: $582,618,621,742,743,824,1018,1291,1379$

Geophysical logs: $582,618,621,742,743,824,1018,1291,1379$

Gilman Sandstone: 621

Glen Canyon Group: $116,580,581,582$

Gothic Formation: 628, 630, 1014, 1016, 1452

Green River Formation: 5, 116, 282, 742, 743, 824, 1379

Hermos a Formation: 622, 1684

Holocene Series: 1087

Honaker Trail Formation: 622

Ignacio Quartzite: 622

Intrusive rocks: 5

Junction Creek Sandstone: 630

Jurassic System: 580, 581, 582, 991, 1091, 1379, 1731, 1822

Kayenta Formation: 580 
Leadville Limestone: $116,621,622,630,742,743,824,1691,1811$

Lithologic logs: 115,621

Lodore Formation: 622

Madison Limestone: 621,622

Mancos Shale: 5, 115, 148, 282, 580, 581, 582, 630, 1241, 1452

Maroon Formation: $148,622,628,630,990,1016,1199,1452$

Mesaverde Group: $5,116,148,282,501,580,581,582,610,630,893$, $1241,1774,1837$

Mesozoic Erathem: 580, 581, 582, 1340, 1452, 1597, 1599, 1750, 1751

Middle Pennsylvanian Series: 1014, 1016

Minturn Formation: 622, 1016

Miocene Series: 630

Mississippian System: 618,619,620,621, 1018, 1091, 1731, 1784, 1811

Moenkopi Formation: $580,581,582$

Molas Formation: 622

Morgan Formation: 622

Morrison Formation: 5, 115, 148, 580, 581, 582, 630, 1452

Navajo Sandstone: 580

Ohio Creek Formation: 608, 630

Oligocene Series: 630

Ordovician System: $618,619,620,1018,1784$

Ouray Limestone: 622

Paleozoic Erathem: 609, 618, 619,620, 622, 1018, 1340, 1379, 1452, $1597,1599,1784$

Parachute Creek Member of Green River Formation: 5, 1379

Paradox Member of Hermosa Formation: 622, 1016

Park City Formation: 622

Peerless Formation: 630

Pennsylvanian System: .70, 618, 619,620,622, 628, 988, 989, 1014, $1016,1018,1091,1379,1684,1731,1784$

Permian System: $70,618,619,620,622,628,988,989,1018,1091,1379$, 1731,1784

Pinkerton Trail Formation: 622

Precambrian Crystalline rocks: 115

Precambrian Erathem: 10, 11, 609, 630, 749, 822, 1018, 1091, 1340, 1379, 1731

Quaternary System: 282, 1087, 1091, 1379, 1401, 1731

Rico Formation: 622

Robinson Limestone Member of Minturn Formation: 1016

San Rafael Group: 582, 1822

Sawatch Sandstone Formation: 622, 630, 1784

Silurian System: 619,1018

State Bridge Formation: 148, 622

Summerville Formation: 580

Sundance Formation: 580

Tertiary System: $115,893,1091,1266,1379,1597,1599,1731$

Triassic System: 446, 580, 581, 582, 1091, 1379, 1731

Uinta Formation: $5,742,743,824,1379$

Uinta Mountain Group: 622

Upper Cretaceous Series: 501, 610, 770, 890, 893

Upper Devonian Series: 1380

Upper Triassic Series: 446

Valley-fill deposits: 115, 116

Wanakah Formation: 115 
Wasatch Formation: 5, 148, 610, 630

Water levels: $5,115,580,621,630,1091,1124,1340,1751$

Water-quality analyses: $5,64,115,151,282,528,551,621,630,742$, $743,1053,1701,1731$

Weber Sandstone: 148,622

Wingate Sandstone: 116,580

Gunnison River: 5, 397, 705, 710, 714, 822, 919, 920, 1789

Gunnison River basin: 159

Gypsum: 260, 1098, 1397, 1575, 1807

Gypsum Gap: 260

Gypsum Valley: 1575, 1807

Hahns Peak: 62, 623, 823, 1472

Hamilton: 1163,1164

Hamm Canyon: 269, 270

Hams Fork: 596

Handie's Peak: 1057

Harding Sandstone: 1425

Harley Dome: 504, 505

Hawxhurst Creek: 437

Hayden: 175, 285, 507, 1349

Hayden Peak: 175

Haystack Rock: 716

Hells Canyon: 719

Henders on Ridge: 1416

Hermosa Formation: $91,145,147,157,622,722,775,815,853,934,1684$, 1766,1815

Dissolved solids: $147,157,722,1766$

Drill-stem tests: 1766

Geologic sections: $157,722,775$

Geophysical logs: 775

Hydraulic conductivity: 622

Porosity: 622

Water levels: 157,1766

Water-quality analyses: 147, 157, 722, 1766

Hermosa Peak: 1334

Highland Peak: 177

Hinsdale County: $36,38,39,64,116,189,196,197,258,296,323,329,336$, $362,372,373,416,528,580,581,582,619,620,622,635,636$, $640,641,722,742,743,824,833,926,927,969,993,994,1018$, $1024,1055,1057,1058,1063,1091,1124,1185,1259,1291,1312$, $1340,1377,1379,1432,1479,1558,1560,1597,1599,1655,1726$, $1731,1750,1751,1784$

Alluvium, undifferentiated: $742,743,824$

Belden Formation: 622

Cambrian System: $619,620,722,1018,1091,1784$

Carmel Formation: 580, 581

Cedar Mountain Formation: $580,581,582$

Cenozoic Erathem: 1340

Chinle Formation: $580,581,582$

Cretaceous System: 580, 581, 582, 1091, 1379, 1731

Curtis Formation: 580

Cutler Formation: 622

Dakota Group: $116,362,580,581,582,1291,1432$

Devonian System: $619,620,1018,1091,1784$ 
Dissolved solids: $64,116,582,722,742,743,1018,1340,1731$

Drill-stem tests: 1599

Eagle Valley Evaporite or Formation: 622

Elbert Formation: 622

Entrada Sandstone: $116,580,581$

Fruitland Formation: 1432

Geologic sections: $582,722,742,743,824,1018,1291,1379$

Geophysical logs: $582,722,742,743,824,1018,1291,1379$

Glen Canyon Group: 116, 580, 581, 582

Green River Formation: 116, 742, 743, 824, 1379

Hermosa Formation: 622, 722

Honaker Trail Formation: 622, 722

Ignacio Quartzite: 622

Irving Formation: 640

Jurassic System: $580,581,582,1091,1379,1731$

Kayenta Formation: 580

Leadville Limestone: $116,622,742,743,824$

Lodore Formation: 622

Madison Limestone: 622

Mancos Shale: 580, 581, 582

Maroon Formation: 622

Mesaverde Group: 116, 580, 581, 582, 1432

Mesozoic Erathem: $580,581,582,1340,1597,1599,1750,1751$

Minturn Formation: 622

Mississippian System: 619, 620, 722, 1018, 1091, 1731, 1784

Moenkopi Formation: $580,581,582$

Molas Formation: 622

Morgan Formation: 622

Morrison Formation: $580,581,582$

Navajo Sandstone: 580

Ordovician System: $619,620,1018,1784$

Ouray Limestone: 622

Paleozoic Erathem: 619,620,622, 1018, 1340, 1379, 1597, 1599, 1784

Parachute Creek Member of Green River Formation: 1379

Paradox Member of Hermosa Formation: 622, 722

Park City Formation: 622

Pennsylvanian System: 38, 39, 619, 620,622, 636, 722, 1018, 1091, 1379, $1726,1731,1784$

Permian System: 619, 620, 622, 722, 1018, 1091, 1379, 1731, 1784

Pinkerton Trail Formation: 622, 722

Precambrian Erathem: 197, 1018, 1091, 1340, 1379, 1731

Quaternary System: 635, 1091, 1379, 1731

Rico Formation: 622

San Rafael Group: 582

Sawatch Sandstone Formation: 622, 1784

Silurian System: 619,1018

State Bridge Formation: 622

Summerville Formation: 580

Sundance Formation: 580

Tertiary System: 1091, 1379, 1597, 1599, 1731

Triassic System: 580, 581, 582, 1091, 1379, 1731

Uinta Formation: $742,743,824,1379$

Uinta Mountain Group: 622

Valley-fill deposits: 116 
Water levels: $362,580,1091,1124,1340,1751$

Water-quality analyses: $64,528,722,742,743,1731$

Weber Sandstone: 622

Wingate Sandstone: 116,580

Holocene Series: 1087, 1499

Holy Cross: 1639

Homestake shear zone: 1524

Honaker Trail Formation: 37, 622, 722, 775, 1169, 1815

Dissolved solids: 722

Geologic sections: 722,775

Geophysical logs: 775

Hydraulic conductivity: 622

Porosity: 622

Water-quality analyses: 722

Horse Draw: 161,1364

Horse Gulch: 1163

Horse Mountain: 246

Horse Range Mesa: 271

Horsefly Peak: 691

Hot Sulphur Springs: 120, 839, 841, 845, 1293, 1493

Hotchkiss : 676

Housetop Mountain: 436

Houston Gulch: 1261

Howa rdsville: 1058

Huerfano Formation: 536

Hunter Canyon: 1222

Hunter-Fryingpan Wilderness Area: 1052

Hydraulic conductivity: $50,581,585,586,618,1341,1599,1696,1750,1827$

Hydrocarbons: $8,917,1291,1390$

Hydrochemistry: $296,526,528,552,742,743,782,922,1013,1022,1053$,

$1132,1312,1618,1715$

Hydrodynamics : $48,49,52,722,922$

Ignacio: 59

Ignacio Quartzite: 147,622

Dissolved solids: 147

Hydraulic conductivity: 622

Porosity: 622

Water-quality analyses: 147

Iles Dome: 961

Iles Formation: 149, 402, 405, 545, 632, 1043, 1044, 1081, 1082, 1083, 1371, $1372,1446,1506,1507,1572$

Aquifer tests: 1572

Dissolved solids: $149,632,1572$

Geologic sections: 1572

Hydraulic conductivity: 632, 1572

Storage coefficient or specific yield: 1572

Transmissivity: 1572

Water levels: 632,1446

Water-quality analyses: 149, 632, 1572

Iles Mountain: 996

Illinois River: 1105,1161

Independence Pass: 1692

Indian Creek: 1360

Indian Valley: 1318 
Indian Water Canyon: 1428

Injection wells: 775,1812

Intrusive rocks: 5, 157

Dissolved solids: 5,157

Geologic sections: 157

Water levels: 5,157

Water-quality analyses: 5,157

Iris: $10,11,747,1142,1260$

Iron: $104,158,194,237,258,282,323,324,325,326,328,329,351,402$, $410,499,536,546,572,653,920,950,951,1013,1016,1061,1067$, $1276,1301,1343,1344,1345,1380,1402,1456,1516,1535,1552,1573$, $1579,1580,1592,1593,1627,1660,1698,1737,1748,1826,1827$

Iron oxides: 1580

Ironton: 194

Irrigation: $304,497,602$

Irving Formation: 640

Isotope: $104,393,404,440,564,944,1829$

Italian Mountain: 382,1331

Jefferson: 58,765

Jessup Gulch: 455

Jim Canyon: 658

Joe Davis Hill: 272, 273

Juanita Arch: 1500, 1501

Junction Creek Sandstone: 630, 836, 1605

Aquifer tests: 836

Dissolved solids: 630,836

Geologic sections: 1605

Hydraulic conductivity: 630,836

Lithologic logs: 836

Storage coefficient or specific yield: 836

Transmissivity: 630,836

Water levels: 630,836

Water-quality analyses: 630,836

Juniper Mountain: 2, 3, 303, 1677

Jurassic System: 6, 95, 135, 136, 423, 547, 580, 581, 582, 585, 598, 617, $653,785,795,955,991,1089,1091,1165,1166,1245,1246,1249$, $1252,1301,1302,1304,1305,1379,1386,1496,1497,1549,1632$, $1657,1731,1741,1766,1818,1819,1820,1821,1822,1823$

Aquifer tests: 598

Dissolved solids: $582,598,617,1731,1766$

Drill-stem tests: 1766

Geologic sections: 582, 585, 598, 617, 1379, 1741

Geophysical logs: 598

Hydraulic conductivity: $580,581,582,617$

Lithologic logs: 598, 617, 1741

Porosity: 580,581

Storage coefficient or specific yield: 582,598

Transmissivity: 582,598

Water levels: $580,598,617,1091,1766$

Water-quality analyses: 598, 617, 1731, 1766

Karst: $408,410,1111,1112$

Kayenta Formation: 159, 580, 1032, 1165, 1605

Aquifer tests: 1032

Dissolved solids: 159,1032 
Geologic sections: 159, 1032, 1605

Hydraulic conductivity: 580, 1032

Lithologic logs: 1032

Porosity: 580, 1032

Storage coefficient or specific yield: 1032

Transmissivity: 1032

Water levels: $159,580,1032$

Water-quality analyses: 159, 1032

Kerber Creek: 143

King Mountain: 1481

Kinney Rim: 1419

Kirtland Shale: 147, 150, 151, 157, 212, 533, 537, 826, 836, 1176

Aquifer tests: 836

Dissolved solids: $147,157,212,826,836$

Geologic sections: 157

Hydraulic conductivity: 836

Lithologic logs: $150,151,836$

Storage coefficient or specific yield: 836

Transmissivity: 836

Water levels: $157,826,836$

Kline: 1463

Water-quality analyses: $147,157,212,826,836$

Klondike Ridge: 1703

Kremmling: $56,842,843,1384,1790$

Kremmling Sandstone Member of Pierre Shale: 1790

La Plata: $384,475,477,478,539,672,979,982,1219,1333,1350,1582$, 1621,1766

La Plata County: 25, 26, 29, 37, 57, 59, 60, 64, 107, 147, 150, 151, 157, $197,212,321,323,337,362,375,384,393,474,475,477,478$, $528,529,532,537,539,583,584,585,635,640,672,722,733$, $734,742,743,775,778,824,826,836,922,940,979,1003,1071$, $1072,1077,1091,1100,1102,1103,1124,1127,1159,1176,1182$, $1185,1186,1219,1284,1291,1312,1334,1340,1350,1378,1379$, $1432,1441,1454,1463,1478,1504,1508,1529,1539,1562,1582$, $1604,1621,1724,1736,1795,1800,1802,1827,1843$

Alluvium, flood plain: 151,826

Alluvium, terrace: 147,826

Alluvium, undifferentiated: $147,150,157,742,743,824,826,836$ Animas Formation: $147,150,151,157,212,826$

Aquifer tests: 836

Bluff Sandstone: 585

Brushy Basin Shale Member of Morrison Formation: 29

Burro Canyon Formation: 29, 147, 150, 151, 836

Cambrian System: 722, 1091

Cenozoic Erathem: 337, 1340

Cliff House Sandstone: 147, 150, 151, 157, 212, 532, 585, 826, 836

Cretaceous System: $537,539,585,1091,1100,1182,1284,1379,1508$

Cutler Formation: $37,147,157,775$

Dakota Group: 29, 147, 150, 151, 157, 212, 362, 393, 585, 836, 1291, 1432

Devonian System: 1091

Dissolved solids: $64,147,157,212,722,742,743,826,836,922,1340$ Dolores Formation: 107, 147, 157

Drill-stem tests: 922 
Elbert Formation: 147

Entrada Sandstone: $147,585,836,1071$

Fruitland Formation: $147,150,151,157,212,537,539,826,836,922$, $1100,1176,1432$

Geologic sections: $157,393,585,722,742,743,775,824,922,1071$, 1291,1379

Geophysical logs: 157, 393, 585, 722, 742, 743, 775, 824, 922, 1071, 1291,1379

Glen Canyon Group: 836

Green River Formation: 742, 743, 824, 1379

Hermosa Formation: 147, 157, 722, 775

Honaker Trail Formation: 37, 722, 775

Ignacio Quartzite: 147

Intrusive rocks: 157

Irving Formation: 640

Junction Creek Sandstone: 836

Jurassic System: 585, 1091, 1379

Kirtland Shale: $147,150,151,157,212,537,826,836,1176$

Leadville Limestone: $25,26,37,147,742,743,824$

Lewis Shale: $147,150,151,157,212,537,539,826,836,1100,1176$, 1441

Lithologic logs: $150,151,836$

Mancos Shale: 29, 147, 150, 151, 157, 212, 585, 826, 836, 1176

McDermott Member of Animas Formation: 836

Menefee Formation: $147,150,151,157,212,585,826,836,1176,1284$

Mesaverde Group: $147,150,157,212,585,778,826,836,1071,1432$

Mesozoic Erathem: $337,1077,1340$

Mississippian System: 25, 722, 1091

Molas Formation: $37,147,157,775,1159$

Morrison Formation: $29,147,150,151,157,212,393,585,836,1071$

Navajo Sandstone: 836

Niobrara Formation: 1176

Paleocene Series: 537,1508

Paleozoic Erathem: 37, 1340, 1379

Parachute Creek Member of Green River Formation: 1379

Paradox Member of Hermosa Formation: 722, 775

Pennsylvanian System: 722, 1091, 1127, 1379, 1539

Permian System: 722, 1091, 1379

Pictured Cliffs Sandstone: $147,150,151,157,532,537,539,826,836$, $1100,1176,1441$

Pinkerton Trail Formation: $37,722,775$

Pleistocene Series: 672

Point Lookout Sandstone: 147, 150, 151, 157, 212, 585, 836, 1176

Precambrian Erathem: 37, 57, 197, 1091, 1340, 1379

Quaternary System: 635, 1091, 1379

Rico Formation: 147,157

San Jose Formation: $150,151,157,212,826$

San Rafael Group: 836

Summerville Formation: 585, 836

Terrace deposits: $150,151,157$

Tertiary System: 1071, 1077, 1091, 1379, 1508

Todilto Formation: 585

Triassic System: 1091, 1379

Uinta Formation: $742,743,824,1379$ 
Upper Cretaceous Series: 537, 1100, 1176, 1182, 1284, 1441, 1508 Upper Jurassic Series: 29

Valley-fill deposits: 826,1071

Wanakah Formation: 150,151

Water levels: $157,362,826,836,1091,1124,1340$

Water-quality analyses: $64,147,157,212,393,528,722,742,743,826$, 836,922

La Sa1: $239,241,242,244,1183$

La Sal Mountains: 1766

Lake Albion: 1026

Lake City Caldera: 1024

Lake Haiyaha: 1232

Lake Husted: 1232

Lake Mountain: 173

Lance Formation: 149, 354, 632, 787, 834, 1000

Dissolved solids: $149,354,632$

Hydraulic conductivity: 632

Water levels: 354,632

Water-quality analyses: 149, 354, 632

Land management: 1068

Land use: $218,572,1343,1515,1592,1627$

Landsat: $301,587,750,1156$

Laney Member of Green River Formation: 964

Laramie Formation: 369,771

Lay: $92,93,94,106,168,169,172,220,526,1532,1787$

Lead: 282,1232

Leadville Limestone: $6,25,26,37,80,81,116,147,340,408,410,621$, $622,630,699,742,743,769,800,824,871,1208,1439,1524,1691$, 1766,1811

Aquifer tests: 621

Dissolved solids: $116,147,621,630,699,742,743,1766$

Drill-stem tests: 1766

Geologic sections: $621,742,743,824$

Hydraulic conductivity: $621,622,630$

Lithologic logs: 621

Porosity: 622

Storage coefficient or specific yield: 621

Transmissivity: 621,630

Water levels: $621,630,1766$

Water-quality analyses: $147,621,630,699,742,743,1766$

Legislation: 921,1123

Lenado: 830

Lewis Shale: $147,149,150,151,157,212,354,537,539,632,826,834,836$, $1100,1101,1176,1441,1572,1718$

Aquifer tests: 836,1572

Dissolved solids: $149,150,157,212,354,632,826,836,1572$

Geologic sections: 157,1572

Hydraulic conductivity: $632,836,1572$

Lithologic logs: $150,151,836$

Storage coefficient or specific yield: 836, 1572

Transmissivity: 836,1572

Water levels: $157,354,632,826,836$

Water-quality analyses: $147,149,157,212,354,632,826,836,1572$ 
Lime Creek: 1538

Lineaments : 588

Lisbon Valley: 1758, 1759, 1760, 1763

Little Cone: 208, 209

Lodore Formation: $622,763,1425,1581$

Aquifer tests: 1581

Dissolved solids: 1581

Hydraulic conductivity: 622

Porosity: 622

Transmissivity: 1581

Water levels: 1581

Water-quality analyses: 1581

Log Hill Mesa: 682

Lone Mountain: 1135

Long Point: 874

Loveland Pass: 523

Lower Cretaceous Series: 357, 496, 547, 724, 725, 732, 1805

Lower Devonian Series: 547

Lower Mississippian Series: 24, 410

Lower Permian Series: 230, 1172

Lower Triassic Series: 547, 1117

Madison Limestone: 621, 622, 792

Aquifer tests: 621

Dissolved solids: 621,792

Geologic sections: 621

Hydraulic conductivity: 621, 622, 792

Lithologic logs: 621, 792

Porosity: 622, 792

Storage coefficient or specific yield: 621

Transmissivity: 621

Water levels: 621,792

Water-quality analyses: 621, 792

Mancos Shale: 5, 8, 29, 115, 129, 130, 135, 136, 147, 148, 149, 150, 151, $157,159,212,282,354,412,469,506,526,580,581,582,585$, $598,630,632,633,634,792,826,836,932,948,949,982,1032$, $1042,1043,1088,1147,1176,1184,1220,1241,1452,1480,1481$, $1532,1536,1581,1605,1730,1741,1790,1835$

Aquifer tests: $598,836,1032,1581$

Dissolved solids: $5,115,147,148,149,157,159,212,282,354,582$, $598,630,632,792,826,836,1032,1147,1581$

Geologic sections: 157, 159, 582, 585, 598, 1032, 1147, 1605, 1741

Geophysical logs: 598

Hydraulic conductivity: $580,581,582,630,632,791,836,1032$

Lithologic logs: 115, 150, 151, 598, 792, 836, 1032, 1147, 1741

Porosity: $580,581,792,1032$

Storage coefficient or specific yield: $582,598,836,1032$

Transmissivity: $582,598,630,836,1032,1581$

Water levels: $5,115,157,159,354,580,598,630,632,792,826,836$, $1032,1147,1581$

Water-quality analyses: $5,115,147,148,149,157,159,212,282,354$, $598,630,632,792,826,836,1032,1581$

Manganese: 282,1516 
Manitou Formation: 699, 831, 1425

Dissolved solids: 699

Water-quality analyses: 699

Maps, by geohydrologic unit and theme:

Alluvium, undifferentiated:

Constituent concentration: $781,1021,1341,1745$

Potentiometric surface: 307, 621, 625, 1433, 1682, 1766

Structure: 625,1682

Thickness: 625,1682

Burro Canyon Formation:

Potentiometric surface: 1605

Cambrian System:

Lithology-thickness: 618

Potentiometric surface: 6

Thickness: 618

Carmel Formation:

Potentiometric surface: 1605

Structure: 1605

Cedar Mountain Formation:

Potentiometric surface: 582

Thickness: 582

Chaffee Formation:

Hydraulic conductivity: 621

Lithology-thickness: 621

Potentiometric surface: 621

Thickness: 621

Transmissivity: 621

Chinle Formation:

Potentiometric surface: 582

Thickness: 582

Cretaceous System:

Potentiometric surface: 1766

Dakota Group:

Constituent concentration: 362

Potentiometric surface: 362, 582, 598, 1605

Structure: 362,1605

Thickness: 582,1291

Devonian System:

Constituent concentration: 1018

Hydraulic conductivity: 621

Lithology-thickness: 619,621

Porosity: 619

Potentiometric surface: $618,619,621,1018$

Structure: 1018

Thickness: $618,619,621,1018$

Transmissivity: $618,619,621$

Douglas Creek Member of Green River Formation:

Constituent concentration: 781, 782, 1020, 1021

Potentiometric surface: 781,782

Transmissivity: 781,782

Duchesne River Formation:

Potentiometric surface: 791 
Dyer Dolomite Member of Chaffee Formation:

Hydraulic conductivity: 621

Lithology-thickness: 621

Potentiometric surface: 621

Thickness: 621

Transmissivity: 621

Elbert Formation:

Potentiometric surface: 6, 1766

Entrada Sandstone:

Potentiometric surface: 585, 1605

Structure: 1032,1605

Transmissivity: 585

Fruitland Formation:

Potentiometric surface: 922

Gilman Sandstone:

Hydraulic conductivity: 621

Lithology-thickness: 621

Potentiometric surface: 621

Thickness: 621

Transmissivity: 621

Glacial deposits:

Potentiometric surface: 792

Glen Canyon Group:

Potentiometric surface: 582

Structure: 582

Thickness: 582

Green River Formation:

Constituent concentration: $781,782,1020,1021,1379,1404,1405$, 1444,1745

Hydraulic conductivity: $781,782,1404,1405$

Potentiometric surface: $307,403,550,781,782,944,1404,1405$, $1444,1745,1749,1771$

Storage coefficient or specific yield: 781,782

Structure: $307,1404,1405,1745$

Thickness: $307,1404,1405$

Transmissivity: $781,782,1745$

Hermosa Formation:

Lithology-thickness: 1766

Structure: 775

Honaker Trail Formation:

Potentiometric surface: 722

Junction Creek Sandstone:

Potentiometric surface: 1605

Jurassic System:

Constituent concentration: 580

Potentiometric surface: 1766

Kayenta Formation:

Potentiometric surface: 1605

Structure: 1605

Leadville Limestone:

Hydraulic conductivity: 621

Lithology-thickness: 621

Potentiometric surface: 6, 621, 1766

Thickness: 621

Transmissivity: 621 
Madison Limestone:

Hydraulic conductivity: 621

Lithology-thickness: 621

Potentiometric surface: 621

Thickness: 621

Transmissivity: 621

Mancos Shale:

Potentiometric surface: 582,598

Thickness: 582

Mesaverde Group:

Constituent concentration: 582, 1071

Potentiometric surface: 582

Thickness: 158, 582

Transmissivity: 1071

Mesozoic Erathem:

Potentiometric surface: 582

Structure: 582

Thickness: 582

Mississippian System:

Constituent concentration: 1018

Hydraulic conductivity: 621

Lithology-thickness: $618,619,621$

Porosity: 619

Potentiometric surface: $618,619,621,722,1018$

Structure: 1018

Thickness: $618,619,621,1018$

Transmissivity: $618,619,621$

Moenkopi Formation:

Potentiometric surface: 582

Thickness: 582

Morrison Formation:

Constituent concentration: 582,1071

Potentiometric surface: 393, 582, 585, 1605

Thickness: 582

Transmissivity: 585,1071

Navajo Sandstone:

Potentiometric surface: 1605

Structure: 1605

Ordovician System:

Thickness: 618

Ouray Limestone:

Potentiometric surface: 6, 1766

Paleozoic Erathem:

Thickness: 619

Parachute Creek Member of Green River Formation:

Constituent concentration: $781,1020,1021,1379,1404,1405,1444$, 1745

Hydraulic conductivity: 781, 782, 1404, 1405

Potentiometric surface: 403, 781, 782, 1404, 1405, 1444, 1745, 1749,1771

Storage coefficient or specific yield: 781,782

Structure: $307,1404,1405,1745$

Thickness: $307,1404,1405$

Transmissivity: 1745 
Paradox Member of Hermosa Formation:

Lithology-thickness: 1766

Potentiometric surface: 722

Structure: 775

Pennsylvanian System:

Constituent concentration: 1018

Hydraulic conductivity: 620

Lithology-thickness: 618,619

Porosity: 619, 1784

Potentiometric surface: $618,619,1018,1766$

Structure: 1018

Thickness: $618,619,1018$

Transmissivity: 618,619

Permian System:

Constituent concentration: 1018

Hydraulic conductivity: 620

Lithology-thickness: 618,619

Porosity: 619, 1784

Potentiometric surface: 618,619, 722, 1018, 1766

Structure: 1018

Thickness: $618,619,1018$

Transmissivity: 618,619

Pinkerton Trail Formation:

Potentiometric surface: 722

San Rafael Group:

Constituent concentration: 582

Potentiometric surface: 582

Thickness: 582

Tertiary System:

Constituent concentration: 1071

Potentiometric surface: 1766

Triassic System:

Constituent concentration: 580

Potentiometric surface: 1766

Uinta Formation:

Constituent concentration: 1379, 1404, 1405, 1444, 1745

Hydraulic conductivity: 1404, 1405

Potentiometric surface: 791, 944, 1404, 1405, 1444, 1745, 1771

Structure: 1404,1405

Thickness: 1404, 1405

Transmissivity: 1745

Valley-fill deposits:

Constituent concentration: 1071

Weber Sandstone:

Constituent concentration: 791

Structure: 791

Williams Fork Formation:

Potentiometric surface: 1446

Wingate Sandstone:

Potentiometric surface: 1605

Structure: 1605

Marble: 611,1424

Marcellina Mountain: 612

Maroon Bells: 174 
Maroon Formation: $73,148,411,424,622,628,630,631,699,907,909,910$, $911,912,990,1016,1049,1099,1172,1173,1199,1450,1452,1706$, 1707

Dissolved solids: $148,630,631,699$

Hydraulic conductivity: 622, 630

Porosity: 622

Transmissivity: 630

Water levels: 630

Water-quality analyses: $148,630,631,699$

Marshall Creek: 527

Marshall Pass mining district: 1263

Maudlin Gulch: 797

Maybe11: $92,93,94,788,1136$

Mayflower Gulch: 1355

McCarthy Gulch: 1256

McCoy: 290, 291, 439, 699, 803, 1449, 1496, 1497, 1567, 1711

McDermott Member of Animas Formation: 336, 836

Aquifer tests: 836

Dissolved solids: 836

Hydraulic conductivity: 836

Lithologic logs: 836

Storage coefficient or specific yield: 836

Transmissivity: 836

Water levels: 836

Water-quality analyses: 836

McElmo Dome: 1839

Meadow Mountain: 318

Meadow Ranch landslide: 1536

Meeker: $170,541,702,1220$

Mellen Hill: 387

Menefee Formation: 147, 150, 151, 157, 212, 288, 585, 826, 836, 1176, 1284 Aquifer tests: 836

Dissolved solids: $147,157,212,826,836$

Geologic sections: 157,585

Hydraulic conductivity: 836

Lithologic logs: 150, 151, 836

Storage coefficient or specific yield: 836

Transmissivity: 836

Water levels: $157,826,836$

Water-quality analyses: $147,157,212,826,836$

Mercury: 1516

Mesa County: $4,6,7,64,85,116,158,159,211,226,230,248,250,261$, $262,264,265,275,282,307,308,325,327,401,427,432,433$, $434,436,437,446,471,483,500,501,502,504,505,528,559$, $570,580,581,582,588,618,619,620,621,622,649,658,659$, $668,670,671,722,728,742,743,758,767,775,785,818,824$, $849,850,861,886,887,890,894,895,896,897,898,899,900$, $960,970,998,1018,1030,1031,1032,1034,1042,1073,1091,1124$, $1234,1238,1245,1246,1254,1274,1291,1299,1303,1310,1311$, $1312,1340,1341,1379,1455,1461,1462,1500,1501,1505,1547$, $1576,1590,1592,1597,1599,1653,1654,1701,1702,1706,1707$, $1709,1712,1731,1741,1746,1750,1751,1766,1770,1780,1781$, $1784,1788,1802,1816,1823,1833,1834,1835,1837$ 
Alluvium, undifferentiated: $7,159,307,308,621,742,743,824,1032$, $1341,1766,1770$

Anvil Points Member of Green River Formation: 7, 211

Aquifer tests: $308,621,1032$

Belden Formation: 622,1707

Burro Canyon Formation: 159, 1032

Cambrian System: 6, 618,619,620, 722, 1018, 1091, 1766, 1784

Carmel Formation: 580,581

Cedar Mountain Formation: 580, 581, 582

Cenozoic Erathem: 1340

Chaffee Formation: 621

Chinle Formation: 159, 446, 580, 581, 582, 1032

Cozzette Member of Price River Formation: 502

Cretaceous System: 6,559,570,580,581, 582, 899, 1091, 1379, 1731, $1741,1766,1834$

Curtis Formation: 580

Cutler Formation: $622,775,1073,1505,1780,1781$

Dakota Group: $116,159,504,580,581,582,1032,1042,1291,1741$

Devonian System: $6,618,619,620,621,1018,1091,1766,1784$

Dissolved solids: $4,7,64,116,159,211,282,307,308,582,621,722$, $742,743,960,1018,1032,1311,1340,1702,1731,1746,1766$

Dockum Group: 446

Douglas Creek Member of Green River Formation: 7, 211, 886

Drill-stem tests: $1599,1702,1766$

Dyer Dolomite Member of Chaffee Formation: 621

Eagle Valley Evaporite or Formation: 622, 1707

Elbert Formation: 6, 622, 1766

Entrada Sandstone: 116, 159, 580, 581, 767, 1032, 1254

Eocene Series: 886

Garden Gulch Member of Green River Formation: 7, 211, 886, 1590

Geologic sections: 7, 158, 159, 211, 307, 308, 582, 618, 621, 722, 742, $743,775,824,960,1018,1032,1291,1379,1590,1592,1702,1741$, 1770

Geophysical logs: 7, 158, 159, 211, 307, 308, 582, 618,621, 722, 742, $743,775,824,960,1018,1032,1291,1379,1590,1592,1702,1741$, 1770

Gilman Sandstone: 621

Glen Canyon Group: $116,580,581,582,1032$

Green River Formation: 7, 116, 159, 211, 282, 307, 308, 742, 743, 824, $886,900,1379,1590,1702$

Hermosa Formation: $622,722,775,1766$

Honaker Trail Formation: $622,722,775$

Ignacio Quartzite: 622

Jurassic System: 6, 580，581，582，785，1091，1245，1246，1379, 1731, $1741,1766,1823$

Kayenta Formation: $159,580,1032$

Leadville Limestone: $6,116,621,622,742,743,824,1766$

Lithologic logs: 7, 308, 621, 1032, 1741

Lodore Formation: 622

Lower Permian Series: 230

Madison Limestone: 621,622

Mancos Shale: $159,282,580,581,582,1032,1042,1741,1835$

Maroon Formation: $622,1706,1707$ 
Mesaverde Group: 116, 158, 159, 282, 501, 502, 580, 581, 582, 649, 900, $1042,1234,1702,1741,1835,1837$

Mesozoic Erathem: 580, 581, 582, 1340, 1592, 1597, 1599, 1750, 1751

Middle Jurassic Series: 1246, 1254

Minturn Formation: 622, 1707

Mississippian System: 6, 618, 619, 620,621, 722, 1018, 1091, 1706, 1731, 1766,1784

Moenkopi Formation: 580, 581, 582, 1712

Molas Formation: 622,775

Morgan Formation: 622,1707

Morrison Formation: $159,580,581,582,785,1032,1310,1311$

Navajo Sandstone: 580

Ohio Creek Formation: 1702

Ordovician System: $618,619,620,1018,1784$

Ouray Limestone: $6,622,1766$

Paleocene Series: 1702

Paleozoic Erathem: 618, 619, 620, 622, 1018, 1340, 1379, 1505, 1592, $1597,1599,1784$

Paonia Shale Member of Mesaverde Formation: 1741

Parachute Creek Member of Green River Formation: 7, 211, 307, 886, 1379, 1590

Paradox Member of Hermosa Formation: 622, 722, 775, 1766

Park City Formation: 622

Pennsylvanian System: 6, 618, 619,620,622, 722, 1018, 1073, 1091, $1379,1706,1707,1731,1766,1780,1781,1784$

Permian System: 6, 618, 619,620, 622, 722, 1018, 1073, 1091, 1379, $1505,1706,1707,1731,1765,1780,1781,1784$

Pinkerton Trail Formation: 622, 722, 775

Precambrian Erathem: 6, 159, 248, 1018, 1032, 1091, 1340, 1379, 1731, 1766

Price River Formation: 502

Quaternary System: 6, 282, 1091, 1379, 1702, 1731, 1741

Rico Formation: 622

Rollins Sandstone Member of Mesaverde Formation: 1741

San Rafael Group: 582, 1032, 1823

Sawatch Sandstone Formation: 622, 1784

Silurian System: 619,1018

State Bridge Formation: 622

Summerville Formation: 580, 785, 1032

Sundance Formation: 580

Terrace deposits: 1032

Tertiary System: $6,559,896,897,898,899,1091,1379,1592,1597$, $1599,1731,1741,1766$

Triassic System: 6, 446, 580, 581, 582, 1091, 1379, 1712, 1731, 1741, 1766

Uinta Formation: $7,159,211,742,743,824,1379,1590$

Uinta Mountain Group: 622

Upper Cretaceous Series: $501,570,890,896,897,898,1234,1833$

Upper Triassic Series: 446

Valley-fill deposits: 116

Wanakah Formation: 159

Wasatch Formation: $7,159,211,307,427,900,1702,1741$

Water levels: $4,7,158,159,580,621,1032,1091,1124,1311,1340$, $1702,1746,1751,1766$ 
Water-quality analyses: $4,7,64,159,211,282,307,308,528,621$, $722,742,743,960,1032,1311,1701,1702,1731,1746,1766$

Weber Sandstone: 622,1707

Wingate Sandstone: $116,159,580,767,849,850,1032$

Mesaverde Group: $5,8,116,129,130,147,148,149,150,156,157,158,159$, $171,212,282,287,288,311,339,354,402,405,501,502,506$, $545,580,581,582,585,594,610,630,632,633,634,649,778$, $792,826,836,865,885,889,891,893,900,901,903,915,948$, $949,1000,1005,1006,1007,1008,1009,1010,1038,1039,1040$, $1041,1042,1043,1044,1071,1081,1082,1125,1211,1212,1229$, $1230,1234,1241,1307,1339,1356,1423,1432,1473,1507,1532$, $1542,1572,1700,1702,1730,1741,1774,1835,1837,1846$

Aquifer tests: 836,1572

Dissolved solids: $5,116,147,148,149,157,159,212,282,354,582$, $630,632,792,826,836,1339,1572,1700,1702$

Drill-stem tests: 1700,1702

Geologic sections: $157,158,159,582,585,1071,1339,1572,1702$, 1741

Hydraulic conductivity: $580,581,582,630,632,792,836,1473,1572$

Lithologic logs: $150,792,836,1339,1741$

Porosity: $580,581,792$

Storage coefficient or specific yield: $582,836,1473,1572$

Transmissivity: $582,630,836,1572$

Water levels: $5,156,157,158,159,354,580,630,632,792,826,836$, 1339,1702

Water-quality analyses: $5,147,148,149,156,157,159,212,282,354$, $630,632,792,826,836,1339,1572,1700,1702$

Mesozoic Erathem: $125,337,360,423,580,581,582,1077,1078,1178,1340$, $1452,1592,1596,1597,1599,1606,1750,1751,1752$

Dissolved solids: $360,582,1340$

Drill-stem tests: 1599

Geologic sections: 582, 1592

Hydraulic conductivity: $580,581,582,1599,1750$

Lithologic logs: 360

Porosity: $580,581,1750$

Storage coefficient or specific yield: 582,1340

Transmissivity: 582,1750

Water levels: $360,580,1340,1751$

Methane: 8

Water-quality analyses: 360

Mexican Cut Research Preserve: 104

Middle Dry Fork: 882

Middle Jurassic Series: $939,1246,1249,1252,1254,1386,1549$

Middle Park: 83, 120, 369, 553, 644, 674, 759, 771, 838, 846, 984, 1080, $1092,1110,1188,1328,1343,1622,1637,1699,1756,1790,1805$

Middle Park Formation: 846, 1166

Middle Pennsylvanian Series: 145, 776, 1014, 1016, 1099, 1169, 1448, 1449, $1451,1531,1570$

Miller Creek basin: 144

Mineral County: $36,38,39,64,76,234,296,323,362,514,515,516,528$, $552,722,742,743,816,824,994,1023,1091,1124,1291,1312$, $1315,1340,1378,1379,1432,1510,1511,1557,1558,1561,1565$, $1566,1701,1726$ 
Alluvium, undifferentiated: ' 742, 743, 824

Cambrian System: 722, 1091

Cenozoic Erathem: 1340

Creede Formation: 76

Cretaceous System: 1091, 1379

Dakota Group: $362,1291,1432$

Devonian System: 1091

Dissolved solids: $64,722,742,743,1340$

Fruitland Formation: 1432

Geologic sections: $722,742,743,824,1291,1379$

Geophysical logs: 722, 742, 743, 824, 1291, 1379

Green River Formation: 742, 743, 824, 1379

Hermosa Formation: 722

Honaker Trail Formation: 722

Jurassic System: 1091, 1379

Leadville Limestone: $742,743,824$

Mesaverde Group: 1432

Mesozoic Erathem: 1340

Miocene Series: 234

Mississippian System: 722, 1091

Paleozoic Erathem: 1340,1379

Parachute Creek Member of Green River Formation: 1379

Paradox Member of Hermosa Formation: 722

Pennsylvanian System: 38, 39, 722, 1091, 1379, 1726

Permian System: 722, 1091, 1379

Pinkerton Trail Formation: 722

Precambrian Erathem: 1091, 1340, 1379

Quaternary System: 1091, 1379

Tertiary System: 1091, 1379

Triassic System: 1091, 1379

Uinta Formation: $742,743,824,1379$

Water levels: $362,394,1091,1124,1340$

Water-quality analyses: $64,528,552,722,742,743,1701$

Mines: $15,55,72,86,122,161,163,189,216,317,330,331,365,382,392$, $397,400,408,477,502,515,524,526,551,556,558,591,605,624$, $626,629,637,696,703,723,724,725,755,760,770,854,858,927$, $964,981,987,1004,1029,1048,1063,1072,1092,1093,1098,1139$, $1143,1146,1161,1216,1299,1341,1342,1352,1360,1435,1454,1487$, $1533,1544,1590,1602,1632,1669,1686,1687,1697,1708,1740,1741$, 1787

Mine drainage: 551,1590

Mineralogy: $55,122,216,331,383,477,526,723,724,725,755,964,987$, $1004,1029,1048,1098,1216,1299,1454,1697,1740,1787$

Mining: $55,158,162,400,402,572,591,592,609,637,816,916,935,936$, $958,968,1022,1054,1062,1241,1263,1299,1563,1590,1593,1696$ Minnie Gulch: 1460

Minturn: $183,831,1046,1499,1638,1652$

Minturn Formation: $80,118,119,144,409,622,631,699,802,832,911$, $1016,1019,1049,1099,1172,1173,1450,1451,1499,1617,1707$, 1711

Dissolved solids: 631,699

Hydraulic conductivity: 622

Porosity: 622

Water-quality analyses: 631,699 
Miocene Series: 234, 630, 788, 1064, 1066

Dissolved solids: 630

Hydraulic conductivity: 630

Transmissivity: 630

Water levels: 630

Water-quality analyses: 630

Mississippian System: 6, 24, 25, 80, 81, 293, 340, 348, 406, 408, 410, 422, $547,617,618,619,620,621,722,769,800,1018,1091,1111,1118$, $1119,1209,1439,1524,1581,1706,1731,1766,1784,1811$

Aquifer tests: 621,1581

Dissolved solids: $617,621,722,1018,1582,1731,1766$

Drill-stem tests: 1766

Geologic sections: $617,618,621,722,1018$

Geophysical logs: 620,1784

Hydraulic conductivity: $617,619,620,621$

Lithologic logs: 617, 621

Porosity: 619, 620, 1784

Storage coefficient or specific yield: 621

Transmissivity: $619,621,1581$

Water levels: $617,621,1091,1581,1766$

Water-quality analyses: $617,621,722,1581,1731,1766$

Models: $48,49,50,91,97,297,361,400,447,485,509,525,585,586,602$, $915,959,968,1006,1008,1076,1165,1241,1341,1377,1445,1474$,

$1494,1495,1536,1550,1551,1588,1589,1590,1605,1732,1744,1826$, 1827

Moenkopi Formation: 215, 541, 580, 581, 582, 792, 1581, 1712

Aquifer tests: 1581

Dissolved solids: $541,582,792,1581$

Geologic sections: 541,582

Hydraulic conductivity: $580,581,582,792$

Lithologic logs: 792

Porosity: $580,581,792$

Storage coefficient or specific yield: 582

Transmissivity: 582,1581

Water levels: $541,580,792,1581$

Water-quality analyses: $541,792,1581$

Moffat County: $2,3,45,46,61,64,72,79,92,93,94,116,135,136,138$, $139,141,149,166,167,168,169,170,171,172,215,220,222$, $223,236,237,238,303,314,328,367,368,387,390,422,428$, $442,464,465,468,469,470,498,512,528,580,581,582,589$, $606,607,618,619,620,621,622,632,646,650,651,678,679$, $695,701,702,704,711,712,713,715,716,717,718,719,720$, $729,742,743,750,763,787,788,791,792,797,799,819,824$, $832,834,844,847,863,864,865,886,895,899,904,905,923$, $924,938,948,949,950,951,961,962,964,996,997,1018,1028$, $1065,1066,1084,1091,1094,1107,1118,1119,1124,1126,1135$, $1136,1151,1162,1163,1164,1171,1181,1184,1201,1236,1237$, $1291,1305,1312,1318,1319,1330,1340,1344,1346,1347,1349$, $1367,1368,1370,1372,1373,1374,1375,1376,1379,1392,1393$, $1411,1412,1417,1418,1419,1421,1422,1428,1429,1430,1431$, $1438,1447,1469,1470,1482,1506,1507,1552,1553,1554,1555$, $1572,1581,1597,1599,1607,1608,1630,1642,1643,1674,1675$, $1676,1677,1731,1738,1739,1750,1751,1784$ 
Alluvium, undifferentiated: $149,621,632,742,743,792,824,1581$ Aquifer tests: $621,1572,1581$

Belden Formation: 622

Browns Park Formation: 149, 468, 632, 788, 792, 1065, 1066, 1581

Burro Canyon Formation: 792

Cambrian System: 618,619,620,763, 1018, 1091, 1784

Carmel Formation: $580,581,1581$

Cedar Mountain Formation: 580, 581, 582, 1581

Cenozoic Erathem: 1340

Chaffee Formation: 621

Chinle Formation: $580,581,582,792,1372,1581$

Cretaceous System: 220, 498, 580, 581, 582, 695, 787, 834, 899, 949, $961,1028,1091,1181,1367,1372,1379,1507,1731$

Curtis Formation: $580,792,1581$

Cutler Formation: 622

Dakota Group: $116,141,580,581,582,792,961,1291,1581$

Devonian System: 618, 619,620,621, 1018, 1091, 1784

Dissolved solids: $64,116,149,442,582,621,632,742,743,791,792$, $1018,1340,1572,1581,1731$

Douglas Creek Member of Green River Formation: 886

Drill-stem tests: 1599

Duchesne River Formation: 791, 792

Dyer Dolomite Member of Chaffee Formation: 621

Eagle Valley Evaporite or Formation: 622, 1094

Elbert Formation: 622

Entrada Sandstone: $116,580,581,792,1581$

Eocene Series: $632,886,1421,1422$

Fort Union Formation: 149, 632, 787

Fox Hills Sandstone: 787, 834

Frontier Formation or Frontier Sandstone Member of Mancos Shale: 1184

Garden Gulch Member of Green River Formation: 886

Geologic sections: $582,618,621,742,743,824,1018,1291,1379,1572$

Geophysical logs: $582,618,621,742,743,824,1018,1291,1379,1572$

Gilman Sandstone: 621

Glacial deposits: 791

Glen Canyon Group: 116, 580, 581, 582, 792, 1581

Green River Formation: 116, 428, 470, 742, 743, 792, 824, 886, 964 , $1379,1421,1422$

Hermosa Formation: 622

Honaker Trail Formation: 622

Ignacio Quartzite: 622

Iles Formation: $149,632,1372,1506,1507,1572$

Jurassic System: 135, 136, 580, 581, 582, 1091, 1305, 1379, 1731

Kayenta Formation: 580

Lance Formation: $149,632,787,834$

Laney Member of Green River Formation: 964

Leadville Limestone: $116,621,622,742,743,824$

Lewis Shale: $149,632,834,1572$

Lithologic logs: 621,792

Lodore Formation: $622,763,1581$

Madison Limestone: $621,622,792$

Mancos Shale: $135,136,149,469,580,581,582,632,792,948,949$, 1184,1581 
Maroon Formation: 622

Mesaverde Group: 116, 149, 171, 580, 581, 582, 632, 792, 865, 948, 949, 1507,1572

Mesozoic Erathem: 580, 581, 582, 1340, 1597, 1599, 1750, 1751

Minturn Formation: 622, 832

Miocene Series: 788, 1066

Mississippian System: 422, 618, 619,620,621, 1018, 1091, 1118, 1119, $1581,1731,1784$

Moenkopi Formation: 215, 580, 581, 582, 792, 1581

Molas Formation: 622

Morgan Formation: 622, 792, 1581

Morrison Formation: $580,581,582,729,792,1581$

Mowry Shale: 1184

Navajo Sandstone: 580

Ohio Creek Formation: 834

Oligocene Series: 788

Ordovician System: $618,619,620,1018,1784$

Ouray Limestone: 622

Paleozoic Erathem: $618,619,620,622,847,1018,1340,1379,1597$, 1599,1784

Parachute Creek Member of Green River Formation: 886, 1379

Paradox Member of Hermosa Formation: 622

Park City Formation: 622, 792, 1581

Pennsylvanian System: $618,619,620,622,832,1018,1091,1379,1677$, 1731,1784

Permian System: 618, 619,620, 622, 847, 1018, 1091, 1330, 1379, 1447, 1731,1784

Permian and Pennsylvanian Systems: 589

Pierre Shale: 949

Pinkerton Trail Formation: 622

Precambrian Erathem: 720, 1018, 1091, 1340, 1379, 1731

Quaternary System: $1091,1379,1731$

Rico Formation: 622

Salt Wash Sandstone Member of Morrison Formation: 729

San Rafael Group: 582, 1581

Sawatch Sandstone Formation: 622, 1784

Silurian System: 619,1018

State Bridge Formation: 622

Summerville Formation: 580

Sundance Formation: 580

Terrace deposits: 1581

Tertiary System: $45,632,787,834,899,1065,1091,1379,1421,1422$, $1597,1599,1731$

Triassic System: 580, 581, 582, 1091, 1379, 1447, 1731

Trout Creek Sandstone Member of Iles Formation: 1506, 1507, 1572

Twentymile Sandstone Member of Williams Fork Formation: 1506, 1507, 1572

Uinta Formation: $742,743,791,792,824,1379$

Uinta Mountain Group: 622, 792, 1581

Upper Cretaceous Series: 45, 46, 171, 787, 865, 948, 949, 962, 1184, $1372,1506,1507$

Upper Jurassic Series: 729

Valley-fill deposits: 116,632

Wasatch Formation: 149, 632, 787, 792, 1421, 1422 
Water levels: $442,580,621,632,790,792,1091,1124,1340,1581,1751$ Water-quality analyses: $64,149,442,528,621,632,742,743,791,792$, $1572,1581,1731$

Weber Sandstone: $589,622,791,792,1581$

Williams Fork Formation: 149, 171, 632, 1372, 1507, 1572

Wingate Sandstone: 116,580

Moffat Tunnel: 1188

Molas Formation: $37,147,157,622,775,853,1159$

Dissolved solids: 147,157

Geologic sections: 157,775

Geophysical logs: 775

Hydraulic conductivity: 622

Porosity: 622

Water levels: 157

Water-quality analyses: 147,157

Molas Lake: 1538

Molas Pass: 37

Molina: 434

Monarch Valley: 837

Monitoring: 104,318

Montezuma: $418,1047,1215,1216$

Montezuma County: $22,30,38,53,60,64,82,107,117,131,134,150,151$, $157,212,214,309,313,321,323,337,348,358,362,393,417$, $421,476,486,487,488,489,490,491,492,493,494,495,496$, $528,529,532,554,567,580,581,582,584,585,617,619,620$, $622,662,663,669,722,733,734,739,742,743,775,795,796$, $804,805,810,811,813,814,824,826,836,929,1018,1035,1071$, $1072,1077,1091,1095,1124,1176,1291,1312,1334,1335,1340$, $1379,1432,1456,1585,1597,1599,1604,1605,1631,1723,1724$, $1731,1750,1751,1766,1775,1776,1777,1778,1779,1784,1802$, $1836,1839,1843$

Alluvium, flood plain: 151, 826

Alluvium, terrace: 826

Alluvium, undifferentiated: $150,157,742,743,824,826,836,1766$

Animas Formation: $150,151,157,212,826$

Aquifer tests: 836

Belden Formation: 622

Bluff Sandstone: 585

Burro Canyon Formation: 30, 150, 151, 836, 1605

Cambrian System: $348,617,619,620,722,1018,1091,1766,1784$

Carmel Formation: 580, 581, 1605

Cedar Mountain Formation: $580,581,582$

Cenozoic Erathem: 337, 1340

Chinle Formation: 580, 581, 582, 1605

Cliff House Sandstone: $150,151,157,212,532,585,826,836$

Cretaceous System: $30,131,580,581,582,585,617,804,1091,1379$, $1731,1766,1836$

Curtis Formation: 580

Cutler Formation: $157,622,775$

Dakota Group: $30,150,151,157,212,362,393,580,581,582,585,836$, $1291,1432,1605$

Devonian System: $348,617,619,620,1018,1091,1766,1784$

Dissolved solids: $64,157,212,582,617,722,742,743,826,836,1018$, $1340,1731,1766$ 
Dolores Formation: 107, 157

Drill-stem tests: 1599, 1766

Eagle Valley Evaporite or Formation: 622

Elbert Formation: 622, 1766

Entrada Sandstone: $580,581,585,836,1071,1605$

Fruitland Formation: 150, 151, 157, 212, 826, 836, 1176, 1432

Geologic sections: $157,393,582,585,617,722,742,743,775,824$, $1018,1071,1291,1379,1605$

Geophysical logs: 157, 393, 582, 585, 617, 722, 742, 743, 775, 824, $1018,1071,1291,1379,1605$

Glen Canyon Group: $580,581,582,836$

Green River Formation: 742, 743, 824, 1379

Hermosa Formation: $157,336,622,722,775,1766$

Honaker Trail Formation: 622, 722, 775

Ignacio Quartzite: 622

Intrusive rocks: 157

Junction Creek Sandstone: 836, 1605

Jurassic System: $580,581,582,585,617,795,1091,1379,1731,1766$

Kayenta Formation: 580, 1605

Kirtland Shale: $150,151,157,212,826,836,1176$

Leadville Limestone: $622,742,743,824,1766$

Lewis Shale: $150,151,157,212,826,836,1176$

Lithologic logs: $150,151,617,836$

Lodore Formation: 622

Lower Cretaceous Series: 496

Madison Limestone: 622

Mancos Shale: $150,151,157,212,580,581,582,585,826,836,1176$, 1605

Maroon Formation: 622

McDermott Member of Animas Formation: 836

Menefee Formation: $150,151,157,212,585,826,836,1176$

Mesaverde Group: $150,157,212,580,581,582,585,826,836,1071,1432$

Mesozoic Erathem: $337,580,581,582,1077,1340,1597,1599,1750,1751$

Minturn Formation: 622

Mississippian System: $348,617,619,620,722,1018,1091,1731,1766$, 1784

Moenkopi Formation: $580,581,582$

Molas Formation: $157,622,775$

Morgan Formation: 622

Morrison Formation: $150,151,157,212,358,393,580,581,582,585$, $836,1071,1605$

Navajo Sandstone: $580,836,1605$

Niobrara Formation: 1176

Ordovician System: $619,620,1018,1784$

Ouray Limestone: 622,1766

Paleozoic Erathem: 619, 620, 622, 1018, 1095, 1340, 1379, 1597, 1599, 1784

Parachute Creek Member of Green River Formation: 1379

Paradox Member of Hermosa Formation: 622, 722, 775, 1766

Park City Formation: 622

Pennsylvanian System: $38,134,617,619,620,622,722,1018,1091$, $1379,1631,1731,1766,1778,1779,1784$

Permian System: $617,619,620,622,722,1018,1091,1379,1631,1731$, 1766,1784 
Pictured Cliffs Sandstone: 150, 151, 157, 532, 826, 836, 1176

Pinkerton Trail Formation: 622, 722, 775

Point Lookout Sandstone: 150, 151, 157, 212, 585, 836, 1176

Precambrian Erathem: 617, 1018, 1091, 1340, 1379, 1731, 1766

Quaternary System: 617, 1091, 1379, 1731

Rico Formation: 157,622

San Jose Formation: 150, 151, 157, 212, 826

San Rafael Group: 582, 836

Sawatch Sandstone Formation: 622, 1784

Silurian System: 619, 1018

State Bridge Formation: 622

Summerville Formation: 580, 585, 836

Sundance Formation: 580

Terrace deposits: $150,151,157$

Tertiary System: $617,1071,1077,1091,1379,1597,1599,1731,1766$

Todilto Formation: 585

Triassic System: 580, 581, 582, 617, 1091, 1379, 1731, 1766, 1775

Uinta Formation: $742,743,824,1379$

Uinta Mountain Group: 622

Upper Cretaceous Series: 1176

Upper Jurassic Series: 496

Valley-fill deposits: 826,1071

Wanakah Formation: $150,151,1605$

Water levels: $157,362,580,617,826,836,1091,1124,1340,1751,1766$

Water-quality analyses: $64,157,212,393,528,617,722,742,743,826$, $836,1731,1766$

Weber Sandstone: 622

Wingate Sandstone: 580,1605

Montrose: $329,641,1560,1655$

Montrose County: $4,6,30,53,64,112,116,159,163,230,239,240,241$, $242,243,244,245,248,259,263,266,274,276,278,279,282$, $298,327,329,360,413,414,415,445,528,556,580,581,582$, $588,619,620,622,641,664,665,666,668,676,682,688,691$, $708,710,722,742,743,772,773,775,824,859,860,960,1018$, $1091,1108,1109,1113,1116,1124,1134,1137,1147,1190,1223$, $1249,1252,1266,1291,1311,1312,1340,1379,1432,1462,1500$, $1501,1502,1512,1549,1560,1575,1597,1599,1604,1655,1716$, $1717,1731,1750,1751,1761,1763,1766,1784,1802,1806,1807$, $1808,1809,1823,1830$

Alluvium, undifferentiated: $159,742,743,824,1147,1766$

Belden Formation: 622

Burro Canyon Formation: 30, 159

Cambrian System: 6, 619, 620, 722, 1018, 1091, 1766, 1784

Carmel Formation: 580,581

Cedar Mountain Formation: $580,581,582$

Cenozoic Erathem: 1340

Chinle Formation: $159,445,580,581,582$

Cretaceous System: 6, 30, 580, 581, 582, 1091, 1379, 1731, 1766

Curtis Formation: 580

Cutler Formation: 622, 775

Dakota Group: $30,116,159,580,581,582,1147,1291,1432$

Devonian System: 6, 619,620, 1018, 1091, 1766, 1784

Dissolved solids: $4,64,116,159,282,360,582,722,742,743,960$, $1018,1147,1311,1340,1731,1766$ 
Drill-stem tests: 1599,1766

Eagle Valley Evaporite or Formation: 622

Elbert Formation: 6, 622, 1766

Entrada Sandstone: $116,159,580,581,1549$

Fruitland Formation: 1432

Geologic sections: $159,582,722,742,743,775,824,960,1018,1147$, 1291,1379

Geophysical logs: 159, 582, 722, 742, 743, 775, 824, 960, 1018, 1147, 1291,1379

Glen Canyon Group: $116,580,581,582$

Green River Formation: $116,159,282,742,743,824,1379$

Hermosa Formation: 622, 722, 775, 1766

Honaker Trail Formation: 622, 722, 775

Ignacio Quartzite: 622

Jurassic System: 6, 580, 581, 582, 1091, 1249, 1252, 1379, 1549, 1731, 1766,1823

Kayenta Formation: 159,580

Leadville Limestone: 6, 116, 622, 742, 743, 824, 1766

Lithologic logs: 360,1147

Lodore Formation: 622

Lower Permian Series: 230

Madison Limestone: 622

Mancos Shale: $159,282,580,581,582,1147$.

Maroon Formation: 622

Mesaverde Group: $116,159,282,580,581,582,1432$

Mesozoic Erathem: 360, 580, 581, 582, 1340, 1597, 1599, 1750, 1751

Middle Jurassic Series: 1249, 1252, 1549

Minturn Formation: 622

Mississippian System: 6, 619,620,722, 1018, 1091, 1731, 1766, 1784

Moenkopi Formation: $580,581,582$

Molas Formation: 622,775

Morgan Formation: 622

Morrison Formation: $112,159,580,581,582,1147,1223,1252,1311$, 1512

Navajo Sandstone: 580

Ordovician System: $619,620,1018,1784$

Ouray Limestone: $6,622,1766$

Paleozoic Erathem: 298, 360, 619, 620, 622, 1018, 1340, 1379, 1597, 1599,1784

Parachute Creek Member of Green River Formation: 1379

Paradox Member of Hermosa Formation: 622, 722, 775, 1766

Park City Formation: 622

Pennsylvanian System: 6, 619,620,622, 722, 1018, 1091, 1379, 1731, 1766,1784

Permian System: 6, 619,620, 622, 722, 1018, 1091, 1379, 1731, 1765, 1784

Pinkerton Trail Formation: 622, 722, 775

Precambrian Erathem: $6,159,248,1018,1091,1340,1379,1731,1766$

Quaternary System: 6, 282, 360, 1091, 1379, 1731

Rico Formation: 622

Salt Wash Sandstone Member of Morrison Formation: 112, 1512

San Rafael Group: 582, 1249, 1252, 1823

Sawatch Sandstone Formation: 622, 1784

Silurian System: 619,1018 
State Bridge Formation: 622

Summerville Formation: 580

Sundance Formation: 580

Tertiary System: 6, 360, 1091, 1266, 1379, 1597, 1599, 1731, 1766

Triassic System: 6, 445, 580, 581, 582, 1091, 1379, 1731, 1766

Uinta Formation: $159,742,743,824,1379$

Uinta Mountain Group: 622

Upper Triassic Series: 445

Valley-fill deposits: 116

Wanakah Formation: 159,1549

Wasatch Formation: 159

Water levels: $4,159,360,580,1091,1124,1147,1311,1340,1751,1766$

Water-quality analyses: $4,64,159,282,360,528,722,742,743,960$, $1311,1731,1766$

Weber Sandstone: 622

Wingate Sandstone: $116,159,580$

Monument Butte: 701

Monument upwarp: 1570

Moqui: 494,805

Morgan Formation: $411,622,792,1581,1707$

Aquifer tests: 1581

Dissolved solids: 792,1581

Hydraulic conductivity: 622, 792

Lithologic logs: 792

Porosity: 622, 792

Transmissivity: 1581

Water levels: 792,1581

Water-quality analyses: 792,1581

Morrison Formation: $5,29,112,115,125,147,148,150,151,157,159,212$, $216,358,359,393,541,580,581,582,585,599,630,699,729$, $785,792,836,1032,1071,1089,1147,1166,1223,1252,1301,1302$, $1304,1310,1311,1452,1512,1581,1602,1605,1632,1658,1740$, 1787

Aquifer tests: $836,1032,1581$

Dissolved solids: $5,115,147,148,157,159,212,541,582,630,699$, $792,836,1032,1147,1311,1581$

Geologic sections: 157, 159, 393, 541, 582, 585, 1032, 1071, 1147, 1605

Hydraulic conductivity: $580,581,582,630,792,836,1032$

Lithologic logs: $115,150,151,792,836,1032,1147$

Porosity: $580,581,792,1032$

Storage coefficient or specific yield: 582, 836, 1032

Transmissivity: $582,630,836,1032,1581$

Water levels: $5,115,157,159,541,580,630,792,836,1032,1147$, 1311,1581

Water-quality analyses: $5,115,147,148,157,159,212,393,541,630$,

Mosca: 992 $699,792,836,1032,1311,1581$

Mount Axtell: 610

Mount Blaine: 685

Mount Garfield: 1042

Mount Garfield Formation: 412

Mount Gunnison: 1241

Mount Guyot: 1477 
Mount Harris: 1420,1423

Mount Harvard: 146, 1053

Mount Hope Caldera: 561

Mount Jackson: 1714

Mount Lincoln: 1640

Mount Manitou: 1522

Mount Richthofen: 1242

Mount Sherman: 81

Mowry Shale: 1184

Nacimiento Formation: 535

Nahcolite: 572

Natural gas: $8,29,287,288,300,536,539,891,893,922,999,1005,1006$, $1007,1008,1010,1039,1040,1041,1125$

Naturita: 274

Navajo Sandstone: $578,580,836,1314,1605$

Aquifer tests: 836

Dissolved solids: 836

Geologic sections: 1605

Hydraulic conductivity: 580, 836

Lithologic logs: 836

Porosity: 580

Storage coefficient or specific yield: 836

Transmissivity: 836

Water levels: 580,836

Water-quality analyses: 836

Needle Mountains: 57, 197, 375, 640, 726, 1159, 1454, 1600

New Castle: 1308

Ninemile Gap: $1236,1237,1375$

Niobrara Formation: 631, 1176

Dissolved solids: 631

Water-quality analyses: 631

No-Name: 1251

North Fork Gunnison River: 5, 919

North Mamm Peak: 438

North Thompson Creek: 633

Norwood: 1109

Nuclear explosions: 352, 1702

Nuclear waste: 775,1702

Oh-Be-Joyful: 613

Ohio Creek Formation: $608,630,834,901,1043,1222,1680,1681,1700,1702$, 1846

Dissolved solids: $630,1700,1702$

Drill-stem tests: 1700,1702

Geologic sections: 1702

Hydraulic conductivity: 630

Transmissivity: 630

Water levels: 630,1702

Water-quality analyses: $630,1700,1702$

Oil shale: $7,13,55,67,162,254,286,294,345,352,392,398,403,428$, $431,458,459,546,555,600,603,604,933,968,1021,1106,1250$, $1281,1321,1323,1390,1516,1518,1519,1577,1579,1587,1589$, $1590,1592,1628,1661,1696,1709,1847$ 
Oligocene Series: $113,547,630,788,1522$

Dissolved solids: 630

Hydraulic conductivity: 630

Transmissivity: 630

Water levels: 630

Water-quality analyses: 630

Ordovician System: 547,618,619,620, 1018, 1296, 1425, 1784

Dissolved solids: 1018

Geologic sections: 618,1018

Geophysical logs: 620,1784

Hydraulic conductivity: 619,620

Porosity: 619, 620, 1784

Transmissivity: 619

Organics: $287,288,398,403,404,405,461,462,500,501,502,505,534$,

$536,539,545,586,596,600,609,635,645,922,968,1007,1013,1022$,

$1039,1230,1250,1284,1337,1371,1372,1432,1506,1507,1533,1579$,

$1592,1632,1696$

Ouray: $187,374,1062,1663,1842$

Ouray County: $4,6,25,26,64,107,116,187,191,194,323,327,329,330$, $414,415,416,528,552,580,581,582,619,620,622,641,682$, $688,691,692,722,742,743,806,809,824,927,930,1018,1055$, $1056,1057,1060,1061,1062,1063,1091,1109,1114,1124,1147$, $1291,1312,1340,1379,1432,1549,1560,1597,1599,1655,1663$, $1731,1750,1751,1753,1754,1755,1784,1830,1842$

Alluvium, undifferentiated: $742,743,824,1147$

Belden Formation: 622

Cambrian System: 6,619,620, 722, 1018, 1091, 1784

Carmel Formation: 580,581

Cedar Mountain Formation: $580,581,582$

Cenozoic Erathem: 1340

Chinle Formation: $580,581,582$

Cretaceous System: 6, 580, 581, 582, 1091, 1379, 1731

Curtis Formation: 580

Cutler Formation: 622

Dakota Group: $116,580,581,582,1147,1291,1432$

Devonian System: 6, 619,620, 1018, 1091, 1784

Dissolved solids: $4,64,116,582,722,742,743,1018,1147,1340,1731$

Dolores Formation: 107

Drill-stem tests: 1599

Eagle Valley Evaporite or Formation: 622

Elbert Formation: 6, 622

Entrada Sandstone: $116,580,581,1549$

Eocene Series: 1114

Fruitland Formation: 1432

Geologic sections: $582,722,742,743,824,1018,1147,1291,1379$

Geophysical logs: $582,722,742,743,824,1018,1147,1291,1379$

Glen Canyon Group: $116,580,581,582$

Green River Formation: 116, 742, 743, 824, 1379

Hermosa Formation: 622, 722

Honaker Trail Formation: 622, 722

Ignacio Quartzite: 622

Jurassic System: 6, 580, 581, 582, 1091, 1379, 1549, 1731

Kayenta Formation: 580 
Leadville Limestone: $6,25,26,116,622,742,743,824$

Lithologic logs: 1147

Lodore Formation: 622

Madison Limestone: 622

Mancos Shale: $580,581,582,1147$

Maroon Formation: 622

Mesaverde Group: $116,580,581,582,1432$

Mesozoic Erathem: 580, 581, 582, 1340, 1597, 1599, 1750, 1751

Middle Jurassic Series: 1549

Minturn Formation: 622

Mississippian System: 6, 25, 619,620, 722, 1018, 1091, 1731, 1784

Moenkopi Formation: $580,581,582$

Molas Formation: 622

Morgan Formation: 622

Morrison Formation: $580,581,582,1147$

Navajo Sandstone: 580

Ordovician System: $619,620,1018,1784$

Ouray Limestone: 6,622

Paleozoic Erathem: 619,620,622, 1018, 1340, 1379, 1597, 1599, 1784

Parachute Creek Member of Green River Formation: 1379

Paradox Member of Hermosa Formation: 622, 722

Park City Formation: 622

Pennsylvanian System: 6, 619, 620, 622, 722, 1018, 1091, 1379, 1731, 1784

Permian System: 6, 619,620,622, 722, 1018, 1091, 1379, 1731, 1784

Pinkerton Trail Formation: 622, 722

Pleistocene Series: 1114

Precambrian Erathem: 6, 1018, 1091, 1340, 1379, 1731

Quaternary System: 6, 1091, 1379, 1731

Rico Formation: 622

San Rafael Group: 582

Sawatch Sandstone Formation: 622, 1784

Silurian System: 619,1018

State Bridge Formation: 622

Summerville Formation: 580

Sundance Formation: 580

Tertiary System: $6,1091,1379,1597,1599,1731$

Triassic System: 6, 580, 581, 582, 1091, 1379, 1731

Uinta Formation: $742,743,824,1379$

Uinta Mountain Group: 622

Valley-fill deposits: 116

Wanakah Formation: 1549

Water levels: $4,580,1091,1124,1147,1340,1751$

Water-quality analyses: $4,64,528,551,722,742,743,1731$

Weber Sandstone: 622

Wingate Sandstone: 116,580

Ouray Limestone: 6, 622, 1766

Dissolved solids: 1766

Drill-stem tests: 1766

Hydraulic conductivity: 622

Porosity: 622

Water levels: 1766

Water-quality analyses: 1766 
Oxides: 114,1580

Pagoda: $938,1163,1164,1482$

Pagosa Hot Spring: 598

Pagosa Springs: 59, 1122, 1503

Pahlone Peak: 1262

Paleocene Series: 533, 537, 547, 639, 1508, 1700, 1702

Dissolved solids: 1700,1702

Drill-stem tests: 1700,1702

Geologic sections: 1702

Water levels: 1702

Water-quality analyses: 1700,1702

Paleoclimatology: $107,125,446,776,909,1073,1087$

Paleogeography: $24,26,30,35,43,291,337,389,395,446,535,570,800$, $847,886,889,906,907,908,910,911,912,1000,1014,1019,1039$, $1040,1073,1082,1083,1099,1303,1386,1448,1450,1790$

Paleozoic Erathem: 35, 37, 75, 88, 228, 231, 292, 298, 360, 409, 411, 609, $618,619,620,622,847,909,1018,1078,1095,1172,1173,1209$, $1297,1340,1379,1452,1505,1524,1592,1596,1597,1599,1606$, 1784

Dissolved solids: $360,1018,1340$

Drill-stem tests: 1599

Geologic sections: 618, 1018, 1379, 1592

Geophysical logs: 620,1784

Hydraulic conductivity: 619, 620, 622, 1599

Lithologic logs: 360

Porosity: 619,620,622, 1784

Storage coefficient or specific yield: 1340

Transmissivity: 619

Water levels: 360,1340

Water-quality analyses: 360

Pando: $80,1633,1634,1635,1638$

Paonia: 462, 503, 913, 914, 1620

Paonia Shale Member of Mesaverde Formation: 405, 1741

Geologic sections: 1741

Lithologic logs: 1741

Parachute Creek basin: 211, 403, 600, 1281

Parachute Creek Member of Green River Formation: 5, 7, 211, 307, 342, 352, $392,398,403,780,781,782,886,1020,1021,1322,1379,1404$, $1405,1444,1495,1590,1745,1748,1749,1771$

Aquifer tests: 352,392

Dissolved solids: $5,7,211,307,342,352,392,780,781,782,1020$, $1021,1444,1745,1749,1771$

Drill-stem tests: 780,1771

Geologic sections: 7, 211, 307, 398, 403, 780, 781, 782, 1379, 1404, $1405,1590,1745,1749$

Geophysical logs: $307,398,780,1745,1771$

Lithologic logs: 7, 352, 398, 780

Porosity: 781, 782

Storage coefficient or specific yield: 782, 1590, 1745, 1771

Transmissivity: $7,352,780,1771$

Water levels: $5,7,342,352,403,781,782,1745,1771$

Water-quality analyses: $5,7,211,307,342,352,392,780,781,782$, $1020,1021,1444,1745,1749,1771$ 
Paradox basin: $9,42,43,53,91,98,131,145,233,298,349,357,568,587$, $588,722,762,765,772,773,774,775,776,815,929,934,1113$, $1116,1127,1156,1169,1175,1177,1178,1440,1462,1531,1570$, $1583,1585,1632,1705,1736,1766,1791,1802,1815$

Dissolved solids: 722,1766

Drill-stem tests: 1766

Geologic map: 349

Geologic sections: 722,775

Geology: $9,43,53,98,131,145,233,298,349,357,568,588,762$, $765,773,776,934,1113,1156,1169,1440,1531,1570,1585,1632$, $1705,1736,1791,1802,1815$

Geomorphology: $98,357,774,775$

Geophysical logs: 775

Hydrology: 1766,1802

Model: 91

Organics: 1632

Stratigraphy: $98,762,774,776,815,934,1127,1156,1169,1178,1531$, $1583,1585,1632$

Tectonics: $42,929,1127,1570$

Water levels: 1766

Water-quality analyses: 722,1766

Paradox Member of Hermosa Formation: 91, 145, 622, 722, 775, 1016, 1766

Dissolved solids: 722,1766

Drill-stem tests: 1766

Geologic sections: 722,775

Geophysical logs: 775

Hydraulic conductivity: 622

Porosity: 622

Water levels: 1766

Water-quality analyses: 722, 1766

Paradox Valley: $114,960,1183$

Park City Formation: 622, 792, 848, 1581

Aquifer tests: 1581

Dissolved solids: 792,1581

Hydraulic conductivity: 622, 792

Lithologic logs: 792

Porosity: 622, 792

Transmissivity: 1581

Water levels: 792,1581

Water-quality analyses: 791, 1581

Park Range: 1527, 1528

Parkview Mountain: 1535

Parsha11: 120

Parting Quartzite Member of Chaffee Formation: 229, 699, 1425, 1524

Dissolved solids: 699

Water-quality analyses: 699

Parvin Lake: 12

Peerless Formation: 630, 1296, 1297, 1425

Dissolved solids: 630

Hydraulic conductivity: 630

Transmissivity: 630

Water levels: 630

Water-quality analyses: 630 
Pennsylvanian System: $6,38,39,68,70,118,124,134,144,145,233,291$, $293,407,441,547,617,618,619,620,622,628,636,699,722$, $774,802,803,815,832,906,907,908,909,911,912,934,956$, $988,989,1014,1016,1018,1019,1073,1091,1097,1099,1127$, $1169,1172,1173,1204,1348,1379,1387,1448,1449,1450,1451$, $1499,1531,1538,1539,1570,1631,1638,1677,1684,1706,1707$, $1726,1731,1766,1778,1779,1780,1781,1784,1815$

Dissolved solids: $617,699,722,1018,1731,1766$

Drill-stem tests: 1766

Geologic sections: $617,618,722,1018,1379$

Geophysical logs: 620,1784

Hydraulic conductivity: $617,619,620,622$

Lithologic logs: 617

Porosity: $619,620,622,1784$

Transmissivity: 619

Water levels: 617, 1091,1766

Water-quality analyses: $617,699,722,1731,1766$

Permeability: $97,161,180,220,347,352,620,855,856,915,999,1044$, $1225,1532,1599,1700,1702,1767,1826$

Permian System: $6,34,40,44,70,411,441,547,593,617,618,619,620$, $622,628,722,815,847,906,907,908,910,911,912,956,988$, $989,1018,1019,1073,1091,1117,1172,1173,1330,1371,1379$, $1447,1481,1496,1497,1505,1631,1706,1707,1731,1766,1780$, 1781,1784

Dissolved solids: $617,722,1018,1731,1766$

Drill-stem tests: 1766

Geologic sections: $617,618,722,1018,1379$

Geophysical logs: 620,1784

Hydraulic conductivity: $617,619,620,622$

Lithologic logs: 617

Porosity: 619, 620,622, 1784

Transmissivity: 619

Water levels: $617,1091,1766$

Water-quality analyses: $617,722,1731,1766$

Permian and Pennsylvanian Systems: 69,589

Petroleum: 29, 233, 288, 870, 872, 891, 932, 956, 957, 1028, 1044, 1156, $1532,1705,1816$

Piceance basin: $7,13,14,23,31,55,99,103,140,162,171,224,256,257$, $7,301,302,392,398,404,405,430,458,460,467,502,506,550$, $570,572,586,645,648,649,683,689,723,724,725,877,879$, $880,881,883,886,889,890,891,892,893,896,897,898,899$, $901,903,908,912,920,944,968,1000,1007,1013,1038,1039$, $1040,1041,1043,1044,1067,1078,1081,1148,1157,1158,1196$, $1201,1221,1222,1230,1234,1244,1250,1307,1321,1322,1323$, $1394,1404,1405,1444,1448,1471,1494,1495,1516,1526,1530$, $1532,1579,1587,1588,1589,1590,1591,1592,1593,1595,1618$, $1626,1628,1681,1696,1706,1707,1730,1742,1743,1744,1745$, $1746,1749,1765,1770,1771,1812,1813,1837,1838,1846$

Aquifer tests: 392,1765

Dissolved solids: 7, 392, 550, 572, 944 1444, 1745, 1746, 1749, 1771 Drill-stem tests: 1771

Geohydrology: $586,883,944,968,1078,1148,1404,1444,1495,1579$, $1587,1589,1590,1591,1593,1595,1618,1745,1765,1770,1812$, 1838 
Geologic map: $31,502,1234$

Geologic sections: 7, 398, 572, 1404, 1405, 1590, 1592, 1742, 1745, 1749,1770

Geology: 13, 14, 31, 103, 171, 256, 287, 301, 398, 404, 405, 430, 458, $460,467,502,506,570,586,645,648,649,683,723,877,879$, $880,881,886,889,890,891,892,893,896,897,898,899,901$, $903,908,912,920,1000,1007,1013,1038,1039,1040,1041,1042$, $1044,1067,1078,1081,1157,1158,1196,1201,1221,1230,1244$, $1250,1307,1321,1322,1323,1394,1448,1471,1526,1530,1532$, $1579,1590,1591,1592,1593,1618,1626,1628,1696,1707,1730$, $1743,1745,1749,1770,1812,1837,1838$

Geomorphology: $301,724,725,880,881,896,897,898,899,901,1157$, $1323,1471,1812$

Geophysical logs: $398,1745,1746,1771$

Hydraulic conductivity: 1148

Hydrology: $13,14,99,392,586,883,944,968,1041,1078,1148,1404$, $1444,1494,1495,1579,1589,1590,1591,1596,1618,1742,1743$, $1744,1745,1749,1765,1770,1812,1838$

Lithologic logs: 7, 398

Model: $586,968,1494,1495,1588,1589,1590,1744$

Organics: $287,398,404,405,502,586,645,968,1007,1013,1039$, $1230,1250,1579,1592,1696$

Porosity: 1148

Storage coefficient or specific yield: 1148, 1590, 1745, 1771

Stratigraphy: $23,103,171,257,287,301,302,405,430,502,506,570$, $683,689,877,879,880,881,883,886,890,891,892,893,896$, $897,898,901,903,908,912,1000,1038,1039,1040,1043,1044$, $1078,1081,1221,1222,1230,1244,1250,1307,1322,1448,1526$, $1626,1628,1681,1707,1730,1837,1846$

Tectonics: $140,301,889,1707,1813$

Transmissivity: $7,550,1746,1765,1771$

Water levels: $7,550,1745,1746,1771$

Water-quality analyses: $7,392,550,944,1444,1745,1746,1749,1771$

Pictured Cliffs Sandstone: 147, 150, 151, 157, 532, 533, 536, 537, 539, 826, $836,1100,1101,1102,1176,1441$

Aquifer tests: 836

Dissolved solids: $147,157,826,836$

Geologic sections: 157

Hydraulic conductivity: 836

Lithologic logs: 150, 151, 836

Storage coefficient or specific yield: 836

Transmissivity: 836

Water levels: $157,826,836$

Water-quality analyses: $147,157,826,836$

Piedra River Canyon: 1362

Pierre Shale: $631,843,949,1080,1790$

Dissolved solids: 631

Water-quality analyses: 631

Pine Butte Member of Sundance Formation: 1386

Pine Mountain: 261, 275, 1670

Pine River Valley: 1365,1366

Pinedale Anticline: 1000,1040 
Pinkerton Trail Formation: $37,622,722,775$

Dissolved solids: 722

Geologic sections: 722,775

Geophysical logs: 775

Hydraulic conductivity: 622

Porosity: 622

Water-quality analyses: 722

Pitkin County: $64,69,70,116,148,174,175,176,177,178,179,180,181$, $182,184,228,229,282,311,312,325,329,424,446,500,501$, $528,530,574,575,576,577,580,581,582,611,618,619,620$, $621,622,633,638,641,661,703,730,742,743,760,783,807$, $824,830,831,890,899,910,935,936,976,981,990,991,1016$, $1018,1050,1052,1074,1075,1091,1094,1111,1124,1203,1207$, $1209,1291,1312,1326,1332,1340,1379,1387,1597,1599,1639$, $1653,1654,1655,1685,1688,1701,1707,1715,1731,1735,1750$, $1751,1772,1784,1822,1837$

Alluvium, undifferentiated: $148,179,621,661,742,743,824$

Aquifer tests: 621

Belden Formation: 622, 1387, 1707

Burro Canyon Formation: 148

Cambrian System: $618,619,620,1018,1091,1784$

Carmel Formation: 580,581

Cedar Mountain Formation: $580,581,582$

Cenozoic Erathem: 1340

Chaffee Formation: 621

Chinle Formation: $148,446,580,581,582$

Cretaceous System: $311,580,581,582,899,1091,1379,1731$

Curtis Formation: 580

Cutler Formation: 622

Dakota Group: $116,148,580,581,582,1291$

Devonian System: $618,619,620,621,730,1018,1091,1784$

Dissolved solids: $64,116,148,282,582,621,742,743,1018,1340$, 1731

Dockum Group: 446

Drill-stem tests: 1599

Dyer Dolomite Member of Chaffee Formation: 621

Eagle Valley Evaporite or Formation: 148, 622, 1016, 1094, 1707

Elbert Formation: 622

Entrada Sandstone: $116,148,580,581$

Geologic sections: $582,618,621,742,743,824,1018,1291,1379$

Geophysical logs: $582,618,621,742,743,824,1018,1291,1379$

Gilman Sandstone: 621

Glacial deposits: 179

Glen Canyon Group: 116, 580, 581, 582

Gothic Formation: 1016

Green River Formation: 116, 282, 742, 743, 824, 1379

Hermosa Formation: 622

Honaker Trail Formation: 622

Ignacio Quartzite: 622

Jurassic System: 580, 581, 582, 991, 1091, 1379, 1731, 1822

Kayenta Formation: 580

Leadville Limestone: $116,621,622,742,743,824$

Lithologic logs: 621

Lodore Formation: 622 
Madison Limestone: 621,622

Mancos Shale: 148, 282, 580, 581, 582, 633

Manitou Formation: 831

Maroon Formation: 148, 424, 622, 910, 990, 1016, 1707

Mesaverde Group: $116,148,282,311,501,580,581,582,633,1837$

Mesozoic Erathem: 580, 581, 582, 1340, 1597, 1599, 1750, 1751

Middle Pennsylvanian Series: 1016

Minturn Formation: 622, 1016, 1707

Mississippian System: 618, 619,620,621, 1018, 1091, 1111, 1209, 1731, 1784

Moenkopi Formation: $580,581,582$

Molas Formation: 622

Morgan Formation: 622, 1707

Morrison Formation: $148,580,581,582$

Navajo Sandstone: 580

Ordovician System: 618,619,620, 1018, 1784

Ouray Limestone: 622

Paleozoic Erathem: 228, 618, 619, 620, 622, 1018, 1209, 1340, 1379, $1597,1599,1784$

Parachute Creek Member of Green River Formation: 1379

Paradox Member of Hermosa Formation: 622, 1016

Park City Formation: 622

Parting Quartzite Member of Chaffee Formation: 229

Pennsylvanian System: $70,618,619,620,622,1016,1018,1091,1379$, $1387,1707,1731,1784$

Permian System: $70,618,619,620,622,910,1018,1091,1379,1707$, 1731,1784

Permian and Pennsylvanian Systems: 69

Pinkerton Trail Formation: 622

Precambrian Erathem: 1018, 1091, 1340, 1379, 1731

Quaternary System: 282, 1091, 1379, 1731

Rico Formation: 622

Robinson Limestone Member of Minturn Formation: 1016

San Rafael Group: 582, 1822

Sawatch Sandstone Formation: 622, 1784

Silurian System: 619, 1018

State Bridge Formation: 148, 575, 622, 910

Summerville Formation: 580

Sundance Formation: 580

Terrace deposits: 661

Tertiary System: $899,1091,1379,1597,1599,1731$

Triassic System: 446, 580, 581, 582, 1091, 1379, 1731

Uinta Formation: $742,743,824,1379$

Uinta Mountain Group: 622

Upper Cretaceous Series: 501, 890

Upper Triassic Series: 446

Valley-fill deposits: 116

Wasatch Formation: 148

Water levels: $580,621,661,1091,1124,1340,1751$

Water-quality analyses: $64,148,282,528,621,742,743,1701,1731$

Weber Sandstone: $148,424,622,1707$

Wingate Sandstone: 116,580

Placerville: 206, 207, 1549

Platoro: 1283 
Pleistocene Series: $247,310,672,1114,1385,1499$

Geologic sections: 247

Lithologic logs: 247

Water levels: 247

Plug Hat Rock: 1429

Point Lookout Sandstone: 147, 150, 151, 157, 212, 585, 820,836, 1176, 1825 Aquifer tests: 836

Dissolved solids: $147,157,212,836$

Geologic sections: 157,585

Hydraulic conductivity: 836

Lithologic logs: $150,151,836$

Storage coefficient or specific yield: 836

Transmissivity: 836

Water levels: 157,836

Water-quality analyses: $147,157,212,836$

Poison Ridge: 1213,1214

Pollution: $6,157,296,317,352,402,440,448,541,579,602,603,604$, $700,742,743,828,945,1013,1026,1076,1144,1145,1341,1342,1390$, $1474,1533,1550,1578,1579,1580,1629,1702,1720,1721,1731,1732$, $1794,1812,1826$

Pontiac Pit: 1086

Pony Express Limestone Member of Wanakah Formation: 1386

Porcupine Mountain: 1670

Porosity: 220, 403, 620, 999, 1044, 1225, 1532, 1784

Porphyry Mountain: 1052

Potentiomanometer: 1433

Powderhorn Wilderness: 1479

Precambrian crystalline rocks: 115

Dissolved solids: 115

Lithologic logs: 115

Water levels: 115

Water-quality analyses: 115

Precambrian Erathem: $1,6,10,11,35,37,43,57,159,197,248,335,479$, $480,547,598,609,617,630,631,699,720,726,744,749,822$, $1018,1032,1091,1340,1379,1457,1600,1645,1647,1731,1766$, 1769

Aquifer tests: 598,1032

Dissolved solids: $159,598,617,630,631,699,1018,1032,1340,1731$, 1766,1769

Drill-stem tests: 1766

Geologic sections: $159,598,617,1018,1032,1379$

Geophysical logs: 598

Hydraulic conductivity: $617,630,1032$

Lithologic logs: $598,617,1032,1769$

Porosity: 1032

Storage coefficient or specific yield: $598,1032,1340$

Transmissivity: $598,630,1032$

Water levels: $159,598,617,630,1032,1091,1340,1766,1769$

Water-quality analyses: $159,598,617,630,631,699,1032,1731,1766$, 1769

Price River basin: 448

Price River Formation: 405, 502, 1082

Project Rio Blanco: 952, 953, 954

Project Rulison: $1700,1701,1701$ 
Quartz Creek: 1511,1540

Quaternary System: 6, 156, 247, 282, 360, 598, 617, 635, 1086, 1087, 1091, $1339,1379,1385,1401,1499,1700,1702,1731,1741,1782,1783$, 1829

Aquifer tests: 598

Dissolved solids: $282,360,598,617,1339,1700,1702,1731$

Drill-stem tests: 1700,1702

Geologic sections: $247,598,617,1339,1379,1702,1741$

Geophysical logs: 598

Hydraulic conductivity: 617

Lithologic logs: $247,360,598,617,1339,1741$

Storage coefficient or specific yield: 598

Transmissivity: 598

Water levels: $156,247,360,598,617,1091,1339,1702$

Water-quality analyses: $156,282,360,598,617,1339,1700,1702,1731$

Rabbit Ears: 655

Radioactive Waste: $6,440,587,1802$

Radioactivity: 217, 295, 296, 904, 905,953, 1041, 1053, 1701

Radium: $614,1232,1464,1465$

Radon: 1232,1573

Ragged Mountain: 798

Rangely: $71,124,388,597,607,627,956,1212,1225,1226,1229,1543$, 1607,1608

Rangely Dome: 1543

Rangely field: . 124, 956

Ranger Warm Spring: 1841

Rapid Creek basin: 158

Rattlesnake Butte: 165, 1569

Raven Park Anticline: 124

Razor Creek Dome: 1268

Razorback Ridge: 1414

Recharge: $101,282,297,603,1068,1474,1515,1594,1605,1619,1773$

Reclamation: $163,402,828,1241,1732$

Recreation: 115,1769

Red Canyon: 84, 1134

Red Cliff: $86,365,532,533,629,1146,1352$

Red Creek Ranch: 1411

Red Dirt Creek: 851, 1492

Red Mesa: 60, 1529

Red Mountain: 334

Red Mountain district: 334

Red Sandstone Creek: 1172, 1173

Red Wash field: 957

Reed Wash: 945

Rico: 381, 383, 463, 1138, 1139, 1333, 1335, 1693, 1766

Rico Formation: $147,157,622,815,853$

Dissolved solids: 147,157

Geologic sections: 157

Hydraulic conductivity: 622

Porosity: 622

Water levels: 157

Water-quality analyses: 147, 157

Rico Mountains: 383, 1766

Ridgway: $692,1114,1753,1754,1755$ 
Rifle Gap: $633,885,1043,1081,1083,1680$

Rifle Mine: 122

Rio Blanco County: $7,15,31,55,61,64,67,71,116,121,124,127,135,141$, $144,161,162,170,171,211,213,220,224,225,228,236,237$, $249,250,251,252,253,254,255,257,282,302,307,308,325$, $328,340,342,343,344,352,386,387,388,390,392,398,405$, $429,431,442,446,452,453,454,455,456,457,458,460,464$, $467,469,470,528,541,550,572,580,581,582,588,597,601$, $606,607,618,619,620,621,622,625,627,632,646,649,677$, $678,679,680,681,683,684,687,689,690,693,694,702,729$, $742,743,752,779,780,781,782,791,792,819,824,832,876$, $877,878,879,880,881,883,886,889,890,892,893,895,899$, $901,909,912,932,942,943,944,945,949,952,953,954,956$, $957,961,968,974,1013,1018,1020,1021,1022,1041,1065,1067$, $1078,1091,1094,1106,1124,1148,1158,1196,1201,1202,1203$, $1220,1225,1226,1229,1230,1234,1237,1243,1244,1247,1250$, $1251,1255,1256,1278,1291,1312,1316,1317,1318,1319,1320$, $1321,1323,1339,1340,1354,1364,1368,1369,1371,1372,1373$, $1375,1376,1379,1394,1404,1405,1413,1414,1430,1431,1444$, $1450,1467,1482,1518,1520,1523,1525,1526,1530,1543,1544$, $1577,1579,1588,1590,1591,1592,1593,15971599,1607,1608$, $1618,1624,1628,1642,1643,1653,1654,1680,1682,1696,1704$, $1707,1731,1742,1744,1745,1746,1748,1749,1750,1751,1764$, $1765,1770,1771,1784,1788,1797,1821,1838,1846,1847$

Alluvium, undifferentiated: $7,307,308,342,621,625,632,742,743$, $781,782,792,824,1021,1106,1444,1682,1742,1745,1770$

Anvil Points Member of Green River Formation: 7, 211, 1444

Aquifer tests: $308,352,392,621,1682,1765$

Belden Formation: $622,912,1450,1707$

Bowie Shale Member of Mesaverde Formation: 405

Browns Park Formation: 632, 792, 1065, 1371

Burro Canyon Formation: 792

Cambrian System: 618, 619,620, 1018, 1091, 1784

Carmel Formation: 580,581

Cedar Mountain Formation: $580,581,582$

Cenozoic Erathem: 889,1340

Chaffee Formation: 621

Chinle Formation: 446, 541, 580, 581, 582, 792, 1372

Corcoran Member of Price River Formation: 405

Cozzette Member of Price River Formation: 405

Cretaceous System: 220, 580, 581, 582, 892, 893, 899, 949, 961, 1091, $1229,1230,1371,1372,1379,1543,1680,1731,1846$

Curtis Formation: 580,792

Cutler Formation: 622

Dakota Group: $116,141,580,581,582,792,961,1291$

Devonian System: $618,619,620,621,1018,1091,1784$

Dissolved solids: $7,64,116,211,282,307,308,342,343,344,352$, $392,442,541,550,582,621,625,632,742,743,780,781,782$, $791,792,943,944,945,1018,1020,1021,1339,1340,1444,1682$, $1731,1745,1746,1749,1771$

Dockum Group: 446

Douglas Creek Member of Green River Formation: 7, 211, 302, 342, 352, $780,781,782,886,1020,1021,1444$

Drill-stem tests: $780,1599,1771$ 
Duchesne River Formation: 791, 792

Dyer Dolomite Member of Chaffee Formation: 621

Eagle Valley Evaporite or Formation: 622, 909, 912, 1094, 1371, 1450, 1707

Elbert Formation: 622

Entrada Sandstone: 116, 541, 580, 581, 792

Eocene Series: $398,460,632,683,689,883,886,889,893,944,1067$, $1244,1250,1523,1525$

Evacuation Creek Member of Green River Formation: 352

Fort Union Formation: 632

Garden Gulch Member of Green River Formation: 7, 211, 352, 886, 1020, 1444,1590

Geologic sections: $7,211,307,308,398,541,582,618,621,625,742$, $743,780,781,782,824,942,943,1018,1291,1339,1379,1404$, $1405,1590,1597,1682,1742,1745,1749,1770$

Geophysical logs: $7,211,307,308,398,541,582,618,621,625,742$, $743,780,781,782,824,942,943,1018,1291,1339,1379,1404$, $1405,1590,1592,1682,1742,1745,1749,1770$

Gilman Sandstone: 621

Glacial deposits: 791

Glen Canyon Group: $116,580,581,582,792$

Green River Formation: 7, 31, 116, 211, 253, 255, 257, 282, 302, 307, $308,342,352,392,398,460,470,550,683,689,742,743,779$, $780,781,782,792,824,886,944,957,1020,1021,1067,1106$, $1148,1196,1250,1321,1323,1339,1379,1404,1405,1444,1523$, $1525,1526,1590,1628,1696,1742,1745,1748,1749,1765,1771$, 1846

Hermosa Formation: 622

Honaker Trail Formation: 622

Ignacio Quartzite: 622

Iles Formation: $405,632,1371,1372$

Jurassic System: 135, 580, 581, 582, 1091, 1379, 1731, 1821

Kayenta Formation: 580

Lance Formation: 632

Leadville Limestone: $116,340,621,622,742,743,824$

Lewis Shale: 632

Lithologic logs: 7, 308, 352, 398, 621, 625, 780, 792, 1339, 1682

Lodore Formation: 622

Madison Limestone: $621,622,792$

Mancos Shale: $135,282,469,580,581,582,632,792,932,949,1220$

Maroon Formation: $622,909,912,1450,1707$

Mesaverde Group: $116,171,282,405,580,581,582,632,649,792,889$, $893,901,949,1041,1229,1230,1234,1339,1846$

Mesozoic Erathem: $580,581,582,1078,1340,1597,1599,1750,1751$

Minturn Formation: $144,622,832,1450,1707$

Mississippian System: $340,618,619,620,621,1018,1091,1731,1784$

Moenkopi Formation: $541,580,581,582,792$

Molas Formation: 622

Morgan Formation: 622, 792, 1707

Morrison Formation: $541,580,581,582,729,792$

Navajo Sandstone: 580

Ohio Creek Formation: 901, 1680, 1846

Ordovician System: 618,619,620, 1018, 1784

Ouray Limestone: 622 
Paleozoic Erathem: 228, 618, 619, 620, 622, 909, 1018, 1078, 1340, 1379, $1597,1599,1784$

Paonia Shale Member of Mesaverde Formation: 405

Parachute Creek Member of Green River Formation: 7, 211, 307, 342, 352, $392,398,780,781,782,886,1020,1021,1379,1404,1405,1444$, $1590,1745,1748,1749,1771$

Paradox Member of Hermosa Formation: 622

Park City Formation: 622, 792

Pennsylvanian System: 124, 144, 618, 619, 620, 622, 832, 909, 912, 956, $1018,1091,1379,1450,1707,1731,1784$

Permian System: $618,619,620,622,912,956,1018,1091,1371,1379$, $1707,1731,1784$

Pierre Shale: 949

Pinkerton Trail Formation: 622

Precambrian Erathem: 1018, 1091, 1340, 1379, 1731

Price River Formation: 405

Quaternary System: 282, 1091, 1339, 1379, 1731

Rico Formation: 622

Rollins Sandstone Member of Mesaverde Formation: 405

Salt Wash Sandstone Member of Morrison Formation: 729

San Rafael Group: 582, 1821

Sawatch Sandstone Formation: 622, 1784

Sego Sandstone: 405, 1229

Silurian System: 619,1018

State Bridge Formation: 622, 909

Summerville Formation: 580

Sundance Formation: 580

Tertiary System: $398,632,689,877,879,880,881,889,892,893,899$, $945,1065,1091,1158,1250,1379,1597,1599,1680,1696,1731$

Triassic System: 446, 580, 581, 582, 1091, 1379, 1731

Uinta Formation: $7,211,253,392,398,689,742,743,782,791,792$, $824,945,1020,1106,1148,1250,1339,1379,1404,1405,1444$, $1590,1742,1745,1771$

Uinta Mountain Group: 622, 792

Upper Cretaceous Series: $171,405,877,879,880,881,890,892,893$, $901,1229,1230,1234,1371,1372,1543,1680,1846$

Upper Jurassic Series: 729

Upper Triassic Series: 446

Valley-fill deposits: 116,632

Wasatch Formation: $7,211,308,632,779,782,792,1020,1220,1339$, $1444,1680,1846$

Water levels: $7,342,343,344,352,442,541,550,580,621,625,632$, $781,782,791,792,1091,1124,1339,1340,1682,1745,1746,1751$, 1771

Water-quality analyses: $7,64,211,282,307,308,342,343,344,352$, $392,442,528,541,550,621,632,742,743,780,781,782,791$, $792,943,944,1020,1021,1339,1444,1682,1731,1745,1746,1749$, 1771

Weber Sandstone: $124,541,622,791,792,909,1225,1450,1707$

Williams Fork Formation: 171, 405, 632, 1371, 1372, 1680

Wingate Sandstone: 116,580

Rio Grande County: $64,323,509,528,742,743,824,1091,1124,1236,1283$, $1291,1312,1340,1379,1432,1563,1564$

Alluvium, undifferentiated: $742,743,824$ 


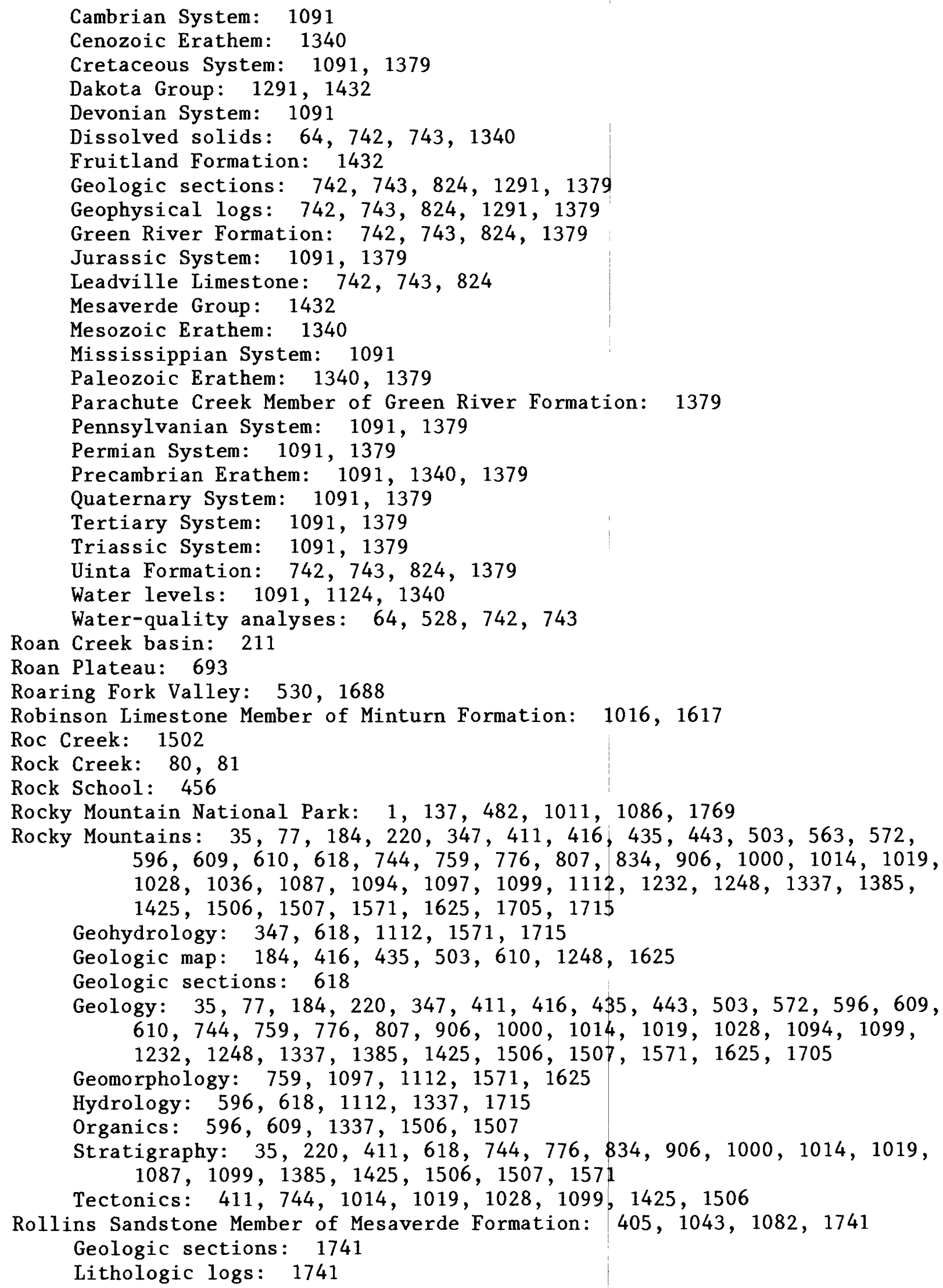


Rough Gulch: 679

Round Bottom: 862, 863

Round Mountain: 160,573

Routt County: $45,62,64,72,116,149,154,165,166,170,171,222,228$, $232,238,282,284,289,325,328,350,354,366,390,439,442$, $507,528,543,544,580,581,582,594,618,619,620,621,622$, $623,632,647,655,699,742,743,750,787,793,823,824,864$, $865,938,949,962,973,974,984,995,1018,1028,1051,1065$, $1084,1091,1094,1124,1126,1128,1143,1170,1291,1294,1312$, $1340,1349,1379,1420,1422,1437,1446,1472,1476,1481,1482$, $1497,1506,1507,1527,1528,1552,1553,1555,1567,1569,1572$, $1597,1599,1617,1630,1642,1643,1653,1654,1718,1731,1750$, $1751,1784,1793,1794,1798,1801,1810,1822$

Alluvium, undifferentiated: $149,350,354,621,632,699,742,743,824$ Aquifer tests: 621,1572

Belden Formation: 622

Browns Park Formation: 149, 354, 632, 1065

Cambrian System: 618,619,620, 1018, 1091, 1784

Carmel Formation: 580,581

Cedar Mountain Formation: $580,581,582$

Cenozoic Erathem: 1340

Chaffee Formation: 621,699

Chinle Formation: $580,581,582$

Cretaceous System: $580,581,582,787,949,973,1028,1091,1379,1420$, $1481,1507,1731$

Curtis Formation: 580

Cutler Formation: 622

Dakota Group: $116,580,581,582,699,1291$

Devonian System: 618,619,620,621, 1018, 1091, 1784

Dissolved solids: $64,116,149,282,354,442,582,621,632,699,742$, $743,1018,1340,1572,1731,1794$

Drill-stem tests: 1599

Dyer Dolomite Member of Chaffee Formation: 621, 699

Eagle Valley Evaporite or Formation: 622, 1094

Elbert Formation: 622

Entrada Sandstone: $116,580,581,699$

Eocene Series: 632, 1422

Fort Union Formation: 149, 632, 787

Fox Hills Sandstone: 787

Geologic sections: $350,582,618,621,742,743,824,1018,1291,1379$, 1572

Geophysical logs: $350,582,618,621,742,743,824,1018,1291,1379$, 1572

Gilman Sandstone: 621

Glen Canyon Group: $116,580,581,582$

Green River Formation: 116, 282, 742, 743, 824, 1379, 1422

Hermosa Formation: 622

Honaker Trail Formation: 622

Ignacio Quartzite: 622

Iles Formation: $149,632,1446,1506,1507,1572$

Jurassic System: 580, 581, 582, 1091, 1379, 1497, 1731, 1822

Kayenta Formation: 580

Lance Formation: $149,354,632,787$

Leadville Limestone: $116,621,622,699,742,743,824$ 
Lewis Shale: $149,354,632,1572,1718$

Lithologic logs: 621

Lodore Formation: 622

Madison Limestone: 621,622

Mancos Shale: 149, 282, 354, 580,581, 582, 632, 949, 1481

Manitou Formation: 699

Maroon Formation: 622, 699

Mesaverde Group: $116,149,171,282,354,580,581,582,594,632,865$, $938,1507,1572$

Mesozoic Erathem: 580, 581, 582, 1340, 1597, 1599, 1750, 1751

Minturn Formation: $622,699,1617$

Mississippian System: 618, 619,620,621, 1018, 1091, 1731, 1784

Moenkopi Formation: 580, 581, 582

Molas Formation: 622

Morgan Formation: 622

Morrison Formation: 580, 581, 582, 699

Navajo Sandstone: 580

Ordovician System: $618,619,620,1018,1784$

Ouray Limestone: 622

Paleozoic Erathem: 228, 618, 619, 620, 622, 1018, 1340, 1379, 1597, 1599,1784

Parachute Creek Member of Green River Formation: 1379

Paradox Member of Hermosa Formation: 622

Park City Formation: 622

Parting Quartzite Member of Chaffee Formation: 699

Pennsylvanian System: 618, 619,620,622, 699, 1018, 1091, 1379, 1731, 1784

Permian System: $618,619,620,622,1018,1091,1379,1481,1497,1731$, 1784

Pierre Shale: 949

Pinkerton Trail Formation: 622

Precambrian Erathem: 699, 1018, 1091, 1340, 1379, 1731

Quaternary System: 282, 1091, 1379, 1731

Rico Formation: 622

Robinson Limestone Member of Minturn Formation: 1617

San Rafael Group: 582, 1822

Sawatch Sandstone Formation: 622, 699, 1784

Silurian System: 619,1018

State Bridge Formation: 622

Summerville Formation: 580

Sundance Formation: 580

Terrace deposits: 699

Tertiary System: 45, 632, 787, 793, 1065, 1091, 1379, 1422, 1597, 1599, 1731

Triassic System: 580, 581, 582, 1091, 1379, 1497, 173i

Trout Creek Sandstone Member of Iles Formation: 1446, 1506, 1507, 1572

Twentymile Sandstone Member of Williams Fork Formation: 1446, 1506, 1507,1572

Uinta Formation: $742,743,824,1379$

Uinta Mountain Group: 622

Upper Cretaceous Series: 45, 171, 594, 787, 865, 949, 962, 1420, 1506, 1507,1718

Valley-fill deposits: 116,632 
Wasatch Formation: $149,632,787,1422$

Water levels: $350,354,442,580,621,632,1091,1124,1340,1446,1751$ Water-quality analyses: $64,149,282,284,354,442,528,621,632,699$, $742,743,1572,1731,1794$

Weber Sandstone: 622,1481

Williams Fork Formation: 149, 171, 632, 1446, 1507, 1572

Wingate Sandstone: 116,580

Routt Hot Springs: 1294

Royal Mountain: 1115

Rudolph Hill: 1259

Ruedi: 577

Ruedi Dam: 873, 1227

Ruedi Reservoir: 873, 1227

Ruffner: 733,734

Runberg: 1087

Sage Plain: $810,811,812,813,814,1803$

Saguache County: $10,11,64,116,143,173,284,323,329,527,528,580$, $581,582,619,620,622,626,641,742,743,745,747,748,824$, $1018,1091,1093,1120,1124,1142,1259,1260,1261,1262,1263$, $1267,1268,1269,1282,1291,1312,1340,1353,1360,1377,1379$, $1439,1566,1597,1599,1655,1731,1750,1751,1784$

Alluvium, undifferentiated: $742,743,824$

Belden Formation: 622

Cambrian System: 619,620, 1018, 1091, 1784

Carmel Formation: 580,581

Cedar Mountain Formation: $580,581,582$

Cenozoic Erathem: 1340

Chaffee Formation: 1439

Chinle Formation: $580,581,582$

Cretaceous System: 580, 581, 582, 1091, 1379, 1731

Curtis Formation: 580

Cutler Formation: 622

Dakota Group: $116,580,581,582,1291$

Devonian System: 619,620, 1018, 1091, 1784

Dissolved solids: $64,116,582,742,743,1018,1340,1731$

Drill-stem tests: 1599

Eagle Valley Evaporite or Formation: 622

Elbert Formation: 622

Entrada Sandstone: $116,580,581$

Geologic sections: $582,742,743,824,1018,1291,1379$

Geophysical logs: 582, 742, 743, 824, 1018, 1291, 1379

Glen Canyon Group: $116,580,581,582$

Green River Formation: 116, 742, 743, 824, 1379

Hermosa Formation: 622

Honaker Trail Formation: 622

Ignacio Quartzite: 622

Jurassic System: 580, 581, 582, 1091, 1379, 1731

Kayenta Formation: 580

Leadville Limestone: $116,622,742,743,824,1439$

Lodore Formation: 622

Madison Limestone: 622

Mancos Shale: 580, 581, 582

Maroon Formation: 622

Mesaverde Group: $116,580,581,582$ 
Mesozoic Erathem: 580, 581, 582, 1340, 159\&, 1599, 1750, 1751

Minturn Formation: 622

Mississippian System: 619,620, 1018, 1091, 1439, 1731, 1784

Moenkopi Formation: $580,581,582$

Molas Formation: 622

Morgan Formation: 622

Morrison Formation: $580,581,582$

Navajo Sandstone: 580

Ordovician System: 619,620, 1018, 1784

Ouray Limestone: 622

Paleozoic Erathem: 619, 620, 622, 1018, 1340, 1379, 1597, 1599, 1784

Parachute Creek Member of Green River Formation: 1379

Paradox Member of Hermosa Formation: 622

Park City Formation: 622

Pennsylvanian System: 619, 620,622, 1018, 1091, 1379, 1731, 1784

Permian System: 619, 620,622, 1018, 1091, 1379, 1731, 1784

Pinkerton Trail Formation: 622

Precambrian Erathem: 10, 11, 1018, 1091, 1340, 1379, 1731

Quaternary System: 1091, 1379, 1731

Rico Formation: 622

San Rafael Group: 582

Sawatch Sandstone Formation: 622, 1784

Silurian System: 619,1018

State Bridge Formation: 622

Summerville Formation: 580

Sundance Formation: 580

Tertiary System: 1091, 1120, 1379, 1597, 1599, 1731

Triassic System: $580,581,582,1091,1379,1731$

Uinta Formation: $742,743,824,1379$

Uinta Mountain Group: 622

Upper Devonian Series: 1439

Valley-fill deposits: 116

Water levels: $580,1091,1124,1340,1751$

Water-quality analyses: $64,284,528,742,743,1731$

Weber Sandstone: 622

Wingate Sandstone: 116,580

Sa1t: $53,277,526,729,772,793,861,1116,1772,1779$

Salt Wash Sandstone Member of Morrison Formation: 112, 729, 1089, 1304, 1512, 1658

San Arroyo: 1274

San Jose Formation: $150,151,157,212,535,826$

Dissolved solids: $157,212,826$

Geologic sections: 157

Lithologic logs: 150,151

Water levels: 157,826

Water-quality analyses: $157,212,826$

San Juan basin: $24,30,40,82,131,134,288,300,337,346,349,361,362$, $389,393,400,404,421,533,534,535,536,537,538,539567,584$, $585,653,778,815,820,853,922,929,966,1003,1071,1072,1101$, $1159,1166,1176,1177,1182,1217,1231,1300,1302,1306,1377$, $1378,1432,1508,1570,1601,1602,1615,1632,1787,1817$

Dissolved solids: 922

Drill-stem tests: 922

Geohydrology: $346,361,362,393,400,1071,1072$ 
Geologic map: 349,1602

Geologic sections: $393,585,922,1071$

Geology: $24,30,40,82,131,134,288,300,337,349,400,404,533$, $534,535,536,538,539,567,820,853,922,1072,1159,1166,1182$, $1217,1231,1300,1306,1432,1508,1570,1602,1632,1787,1817$

Geomorphology: $40,389,653,820,853,966,1300$

Hydrology: $346,361,362,400,1071,1072,1432,1787,1817$

Model: $361,400,585,1377$

Organics: $288,404,534,536,539,922,1432,1632$

Stratigraphy: $24,30,288,337,533,534,535,536,537,538,539,653$, $815,966,1101,1166,1176,1182,1231,1300,1302,1306,1508$, $1601,1632,1787$

Tectonics : $24,337,389,535,929,1302,1508,1570$

Water levels: 362

Water-quality analyses: 393,922

San Juan County: 25, 26, 30, 36, 37, 39, 57, 64, 78, 190, 198, 201, 202, 203, $230,298,323,331,341,346,370,375,376,379,389,477,517$, $528,529,532,535,537,539,564,580,581,582,584,588,619$, $620,622,635,636,653,667,722,742,743,778,784,824,853$, $927,931,966,978,994,1018,1057,1058,1059,1060,1061,1063$, $1072,1077,1091,1103,1124,1127,1152,1159,1176,1177,1185$, $1189,1219,1228,1291,1300,1306,1312,1315,1334,1340,1357$, $1358,1363,1378,1379,1432,1441,1456,1460,1462,1484,1508$, $1538,1539,1559,1568,1597,1599,1694,1695,1701,1705,1708$, $1731,1736,1750,1751,1761,1762,1763,1784,1787,1795,1800$, $1802,1817,1836$

Alluvium, undifferentiated: $742,743,824$

Animas Formation: 535

Belden Formation: 622

Burro Canyon Formation: 30

Cambrian System: 619, 620, 722, 1018, 1091, 1784

Carmel Formation: 580,581

Cedar Mountain Formation: $580,581,582$

Cenozoic Erathem: 1340

Chinle Formation: $580,581,582$

Cliff House Sandstone: 532

Cretaceous System: 30, 537, 539, 580, 581, 582, 1091, 1300, 1379, 1508, 1731,1836

Curtis Formation: 580

Cutler Formation: 37,622

Dakota Group: $30,580,581,582,966,1291,1432$

Devonian System: 619, 620, 1018, 1091, 1784

Dissolved solids: $64,582,722,742,743,1018,1340,1731$

Drill-stem tests: 1599

Eagle Valley Evaporite or Formation: 622

Elbert Formation: 622

Entrada Sandstone: 580,581

Fruitland Formation: 537, 539, 1176, 1432

Geologic sections: $582,722,742,743,824,1018,1291,1379$

Geophysical logs: $582,722,742,743,824,1018,1291,1379$

Glen Canyon Group: $580,581,582$

Green River Formation: 742, 743, 824, 1379

Hermosa Formation: 622, 722, 853

Honaker Trail Formation: $37,622,722$ 
Ignacio Quartzite: 622

Jurassic System: 580, 581, 582, 653, 1091, 1379, 1731

Kayenta Formation: 580

Kirtland Shale: 537, 1176

Leadville Limestone: $25,26,37,622,742,743,824$

Lewis Shale: 537, 539, 1176, 1441

Lodore Formation: 622

Lower Permian Series: 230

Madison Limestone: 622

Mancos Shale: 580, 581, 582, 1176

Maroon Formation: 622

Menefee Formation: 1176

Mesaverde Group: 580, 581, 582, 778, 1432

Mesozoic Erathem: 580, 581, 582, 1077, 1340, 1597, 1599, 1750, 1751

Minturn Formation: 622

Mississippian System: 25, 619, 620, 722, 1018, 1091, 1731, 1784

Moenkopi Formation: $580,581,582$

Molas Formation: $37,622,853,1159$

Morgan Formation: 622

Morrison Formation: $580,581,582,1787$

Nacimiento Formation: 535

Navajo Sandstone: 580

Niobrara Formation: 1176

Ordovician System: 619,620, 1018, 1784

Ouray Limestone: 622

Paleocene Series: 537,1508

Paleozoic Erathem: 37, 298, 619, 620, 622, 1018, 1340, 1379, 1597, 1599, 1784

Parachute Creek Member of Green River Formation: 1379

Paradox Member of Hermosa Formation: 622, 722

Park City Formation: 622

Pennsylvanian System: 39, 619, 620, 622, 636, 722, 1018, 1091, 1127, $1379,1538,1539,1731,1784$

Permian System: $619,620,622,722,1018,1091,1379,1731,1784$

Pictured Cliffs Sandstone: 532, 537, 539, 1176, 1441

Pinkerton Trail Formation: 37, 622, 722

Point Lookout Sandstone: 1176

Precambrian Erathem: $37,57,1018,1091,1340,1379,1731$

Quaternary System: 635, 1091, 1379, 1731

Rico Formation: 622, 853

San Jose Formation: 535

San Rafael Group: 582

Sawatch Sandstone Formation: 622, 1784

Silurian System: 619, 1018

State Bridge Formation: 622

Summerville Formation: 580

Sundance Formation: 580

Tertiary System: $535,1077,1091,1379,1508,1597,1599,1731$

Triassic System: $580,581,582,1091,1379,1731$

Uinta Formation: $742,743,824,1379$

Uinta Mountain Group: 622

Upper Cretaceous Series: $389,537,1176,1441,1508$

Water levels: $580,1091,1124,1340,1751$ 
Water-quality analyses: $64,528,722,742,743,1701,1731$

Weber Sandstone: 622

Westwater Canyon Sandstone Member of Morrison Formation: 1787

Wingate Sandstone: 580

San Juan Mountains: 25, 36, 37, 38, 39, 106, 107, 113, 152, 196, 199, 201, $202,203,295,296,297,341,561,564,636,833,931,967,1023$, $1024,1063,1127,1189,1315,1539,1557,1564,1565,1568,1726$, $1753,1755,1815,1830$

Geohydrology: 296

Geologic map: 152, 199, 201, 202, 833, 967, 1024, 1063, 1564

Geology: 36, 37, 106, 107, 113, 152, 196, 199, 203, 295, 341, 561, 636, $833,931,967,1023,1063,1189,1315,1557,1564,1565,1568,1755$, 1815,1830

Hydrology: 295, 296

Model: 297

Stratigraphy: $25,36,37,38,39,107,113,341,561,833,1127,1539$, 1726,1753

Tectonics: $36,39,931,1127,1539,1753$

San Miguel County: 4, 6, 53, 64, 107, 153, 195, 204, 205, 206, 207, 208, 209, $230,259,260,263,267,268,269,270,271,272,273,321,323$, $327,329,380,477,525,528,580,581,582,588,619,620,622$, $635,641,656,665,667,682,691,722,742,743,775,824,960$, $1018,1060,1061,1091,1124,1185,1219,1228,1245,1249,1252$, $1291,1311,1312,1340,1379,1432,1462,1485,1486,1487,1489$, $1490,1491,1509,1549,1560,1575,1597,1599,1604,1605,1655$, $1657,1697,1716,1717,1731,1736,1750,1751,1761,1762,1763$, $1766,1784,1802,1807$

Alluvium, undifferentiated: $742,743,824,1766$

Belden Formation: 622

Burro Canyon Formation: 1509, 1605

Cambrian System: 6, 619,620, 722, 1018, 1091, 1766, 1784

Carmel Formation: 580, 581, 1605

Cedar Mountain Formation: $580,581,582$

Cenozoic Erathem: 1340

Chinle Formation: $580,581,582,1605$

Cretaceous System: 6, 580, 581, 582, 1091, 1379, 1731, 1766

Curtis Formation: 580

Cutler Formation: 622, 775

Dakota Group: $580,581,582,1291,1432,1509,1605$

Devonian System: $6,619,620,1018,1091,1766,1784$

Dissolved solids: $4,64,582,722,742,743,961,1018,1311,1340$, 1731,1766

Dolores Formation: 107

Drill-stem tests: 1599,1766

Eagle Valley Evaporite or Formation: 622

Elbert Formation: 6, 622, 1766

Entrada Sandstone: 580, 581, 1549, 1605

Fruitland Formation: 1432

Geologic sections: $582,722,742,743,775,824,960,1018,1291,1379$, 1605

Geophysical logs: 582, 722, 742, 743, 775, 824,960,1018, 1291, 1379, 1605

Glen Canyon Group: $580,581,582$

Green River Formation: 742, 743, 824, 1379 
Hermosa Formation: 622, 722, 775, 1766

Honaker Trail Formation: 622, 722, 775

Ignacio Quartzite: 622

Junction Creek Sandstone: 1605

Jurassic System: 6, 580, 581, 582, 1091, 1245, 1249, 1252, 1379, 1549, $1657,1731,1766$

Kayenta Formation: 580,1605

Leadville Limestone: 6, 622, 742, 743, 824, 1766

Lodore Formation: 622

Lower Permian Series: 230

Madison Limestone: 622

Mancos Shale: 580, 581, 582, 1605

Maroon Formation: 622

Mesaverde Group: $580,581,582,1432$

Mesozoic Erathem: 580, 581, 582, 1340, 1597, 1599, 1750, 1751

Middle Jurassic Series: 1249, 1252, 1549

Minturn Formation: 622

Mississippian System: 6, 619,620,722, 1018, 1091, 1731, 1766, 1784

Moenkopi Formation: $580,581,582$

Molas Formation: 622, 775

Morgan Formation: 622

Morrison Formation: $580,581,582,1252,1311,1605$

Navajo Sandstone: 580,1605

Ordovician System: $619,620,1018,1784$

Ouray Limestone: $6,622,1766$

Paleozoic Erathem: 619, 620,622, 1018, 1340, 1379, 1597, 1599, 1784

Parachute Creek Member of Green River Formation: 1379

Paradox Member of Hermosa Formation: 622, 722, 775, 1766

Park City Formation: 622

Pennsylvanian System: 6, 619, 620, 622, 722, 1018, 1091, 1379, 1731, 1766,1784

Permian System: 6, 619,620, 622, 722, 1018, 1091, 1379, 1731, 1766, 1784

Pinkerton Trail Formation: $622,722,775$

Precambrian Erathem: 6, 1018, 1091, 1340, 1379, 1731, 1766

Quaternary System: 6, 635, 1091, 1379, 1731

Rico Formation: 622

San Rafael Group: 582, 1249, 1252

Sawatch Sandstone Formation: 622, 1784

Silurian System: 619, 1018

State Bridge Formation: 622

Summerville Formation: 580

Sundance Formation: 580

Tertiary System: 6,1091, 1379, 1597, 1599, 1731, 1766

Triassic System: $6,580,581,582,1091,1379,1731,1766$

Uinta Formation: $742,743,824,1379$

Uinta Mountain Group: 622

Wanakah Formation: 1549,1605

Water levels: 4, 580, 1091, 1124, 1311, 1340, 1751, 1766

Water-quality analyses: $4,64,528,722,742,743,960,1311,1731,1766$

Weber Sandstone: 622

Wingate Sandstone: 580,1605 
San Miguel River basin: 4, 6

San Rafael Group: $582,836,1032,1249,1252,1581,1818,1819,1820,1821$, 1822,1823

Aquifer tests: $836,1032,1581$

Dissolved solids: $582,836,1032,1581$

Geologic sections: 582, 1032

Hydraulic conductivity: 582, 836, 1032

Lithologic logs: 836,1032

Porosity: 1032

Storage coefficient or specific yield: 582, 836, 1032

Transmissivity: $582,836,1032,1581$

Water levels: $836,1032,1581$

Water-quality analyses: $836,1032,1581$

Sand Wash basin: 45, 171, 220, 222, 223, 787, 834, 964, 1028, 1421, 1422, 1506,1507

Geology: $45,171,220,222,223,787,1028,1421,1422,1506,1507$

Geomorphology: 45

Organics: 1506,1507

Stratigraphy: $45,171,220,787,834,1421,1422,1506,1507$

Tectonics: 1028,1506

Sangre De Cristo Formation: 1019

Sargents: 1353

Sawatch Anticline: 81

Sawatch Range: 385, 1053, 1087, 1524, 1545

Sawatch Sandstone: $622,630,699,1425,1784$

Dissolved solids: 630,699

Geophysical logs: 1784

Hydraulic conductivity: 622, 630

Porosity: 622, 1784

Transmissivity: 630

Water levels: 630

Water-quality analyses: 630,699

Sawmill Mountain: 1369,1371

Sawtooth Mountain: 1267

Scrivner Butte: 1417

Sedimentology: 2,163, 775, 1302, 1439, 1448, 1449, 1780, 1811, 1833

Segar Mountain: 1243

Sego Canyon: 571

Sego Sandstone: 405, 412, 1229

Seismicity: $627,1354,1462,1707,1782$

Selenium: 1516

Sentinel Peak: 489, 495

Shadow Mountain Recreation Area: 1769

Silurian System: 547, 619, 1018

Dissolved solids: 1018

Geologic sections: 1018

Hydraulic conductivity: 619

Porosity: 619

Transmissivity: 619

Silver Cliff: 1361

Silver Plume Granite: 1457

Silverton: $78,198,370,376,569,1059,1063,1127,1357,1358,1694,1695$

Skull Creek: 215 
Skylab: 1004

Slater Dome: 1126

Slater Park: 1718

Sleeping Ute Mountain: 617

Slick Rock: 1245, 1252, 1484, 1485, 1486, 1487, 1489, 1490, 1491, 1509, 1657

Smizer Gulch: 678

Smuggler Mine: 981

Snowmass Mountain: $1207,1683,1686,1687$

Sodium: $114,128,604$

Sodium Hypochlorite: 114

Soils: 106, 107, 318, 635, 1026, 1029, 1087, 1185, 1573, 1829

Solute transport: 1495,1732

Solution mining: 572

Somerset: 397,1241

Somerset coal field: 397

South Canyon Creek Dolomite Member of State Bridge Formation: 73

South Ophir district: 1228

Southern Ute Indian Reservation: 29, 151, 539, 826

Spar City: 1557, 1561

Spoils: 1579

Spring Hill Creek: 1269

Springs: $4,5,7,59,66,73,74,120,148,158,159,183,211,235,284$, $289,320,334,408,465,468,528,552,598,617,740,832,839,841$, $845,871,975,985,995,1051,1076,1079,1122,1149,1293,1294,1420$, $1493,1503,1548,1587,1659,1728,1734,1746,1789,1810,1849$

Square S Ranch: 453, 693

St. Louis Peak Roadless Area: 524

Star Mine: 605

State Bridge: 1453

State Bridge Formation: 148, 411, 575, 622, 631, 909, 910

Dissolved solids: 148,631

Hydraulic conductivity: 622

Porosity: 622

- Water-quality analyses: 148,631

Steamboat Springs: 289, 995, 1051, 1810

Steward Creek: 1516

Strawberry Lake: 1457

Strontium: 1517

Subsidence: $157,538,1543$

Sulfides: 114,440

Summerville Formation: 580, 585, 785, 836, 1032

Aquifer tests: 836, 1032

Dissolved solids: 836,1032

Geologic sections: 585, 1032

Hydraulic conductivity: 580, 836, 1032

Lithologic logs: 836, 1032

Porosity: 580,1032

Storage coefficient or specific yield: 836,1032

Transmissivity: 836,1032

Water levels: $580,836,1032$

Water-quality analyses: 836, 1032 
Summit County: $54,58,64,89,90,116,185,186,282,284,322,325,371$, $418,446,511,524,528,580,581,582,618,619,620,621,622$, $697,742,743,786,824,950,986,987,1018,1047,1091,1115$, $1124,1132,1215,1216,1291,1312,1340,1345,1355,1359,1379$, $1402,1403,1443,1477,1513,1514,1586,1597,1599,1635,1636$, $1638,1639,1640,1652,1653,1654,1670,1699,1715,1731,1750$, $1751,1756,1782,1783,1784$

Alluvium, undifferentiated: $621,742,743,824,1699$

Aquifer tests: 621

Belden Formation: 622

Cambrian System: 618, 619,620, 1018, 1091, 1784

Carmel Formation: 580,581

Cedar Mountain Formation: 580, 581, 582

Cenozoic Erathem: 1340

Chaffee Formation: 621

Chinle Formation: 446, 580, 581, 582

Coalmont Formation: 1699

Cretaceous System: 580, 581, 582, 1091, 1379, 1731, 1756

Curtis Formation: 580

Cutler Formation: 622

Dakota Group: $116,580,581,582,1291,1756$

Devonian System: $618,619,620,621,1018,1091,1784$

Dissolved solids: $64,116,282,582,621,742,743,1018,1340,1699$, 1731

Dockum Group: 446

Drill-stem tests: 1599

Dyer Dolomite Member of Chaffee Formation: 621

Eagle Valley Evaporite or Formation: 622

Elbert Formation: 622

Entrada Sandstone: $116,580,581$

Geologic sections: $582,618,621,742,743,824,1018,1291,1379$

Geophysical logs: $582,618,621,742,743,824,1018,1291,1379$

Gilman Sandstone: 621

Glen Canyon Group: 116, 580, 581, 582

Green River Formation: 116, 282, 742, 743, 824, 1379

Hermosa Formation: 622

Honaker Trail Formation: 622

Ignacio Quartzite: 622

Jurassic System: $580,581,582,1091,1379,1731$

Kayenta Formation: 580

Leadville Limestone: $116,621,622,742,743,824$

Lithologic logs: 621, 1699

Lodore Formation: 622

Madison Limestone: 621,622

Mancos Shale: 282, 580, 581, 582

Maroon Formation: 622

Mesaverde Group: $116,282,580,581, .582$

Mesozoic Erathem: 580,581, 582, 1340, 1597, 1599, 1750, 1751

Minturn Formation: 622

Mississippian System: 618, 619,620,621, 1018, 1091, 1731, 1784

Moenkopi Formation: $580,581,582$

Molas Formation: 622

Morgan Formation: 622

Morrison Formation: $580,581,582$ 
Navajo Sandstone: 580

Ordovician System: $618,619,620,1018,1784$

Ouray Limestone: 622

Paleozoic Erathem: 618, 619, 620, 622, 1018, 1340, 1379, 1597, 1599, 1784

Parachute Creek Member of Green River Formation: 1379

Paradox Member of Hermosa Formation: 622

Park City Formation: 622

Pennsylvanian System: 618, 619,620,622, 1018, 1091, 1379, 1638, 1731, 1784

Permian System: 618, 619,620,622, 1018, 1091, 1379, 1731, 1784

Pinkerton Trail Formation: 622

Precambrian Erathem: 1018, 1091, 1340, 1379, 1731

Quaternary System: 282, 1091, 1379, 1731, 1782, 1783

Rico Formation: 622

San Rafael Group: 582

Sawatch Sandstone Formation: 622, 1784

Silurian System: 619,1018

State Bridge Formation: 622

Summerville Formation: 580

Sundance Formation: 580

Tertiary System: 1091, 1379, 1597, 1599, 1731

Triassic System: 371, 446, 580, 581, 582, 1091, 1379, 1731

Uinta Formation: $742,743,824,1379$

Uinta Mountain Group: 622

Upper Triassic Series: 446

Valley-fill deposits: 116

Water levels: $580,621,1091,1124,1340,1699,1751$

Water-quality analyses: $64,282,284,528,621,742,743,1699,1731$

Weber Sandstone: 622

Wingate Sandstone: 116,580

Summitville: 1283, 1563, 1564

Sundance Formation: 580,1386

Hydraulic conductivity: 580

Porosity: 580

Water levels: 580

Surface geophysics: 350

Surface water-ground water interactions: $128,218,617,1298,1594,1731$, 1773

Tailings: $925,1341,1342,1826$

Tanks Peak: 715

Taylor Park: 47, 420, 1087, 1240

Tectonics: $24,36,39,41,42,140,183,301,337,389,409,411,535,726$, $744,767,850,889,895,929,931,956,1014,1019,1028,1099,1127$, $1272,1302,1425,1450,1452,1470,1506,1508,1538,1539,1570,1594$, $1600,1649,1707,1753,1805,1813$

Telluride: $195,221,380,656,982,1002,1060,1061,1249,1580,1697$

Temple Canyon: 797

Tenmile district: 511

Tenmile Range: 89

Tennessee Pass: 1636

Terrace deposits: $150,151,157,598,661,699,1032,1581$

Aquifer tests: $598,1032,1581$

Dissolved solids: $157,598,699,1032,1581$ 
Geologic sections: $157,598,1032$

Geophysical logs: 598

Hydraulic conductivity: 1032

Lithologic logs: 150, 151, 598, 1032

Porosity: 1032

Storage coefficient or specific yield: 598,1032

Transmissivity: $598,1032,1581$

Water levels: $157,598,661,1032,1581$

Water-quality analyses: $157,598,699,1032,1581$

Tertiary System: 6, 45, 115, 360, 398, 506, 533, 535, 559, 571, 598, 616, $617,631,632,689,787,793,834,838,877,879,880,881,885$, $889,892,893,896,897,898,899,902,903,944,999,1000,1064$, $1065,1071,1077,1091,1120,1125,1157,1158,1213,1250,1266$, $1379,1421,1422,1495,1498,1508,1522,1592,1597,1599,1680$, $1696,1731,1741,1766,1769$

Aquifer tests: 598

Dissolved solids: $115,360,598,617,631,632,944,1731,1766,1769$

Drill-stem tests: 1599,1766

Geologic sections: $398,598,617,1071,1379,1592,1741$

Geophysical logs: 398, 598

Hydraulic conductivity: 617, 632, 1599

Lithologic logs: $115,360,398,598,617,1741,1769$

Storage coefficient or specific yield: 598

Transmissivity: 598

Water levels: $115,360,598,617,632,1091,1766,1769$

Water-quality analyses: $115,360,598,617,631,632,944,1731,1766$, 1769

Thirteenmile Creek: 1255

Thomasville: 1074,1075

Thompson Creek coal mining area: 935

Thorium: 1277

Thornburgh: 464,1372

Tincup mining district: 637, 958

Todilto Formation: 585, 939, 1386

Geologic sections: 585

Tommy's Draw: 1846

Tommys Draw: 257

Tow Creek: 1798

Towaoc: 617,1329

Toxic waste: 551

Trace elements: 212

Trail Mountain: 840

Transmissivity: $352,355,356,362,618,854,857,858,1071,1700,1752$, 1764,1765

Treasure Mountain Dome: 1206

Triassic System: 6, 35, 106, 371, 423, 445, 446, 580, 581, 582, 598, 617, $1091,1379,1447,1496,1497,1712,1731,1741,1766,1775$

Aquifer tests: 598

Dissolved solids: $582,598,617,1731,1766$

Drill-stem tests: 1766

Geologic sections: $582,598,617,1379,1741$

Geophysical logs: 598

Hydraulic conductivity: $580,581,582,617$

Lithologic logs: $598,617,1741$ 
Porosity: 580,581

Storage coefficient or specific yield: 582,598

Transmissivity: 582,598

Water levels: $580,598,617,1091,1766$

Water-quality analyses: $598,617,1731,1766$

Tritium: 1701

Trout Creek: 1506, 1507

Trout Creek Sandstone Member of Iles Formation: 402, 545, 1081, 1082, 1446, $1506,1507,1572$

Aquifer tests: 1572

Dissolved solids: 1572

Geologic sections: 1572

Hydraulic conductivity: 1572

Storage coefficient or specific yield: 1572

Transmissivity: 1572

Water levels: 1446

Water-quality analyses: 1572

Twentymile Park: 232

Twentymile Sandstone Member of Williams Fork Formation: 402, 1446, 1506, 1507,1572

Aquifer tests: 1572

Dissolved solids: 1572

Geologic sections: 1572

Hydraulic conductivity: 1572

Storage coefficient or specific yield: 1572

Transmissivity: 1572

Water levels: 1446

Water-quality analyses: 1572

Two Creek Anticline: 1028

Uinta Arch: 1425

Uinta basin: $8,33,103,253,255,256,342,343,344,570,779,780,781$, $782,789,790,791,792,889,890,892,895,908,912,941,942$, $943,1020,1021,1022,1181,1337,1339,1448,1468$

Dissolved solids: $342,343,344,780,781,782,790,792,942,943$, $1020,1021,1339$

Drill-stem tests: 780

Geohydrology: $780,782,789,792,941,942,943,1022$

Geologic map: 33

Geologic sections: $780,781,782,942,943,1339$

Geology: $33,103,256,570,779,889,890,892,895,908,912,1020$, $1181,1337,1448,1468$

Geomorphology: 779

Geophysical logs: 780

Hydraulic conductivity: 792

Hydrology: $342,343,780,781,782,789,941,942,943,1020,1022,1337$

Lithologic logs: 780, 792, 1339

Organics: 1022,1337

Porosity: $781,782,792$

Storage coefficient or specific yield: 782

Stratigraphy: $8,103,253,570,890,892,895,908,912,1181,1448$

Tectonics: 889,895

Transmissivity: 780

Water levels: $342,343,344,781,782,791,792,1339$ 
Water-quality analyses: $342,343,344,780,781,782,791,792,942$, $943,1020,1021,1339$

Uinta Formation: $5,7,48,49,159,211,253,301,392,398,403,430,689$, $742,743,782,791,792,824,944,1020,1106,1148,1250,1339$, $1379,1404,1405,1444,1590,1742,1745,1771$

Aquifer tests: 392

Dissolved solids: $5,7,159,211,392,742,743,782,791,792,944$, $1020,1339,1444,1745,1771$

Drill-stem tests: 1771

Geologic sections: 7, 159, 211, 398, 403, 742, 743, 782, 824, 1339, $1379,1404,1405,1590,1742,1745$

Geophysical logs: $398,1745,1771$

Hydraulic conductivity: $792,1106,1148$

Lithologic logs: 7, 398, 792, 1339

Porosity: $782,792,1148$

Storage coefficient or specific yield: $782,1106,1148,1590,1745,1771$

Transmissivity: $7,1106,1771$

Water levels: $5,7,159,403,782,791,792,1339,1745,1771$

Water-quality analyses: $5,7,159,211,392,742,743,782,791,792$, $944,1020,1339,1444,1745,1771$

Uinta Mountain Group: $622,792,1581$

Aquifer tests: 1581

Dissolved solids: 792, 1581

Hydraulic conductivity: 622, 792

Lithologic logs: 792

Porosity: 622,792

Transmissivity: 1581

Water levels: 792,1581

Water-quality analyses: 792,1581

Uinta Mountains: $135,136,422,512,616,709,1088,1107,1305,1328,1392$, $1395,1438,1470,1672,1674,1676,1738,1739$

Unaweep Canyon: $818,1035,1183$

Uncompahgre Arch: 970,1188

Uncompahgre Uplift: $124,409,571,726,776,906,911,1073,1099,1505$, $1570,1614,1707$

Uncompahgre Valley: 360,1147

Upper Cambrian Series: 210, 547, 1296, 1297

Upper Cretaceous Series: 23, 45, 46, 129, 130, 171, 287, 300, 389, 405, 412, $501,506,526,533,534,536,537,538,545,547,570,594,610,634$, $723,770,787,820,865,877,879,880,881,885,890,892,893,896$, $897,898,901,903,948,949,962,999,1000,1005,1006,1007,1008$, $1009,1010,1039,1043,1044,1081,1083,1088,1100,1101,1125,1175$, $1176,1179,1180,1182,1184,1211,1212,1221,1222,1229,1230,1234$, $1284,1371,1372,1420,1423,1441,1506,1507,1508,1542,1543,1680$, $1681,1718,1790,1833,1846$

Upper Devonian Series: 227, 1380, 1439

Upper Jurassic Series: 29, 496, 729, 1301, 1302, 1304, 1632

Upper Mississippian Series: 410

Upper Pennsylvanian Series: 1172

Upper Triassic Series: 445, 446, 547

Uranium: $112,197,244,346,440,525,599,854,857,858,925,1072,1089$, $1154,1155,1190,1271,1272,1277,1311,1341,1371,1383,1465,1602$, $1632,1657,1701,1732,1763,1787,1832$

Uravan: $111,112,276,278,556,859,860,1183,1190,1246,1249,1252$ 
Ute Mountain Indian Reservation: 617,1329

Ute Mountains: $313,486,487,488,490,491,492,804,1747$

Ute Peak: 523

Vail: $247,631,1172,1173,1449$

Valley-fill deposits: $115,116,632,826,1071$

Dissolved solids: $115,116,632,826$

Geologic sections: 1071

Hydraulic conductivity: 632

Lithologic logs: 115

Water levels: $115,632,826$

Water-quality analyses: $115,632,826$

Vanadium: 112, 244, 1190, 1657, 1763

Vasquez Peak Wilderness Study Area: 524

Vasquez Tunnel: 1733

Villa Grove Mine: 626

Volcanism: $36,635,1023,1508$

Wagon Track Ridge: 894

Walsh Knolls: 252

Wanakah Formation: 115, 150, 151, 159, 1386, 1549, 1605

Dissolved solids: 115,159

Geologic sections: 159,1605

Lithologic logs: 115, 150, 151

Water levels: 115,159

Water-quality analyses: 115, 159

Wasatch Formation: 5, 7, 148, 149, 156, 159, 211, 307, 403, 427, 506, 610, $630,632,779,782,787,792,885,900,1000,1020,1220,1339,1421$, $1422,1444,1680,1700,1702,1741,1846$

Dissolved solids: $5,7,148,149,159,211,307,630,632,782,792$, $1020,1339,1444,1700,1702$

Drill-stem tests: 1700,1702

Geologic sections: 7,159,211, 307, 403, 782, 1339, 1702, 1741

Geophysical logs: 307

Hydraulic conductivity: $630,632,792$

Lithologic logs: 7, 792, 1339, 1741

Porosity: 782,792

Storage coefficient or specific yield: 782

Transmissivity: 7,630

Water levels: $5,7,156,159,403,630,632,782,792,1339,1702$

Water-quality analyses: $5,7,148,149,156,159,211,307,630,632$, $782,792,1020,1339,1444,1700,1702$

Washakie basin: $92,138,787,964,1346,1421,1422$

Washboard Rock: 415

Waste disposal: $6,295,296,404,586,742,743,775,1013,1145,1210,1341$, $1342,1391,1573,1579,1587,1736,1802,1827$

Water law: 1661

Water quality: $4,5,7,114,115,128,147,148,149,150,151,157,159$, $211,212,218,282,295,344,362,412,442,463,481,548,572,595$, $603,604,617,624,699,700,742,743,751,753,782,792,852,917$, $945,959,975,1013,1018,1021,1022,1068,1071,1076,1143,1144$, $1145,1151,1152,1210,1339,1340,1516,1518,1519,1533,1550,1587$, $1615,1618,1629,1662,1667,1682,1715,1720,1746,1764,1765,1766$, 1773

Weaver Ridge: 251 
Weber Sandstone: 124, 148, 424, 425, 441, 541, 589, 622, 791, 792, 909, 911, $1225,1450,1480,1481,1581,1707$

Aquifer tests: 1581

Dissolved solids: $148,541,791,792,1581$

Geologic sections: 541

Hydraulic conductivity: 622, 792

Lithologic logs: 792

Porosity: 622, 792

Transmissivity: 1581

Water levels: $541,791,792,1581$

Water-quality analyses: $148,541,791,792,1581$

We11 logging: $115,255,287,501,545,570,609,903,1006,1007,1008,1009$, $1010,1039,1040,1041,1313,1705$

West E1k Mountains: 639

West Fork Lake: 647

West Salt Creek: 526

Westwater: 400, 504, 505, 659

Westwater Canyon: 400

Westwater Canyon Sandstone Member of Morrison Formation: 1166, 1632, 1787

Wetterhorn Peak: 1055

Wheeler basin: 1832

Whiskey Creek: 318

White River City: 1317

White River Dome: 752

White River Plateau: 127, 228, 446, 1043, 1112

White Rock: 1319

Whitewater: 1183

Wildwood Anticline: 1443

Williams Fork: 499, 524, 799, 997, 1349, 1572

Williams Fork Formation: $149,171,402,405,545,632,1044,1082,1083$, $1371,1372,1446,1507,1532,1572,1680,1681$

Aquifer tests: 1572

Dissolved solids: $149,632,1572$

Geologic sections: 1572

Hydraulic conductivity: 632, 1572

Storage coefficient or specific yield: 1572

Transmissivity: 1572

Water levels: 632,1446

Water-quality analyses: 149, 632, 1572

Williams Fork Mountains: 799, 1349, 1572

Williams Park: 1476

Willow Creek Butte: 704

Wilmor Lake: 80

Wilson Creek Dome: 819

Wingate Sandstone: $116,159,580,767,849,850,1032,1605$

Aquifer tests: 1032

Dissolved solids: $116,159,1032$

Geologic sections: 159, 1032, 1605

Hydraulic conductivity: 580, 1032

Lithologic logs: 1032

Porosity: 580, 1032

Storage coefficient or specific yield: 1032

Transmissivity: 1032 


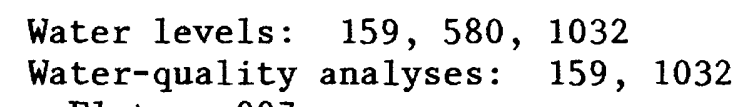

